\author{
Universidade de São Paulo \\ Instituto de Física \\ Instituto de Química \\ Instituto de Biociências \\ Faculdade de Educação
}

\title{
Aprendizado dos conceitos de flor e fruto e sua utilização pelos alunos de Ciências Biológicas do I.B. - USP
}

Ricardo Henrique Pucinelli

Orientador: Prof. Dr. Paulo Takeo Sano

Dissertação de mestrado apresentada ao Instituto de Física, ao Instituto de Química, ao Instituto de Biociências e a Faculdade de Educação da Universidade de São Paulo, para a obtenção do título de Mestre em Ensino de Ciências. 
LOMBADA

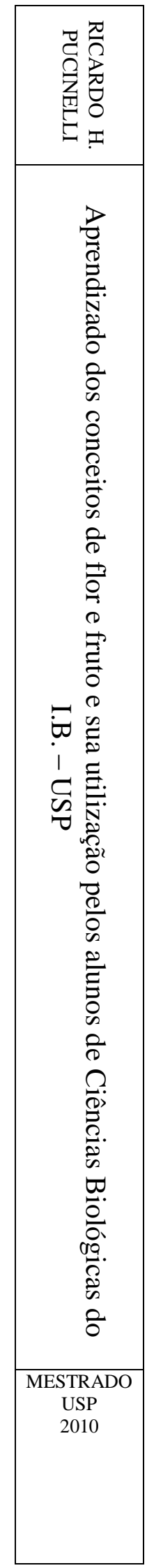


Ricardo Henrique Pucinelli

\section{Aprendizado dos conceitos de flor e fruto e sua utilização pelos alunos de Ciências Biológicas do I.B. - USP}

Dissertação de mestrado apresentada ao Instituto de Física, ao Instituto de Química, ao Instituto de Biociências e a Faculdade de Educação da Universidade de São Paulo, para a obtenção do título de Mestre em Ensino de Ciências.

Área de Concentração: Ensino de Biologia

Orientador: Prof. Dr. Paulo Takeo Sano 
Autorizo a reprodução e divulgação total ou parcial deste trabalho, por qualquer meio convencional ou eletrônico, para fins de estudo e pesquisa, desde que citada a fonte.

FICHA CATALOGRÁFICA

Preparada pelo Serviço de Biblioteca e Informação do Instituto de Física da Universidade de São Paulo

Pucinelli, Ricardo Henrique
Aprendizado dos conceitos de flor e fruto e sua
utilização pelos alunos de Ciências Biológicas do I.B. -
USP. - São Paulo, 2010.
Mestrado (Dissertação) - Universidade de São Paulo.
Instituto de Física, Faculdade de Educação, Instituto de
Química e Instituto de Biociências
Orientador: Prof. Dr. Paulo Takeo Sano
Área de Concentração: Ensino de Biologia
Unitermos: 1. Botânica - Estudo e ensino;
2. Botânica - Aprendizagem; 3. Ensino Superior.
USP/IF/SBI-015/2010




\section{FOLHA DE APROVAÇÃO}

Ricardo Henrique Pucinelli

Aprendizado dos conceitos de flor e fruto e sua utilização pelos alunos de Ciências Biológicas

do I.B. - USP

Dissertação de mestrado apresentada ao Instituto de Física, ao Instituto de Química, ao Instituto de Biociências e a Faculdade de Educação da Universidade de São Paulo, para a obtenção do título de Mestre em Ensino de Ciências.

Área de Concentração: Ensino de Biologia

Aprovada em:

(local e data)

\section{Banca Examinadora}

Prof. Dr.

Instituição:

Assinatura:

Prof. Dr.

Instituição:

Assinatura:

Prof. Dr.

Instituição: Assinatura: 


\section{In Memoriam}

Aos meus saudosos e inesquecíveis amigos Advahir Carmargo Soares e Paulo Soares. 


\section{AGRADECIMENTOS}

\section{Verdades}

Ouve, ó amigo João,

Esta verdade que canto,

Se a verdade causa espanto

Esta causa admiração:

É certo, sem remissão,

E contra isto não há nada,

Que a outra verdade usada

Com rebuços, mais enganos,

É verdade de maganos,

Mas esta é de gente honrada.

Gregório de Mattos Guerra

A vida sempre me possibilitou aprendizados com os quais conquistei muitos títulos e me possibilitou conhecer pessoas que passei a admirar e respeitar, como ícones de sabedoria, dignidade, confiança, singeleza, respeito ao próximo e, acima de tudo, fonte inspiradora de cidadania. Refiro-me aos meus pais, aos meus amigos sinceros, aos Professores, aos Professores Doutores e os meus educandos que compartilham e/ou compartilharam a minha ascensão. A todos a minha imensa gratidão.

Aos meus pais, Neuza Romano Pucinelli e Paulo Pucinelli, queridos que, a sua maneira, mesmo sem compreender muito os porquês das inúmeras noites em claro e dos inúmeros livros sobre a escrivaninha, forneceram-me todo o apoio e o carinho de que precisei.

Aos amigos que compartilham das minhas alegrias, mas que, há alguns anos atrás, souberam compreender as minhas ausências, os meus enganos e, porque não dizer, até mesmo o meu mau-humor! Em especial, ao amigo Fernando Adas pelo carinho e dedicação ao longo destes anos e por ter me auxiliado na reta final do mestrado dando todo o apoio de que precisei. 
Ao Prof. Dr. Paulo Takeo Sano, por todos os conselhos e auxílios prestados ao longo destes anos em que estamos juntos.

Ao Prof. Dr. Alberto Villani, por mostrar com muita singeleza e sapiência o verdadeiro significado da pesquisa qualitativa, durante a disciplina Introdução à Pesquisa em Ensino de Ciências, além de trazer para toda a nossa equipe de estudos a união e a perseverança.

À Profa. Dra. Jesuina Lopes de Almeida Pacca, por me auxiliar a buscar a "Ilha Desconhecida" através da disciplina Construtivismo e o Planejamento da Aprendizagem Significativa.

À Profa. Dra. Anna Maria Pessoa de Carvalho, sempre muito atenciosa e sincera em seus conselhos e orientações.

Ao Prof. Dr. Marcelo Giordan Santos, por todo o incentivo às leituras significativas ao longo da disciplina Perspectivas Socioculturais Para Investigar a Dinâmica das Interações da Sala de Aula de Ciências.

À Profa. Dra. Sonia Godoy Bueno Carvalho Lopes, por nos acompanhar ao longo da disciplina Conceitos Básicos e Conteúdos Curriculares de Biologia no Ensino Médio, fornecendo a todos os mestrandos várias possibilidades de trabalho e crescimento profissional e, em especial, por estar presente em vários momentos importantes da minha vida acadêmica.

À Profa. Dra. Myriam Krasilchik, ao longo da disciplina Metodologia do Ensino Superior, sempre muito atenciosa para com todos, compartilhando a imensidão de conhecimentos e experiências que adquiriu ao longo de tantos anos de dedicação à Universidade de São Paulo.

Ao Prof. Dr. Alberto Augusto Gonçalves de Freitas Castro Ribeiro, pelo seu empenho e dedicação à disciplina Organização do Citoplasma da Célula Animal, mostrando-nos as sutilizas da vida além do que os nossos olhos não conseguem enxergar. 
À Profa. Dra. Deborah Yara Alves Cursino dos Santos, por compor a minha banca de qualificação e por todas as orientações e inspirações.

Ao Prof. Dr. Marcelo Tadeu Motokane, por compor a minha banca de qualificação e por todas as anotações e sugestões de melhoria em meu trabalho.

Aos Prof. Dr. Antonio Carlos Marques, Prof. Dr. Carlos Arturo Navas Iannini, Prof. Dr. Paulo Takeo Sano e Profa. Dra. Vania Regina Pivello, responsáveis pela Disciplina 0410109 - Fauna, Flora e Ambiente, por autorizarem a aplicação do questionário e do teste nos ingressantes do CBio/USP/2006.

Aos Prof. Dr. Gregório Cardoso Tápias Ceccantini, Profa. Dra. Veronica Angyalossy e Profa. Dra. Gladys Flávia de Albuquerque Melo de Pinna, responsáveis pela Disciplina BIB0121 - Morfologia e Anatomia de Plantas Vasculares, por autorizarem a minha frequência nas aulas da referida disciplina como pesquisador em 2007.

Aos Prof. Dr. Jose Rubens Pirani e Prof. Dr. Renato de Mello Silva, responsáveis pela Disciplina BIB0123 - Taxonomia de Fanerógamas, por autorizarem a aplicação dos testes e dos questionários junto aos entrevistados da referida disciplina em 2007.

Aos entrevistados do Instituto de Biociências da USP, por toda a colaboração e boavontade em participar e contribuir com o levantamento de dados da minha pesquisa, em especial aos ingressantes do CBio/USP/2006, pois os acompanhei durante dois anos (20062007).

Finalmente, agradeço aos meus educandos, por me possibilitarem enxergar o discurso de Paulo Freire na prática, ao longo da minha vida profissional. 
"A educação ao longo de toda a vida baseia-se em quatro pilares: aprender a conhecer, aprender a fazer, aprender a viver juntos e aprender a ser."

(DELORS, 2003, p.101)

"O objetivo da educação nos parece ser a autonomia social do educando, e não a execução de uma cópia conforme um modelo. É assim que se pode dizer que o fim da educação é sem fim... Em vista da autonomia do educando, parecenos mais indicado favorecer uma descoberta pessoal e comunitária do mundo, que lhe faz tomar consciência do poder que pode usar, ao invés de lhe dar soluções já feitas o que o tornarão ao mesmo tempo dependente e centrado em si mesmo."

(FOUREZ, 2008, p. 40) 


\section{RESUMO}

PUCINELLI, Ricardo Henrique. Aprendizado dos conceitos de flor e fruto e sua utilização pelos alunos de Ciências Biológicas do I.B. - USP. 2010. 180 p. Dissertação (Mestrado em Ensino de Ciências - Ensino de Biologia) - Instituto de Física, Instituto de Química, Instituto de Biociências, Faculdade de Educação, Universidade de São Paulo, São Paulo, 2010.

O sujeito ingressante no ensino superior tende a passar por um processo de adaptação da sua linguagem (senso comum) para a linguagem científica, uso restrito dos centros acadêmicos e universitários, na maioria das vezes. Desta forma, o universitário passa a conviver com duas realidades - a do "mundo prático" e a do "mundo acadêmico" (MINOGUE, 1981). O universitário, então, encontra-se diante do desafio de adequar-se às novas regras e às práticas do ensino superior. A nossa pesquisa teve como objetivos verificar como estes "sujeitos da aprendizagem" (LEVINAS, 1998) conciliam a práxis universitária com a sua formação acadêmica, sem se desvencilhar dos objetivos das Ciências - entender a natureza. Outros dois objetivos também foram delimitados, ou seja, procuramos verificar: $1^{\circ}$ ) que significados os ingressantes do curso de Ciências Biológicas da USP dão aos conceitos - flor e fruto; $2^{\circ}$ ) se esses significados sofrem "adequações" ao longo de dois anos no Instituto de Ciências Biológicas da USP. Para tanto, utilizamos-nos dos instrumentos - questionário e teste de confrontação, em três momentos distintos, a saber: no primeiro dia de aula da disciplina Flora, Fauna e Ambiente, em 2006; no primeiro dia de aula na disciplina Morfologia e Anatomia de Plantas Vasculares, em meados de 2007; e no último dia de aula da disciplina Taxonomia de Fanerógamas, no final de 2007. As "falas" dos entrevistados foram categorizadas, com base na metodologia de Laurence Bardin (2008), onde o mesmo, comparando um "analista" a um "arqueólogo", afirma que o "analista" trabalha com "vestígios", ou seja, documentos que podem ser "naturais" ou "criados" e que permitem ao mesmo assumir uma "postura crítica" a partir do tratamento das mensagens que "manipula" para "inferir" conhecimentos sobre o "emissor da mensagem" ou sobre o "seu meio", por exemplo. Assim sendo, os dados nos demonstraram que os ingressantes apresentam diversos conflitos de conhecimento com os signos analisados (flor e fruto). Além disso, os mesmos buscam um referencial a ser seguido, pois ainda se encontram na fase de transição entre os dois mundos - o prático e o acadêmico. Após um ano do ingresso no curso de Ciências Biológicas, os alunos já apresentam uma estabilidade maior nas "suas falas", mas ainda podemos perceber que os conflitos de conhecimento permanecem. Ao final de dois anos de curso, os alunos apresentam um aumento considerável de vocabulário, o que favorece uma visão mais clara do significado dos objetos de conhecimento, mas, ao mesmo tempo, também ampliam as suas possibilidades de atribuírem significados divergentes das concepções do mundo acadêmico atribuídos aos signos. Em relação à formação profissional, os sujeitos analisados apresentam uma motivação pessoal voltada para a conclusão do curso dentro do prazo mínimo estabelecido pela Instituição de Ensino além de poderem exercer o bacharelado. Finalmente, constatamos que, no nosso caso, as práticas metodológicas voltadas para o ensino superior ainda se baseiam principalmente nas "falas" dos professores, ou seja, aulas expositivas e práticas de laboratório com o reforço das "falas" iniciais e as práticas avaliativas ainda são marcadas por dois tipos: a prova dissertativa e a prova prática.

Palavras-chaves: Botânica - Estudo e ensino; Botânica - Aprendizagem; Ensino Superior. 


\begin{abstract}
PUCINELLI, Ricardo Henrique. Learning concepts of flower and fruit and their use by students of biological sciences IB - USP. 2010. 180 p. Dissertation (Masters in Science Education - Biology Education) - Physics Institute, Chemistry Institute, Bioscience Institute, Education Faculty, University of São Paulo, São Paulo, 2010.
\end{abstract}

The newcomer student in higher education tends to go through a process of adapting their language (common sense) to scientific language, restricted use of the academic centers and universities, most of the time. Thus, the University begins to face two realities - the one related to "practical world" and the other associated to "academic" (MINOGUE, 1981). The academic student, then, is faced with the challenge of adapting to new rules and practices of higher education. Our research aims to explore how these "subjects of learning" (LEVINAS, 1998) reconcile the practice with their university academic, not to let go of the goals of science - to understand the nature. Two other goals were also defined, i.e., we checked: $1^{\circ}$ ) what were the concepts that beginners students of the Biological Sciences degree, USP, give to - flower and fruit, and $2^{\circ}$ ) whether these meanings are suffering "adjustments" over two years at the of Biological Sciences degree at USP. We used ourselves the following tools: questionnaire and test of confrontation, in three separate stages, namely: the first day of school discipline Flora, Fauna and Environment, in 2006, the first day of school discipline Morphology and Anatomy Vascular Plants in mid - 2007, and the last day of school discipline Taxonomy Phanerogam at the end of 2007. The "lines" of the respondents were categorized based on the methodology Laurence Bardin (2008), where the same, comparing an "analyst" to an "archaeologist", states that the "analyst" working with "traces", i. e. documents that can be "natural" or "created" and allow him to even take a "critical attitude" from the processing of messages that "handles" to "infer" knowledge of the "sender's message" or on "your way "for example. Therefore, the data showed us that the freshmen have several conflicts with knowledge of the signs examined (flower and fruit). Moreover, they find out a reference to be followed, as still in transition between the two worlds - the practical and academic. After a year of enrolling in the course of Biological Sciences, students already have a greater stability in their "speech, but we can see that the conflict of knowledge remain. At the end of two-year course, students present a considerable increase in vocabulary, which clarifies the view of the significance of the objects of knowledge, but at the same time, also expand their ability to attach different meanings of the conceptions of the world academic attributed to signs. Regarding training, the subjects discussed have a personal motivation toward completing the course within the time limit set by the education institution and they can pursue a bachelor's degree. Finally, we found out that, in our case, methodological practices aimed at higher education is still mainly based on "lines" of teachers, i.e., lecture and laboratory practice with the strengthening of "speech" and initial assessment practices have are marked by two types: the essay question exams and practical exam.

Keywords: Botany - Study and Education; Botany - Learning; Higher Education. 


\section{LISTA DE QUADROS}

Quadro 1 - Abordagem Tradicional

Quadro 2 - Abordagem Comportamentalista

Quadro 3 - Abordagem Humanista 


\section{LISTA DE FIGURAS}

Figura 1 - Representação didática ilustrando uma flor completa e suas partes constituintes.

Figura 2 - Esquema didático do ciclo vital das angiospermas

Figura 3 - Esquema didático de inflorescência 46

Figura 4 - Esquema didático de tipos de fruto 48

Figura 5 - Questão 93, extraída da Fuvest/2006, $1^{\text {a fase, Biologia. }} 69$

Figura 6 - Questão 5, extraída da Fuvest/2006, 2ª fase, Biologia. 70

Figura 7 - Respostas do entrevistado FFA/13/2006 em relação ao item T1q12. 88

Figura 8 - Respostas do entrevistado FFA/021/2006 ao item T1q15, sobre o que ele considera como sendo um fruto. 95

Figura 9 - Respostas do entrevistado FFA/032/2006 ao item T1q15, sobre o que ele considera como sendo um fruto. 96

Figura 10 - Respostas do entrevistado FFA/035/2006 ao item T1q15, sobre o que ele considera como sendo um fruto. 96

Figura 11 - Respostas do entrevistado FFA/044/2006 ao item T1q15, sobre o que ele considera como sendo um fruto. 97

Figura 12 - Respostas do entrevistado MAPV/009/2007 em relação ao item T2q8. 110

Figura 13 - . Respostas do entrevistado MAPV/033/2007 ao item T2q9, sobre o que ele considera como sendo um fruto. 116

Figura 14 - Respostas do entrevistado MAPV/001/2007 ao item T2q9, sobre o que ele considera como sendo um fruto. 116

Figura 15 - Respostas do entrevistado TF/005/2007 ao item T3q17, sobre o que ele considera como sendo uma flor.

Figura 16 - Respostas do entrevistado TF/030/2007 ao item T3q17, sobre o que ele considera como sendo uma flor. 152

Figura 17 - Respostas do entrevistado TF/036/2007 ao item T3q17, sobre o que ele considera como sendo uma flor.

Figura 18 - Respostas do entrevistado TF/005/2007 ao item T3q18, sobre o que ele considera como sendo um fruto. 157

Figura 19 - Respostas do entrevistado TF/030/2007 ao item T3q18, sobre o que ele considera como sendo um fruto. $\quad 158$

Figura 20 - Respostas do entrevistado TF/036/2007 ao item T3q18, sobre o que ele considera como sendo um fruto. 158 


\section{LISTA DE GRÁFICOS}

Gráfico 1 - Porcentagem dos Ingressantes do CBio/USP/2006 que frequentaram escola pública, particular e/ou ambas.

Gráfico 2 - Porcentagem dos Ingressantes do CBio/USP/2006 que frequentam um curso superior pela primeira vez, ou não.

Gráfico 3 - Porcentagem dos ingressantes do CBio/USP/2006 que fizeram uso de material didático ao longo do ensino médio.

Gráfico 4 - Relação dos materiais didáticos utilizados durante o ensino médio, por escola.

Gráfico 5 - Porcentagem dos ingressantes do CBio/USP/2006 que tiveram aulas de Botânica, durante o ensino médio.

Gráfico 7 - Porcentagem dos ingressantes do CBio/USP/2006 que fizeram "cursinho" antes de ingressar no CBio/USP/2006.

Gráfico 8 - Relação dos ingressantes do CBio/USP/2006 que afirmam reconhecer sempre ou às vezes, uma flor.

Gráfico 9 - Porcentagem dos ingressantes do CBio/USP/2006 que tiveram aulas sobre fruto, no ensino médio.

Gráfico 10 - Relação dos ingressantes do CBio/USP/2006 que afirmam reconhecer sempre ou às vezes, um fruto.

Gráfico 11 - Porcentagem dos ingressantes do CBio/USP/2006 que estavam cursando pela primeira vez o segundo ano, no curso de Ciências Biológicas da USP.

Gráfico 12 - Porcentagem dos entrevistados que afirmam que tiveram os conceitos de 'flor' e de 'fruto' abordados em disciplinas anteriores

Gráfico 13 - Porcentagem dos entrevistados que fizeram estágio, com enfoque em plantas superiores.

Gráfico 14 - Porcentagem dos entrevistados que afirmam reconhecer sempre ou às vezes, uma flor.

Gráfico 15 - Porcentagem dos entrevistados que afirmam reconhecer sempre, às vezes ou não, um fruto.

Gráfico 16 - Porcentagem dos entrevistados da Disciplina TF/0123 que estão fazendo pela primeira vez a disciplina.

Gráfico 17 - Porcentagem dos entrevistados que afirmam que os conceitos de flor e de fruto foram abordados em disciplinas anteriores à disciplina TF/0123.

Gráfico 18 - Porcentagem dos entrevistados que percebem alguma correlação da Disciplina TF/0123 com disciplinas anteriores.

Gráfico 19 - Relação do $n^{\circ}$ de alunos por crédito feito no $2^{\circ}$ semestre/2007.

Gráfico 20 - Porcentagem dos entrevistados de TC/0123 que fazem leituras extras além do material fornecido durante o curso.

Gráfico 21 - Frequência dos entrevistados que fazem uso da Internet para complemento dos estudos.

Gráfico 22 - Frequência do uso da biblioteca para estudos.

Gráfico 23 - Porcentagem dos entrevistados que fizeram estágio, com enfoque em plantas superiores.

Gráfico 24 - Porcentagem de diversos recursos didáticos usados ou não em aula.

Gráfico 25 - Porcentagem das ‘técnicas de avaliação' usadas ou não usadas em aula.

Gráfico 26 - Porcentagem dos entrevistados que afirmam reconhecer sempre, às vezes ou não, uma flor.

Gráfico 27 - Porcentagem dos entrevistados que afirmam reconhecer sempre, às vezes ou não, um fruto. 


\section{LISTA DE TABELAS}

Tabela 1 - Itens e eixos investigativos relacionados ao primeiro questionário (Q1)

Tabela 2 - Itens e eixos investigativos relacionados ao segundo questionário (Q2)

Tabela 3 - Itens e eixos investigativos relacionados ao terceiro questionário (Q3)

Tabela 4 - Categorização do conceito de flor do ingressantes do CBio/USP/2006

Tabela 5 - Respostas dos Ingressantes do CBio/USP/2006, obtidas em relação ao item T1q14, quando solicitados a circundar o que eles consideram como sendo "uma flor" 86

Tabela 6 - Categorização do conceito de fruto do ingressantes do CBio/USP/2006

Tabela 7 - Respostas dos Ingresantes do CBio/USP/2006, obitdas em relação ao item T1q15, quando solicitados a circundar o que consideram como sendo "um fruto"

Tabela 8 - Disciplinas que abordaram os conceitos de 'flor'e de ‘fruto' em 2006 apontadas pelos entrevistados da disciplina MAPV/0121

Tabela 9 - Categorização do conceito de flor pelos entrevistados da disciplina MAPV/0121

Tabela 10 - Respostas dos entrevistados da disciplina MAPV/0121, obtidas em relação ao item T2q8 quando solicitados a circundar o que eles consideram como sendo "uma flor"

Tabela 11 - Categorização do conceito de fruto pelos entrevistados da disciplina MAPV/0121

Tabela 12 - Respostas dos entrevistados da disciplina MAPV/0121, obtidas em relação ao item T2q9, quando solicitados a circundar o que eles consideram como sendo "um fruto"

Tabela 13 - Disciplinas que abordaram os conceitos de 'flor'e de 'fruto' em 2006/2007 apontadas pelos entrevistados da disciplina TF/0123

Tabela 14 - Disciplinas que abordaram os conceitos de 'flor'e de 'fruto' 'sempre' e 'às vezes' em 2006/2007 apontadas pelos entrevistados da disciplina TF/0123

Tabela 15 - Motivações apontadas pelos entrevistados de TF/0123 para frequentar as aulas

Tabela 16 - Categorização do uso da Internet pelos entrevistados da disciplina TF/0123 - opção 'Sim, sempre'.

Tabela 17 - Categorização do uso da Internet pelos entrevistados da disciplina TF/0123 - opção 'Às vezes'

Tabela 18 - Categorização do uso da biblioteca pelos entrevistados da disciplina TF/0123 opção 'Sim, sempre'

Tabela 19 - Categorização do uso da biblioteca pelos entrevistados da disciplina TF/0123- opção 'Às vezes'

Tabela 20 - Categorização das causas pelas quais os entrevistados da TF/0123 estudam

Tabela 21 - Categorização do conceito de flor pelos entrevistados da disciplina TF/0123

Tabela 22 - Respostas dos entrevistados da disciplina TF/0123, obtidas em relação ao item T3q17, quando solicitados a circundar o que eles consideram como sendo "uma flor"

Tabela 23 - Categorização do conceito de fruto pelos entrevistados da disciplina TF/0123

Tabela 24 - Respostas dos entrevistados da disciplina TF/0123, obtidas em relação ao item T3q8, quando solicitados a circundar o que consideram como sendo "um fruto" 


\section{SUMÁRIO}

$\begin{array}{lc}\text { Lista de quadros } & \text { XII }\end{array}$

\begin{tabular}{lc} 
Lista de figuras & XIII \\
\hline
\end{tabular}

\begin{tabular}{ll} 
Lista de gráficos & XIV \\
\hline
\end{tabular}

$\begin{array}{ll}\text { Lista de tabelas } & \text { XV }\end{array}$

$\begin{array}{lr}\text { Introdução } & 15\end{array}$

1. Capítulo: conhecimento e instrução: princípios da aprendizagem 24

1.1. As abordagens de ensino $r$

1.2. Aprendizagem no ensino superior: uma realidade possível 34

2. Capítulo: Os conceitos de flor e de fruto no ensino superior 40

2.1. O conceito de flor no ensino superior $\quad 41$

2.2. O conceito de fruto no ensino superior $\quad 47$

2.3. Considerações finais $\quad 49$

3. Capítulo: materiais e métodos $\quad 50$

$\begin{array}{lr}\text { 3.1. Os questionários e os testes } & 50\end{array}$

3.2. A aplicação dos questionários e dos testes e suas análises $\quad 55$

$\begin{array}{ll}\text { 3.2.1. A análise dos dados } & 61\end{array}$

4. Capítulo: resultados e discussão $\quad 68$

$\begin{array}{ll}\text { 4.1. Ingressantes do curso de Ciências Biológicas da USP - } 2006 & 68\end{array}$

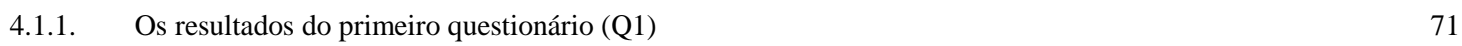

4.1.1.1. Os conceitos morfológicos de flor e de fruto presentes no discurso dos ingressantes do $\mathrm{CBio} / \mathrm{USP} / 2006$

4.2. Ingressantes do curso de Ciências Biológicas da USP - 2006 após um ano

4.2.1. Os conceitos de flor e de fruto presentes no discurso dos ingressantes do curso de Ciências

Biológicas da USP - 2006 após um ano na USP

4.3. Ingressantes do curso de Ciências Biológicas da USP - 2006 após dois anos - entrevistados da disciplina Taxonomia de Fanerógamas (TF/0123)

4.3.1. As relações dos entrevistados de TF/0123 com a sua formação profissional

4.3.2. As relações dos sujeitos da aprendizagem com as metodologias de ensino empregadas na sua formação

4.3.3. Os conceitos de flor e de fruto pelos entrevistados da disciplina Taxonomia de Fanerógamas

$$
\text { (TF/0123) }
$$

5. Capítulo: considerações finais $\quad 161$

6. Bibliografia 163

Anexo A - Questionário aplicado aos entrevistados da disciplina Fauna, Flora e Ambiente 172

Anexo B - Teste aplicado aos entrevistados da disciplina Fauna, Flora e ambiente 174

Anexo C - Questionário aplicado aos entrevistados da disciplina Morfologia e Anatomia de Plantas Vasculares 175

Anexo D - Teste aplicado aos entrevistados da disciplina Morfologia e Anatomia de Plantas Vasculares 177

Anexo E - Questionário aplicado aos entrevistados da disciplina Taxonomia de Fanerógamas 178

Anexo F - Teste aplicado aos entrevistados da disciplina Taxonomia de Fanerógamas 181

Anexo G - Programa da disciplina Anatomia e Morfologia de Plantas Vasculares 182

Anexo H - Cronograma da disciplina Anatomia e Morfologia de Plantas Vasculares 187

Anexo I - Prova Objetiva de Biologia da Fuvest/2006 188

Anexo J - Prova Dissertativa de Biologia da Fuvest/2006 189 


\section{INTRODUÇÃO}

O senhor... mire veja: o mais importante e bonito, do mundo é isto: que as pessoas não estão sempre iguais, ainda não foram terminadas - mas que elas vão sempre mudando. Verdade maior. É o que a vida me ensinou. Isso que me alegra, montão.

João Guimarães Rosa - Grande Sertão Veredas.

A verdade sobre a nossa história educacional ainda está sendo escrita nas vidas dos profissionais que concluem o ensino superior e ingressam no mercado de trabalho em busca de novos desafios, dentre eles, o de colocarem em prática o conhecimento que adquiriram ao longo da sua formação acadêmica. E esse conhecimento acadêmico, fruto do esforço coletivo de pesquisadores se condensa ao longo dos séculos.

Por sua vez, esses conhecimentos acadêmicos gradativamente transpõem a barreira do universo acadêmico através do esforço coletivo da sociedade e da "pressão" imposta pelos órgãos governamentais à própria universidade, refletindo na reorganização da sociedade de forma significativa e, ao mesmo, criando condições e novos desafios para as Universidades de todo o mundo, permitindo que os dois polos de convergência ("mundo prático" e "mundo acadêmico") se mantenham em equilíbrio (MINOGUE, 1981).

Sacristán (2007, p. 64) defende a ideia de que a educação que se exige hoje pela sociedade é uma "escolaridade mais substancial", no sentido de maior "relevância" para o educando, despertando na sociedade a "necessidade de se seguir aprendendo".

Neste sentido, atualmente a Biologia é um campo florescente de investigação. Para Mayr (2008, p. 9): 
Testemunhamos revoluções sem precedentes na genética, na biologia celular e na neurociência, bem como avanços espetaculares na biologia evolutiva, na antropologia física e na ecologia. Toda uma indústria surgiu a partir da pesquisa em biologia molecular; seus resultados são claramente visíveis em campos tão distintos quanto a medicina, a agricultura, a reprodução animal e a nutrição humana, para citar só alguns. (MAYR, 2008, p. 9)

Consequentemente, a Biologia tem despertado o interesse de muito jovens para ingressarem neste mundo complexo que é a ciência. Em especial na Universidade de São Paulo (USP), para onde focamos as nossas atenções neste estudo. Ao analisar os dados estatísticos sobre o curso de Ciências Biológicas em São Paulo-SP, disponíveis na Internet ${ }^{1}$, pudemos constatar um aumento significativo entre os anos 2000 a 2005, sendo que, em 2005, tornou-se o $6^{\circ}$ curso mais concorrido da Fuvest ${ }^{2}$, com 3437 inscritos como primeira opção de curso. Neste período, com os estudos do Projeto Genoma e outras publicações surgindo na área da Biologia, muitos vislumbraram nas "ciências da vida" uma possibilidade de também fazerem ciência.

Segundo a Lei $\mathrm{n}^{\circ}$ 6684/79, de 03 de setembro de 1979 que regulamentou a profissão de Biólogo e criou os Conselhos Federais e Regionais de Biologia, modificada pela Lei $n^{\circ}$ 7017/82, de 03 de agosto de 1983, o Biólogo é definido como o portador do diploma:

Art. $1^{0}[\ldots]$ :

I - devidamente registrado, de bacharel ou licenciado em curso de História Natural, ou de Ciências Biológicas, em todas as suas especialidades ou de licenciado em Ciências, com habilitação em Biologia, expedido por instituição brasileira oficialmente reconhecida;

Il - expedido por instituições estrangeiras de ensino superior, regularizado na forma da lei, cujos cursos forem considerados equivalentes aos mencionados no inciso I.

Art. $2^{\circ}$ Sem prejuízo do exercício das mesmas atividades por outros profissionais igualmente habilitados na forma da legislação específica, o Biólogo poderá:

\footnotetext{
${ }^{1}$ FUVEST. In: < http://www.fuvest.br/vest2009/estat/estat.stm>. Acessado em: 29 dez. 2009.

2 Em 29 de abril de 2005, o jornal A Folha de S. Paulo, publicou um Caderno Especial, falando sobre colégios. Neste encarte, a Repórter Laura Capriglione aponta o curso de Ciências Biológicas de São Paulo, como o 6응 colocado na lista de cursos mais concorridos no Vestibular da Fuvest, ficando atrás apenas dos seguintes

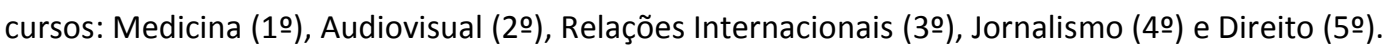


I - formular e elaborar estudo, projeto ou pesquisa científica básica e aplicada, nos vários setores da Biologia ou a ela ligados, bem como os que se relacionem à preservação, saneamento e melhoramento do meio ambiente, executando direta ou indiretamente as atividades resultantes desses trabalhos;

II - orientar, dirigir, assessorar e prestar consultoria a empresas, fundações, sociedades e associações de classe, entidades autárquicas, privadas ou do poder público, no âmbito de sua especialidade;

III - realizar perícias e emitir e assinar laudos técnicos e pareceres de acordo com o currículo efetivamente realizado.

Tendo esses apontamentos em mente, tornar-se um Biólogo, atualmente, exige do profissional um empenho muito grande em querer se atualizar sempre, pois como lamenta Mayr (2008, p. 10), muitos dos biólogos atualmente tendem a ter uma visão obsoleta das "ciências da vida", pelo fato de se tornarem cada vez mais "especialistas" em suas áreas de pesquisa e se "desinformarem no que diz respeito àquilo que acontece fora do seu campo de especialização”.

Por sua vez, a sociedade em si, intitulada por Minogue (1981) de "mundo prático", traz como cultura a necessidade de que o conhecimento produzido pelo "mundo acadêmico" (universidade, senso amplo) seja de utilidade pública para uso imediato, por meio de uma “pressão governamental".

Além disso, em um editorial publicado em 23 jan. 2009, o pesquisador Bruce Alberts, da Harvard e editor da revista "Science", desafia a comunidade científica para um novo ciclo de inovação no ensino de ciências e aponta as seguintes metas: preparar os estudantes para gerar e avaliar evidências científicas e suas explicações, entender a natureza e o desenvolvimento do conhecimento científico e participar de forma produtiva das práticas científicas.

Para Minogue (1981, p. 61),

A praxe das universidades é apresentada como uma 'Sala' ou 'mundo' próprio, logicamente, um tanto distinto institucionalmente, de outros tipos de conceito. A pesquisa acadêmica é um tipo de busca do conhecimento de qualquer coisa de modo geral, um método caracterizado sem dúvida pelos seus objetivos e preocupações, 
embora diferenciado acima de tudo por uma lógica totalmente diversa daquela da prática. (MINOGUE, 1981, p. 61)

Isso nos remete a pensar que a cultura gerada dentro da Universidade (senso amplo), provoca o surgimento de uma espécie de "significado encontrado nos discursos acadêmicos" diferente do "discurso encontrado no mundo" (MINOUGUE, 1981; LEVINAS, 1998; LATOUR, 2000). Ou seja, o sujeito ingressante na Universidade tende a passar por um processo de adaptação à linguagem científica, adaptação essa já provocada pela sua formação anterior por intermédio dos estudos oferecidos no ensino fundamental e no ensino médio (LEVINAS, 1998).

Minogue (ibid., p. 62) aponta que esse "mundo próprio" da Universidade passa a se ligar e, ao mesmo, distanciar-se do "mundo prático" por meio de alguns elementos comuns a ambos. Como exemplo, ele cita as diferentes visões sobre a "aplicação" do conhecimento acadêmico no seu próprio mundo bem como no mundo prático. Para o autor, segundo a concepção do "monismo", caberia ao mundo acadêmico "produzir conhecimentos estéreis até serem vinculados a um objetivo, gerando uma consequência prática". Outro mecanismo comumente usado para distinguir o mundo acadêmico do mundo prático seria "a distinção entre meios e fins". Para o autor "as Universidades se ocupam primordialmente com a teoria pura [meio], enquanto que a aplicação depende das necessidades geradas pelos desejos humanos [fins]". E, finalmente, o terceiro mecanismo para separar os dois mundos é justamente "a distinção entre o fato e o juízo de valor". Neste sentido, o autor exemplifica comentando que "um engenheiro academicamente treinado não está mais qualificado do que o homem comum para decidir que pontes deveriam ser levantadas e onde estas seriam construídas". Neste sentido, o autor enfatiza que a finalidade primordial para a busca do conhecimento segundo o "monismo" está restrita apenas ao seu “controle". 
Outro fator que pode gerar uma distinção destes dois mundos é justamente a questão da relevância. Segundo Minogue (1981, p. 66), "para o mundo acadêmico, o único critério relevante é o da verdade ou da falsidade; [...], na prática, o critério [...] é a da eficácia”. Faz-se essa distinção justamente por conta da crença que cada um possui em relação à maneira como lidam com conhecimento.

Concluindo essa distinção entre os dois mundos, Minogue (ibid., p. 77) diz que

O distanciamento entre interesses práticos e objetivos acadêmicos deve ser visto não como uma tradição sobrevivente de épocas menos esclarecidas, mas como uma condição essencial de subsistência do mundo acadêmico. O mundo prático é aquele no qual não podemos deixar de viver, mas o mundo acadêmico requer educação especial, e não veio a existir de modo significativo, até muito recentemente. E a condição de sua sobrevivência seria que ele fosse isolado da tarefa essencialmente prática da tomada de decisões. No mundo de responsabilidades práticas, têm de se tomar decisões, [mesmo se arriscando para ver o que acontece]; [...] a preocupação essencial do mundo acadêmico é só com a irrefutabilidade da prova: o que a prova vai propor e ao que a prova vai resistir. Os acadêmicos [...] [consideram apenas] até que ponto estão habilitados, [...], a chegarem a uma conclusão. (MINOGUE, 1981, p. 61)

No Brasil isso não é diferente, haja vista que, na Constituição de $1988^{3}$, vê-se uma cobrança para que o ensino superior vincule a sua pesquisa acadêmica às necessidades da sociedade. Além dessa cobrança constante e cada vez maior da aplicação do conhecimento científico nas questões práticas da sociedade, Pimenta e Anastasiou (2002, p. 97) pontuam outros desafios a serem enfrentados pelas Universidades, dentre eles, o mais genérico, seria justamente o de

[...] [através da educação] garantir que [as crianças e os jovens] se apropriem do instrumental científico, técnico, tecnológico, de pensamento, político, social e econômico, de desenvolvimento cultural, para que sejam capazes de pensar e gestar soluções. Apropriar-se dessa riqueza da civilização e dos problemas que essa mesma civilização produziu [imensos problemas de desigualdade social, econômica e cultural]. [...] Dela [educação] se solicita que forme seres humanos capazes de criar e oferecer respostas aos desafios que diferentes contextos políticos e sociais

\footnotetext{
${ }^{3}$ Cf. artigos 214 e 218 da op. cit.
} 
produzem. A educação, enquanto reflexo, retrata e reproduz a sociedade; mas também projeta a sociedade que se quer. (PIMENTA \& ANASTASIOU, 2002, p. 97)

A praxe universitária está atrelada ao processo de formação de novos pesquisadores, profissionais das mais diversas áreas de conhecimento, por excelência, em condições de produzir conhecimento fora e dentro do mundo acadêmico. Ou seja, a formação de um novo cientista está ligada aos processos de ensino-aprendizagem que se exercem na Universidade.

Tradicionalmente, o ensino superior está muito centrado no professor - pesquisador e orientador -, fazendo com que o aluno torne-se agente passivo do seu próprio processo de aquisição do conhecimento.

O aluno também tem o seu papel no processo de ensino e na construção do seu saber, desenvolvendo pesquisa e levantando hipóteses, mas de uma forma muito elementar e subjetiva em relação ao conteúdo curricular, geralmente em atividades extraclasse e/ou transcrevendo nas provas o conhecimento que lhe foi "transferido" ao longo das aulas.

Doxsey (1986, p. 149) reforça a ideia de que a formação profissional no ensino superior tem se limitado, na maioria das universidades do país, à aquisição de conhecimentos e teorias, ou seja, à formação de uma base científica e técnica de "informação" e "fatos".

Ainda sobre o assunto, Doxsey (1986, p. 149) afirma que:

\footnotetext{
"Este processo está destinado a ser incompleto e limitado, além de frustrante, tanto para o aluno como para o professor. É frustrante porque o aluno percebe logo a falta de integração dos conteúdos transmitidos, sua irrelevância para a profissão que pretende exercer, e a distância que separa a "teoria da prática". Além disso, ao chegar na Universidade, o aluno observa que as disciplinas básicas são fragmentadas, e que cada professor justifica a importância do conteúdo dos seus programas de ensino como fundamento para outros conhecimentos." (DOXSEY, 1986, p. 149)
} 
Segundo os modelos didáticos propostos nas últimas décadas, a ênfase atual no processo de ensino-aprendizagem acentua a importância de o aluno trabalhar as informações para transformá-las em saber; contrapondo-se ao ensino tradicional em que os professores apresentam as definições, explicam os fenômenos, demonstram teoremas, estabelecem as relações de causa e efeito, justificam pontos de vista e determinam as conclusões sobre o assunto tratado.

Micotti (1997, p. 9) trazendo para a discussão essa ideia de inovação pedagógica nas propostas de ensino, esclarece-nos que a aprendizagem

[...]deixa de ser considerada como um processo mecânico, no qual uma série de informações é recebida de forma passiva para serem gravadas na mente e, depois, desenvolvidas na avaliação do mesmo modo que foram recebidas. A aprendizagem por interação do aluno com o objeto de estudo constitui processo dinâmico em que ele, com base nos conhecimentos que já tem sobre o assunto, faz sua própria interpretação selecionando os aspectos que mais chamam a sua atenção, apreendendo as relações entre esses vários aspectos, atribuindo significados às suas observações, etc...” (MICOTTI, 1997, p. 9)

Como ressalta Pimenta e Anastasiou (2002, p. 164), pensando sobre o ensino universitário como um "processo de busca, de construção científica e de crítica ao conhecimento produzido", ou seja, "ao seu papel na construção da sociedade", destacam algumas atribuições que o marcam e que, a nosso ver, também se instituem como desafios atuais, que são:

a) propiciar o domínio de um conjunto de conhecimentos, métodos e técnicas científicos, que assegurem o domínio científico e profissional do campo específico e devem ser ensinados criticamente (isto é, em seus nexos com a produção social e histórica da sociedade). Para isso, o desenvolvimento de habilidades de pesquisa é fundamental;

b) conduzir a uma progressiva autonomia do aluno na busca de conhecimentos;

c) considerar o processo de ensinar/aprender como atividade integrada à investigação;

d) desenvolver a capacidade de reflexão; 
e) substituir a simples transmissão de conteúdos por um processo de investigação do conhecimento;

f) integrar, vertical e horizontalmente, a atividade de investigação à atividade de ensinar do professor, o que supõe trabalho em equipe;

g) criar e recriar situações de aprendizagem;

h) valorizar a avaliação diagnóstica e compreensiva da atividade mais do que a avaliação como controle;

i) conhecer o universo cultural e de conhecimentos dos alunos e desenvolver, com base nele, processos de ensino e aprendizagem interativos e participativos.

(PIMENTA \& ANASTASIOU, 2002, p. 164)

Dentro da formação científica do biólogo, Raw et. al. (2001) apontam que hoje temos um grande desafio, "o de abandonarmos a ideia de que essa ciência constitui-se apenas em um conjunto de informações que precisam ser memorizadas" e, automaticamente, temos que substituí-la por "uma visão abrangente dos processos e resultados de investigação cujos avanços, em ritmo cada vez mais acelerado, ampliam o conhecimento de temas essenciais para a compreensão do impacto que produzem na vida moderna".

Diante de tantos desafios, de que forma o universitário tem lidado com o conhecimento para a sua formação acadêmica? Como conciliar aprendizado e formação profissional sem se distanciar do objetivo maior da ciência que, segundo Mayr (2008, p. 49) é “fazer avançar a nossa compreensão da natureza, por meio da resolução de problemas científicos"? Essa é uma questão complexa cuja resposta pretendemos colaborar em nossa pesquisa.

O segundo foco de estudo da nossa pesquisa, o aprendizado de conceitos biológicos no ensino superior, teve como objetivos principais, verificar:

1") que "concepções" os estudantes do Curso de Ciências Biológicas do Instituto de Biociências da Universidade de São Paulo (Ingressantes do CBio/USP/2006) trouxeram consigo da sua formação antes do ingresso no ensino superior, em especial, os conceitos de flor e de fruto; 
$2^{\circ}$ ) se esses "significados", ou de maneira distinta, se os conceitos biológicos apontados acima sofreram "adequações" ao longo da vivência acadêmica dos "sujeitos da aprendizagem", em especial durante o SEGUNDO ANO do curso de graduação, período este em que os Ingressantes do CBio/USP/2006 tiveram contato com as principais disciplinas de Botânica onde são elaborados e esmiuçados os conceitos de flor e fruto, ou seja, nas disciplinas: Morfologia e Anatomia de Plantas Vasculares/BIB - 0121 (MAPV/0121) e Taxonomia de Fanerógamas/BIB - 0123 (TF/0123).

$3^{\circ}$ ) que modalidades didáticas e quais os instrumentos de avaliação mais utilizados ao longo do processo de ensino-aprendizagem nas disciplinas: MAPV/0121 e TF/0123.

Para atingirmos os nossos objetivos, no capítulo 1 - Conhecimento e instrução: princípios da aprendizagem -, fizemos uma apresentação breve das abordagens de ensino categorizadas por Mizukami (1996) e discutimos o conceito de aprendizagem.

No capítulo 2 - Os conceitos de flor e de fruto no ensino superior de Biologia -, apresentamos os conceitos de flor e de fruto presentes na literatura voltada para o ensino superior.

No capítulo 3 - Materiais e métodos -, apresentamos a estrutura da pesquisa e também discutimos as ferramentas de análise de conteúdo apresentada por Laurence Bardin (2008).

No capítulo 4 - Resultados e discussão -, caracterizamos a nossa amostra e também fazemos uma análise dos resultados dos questionários e dos testes de confrontação aplicados ao longo dos dois anos em que acompanhamos os Ingressantes do CBio/USP/2006 na sua formação profissional.

No capítulo 5- Considerações finais, buscamos retomar a nossa discussão inicial, ponderando sobre o que nos foi possível observar ao longo da nossa pesquisa. 


\section{Capítulo 1. Conhecimento e Instrução: princípios da aprendizagem}

[...] olhar é, ao mesmo tempo, sair de si e trazer o mundo para dentro de si. Porque estamos certos de que a visão depende de nós e se origina em nossos olhos, expondo nosso interior ao exterior, falamos em janelas da alma. [...] ver é olhar para tomar conhecimento e para ter conhecimento. (CHAUÍ, 1997, p. 33-35)

A psicologia do ensino não dispõe, até este momento, de uma teoria única e aceita globalmente que ofereça um marco explicativo completo e detalhado dos processos de aprendizagem escolar. Porém, ao contrário, na dimensão teórico-conceitual da disciplina, coexistem diversas teorias e enfoques sobre a aprendizagem escolar que respondem a coordenadas históricas e epistemológicas diversas que proporcionam conceitos e princípios explicativos também diversos, podendo, às vezes, ser considerados complementares e, às vezes, dificilmente podem ser reconciliáveis ou de difícil reconciliação. A partir desta situação, este capítulo apresenta algumas das abordagens de ensino focadas nos seus elementos constituintes, ou seja, no homem, no mundo, na aprendizagem, no conhecimento, na sociedade, na cultura e nos processos que interligam esses elementos e se complementam.

O aprendizado, neste sentido, passa a ter um caráter indissociável de seu contexto sociocultural e histórico. Ao estudarmos as teorias voltadas para a compreensão dos processos que possibilitam a aprendizagem ou o aprendizado, podemos perceber que as mesmas surgiram a partir de demandas sociais, de estudos científicos, dos avanços da tecnologia, entre outros fatores. 


\subsection{As abordagens de ensino}

As abordagens de ensino a que nos reportaremos a partir deste momento, estão presentes em outro estudo, intitulado Ensino: as abordagens de um processo (MIZUKAMI, 1996).

Segundo a autora (ibid., p. 2 e ss.) as teorias de conhecimento em que são baseadas as escolas psicológicas e de onde provêm as tomadas de posições, podem ser consideradas, apesar das muitas variações e combinações possíveis, de acordo com três características: primado do sujeito, primado do objeto e na interação sujeito-objeto.

As concepções empiristas, pautadas no 'primado do objeto' consideram o organismo sujeito às condições do meio, sendo o conhecimento uma cópia de algo dado no mundo externo, ou seja, o sujeito é tido como uma "tabula rasa" e o conhecimento é uma “descoberta" e algo novo ao indivíduo que a faz.

Por sua vez, as concepções nativistas ou inatistas, estão pautadas no 'primado do sujeito', nas quais as formas de conhecimento estão determinadas no sujeito. Atribuem-se ao sujeito, ao organismo humano, categorias de conhecimento "já prontas", para as quais toda estimulação sensorial é canalizada.

Finalmente, as concepções interacionistas, pautadas na 'interação sujeito-objeto', vê o conhecimento como uma construção contínua, através da qual busca enfatizar uma relação dinâmica entre a bagagem genética hereditária e sua adaptação ao meio em que se desenvolve.

Assim sendo, para Misukami, toda interpretação do fenômeno vital, quer seja biológica, sociológica, psicológica, resulta de uma relação sujeito-ambiente, isto é, deriva de uma tomada de posição epistemológica em relação ao sujeito e ao meio. Subjacentes ao conceito de homem, de mundo, de aprendizagem, conhecimento, sociedade, cultura, estão presentes - implícita ou explicitamente - algumas dessas posições. Essas diferentes posições, 
por sua vez, podem implicar, do ponto de vista lógico, em diferentes aplicações pedagógicas. A seguir, apresentaremos cada uma dessas abordagens do ensino.

A autora considera que o ensino se caracteriza em cinco abordagens, a saber: a Tradicional, a Comportamentalista, a Humanista, a Cognitivista e a Sociocultural. Como o nosso objetivo é o de verificarmos o conceito de aprendizagem/aprendizado apresentado em cada uma dessas concepções de ensino, elaboramos os quadros sinópticos a seguir, pois nos permitirá ter uma visão destes conceitos sem perdermos a visão do todo da obra. Esses quadros não esgotam a obra consultada, mas nos permite ter uma visão generalizada e ampla das cinco abordagens citadas acima e das relações que se estabelecem entre os "sujeitos da aprendizagem" e o conhecimento.

No quadro 1, podemos visualizar as principais características da abordagem Tradicional. Também é concebida como a base para o desenvolvimento das outras abordagens, perpetuando-se até os dias atuais.

Quadro 1 - Abordagem Tradicional

\begin{tabular}{|c|c|}
\hline Categorias & Características \\
\hline Características gerais & $\begin{array}{l}\text { Ensino em que se privilegiam o especialista, os modelos e o professor - elemento } \\
\text { imprescindível na transmissão de conteúdos. }\end{array}$ \\
\hline Homem & $\begin{array}{l}\text { Receptor passivo até que, repleto de informações, as possam transmitir para outras } \\
\text { pessoas de modo eficiente em sua profissão. }\end{array}$ \\
\hline Mundo & Realidade externa ao indivíduo que o mesmo toma consciência gradativamente. \\
\hline Sociedade-cultura & $\begin{array}{l}\text { Sociedade baseada na "educação bancária", ou seja, uma educação caracterizada por } \\
\text { "depositar" no aluno, conhecimentos, modelos, dados, fatos, etc. } \\
\text { Diploma é visto como instrumento de hierarquização dos indivíduos na sociedade. }\end{array}$ \\
\hline Conhecimento & $\begin{array}{l}\text { Caráter "acumulativo", partindo-se de incorporações mais simples até as mais } \\
\text { complexas. }\end{array}$ \\
\hline Educação & $\begin{array}{l}\text { Instrução caracterizada como transmissão de conhecimentos fornecida } \\
\text { exclusivamente pela escola. }\end{array}$ \\
\hline Escola & Local por excelência onde se realiza a educação. \\
\hline
\end{tabular}

\section{Continua}




\section{Conclusão}

Quadro 1 - Abordagem Tradicional

\begin{tabular}{|c|l|}
\hline Categorias & \multicolumn{1}{|c|}{ Características } \\
\hline \multirow{2}{*}{ Ensino-aprendizagem } & $\begin{array}{l}\text { Ocorre em sala de aula, caracterizado por se preocupar mais com a variedade e } \\
\text { quantidade do que com a formação do pensamento reflexivo. A aprendizagem é } \\
\text { expressa pela (re)produção de conteúdos feitas o mais fiel possível à fala do } \\
\text { professor. }\end{array}$ \\
\hline Professor-aluno & Relação verticalizada: professor $\rightarrow$ aluno. \\
\hline Metodologia & $\begin{array}{l}\text { aulas expositivas com demonstrações do professor à classe, tomada quase como } \\
\text { auditório. } \\
\text { Professor = agente. } \\
\text { Aluno = ouvinte. }\end{array}$ \\
\hline Avaliação & $\begin{array}{l}\text { Visa à exatidão da reprodução do conteúdo comunicado em sala de aula. Mede-se, } \\
\text { portanto, pela quantidade e exatidão de informações que se consegue reproduzir. }\end{array}$ \\
\hline Considerações finais & $\begin{array}{l}\text { Apresenta programas minuciosos, rígidos e coercitivos. Baseia-se na transmissão de } \\
\text { conhecimentos de uma geração a outra, findada em si mesma. }\end{array}$ \\
\hline
\end{tabular}

Fonte: Mizukami (1996)

No quadro 2, apresentamos a abordagem Comportamentalista que se baseia, principalmente, nos estudos de Skinner. A partir desta abordagem, surge o termo americano behavior - que significa 'comportamento'; por isso, essa abordagem também é denominada de abordagem Behaviorista. Aqueles que se interessarem em aprofundar os estudos desta abordagem poderão vislumbrá-las melhor, segundo Salvador et al. (2000), nas obras de Swenson (1984), Hill (1980) ou Hilgard e Bower (1980).

Quadro 2 - Abordagem Comportamentalista

\begin{tabular}{|c|l|}
\hline \multicolumn{1}{|c|}{ Categorias } & \multicolumn{1}{c|}{ Características } \\
\hline Características gerais & $\begin{array}{l}\text { Toma como base os estudos de comportamentalistas como, por exemplo, Skinner. O } \\
\text { conhecimento é visto como o resultado direto da experiência. }\end{array}$ \\
\hline Homem & Consequência das influências ou forças existentes no meio ambiente. \\
\hline Mundo & O mundo já é construído e o homem é o produto do meio. \\
\hline Sociedade-cultura & \begin{tabular}{l} 
A cultura é entendida como um conjunto de contingências de reforço. O papel do \\
homem na sociedade se restringe a exercer as funções que se espera sejam realizadas \\
de maneira eficiente. \\
\hline Conhecimento
\end{tabular} \\
\hline É estruturado indutivamente, via experiência. \\
\hline
\end{tabular}


Conclusão

Quadro 2 - Abordagem Comportamentalista

\begin{tabular}{|c|c|}
\hline Categorias & Características \\
\hline Educação & $\begin{array}{l}\text { Está voltada para a transmissão de conhecimentos e habilidades consideradas básicas } \\
\text { para a manipulação e controle do mundo / ambiente (cultural, social, etc.). }\end{array}$ \\
\hline Escola & Promove a conservação dos modelos sociais desejáveis. \\
\hline Ensino-aprendizagem & $\begin{array}{l}\text { Consiste em um arranjo e planejamento de contingências sob as quais os alunos } \\
\text { aprendem e é de responsabilidade do professor assegurar a aquisição do } \\
\text { comportamento. Aprendizagem baseada na programação estímulo } \rightarrow \text { resposta. }\end{array}$ \\
\hline Professor-aluno & $\begin{array}{l}\text { Aos professores cabe planejar e executar contingências de reforços em relação às } \\
\text { respostas desejadas dos alunos. }\end{array}$ \\
\hline Metodologia & $\begin{array}{l}\text { Ensino individualizado, focado nas respostas dos alunos a determinados estímulos. } \\
\text { Feedback constante e apresentação do material em pequenos passos, respeitando o } \\
\text { ritmo do aluno. } \\
\text { Instrução programada. }\end{array}$ \\
\hline Avaliação & $\begin{array}{l}\text { Ocorre ao longo do processo de ensino-aprendizagem; inicia-se o curso com um pré- } \\
\text { teste a partir do qual todas as etapas seguintes serão planejadas e executadas segundo } \\
\text { um plano de ação. A avaliação final permite verificar se os comportamentos } \\
\text { desejados foram alcançados pelo aluno. }\end{array}$ \\
\hline Considerações finais & $\begin{array}{l}\text { Dá ênfase ao produto obtido, na transmissão cultural, na influência do meio, no } \\
\text { diretivismo, por parte do centro decisório, sobre o que será aprendido e o que deverá } \\
\text { ser transmitido às novas gerações. }\end{array}$ \\
\hline
\end{tabular}

Fonte: Mizukami (1996)

No quadro 3, apresentamos as concepções sobre a abordagem Humanista. Neste capítulo, a autora se pauta, principalmente, nas obras de Rogers (1972; 1978) e de Neill (1963).

Quadro 3 - Abordagem Humanista

\begin{tabular}{|l|l|}
\hline \multicolumn{1}{|c|}{ Categorias } & \multicolumn{1}{c|}{ Características } \\
\hline Características gerais & $\begin{array}{l}\text { enfoque predominantemente no sujeito com uma tendência interacionista na análise } \\
\text { do desenvolvimento humano e do conhecimento. } \\
\text { Principais representantes: C. Rogers e A. Neill. }\end{array}$ \\
\hline
\end{tabular}

\section{Continua}


conclusão

Quadro 3 - Abordagem Humanista

\begin{tabular}{|c|c|}
\hline Categorias & Características \\
\hline Homem & $\begin{array}{l}\text { O homem não nasce com um fim determinado, mas goza de liberdade plena e se } \\
\text { apresenta como um projeto permanente e inacabado. Não é um resultado, cria-se a si } \\
\text { próprio. }\end{array}$ \\
\hline Mundo & $\begin{array}{l}\text { É algo produzido pelo homem diante de si mesmo. Cria condições de expressão para } \\
\text { a pessoa, cuja tarefa vital consiste no pleno desenvolvimento de seu potencial } \\
\text { inerente. }\end{array}$ \\
\hline Sociedade-cultura & $\begin{array}{l}\text { Dá ênfase nos processo e não nos estados finais de ser e estaria orientada para a } \\
\text { "sociedade aberta", onde, segundo Popper (1974), os indivíduos assumem as } \\
\text { responsabilidades das decisões pessoais. }\end{array}$ \\
\hline Conhecimento & $\begin{array}{l}\text { Atribuído ao sujeito, onde, ao experienciar, conhece. Possui uma característica } \\
\text { dinâmica. }\end{array}$ \\
\hline Educação & $\begin{array}{l}\text { É centrada na pessoa, já que essa abordagem é caracterizada pelo primado do sujeito. } \\
\text { Passa a ser considerada tudo o que estiver a serviço do crescimento pessoal, } \\
\text { interpessoal ou intergrupal. }\end{array}$ \\
\hline Escola & $\begin{array}{l}\text { É o local onde se respeita a criança tal como é, oferecendo condições para que a } \\
\text { mesma possa desenvolver-se em seu processo de vir-a-ser. }\end{array}$ \\
\hline Ensino-aprendizagem & $\begin{array}{l}\text { A aprendizagem significativa é considerada por Rogers (1972) como a que envolve } \\
\text { toda a pessoa. Tem a qualidade de um envolvimento pessoal, sendo auto-iniciada } \\
\text { (motivação intrínseca). O lócus da avaliação reside no educando, que, ao verificar a } \\
\text { sua aprendizagem, permite ao mesmo, desenvolver a sua experiência como um todo. }\end{array}$ \\
\hline Professor-aluno & $\begin{array}{l}\text { O professor em si não transmite conteúdo, dá assistência, sendo um facilitador da } \\
\text { aprendizagem. }\end{array}$ \\
\hline Metodologia & $\begin{array}{l}\text { As técnicas audiovisuais, técnicas didáticas recursos, meios, mídias, etc., têm muito } \\
\text { pouca importância. Neste caso, a ênfase é dada à relação pedagógica, a um clima } \\
\text { favorável ao desenvolvimento das pessoas, ao desenvolvimento de um clima que } \\
\text { possibilite liberdade para aprender. }\end{array}$ \\
\hline Avaliação & $\begin{array}{l}\text { A avaliação praticada é a da autoavaliação, considerada por Rogers (1972), como um } \\
\text { dos melhores meios pelos quais "a aprendizagem autoiniciada se torna aprendizagem } \\
\text { responsável". }\end{array}$ \\
\hline Considerações finais & $\begin{array}{l}\text { A ênfase é no sujeito. } \\
\text { Os conteúdos vindos de fora passam a assumir importância secundária, e privilegia a } \\
\text { interação estabelecida entre as pessoas envolvidas em uma situação de ensino- } \\
\text { aprendizagem. }\end{array}$ \\
\hline
\end{tabular}

Fonte: Mizukami (1996) 
No quadro 4, vemos as concepções sobre a abordagem Cognitivista, em que a autora se baseia principalmente nos estudos de Jean Piaget (1896 - 1980) para descrever as principais concepções dessa abordagem. No contexto histórico em que surgem as obras de Piaget, Salvador et al. (2000, p. 249) afirma que

[...] a epistemologia estava dividida entre os que defendiam que o conhecimento era simplesmente uma cópia da realidade exterior e que era adquirido por meio dos sentidos - empirismo - e os que defendiam que o conhecimento era inato -inatismo. Nesse contexto, Piaget propõe uma terceira alternativa. Defendia que o conhecimento vai sendo construído - o seu conhecimento não é simplesmente uma cópia da realidade como os empiristas creem. Dá uma base empírica às suas preocupações epistemológicas e, por isso, interessa-se pela psicologia, sobretudo àquela que lhe permite seguir o processo de evolução dos conhecimentos ao longo da vida.

Por esse motivo, muitas das suas ideias vão ser estudadas graças às respostas que crianças de diferentes idades davam quando resolviam tarefas diversas. (SALVADOR et al., 2000, p. 249)

As ideias apresentadas a seguir, nos permitem vislumbrar parte das principais concepções de Piaget sobre o ensino, tendo como princípio que o conhecimento se processa através de uma natureza ativa presente no protagonismo do sujeito na aquisição de novos conhecimentos.

\begin{tabular}{|c|l|}
\hline \multicolumn{1}{|c|}{ Quadro 4- Abordagem Cognitivista } \\
\hline \multirow{2}{*}{ Características gerais } & $\begin{array}{l}\text { Cmplica, dentre outros aspectos, em se estudar cientificamente a aprendizagem como } \\
\text { sendo mais um produto do ambiente, das pessoas ou de fatores que são externos ao } \\
\text { aluno. } \\
\text { Representantes: Jean Piaget / Jerome Bruner. }\end{array}$ \\
\hline Homem + Mundo & $\begin{array}{l}\text { Homem e mundo são integrados, haja vista que segundo esta abordagem o } \\
\text { conhecimento é o produto da interação entre eles, entre sujeito e objeto, não se } \\
\text { enfatizando polo algum de relação. No seu desenvolvimento, o sujeito irá reinventar } \\
\text { todo processo racional da humanidade e, na medida em que ele reinventa o mundo, } \\
\text { caracterizado pela acoplagem do sistema simbólico à atividade real, o que lhe } \\
\text { possibilita pôr o pensamento a serviço da ação. }\end{array}$ \\
\hline
\end{tabular}


Continuação

Quadro 4 - Abordagem Cognitivista

\begin{tabular}{|c|c|}
\hline Categorias & Características \\
\hline Sociedade-cultura & $\begin{array}{l}\text { Não se tem um modelo ideal como produto final da sociedade humana. Busca-se, } \\
\text { através de intervenções, gerar desequilíbrios e, naturalmente, busca-se a superação do } \\
\text { mesmo em direção a um reequilíbrio. }\end{array}$ \\
\hline Conhecimento & $\begin{array}{l}\text { É visto como uma construção contínua. A passagem de um estado de } \\
\text { desenvolvimento ao seguinte é sempre caracterizada por formação de novas estruturas } \\
\text { que não existiam anteriormente no indivíduo. }\end{array}$ \\
\hline Educação & $\begin{array}{l}\text { Para Piaget, a educação é um todo indissociável, considerando-se dois elementos } \\
\text { fundamentais: o intelectual e o moral. } \\
\text { Visa à autonomia do aluno. }\end{array}$ \\
\hline Escola & $\begin{array}{l}\text { Tem a função de possibilitar ao aluno o desenvolvimento de suas possibilidades de } \\
\text { ação motora, verbal e mental, de forma que possa, posteriormente, intervir no } \\
\text { processo sociocultural e inovar a sociedade. Deve ser algo que possibilite ao aluno ter } \\
\text { um interesse intrínseco à sua própria ação. }\end{array}$ \\
\hline Ensino-aprendizagem & $\begin{array}{l}\text { A aprendizagem verdadeira se dá no exercício operacional da inteligência. Só se } \\
\text { realiza realmente quando o aluno elabora seu conhecimento. A aprendizagem, no } \\
\text { sentido estrito, se refere às aquisições relacionadas com informações e se dá no } \\
\text { decorrer do desenvolvimento. O ensino, nessa abordagem, está baseado em } \\
\text { proposição de problemas (projetos de ação ou operação que contenham em si um } \\
\text { esquema antecipador). }\end{array}$ \\
\hline Professor-aluno & $\begin{array}{l}\text { Ao aluno cabe um papel essencialmente ativo (a atividade é uma forma de } \\
\text { funcionamento do indivíduo) e suas atividades básicas; entre outras, deverão consistir } \\
\text { em: observar, experimentar, comparar, relacionar, analisar, justapor, compor, } \\
\text { encaixar, levantar hipóteses, argumentar etc. } \\
\text { E, ao professor, cabe orientar os alunos para que os objetivos sejam explorados pelos } \\
\text { mesmos, sem jamais oferecer-lhes a solução pronta. }\end{array}$ \\
\hline Metodologia & $\begin{array}{l}\text { Não existe um modelo pedagógico piagetiano. O que existe é uma teoria de } \\
\text { conhecimento, de desenvolvimento humano que traz implicações para o ensino. Uma } \\
\text { das implicações fundamentais é a de que a inteligência se contrói a partir da troca do } \\
\text { organismo com o meio, por meio das ações do indivíduo. } \\
\text { Um método elaborado segundo os princípios inerentes á abordagem em questão } \\
\text { implica programas, técnicas, horários suficientes flexíveis, adaptáveis às condições } \\
\text { dos alunos, respeitando o ritmo individual de trabalho, de assimilação do } \\
\text { conhecimento. }\end{array}$ \\
\hline Avaliação & $\begin{array}{l}\text { A avaliação terá de ser realizada a partir de parâmetros extraídos da própria teoria e } \\
\text { implicará verificar se o aluno já adquiriu noções, conservações, realizou operações, } \\
\text { realizações, etc. O rendimento deverá ser avaliado de acordo com a sua aproximação } \\
\text { a uma norma qualitativa pretendida. }\end{array}$ \\
\hline
\end{tabular}




\section{Conclusão}

Quadro 4 - Abordagem Cognitivista

\begin{tabular}{|c|l|}
\hline \multicolumn{1}{|c|}{ Categorias } & \multicolumn{1}{c|}{ Características } \\
\hline Considerações finais & $\begin{array}{l}\text { O conhecimento, para Piaget, progride mediante a formação de estruturas. } \\
\text { A ênfase é no processo cognitivo. }\end{array}$ \\
\hline
\end{tabular}

Fonte: Mizukami (1996)

Finalmente, no quadro 5, apresentamos a abordagem Sociocultural, pautada nos estudos de Paulo Freire. As obras consideradas pela autora são: Concientización (1974a), Uma educação para a Liberdade (1975), Pedagogia do Oprimido (1988), Educação como prática da Liberdade (1974b) e Educação. O sonho possível (1982).

Quadro 5 - Abordagem Sociocultural

\begin{tabular}{|c|c|}
\hline Categorias & Características \\
\hline Características gerais & $\begin{array}{l}\text { Enfatiza aspectos sócio-político-culturais. } \\
\text { Representante: Paulo Freire. } \\
\text { As obras de Paulo Freire consistem numa síntese de tendências como: o neotomismo, } \\
\text { o humanismo, a fenomenologia, o existencialismo e o neomarxismo. }\end{array}$ \\
\hline Homem + Mundo & $\begin{array}{l}\text { Homem e mundo são integrados, pois se trata de uma abordagem interacionista, } \\
\text { embora a ênfase seja dada ao sujeito como elaborador e criador do conhecimento. } \\
\text { O homem é visto como o sujeito inserido em um contexto histórico. } \\
\text { O homem é o ser da práxis, entendida como ação e reflexão dos homens sobre o } \\
\text { mundo, com o objetivo de transformá-lo. } \\
\text { O homem se constrói e chega a ser sujeito na medida em que, integrado em seu } \\
\text { contexto, reflete sobre ele e com ele se compromete, tomando consciência de sua } \\
\text { historicidade. }\end{array}$ \\
\hline Sociedade-cultura & $\begin{array}{l}\text { O homem cria a cultura na medida em que, integrando-se nas condições de seu } \\
\text { contexto de vida, reflete sobre ela e dá as respostas aos desafios que encontra. }\end{array}$ \\
\hline Conhecimento & $\begin{array}{l}\text { A elaboração e o desenvolvimento do conhecimento estão ligados ao processo de } \\
\text { conscientização. O conhecimento é elaborado e criado a partir do mútuo } \\
\text { condicionamento, pensamento e prática. Como processo e resultado, consiste ele na } \\
\text { superação da dicotomia sujeito-objeto. Conscientização implica e consiste, portanto, } \\
\text { em um contínuo e progressivo "des-velamento" da realidade. }\end{array}$ \\
\hline Educação & $\begin{array}{l}\text { Toda ação educativa, para que seja válida, deve, necessariamente, ser precedida tanto } \\
\text { de uma reflexão sobre o homem como de uma análise do meio de vida desse homem } \\
\text { concreto, a quem se quer ajudar para que se eduque. O homem se torna, nesta } \\
\text { abordagem, o sujeito da educação. }\end{array}$ \\
\hline
\end{tabular}




\section{Conclusão}

Quadro 5-Abordagem Sociocultural

\begin{tabular}{|c|c|}
\hline Categorias & Características \\
\hline Escola & $\begin{array}{l}\text { É um local onde seja possível o crescimento mútuo, do professor e dos alunos, no } \\
\text { processo de conscientização, o que implica uma escola diferente daquela em que } \\
\text { ocorre o ensino tradicional, com seus currículos e prioridades. } \\
\text { A escola, pois, para Paulo Freire (1974a), é uma instituição que existe num contexto } \\
\text { histórico de uma determinada sociedade. }\end{array}$ \\
\hline Ensino-aprendizagem & $\begin{array}{l}\text { Baseia-se na educação problematizadora ou conscientizadora, ou seja, aquela que } \\
\text { objetiva o desenvolvimento da consciência crítica e a liberdade como meios de } \\
\text { superar as contradições da "educação bancária", e responde à essência de ser da } \\
\text { consciência, que é a sua intencionalidade. } \\
\text { A dialogicidade é a essência desta educação. }\end{array}$ \\
\hline Professor-aluno & $\begin{array}{l}\text { A relação professor-aluno é horizontal e não imposta. } \\
\text { Há preocupação com cada aluno em si, com o processo e não com os produtos de } \\
\text { aprendizagem acadêmica padronizados. Os alunos participam do processo juntamente } \\
\text { com o professor. }\end{array}$ \\
\hline Metodologia & $\begin{array}{l}\text { Baseia-se no diálogo, ao mesmo tempo em que são oportunizadas a cooperação, a } \\
\text { união, a organização, a solução em comum dos problemas. Os alunos, pois, } \\
\text { participam do processo juntamente com o professor. } \\
\text { Portanto, a educação é entendida como um processo contínuo de tomada de } \\
\text { consciência e de modificação de si próprio e do mundo. }\end{array}$ \\
\hline Avaliação & $\begin{array}{l}\text { A verdadeira avaliação do processo consiste na autoavaliação e/ou avaliação mútua e } \\
\text { permanente da prática educativa por professor e alunos. Qualquer processo formal de } \\
\text { notas, exames, etc., deixam de ter sentido em tal abordagem. }\end{array}$ \\
\hline Considerações finais & $\begin{array}{l}\text { Esta abordagem contrapõe-se essencialmente do ensino tradicional e do ensino } \\
\text { decorrente da abordagem comportamental, principalmente pelos seus pressupostos } \\
\text { relativos a homem, mundo, educação etc. }\end{array}$ \\
\hline
\end{tabular}

Fonte: Mizukami (1996)

Essas abordagens são importantes, pois nos permitem ter uma visão ampla dos diversos tipos de ensino e de como os sujeitos do processo de ensino-aprendizagem interagem entre si, promovendo um aprendizado voltado apenas para a memorização, como, por exemplo, o ensino tradicional, ou um aprendizado voltado para a transformação do sujeito, libertando-o do caráter "oprimido", como é o caso da abordagem sociocultural. 
Também nos permitirá, no final das nossas discussões, compreendermos melhor porque os estudantes universitários, no nosso caso, estudantes de biologia, apresentam dificuldades em associar um conceito ao seu objeto de estudo.

\subsection{Aprendizagem no ensino superior: uma realidade possível}

A partir deste momento, voltaremos o nosso foco de atenção para o ensino superior, em especial, para a aprendizagem no ensino superior.

A universidade, em seu contexto histórico, surge como um "legado" da Idade Média, por volta do século XII (ANTUNHA, 1974; JANOTTI, 1992; MINOGUE, 1981; RANIERI, 2000; RASHDALL, $1936^{4}$ apud JANOTTI, 1992, p. 22).

A partir de então, ela busca manter-se em um mundo particular, dotada de privilégios mais ou menos uniformes ${ }^{5}$.

Snow (1995) comenta em sua obra "As duas culturas e uma segunda leitura" "que há uma polarização entre o mundo das ciências e das humanidades", ideia que é duramente criticada por Tony Becher (2001) em seu prefácio. Becher, motivado pela indignação à obra de Snow, mas, também influenciado pelos estudos do antropólogo Clifford Geertz (1983), busca traçar como se estabelecem as relações entre as tribos acadêmicas com os seus territórios de atuação profissional, através de um estudo etnográfico.

Neste trabalho, ele defende que em uma determinada disciplina as suas práticas habituais se correlacionam com as características de um domínio de investigação pertinente a mesma.

\footnotetext{
${ }^{4}$ Hastings Rashdall, The Universities of Europe in the Middle Ages, ed. F. M. Powicke e B. Emden, Oxford, 1936.

${ }^{5}$ Rashdall (1936, apud JANOTTI, 1992, op. cit., p. 26).
} 
Outra informação interessante que Becher (2001, p. 28 e ss.) destaca é que o conhecimento deriva do exame de como os sujeitos acadêmicos percebem o meio em que trabalham. Assim, ele acaba definindo que as atitudes, atividades e estilos cognitivos das comunidades científicas que representam uma determinada disciplina estão estreitamente ligados às características e estruturas dos campos de conhecimento com que essas comunidades estão profissionalmente comprometidas e, que, na concepção de "disciplina" ambos estão tão "inextrincavelmente conectados que qualquer intento em tentar imaginar uma divisão nítida entre eles resulta improdutivo".

Pensando no aspecto didático das relações que se estabelecem entre as tribos acadêmicas, Masetto (1992, p. 80) comenta que os estudantes universitários, em decorrência da sua idade (cronológica), muitas das vezes são vistos pelo(s) professor(es) universitário(s) como "jovens" e, em sua maioria, "inexperientes”, com "exceção daqueles com uma idade mais avançada e ocupação profissional definida, visto por muitos como adultos”. Assim sendo, os “cursos elaborados pelos professores passam a ter um caráter de $2^{\circ}$ grau", no sentido de que

[...] os professores trazem para si toda a responsabilidade de elaborar o currículo do programa, dão as aulas, preparam as apostilas, corrigem os trabalhos e os exercícios, orientam, guiam, dirigem, avaliam, dão a nota, aprovam e reprovam. Por sua vez, o aluno apena ouve, vê, estuda, anota, faz os exercícios e as provas, assiste às aulas. É pouco ativo, pouco participante, quase nada responsável ou responsabilizado pela sua aprendizagem. (MASETTO, 1992, p. 80)

Por sua vez, Chauí (2003, p. 11), defende a ideia de que

[...] a educação significa um movimento de transformação interna daquele que passa de um suposto saber (ou da ignorância) ao saber propriamente dito (ou à compreensão de si, dos outros, da realidade, da cultura acumulada e da cultura no seu presente ou se fazendo). (CHAUÍ, 2003, p. 11) 
Aos poucos, podemos perceber que o caráter aprendizagem no ensino superior está firmemente vinculado à figura do professor (um misto de pesquisador e divulgador dos conhecimentos científicos por meio dos veículos de transmissão acadêmica - simpósios, congressos, publicações científicas e também através da formação de outros profissionais - as disciplinas acadêmicas).

Levinas (1998, p. 25), ao comentar a sua percepção sobre educação, defende a ideia de que

\begin{abstract}
A educação, fortemente determinada pelos saberes, reflete de fato um estado do conhecimento, mas, por sua vez, constitui um elemento condicionante das atividades cognitivas do indivíduo. Geralmente, o âmbito da educação não é produtor de saberes, na medida em que o conhecimento humano e as próprias manifestações culturais não se dão e nem se desenvolvem em si mesmas apenas como reprodução. (LEVINAS, 1998, p. 25)
\end{abstract}

Assim, o autor propõe que o ensino oferece duas disposições contraditórias. De um lado, uma superestimação da capacidade de incorporar e assimilar teorias que historicamente tem sido dificultosamente adotada e requerem enormes esforços intelectuais, e por outro lado, uma atitude de subestimação da capacidade do indivíduo para adotar ideias próprias e para formular hipóteses por si mesmo. Ambas disposições estão ligadas a elementos coercitivos e restritivos que atenuam o papel ativo que poderia e deveria assumir o sujeito da aprendizagem. Ambas as disposições se encontram comprometidas com sutis mecanismos que levam a uma incorporação de ideias fundadas em uma passiva receptividade e que reproduzem em outros níveis de cognição: também na atividade científica se pode atuar sem questionamentos, confiar incondicionalmente nas teorias. A respeito de qualquer teoria científica, pode existir uma atitude de submissão a certos pressupostos e a certas pautas sem que necessariamente estes pressupostos tenham sido incorporados de maneira crítica ou consciente. 
Finalmente, para Levinas (1998, p. 27)

Em todos os casos, o papel dos pressupostos é determinante, e os processos para que os indivíduos sejam instruídos a respeito desses pressupostos resultam cruciais na hora de determinar como são e como se ativam os mecanismos que permitem a adoção de novas ideias que, geralmente, se opõem a um pensamento natural ou ao senso comum. (LEVINAS, 1998, p. 27)

Buscando identificar características ou condições de aprendizagem numa pessoa adulta, Masetto (1992, p. 80-83) elenca algumas pesquisas citadas por Brookfield (1986): Simpson (1980), (Gibb 1960), Miller (1964), Brudage e Macheracher (1980), que demonstram que o adulto busca aprender através da sua experiência pessoal. Também comenta que, para que a aprendizagem ocorra, existem alguma condições:

- A aprendizagem precisa ser significativa para o sujeito;

- Os objetivos precisam ser definidos e perseguidos pelos aprendizes, e estes precisam contar com o feedback a respeito do seu trabalho em direção aos objetivos;

- Há a necessidade de motivação adequada para mudarem o seu comportamento;

- Os feedbacks positivos funcionam como um reforço para consecução de maior aprendizagem;

- Evite prescrever um único modo de aprender, haja vista que cada um possui um estilo próprio de aprendizagem.

Masetto (2003, p. 36 e ss.), então defende a ideia de que os processos de ensino e de aprendizagem são diferentes. De modo geral, a ênfase dada pela docência universitária ainda recai sobre o "processo de ensino", fazendo com que a organização curricular se torne estanque, as disciplinas são maximamente conteudísticas com pouca abertura para a interdisciplinaridade e também há pouco incentivo à investigação científica na graduação. A metodologia, por sua vez, está centrada na transmissão ou comunicação oral de temas ou 
assuntos acabados por parte dos professores (aulas expositivas), ou leitura de livros e artigos e sua repetição em classe. Predomínio de um programa a ser cumprido. A avaliação é usada para averiguação do que foi assimilado do curso mediante provas tradicionais e notas classificatórias e aprobatórias ou não.

O corpo docente é visto, neste caso, como um grupo constituído por mestres e/ou doutores, competentes na comunicação do conhecimento, que são recrutados para "ensinar aos que não sabem”.

Por outro lado, quando a ênfase universitária se apoia nos processos de aprendizagem, acontece o contrário, ou seja, o foco de atenção deixa de ser o professor e passa a ser o aluno. Então, segundo o autor, podemos perceber que a aprendizagem passa a ser vista como um processo de crescimento e desenvolvimento de uma pessoa em sua totalidade, abarcando minimamente quatro grandes áreas: a do conhecimento, a do afetivo-emocional, a de habilidades e de atitudes com valores.

A ênfase no processo de aprendizagem traz consequências sérias e de grande repercussão, entre elas:

a) a organização curricular, através de um currículo flexível, voltado para o aprendera-aprender ao invés da pretensão de transmitir a totalidade de conhecimentos atuais;

b) na contratação do corpo docente, onde investe-se na formação pedagógica do professor, unindo saber acadêmico com o profundo conhecimento dos processos de aprendizagem;

c) metodologia em sala de aula - dialogada, com a participação efetiva de professores e alunos;

d) Resulta em uma aprendizagem significativa, como a defendida por Ausubel (1963; 1968) onde há três vantagens da aprendizagem significativa sobre a memorística. Em primeiro lugar, o conhecimento que se adquire de maneira significativa é retido e lembrado por mais 
tempo. Em segundo lugar, aumenta a capacidade de aprender outros materiais ou conteúdos relacionados de uma maneira mais fácil, mesmo se a informação original for esquecida. Em terceiro lugar, e uma vez esquecida, facilita a aprendizagem seguinte a - "reaprendizagem", para dizê-lo de outra maneira;

e) Resulta também na aprendizagem continuada (lifelong learning) entendida com um processo pelo qual se faz presente a necessidade de uma tomada de consciência dos nossos alunos pela busca contínua do conhecimento e do seu aprimoramento profissional.

Então, pelo o que observamos na fala dos pesquisadores citados, o aprendizado para que ocorra no ensino superior, precisa em primeiro lugar, verificar sobre qual abordagem de ensino ele está pautado e depois, buscar-se, na medida do necessário, a sua reestruturação para que o sujeito da aprendizagem tenha uma formação holística, ou seja, uma formação voltada para o todo, buscando auxiliar o estudante a aprender segundo os quatro pilares da educação, citados pela Unesco (1998): aprender a conhecer, aprender a fazer, aprender a viver juntos, aprender a viver com os outros e aprender a ser (DELORS, 2003). 


\section{Capítulo 2. Os conceitos de flor e de fruto no ensino superior}

A eficácia máxima da comunicação não é alcançada senão quando a mensagem é compreendida pelo receptor. Abraham Moles (1970) em L'Affiche dans la Société Urbaine.

O que vêm a ser flor e fruto? Dentro da Biologia, uma definição científica. Mas, o que podemos entender por definição científica?

Segundo Fourez (1995, p. 46), para definirmos um objeto, "utilizamos sempre um esquema teórico admitido". Ou seja, "uma definição, em geral, é a releitura de um certo número de elementos do mundo por meio de uma teoria; é portanto uma interpretação". Assim, a definição de uma flor em biologia não é um "ponto de partida", mas "resultado de um processo interpretativo teórico".

Como aponta Factor \& Kooser (s.d., apud FOUREZ, 1995), os processos teóricos tendem a dar-nos "objetos científicos padronizados". Desta maneira, não encontramos "o" objeto estudado, observado, analisado, mas, sim tal ou tal objeto diferente um do outro. Neste sentido, passamos a usar "modelos" ou "teorias" para substituir o objeto concreto.

Em relação à flor e ao fruto, esse processo não é diferente. Muito pelo contrário, nos utilizamos de "objetos científicos padronizados" para explicar "a" flor e "o" fruto. No entanto, ao tentarmos padronizar um determinado objeto, através da observação sistemática, também teremos que enfrentar outro problema, que é o da "equivalência" do "mesmo" e do "outro", como dizia Platão. Ou seja, ao estabelecer uma relação entre dois objetos semelhantes, como, por exemplo, duas bananas (ou uma banana semelhante às outras), supõe que se estabeleceu 
uma relação de equivalência entre esses dois "objetos" diferentes. Assim, podemos afirmar pautados em Fourez (1995, p. 47) que obsevar é estabelecer, “em nome de uma percepção e de critérios teóricos, relações de equivalência entre o que eu poderia também considerar como diferente". Então, a "semelhança" não é aceita de modo passivo na observação, mas decidida segundo uma visão teórica, ou seja, “a semelhança não é jamais dada, ela é imposta à nossa estruturação teórica porque a julgamos prática".

Assim sendo, quando falamos de um objeto estamos sempre o situando em um universo convencional de linguagem. Ou seja, falar de objeto significa inseri-lo em um contexto cultural, dando-lhe um caráter institucional. Para Mayr (2008, p. 96), no caso da biologia, ao falarmos de uma teoria, geralmente estamos nos baseando em "conceitos", bem diferentemente das ciências físicas, em que a formação de teorias, geralmente se dá através de "leis". Portanto, uma definição científica ou um modelo científico, nada mais é do que uma construção social relativa a uma cultura e a seus projetos.

\subsection{O conceito de flor no ensino superior}

Em relação ao conceito de flor, na literatura voltada para o ensino superior, não há um consenso sobre a qual grupo ela pertenceria, exclusivamente, se é que isso seja possível. Em relação ao termo flor, as implicações em definirem o grupo ao qual ela faz parte é algo mais complexo do que se imagina. Porém, o que existe, e isso se faz necessário ser observado, é uma "tolerância" entre os pesquisadores/autores no sentido de que, enquanto não se consegue dados suficientes para se caracterizar melhor os grupos taxonômicos dos vegetais (senso amplo), trabalha-se com a hipótese de que as flores ainda são "uma característica típica do grupo das angiospermas" (MENEZES et al., 2004; JUDD et al., 2009; RAVEN, EVERT, 
EICHHORN, 2001). Judd et al. (2009, p. 175) comenta essa questão afirmando que o que difere as angiospermas das outras espermatófitas é justamente "o arranjo particular das partes constituintes da flor neste grupo". Não vamos nos aprofundar no mérito da questão, pois o que nos interessa neste momento é buscarmos o conceito de flor e de fruto. Neste sentido, flor e as suas estruturas são descritos por Judd et al. (2009, p. 61-62) como

[...] um ramo altamente modificado portando apêndices especializados (folhas modificadas). O ramo modificado (ou eixo floral) é chamado de receptáculo, o pedúnculo floral é chamado de pedicelo. As flores geralmente nascem na axila de uma folha mais ou menos modificada, ou bráctea, estruturas menores e foliáceas, as bractéolas, muitas vezes distribuem-se ao longo do pedicelo.

As flores possuem até três partes principais: perianto (estruturas mais externas; protetoras e/ou coloridas), androceu (estruturas produtoras de pólen) e gineceu (estruturas produtoras de óvulos). As flores que possuem as três partes são chamadas de completas, enquanto as flores que pelo menos uma dessas partes está ausente são chamadas de incompletas. Se tanto o androceu como o gineceu estão presentes, a flor é chamada de bissexual (ou perfeita), mas, se um deles está faltando, a flor é chamada de unissexual (imperfeita). Neste último caso, ela pode ser estaminada, se apenas o androceu está presente, ou carpelada, se apenas o gineceu está presente. Em espécies monoicas, um mesmo indivíduo apresenta tanto flores estaminadas quanto flores carpeladas, enquanto que em espécies dioicas as flores estaminadas e carpeladas ocorrem em indivíduos diferentes. Espécies polígamas possuem tanto flores unissexuais como bissexuais (estaminadas e/ou carpeladas) na mesma planta. (JUDD et al., 2009, p. 61-62) (destaque dos autores)

Na sequência Judd et al. (ibid., p. 62) descreve em maiores detalhes as três partes constituintes de uma flor completa. Vejamos:

O perianto é sempre a porção mais externa de uma flor, seguida em quase todas as flores pelo androceu, e com o gineceu disposto no centro da flor. As partes do perianto podem ser indiferenciadas entre si, sendo, neste caso, o perianto composto por tépalas. Alternativamente, o perianto pode estar diferenciado em duas partes principais, e assim é formado por um verticilo mais externo (em disposição cíclica ou espiralada) de sépalas, chamadas conjuntamente de cálice, e um verticilo mais interno (também em disposição cíclica ou espiralada) de pétalas, chamadas conjuntamente de corola. 
As sépalas geralmente protegem as partes internas da flor quando em botão; as pétalas são em geral coloridas e atuam como elementos atrativos para polinizadores [...].

O androceu compreende o conjunto de estames de uma flor. Os estames são usualmente diferenciados em antera e filamento, embora, em alguns casos, sejam petaloides e sem distinção entre essas duas partes. Cada antera geralmente contém quatro sacos polínicos, ou microsporângios, que estão organizados em dois pares. Os sacos polínicos estão aderidos entre si e o filamento pelo conectivo, que é ocasionalmente expandido e forma apêndices variados ou de um tecido estéril conspícuo que separa os sacos polínicos.

As células dos sacos polínicos sofrem um processo de meiose, que resulta na produção de grãos de pólen. (gametófitos masculinos, ou microgametófitos). Por essa razão, o androceu é comumente referido como a "porção masculina" de uma flor. Obviamente, as flores, como parte de uma planta diplóide (ou esporófito), não podem ser referidas como masculinas (ou femininas) porque o esporófito está envolvido apenas na produção de esporos (processo associado à meiose). [...]

O gineceu compreende todos os carpelos de uma flor. O carpelo é o sítio de polinização e fertilização em uma planta. Estruturalmente, os carpelos são tipicamente formados pelo estigma, que coleta e facilita a germinação do pólen trazido pelo vento, pela água ou por animais variados; pelo estilete, uma porção do carpelo geralmente estreita e tubular especializada para o crescimento do tubo polínico; e pelo ovário, a porção mais basal e alargada do carpelo que envolve e protege os óvulos.

Cada óvulo contém um megagametófito (gametófito feminino, ou saco embrionário), que produz um gameta e é geralmente provido de duas camadas protetoras denominadas tegumentos. O óvulo encontra-se conectado ao ovário por um pedúnculo chamado funículo. O gineceu é em geral chamado de "porção feminina" da flor, embora essa denominação seja tecnicamente incorreta [...]. (JUDD et al., 2009, p. 62) (destaque dos autores)

Os pesquisadores/autores, aos descreverem um objeto de estudo, geralmente disponibilizam algumas imagens com descrições das suas estruturas e/ou descrevem os processos pelos quais se manifestam. No caso da flor, propriamente dita, o que ocorre é apresentarem a descrição de uma "flor completa" em detalhes (como o descrito acima por JUDD et al. 2009) e depois inserem uma imagem (geralmente um esquema colorido ou não) das partes constituintes de uma flor e do ciclo reprodutivo das angiospermas (figuras 1 e 2). 


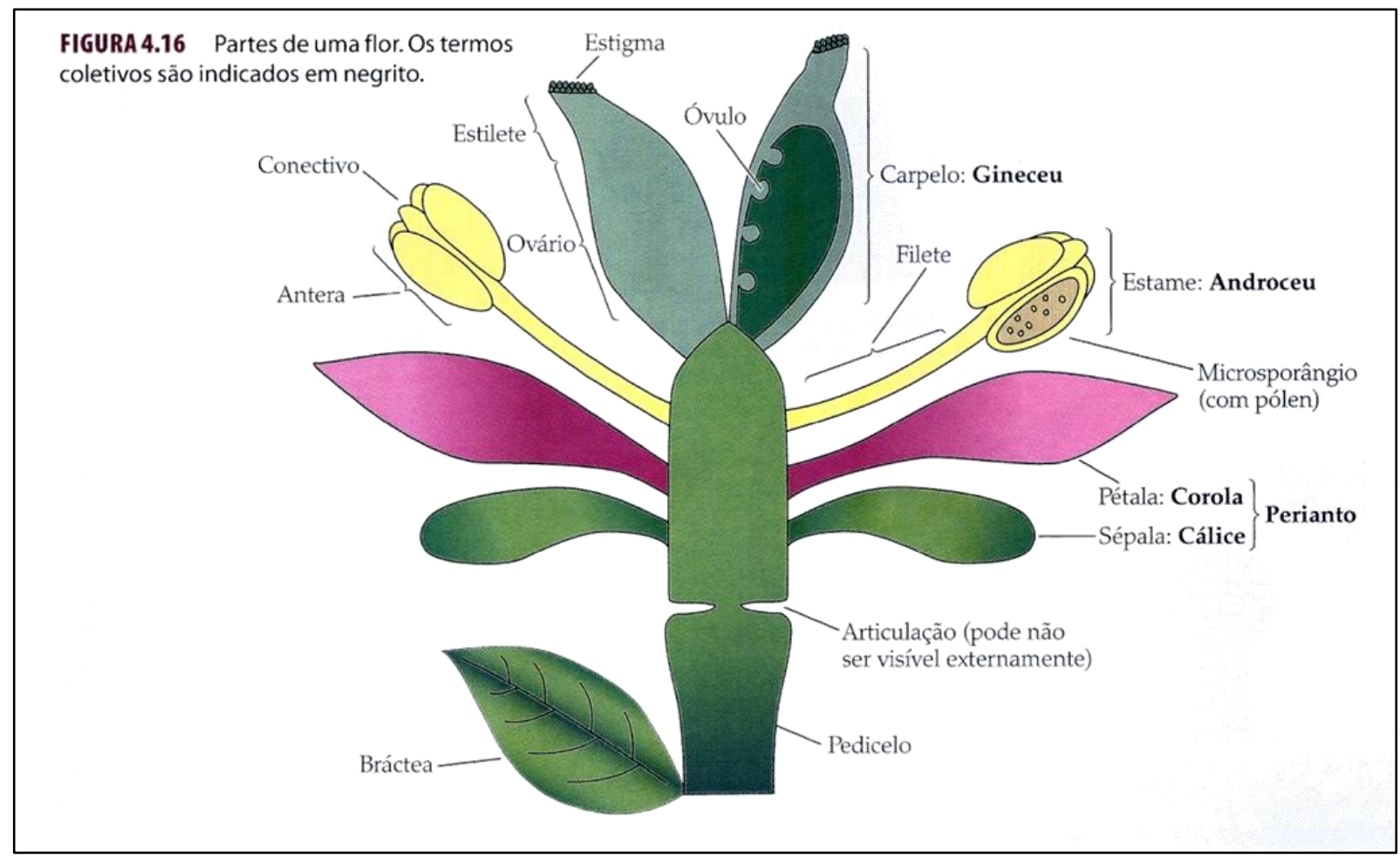

Figura 1. Representação didática ilustrando uma flor completa e suas partes constituintes. (Fonte: Judd et. al. 2009, p. 62)

No caso da Fig. 1, podemos perceber que o esquema, por mais próximo que seja da realidade de uma flor completa, não poderá suprir a demanda dos estudantes em analisar e identificar outras categorias de flores, pois na biologia, como dizemos, "para toda regra, sempre há uma exceção”. E neste caso da flor, são várias as exceções. Para amenizar essa questão, alguns autores procuram incluir na sequência do esquema uma ilustração com uma foto de uma flor (completa) e a identificação de suas partes, como, por exemplo, nas obras Biologia Vegetal (RAVEN, EVERT, EICHHORN, 2001) e Fisiologia Vegetal (TAIZ, ZEIGER, 2009).

No caso da figura 2, os livros voltados para o ensino superior apenas representam o ciclo de vida das angiospermas por meio de esquemas, haja vista as sutilezas dos esquemas e também a adequação dos conteúdos a uma realidade "palatável” aos leitores. 


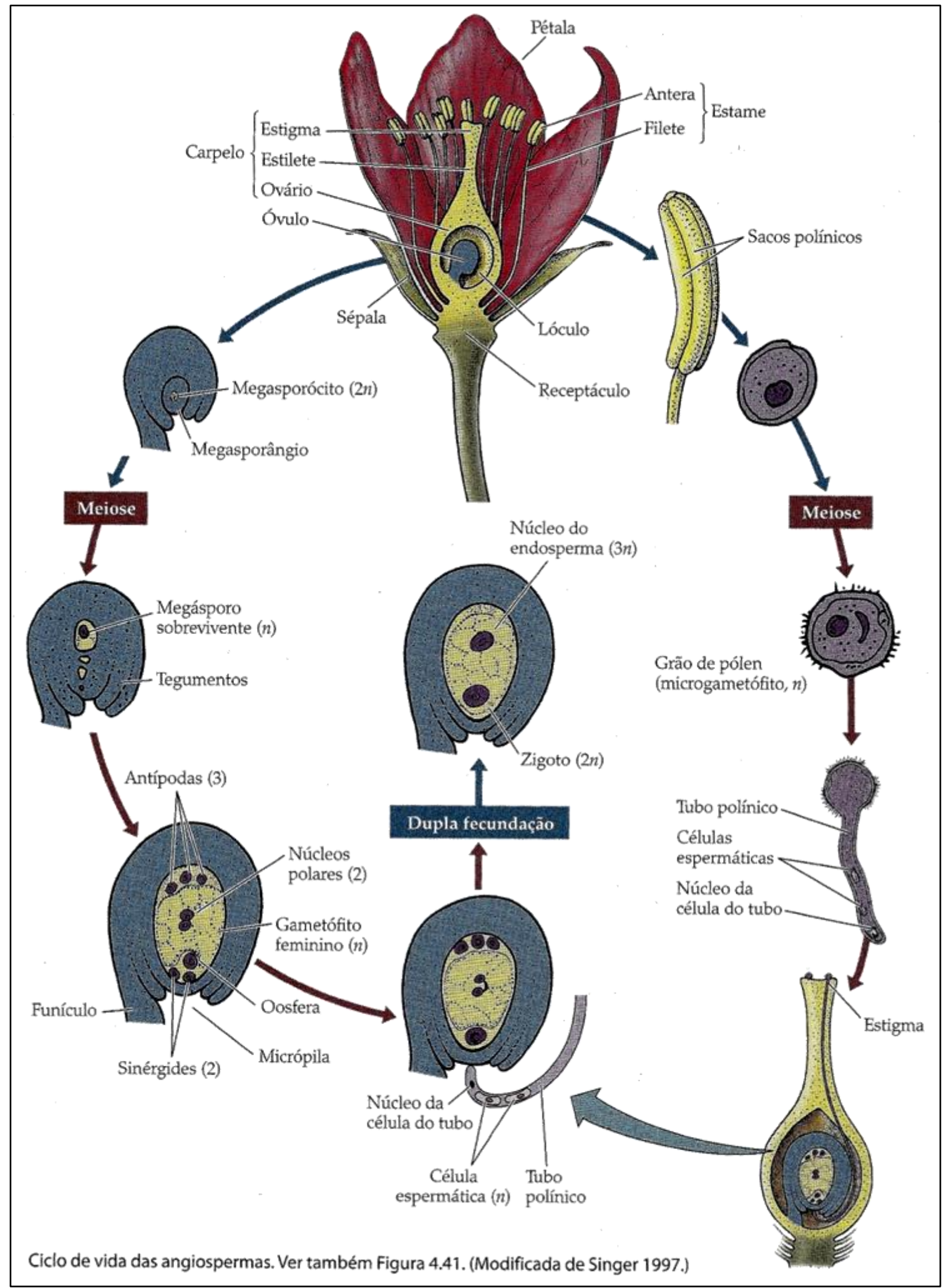

Figura 2. Esquema didático do ciclo vital das angiospermas (Fonte: Judd et. al. 2009, p. 63) 
O conceito de flor também está diretamente ligado a outro conceito, o de inflorescência (Fig. 3), o qual é citado como sendo "o sistema caulinar que atua na formação de flores e é modificado apropriadamente para esta função" (TROLL, 1964, apud JUDD et al. 2009, p. 72). O estudo de uma inflorescência, como destaca Judd et al. (2009) é de suma importância no trabalho do taxonomista tanto quanto a determinação de relações filogenéticas. Isso porque lhe permite diferenciar, identificar e classificar as espécies dentro de seus grupos. Judd et al. (2009, p. 72-75), depois procede com as descrições dos dois principais tipos de inflorescências: monotélicas e politélicas, comenta os subgrupos de cada uma delas. Assim sendo, as monotélicas subdvidem-se em: cimeira, cimeira paniculada, cimeira racemosa, cimeira alongada, cimeira helicoidal, cimeira escorpioide, capítulo e umbela (alguns dos tipos mais comuns). Já as politélicas subdvidem-se em: racemo, panícula, umbela, espiga, capítulo, corimbo, fascículo e espádice com espata (alguns dos tipos mais comuns).

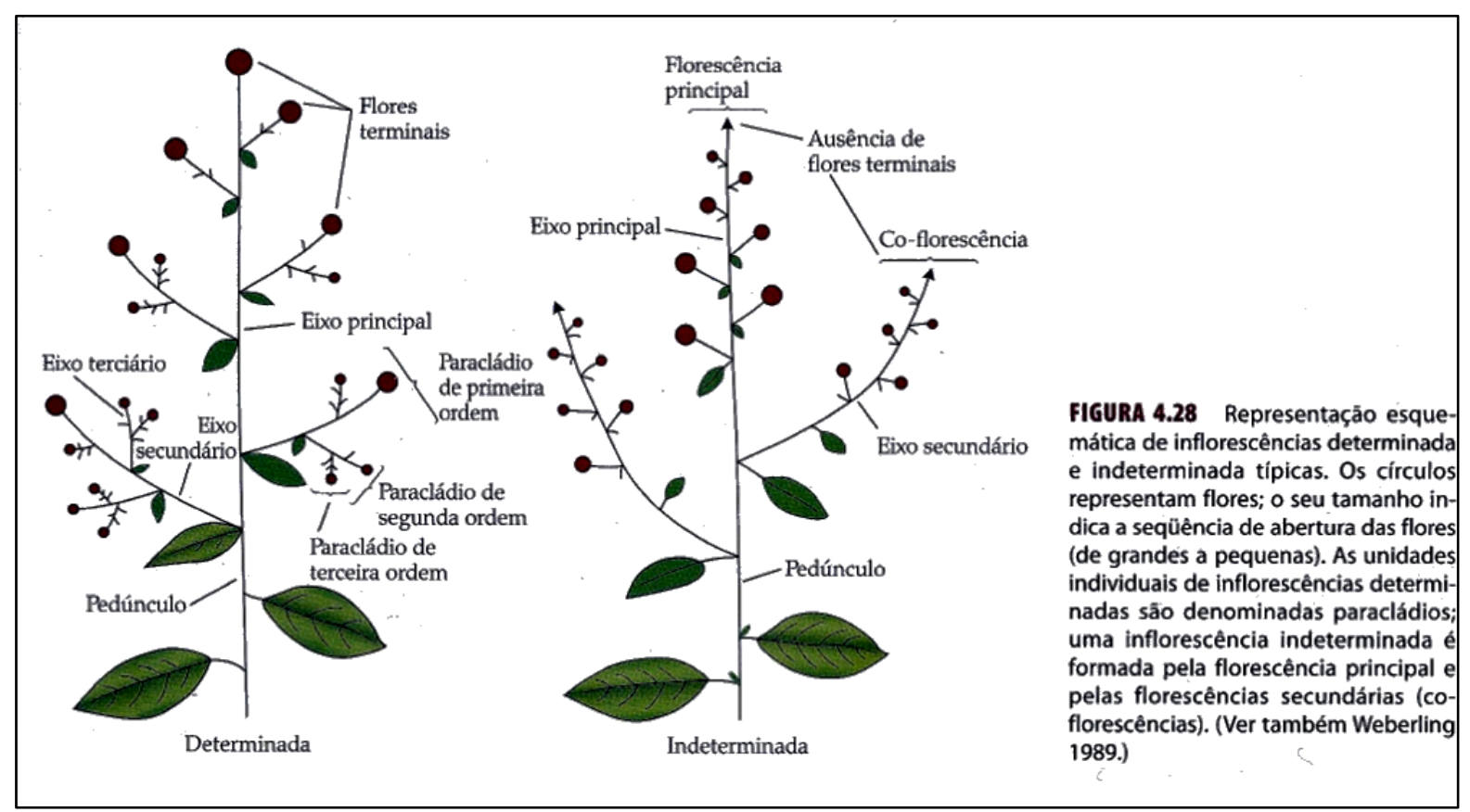

Figura 3. Esquema didático de inflorescência (Fonte: Judd et. al. 2009, p. 73) 
Os esquemas de inflorescências não se restringem apenas a esses dois modelos. Dentre as inflorescências determinadas e indeterminadas há diversas categorias que são representadas por outros esquemas (vide JUDD et. al., 2009).

\subsection{O conceito de fruto no ensino superior}

O conceito de fruto, também defendido como exclusivo das angiospermas, é definido por Judd et al. (2009, p. 75) como sendo "o ovário maduro, juntamente com suas estruturas acessórias (hipanto ou partes do perianto)". Assim como no caso das flores, os frutos também podem ser classificados, mas, como salienta Judd et al. (2009, p. 75), "toda e qualquer sistema de classificação de frutos tem de lidar com dificuldades consideráveis”. Dentre elas, os autores destacam as variações observadas continuamente na estrutura do fruto.

Dentre os vários tipos de frutos (classificação artificial), podemos destacar: aquênio, baga, cápsula, cápsula indeiscente, cariopse (grão), drupa, drupa deiscente, esquizocarpo, folículo, legume e o lomento, entre outros.

Assim como ocorre com as flores, tanto em inflorescências como em frutos, os autores costumam colocar fotos dos arranjos florais e dos tipos de frutos. Na sequência, temos uma figura (4) retirada da abra do Judd et al. (2009, p. 77), através da qual estão exemplificados alguns esquemas de frutos, muito comuns em diversos livros. 


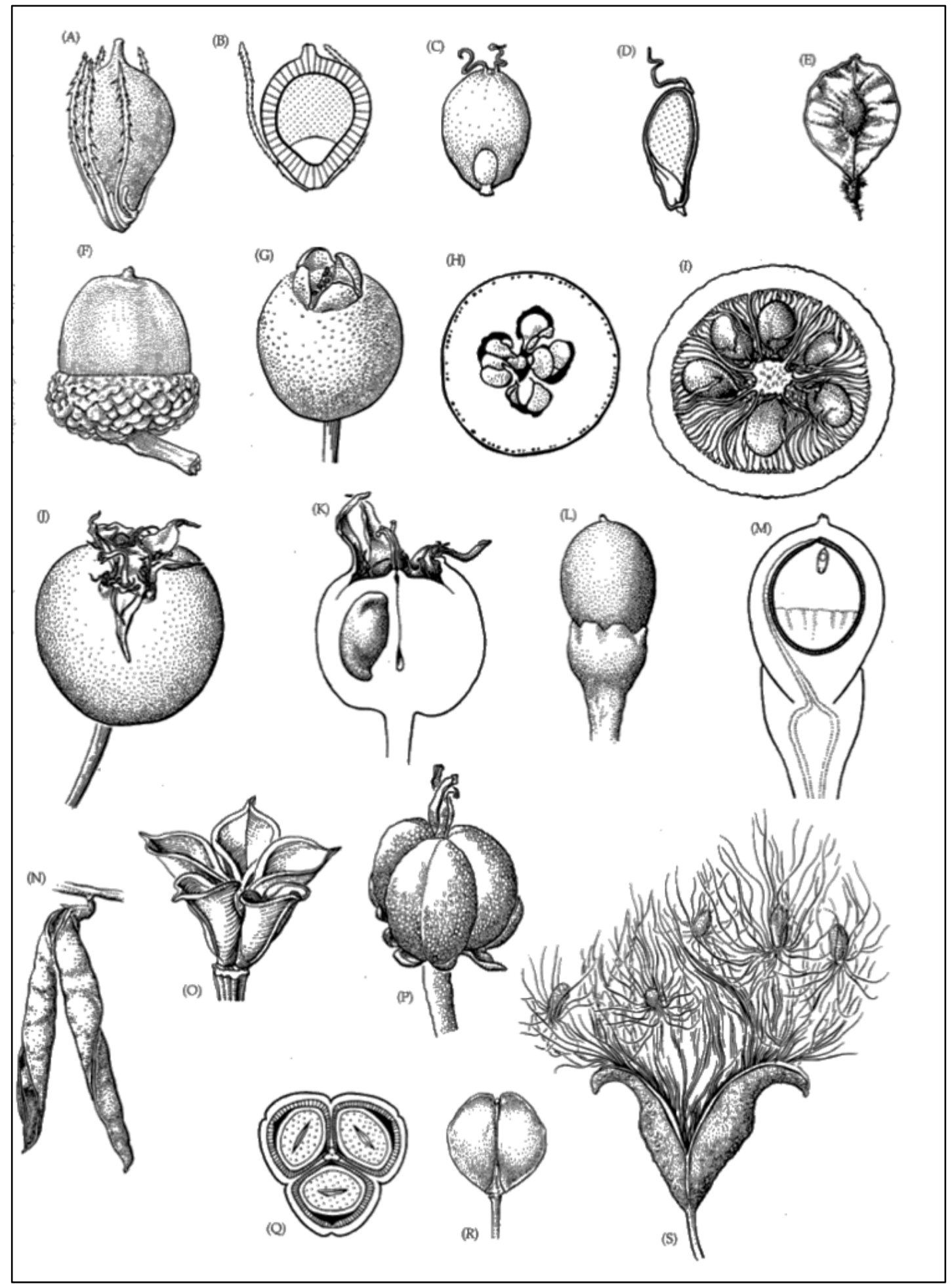

Figura 4. Esquema didático de tipos de fruto (Fonte: Judd et. al. 2009, p. 77). 
Em relação ao esquema de fruto apresentado acima, temos um trabalho artístico que busca se aproximar ao máximo possível da realidade. Mas, a imagem está em preto e branco, não apresenta escala, entre outros fatores que dificultam o reconhecimento destas estruturas e suas variações em outros exemplares.

\subsection{Considerações finais}

Em ambos os casos, o aluno precisa, além de adequar o seu conhecimento sobre flor e fruto (senso comum), também tem que fazer a adequação da linguagem e da realidade científica apresentada nestes esquemas para uma realidade acadêmica, uma vivência que ele vislumbra em sala de aula através de aulas expositivas e de práticas de laboratório, ou seja, uma imersão total em valores, conceitos e atitudes que até o seu ingresso no ensino superior, lhe eram desconhecidos.

Fora essas questões como vimos inicialmente, os modelos apresentados de flor e de fruto, buscam trazer ao leitor em geral, um exemplo do que seria a "realidade". Mas, neste caso, essa 'realidade', em muitas vezes, não é contemplada pelos esquemas, pela linguagem iconográfica, fazendo com o que o aluno desenvolva uma ideia, muitas das vezes, "errada" do processo, do fenômeno estudo, e neste caso, do conceito a ser apreendido. 


\title{
Capítulo 3. Materiais e Métodos
}

\begin{abstract}
A tarefa do pesquisador é [...] desvelar os diferentes níveis de universidade e particularidade confrontados em um caso específico - o que é largamente universal, o que é generalizável a outras situações, o que é peculiar a esse caso [...] Portanto, a preocupação primordial da pesquisa interpretativa é particularização ao invés de generalização. (ERICKSON, 1986, p. 130)
\end{abstract}

Neste capítulo apresentaremos a estrutura da pesquisa e também discutimos as ferramentas de análise de conteúdo apresentada por Laurence Bardin (2008).

\subsection{Os questionários e os testes}

Ao longo da nossa pesquisa, foram aplicados três questionários, com pequenas alterações em cada um. Procuramos adequá-los às realidades as quais os sujeitos da aprendizagem estavam familiarizados para, consequentemente, podermos traçar paralelos entre as suas "falas" e os "discursos", aos quais os mesmos se reportam para trazer à tona os conceitos morfológicos de flor e de fruto (senso amplo). Além disso, aplicamos juntamente com cada um dos questionários, três testes de confrontação, sendo cada um composto por pranchas coloridas onde os alunos tinham que aplicar os conceitos morfológicos de flor e de fruto.

Por isso, no primeiro questionário, a nossa preocupação foi a de levantarmos informações sobre a formação escolar antes do ingresso no Curso de Ciência Biológicas da USP (CBio/USP/2006), a partir do ensino médio. 
Neste sentido, o primeiro questionário $(\mathrm{Q} 1)^{6}$ (tab. 1), foi aplicado no primeiro dia de aula da Disciplina Fauna, Flora e Ambiente - 0410109 (FFA/0410109), 1º semestre/2006, coincidindo com o primeiro dia de aula dos ingressantes do CBio/USP/2006. Propositalmente, ele está dividido em duas partes, sendo a primeira voltada para as influências dos outros sobre a formação conceitual (Q1q1, Q1q2, Q1q3, Q1q4, Q1q5, Q1q6, Q1q7, Q1q8 e Q1q11) e, em segundo momento, qual a fala dos sujeitos da aprendizagem sobre os conceitos biológicos analisados (Q1q9, Q1q10, Q1q12 e Q1q13). Então, temos o seguinte:

Tabela 1 - Itens e eixos investigativos relacionados ao primeiro questionário (Q1)

\begin{tabular}{ll}
\hline Item & \multicolumn{1}{c}{ Assunto Abordado pela Questão } \\
\hline Q1q1 & Escola Pública ou Privada \\
Q1q2 & Nome da Instituição \\
Q1q3 & Primeira Formação Superior \\
Q1q4 & Adoção de Material Pedagógico de Biologia pela Instituição que frequentou \\
Q1q5 & Tipos de Materiais Pedagógicos adotados \\
Q1q6 & Aula de Botânica no ensino médio \\
Q1q7 & Aula sobre flor no ensino médio \\
Q1q8 & Fez Cursinho \\
Q1q9 & Aplicação do conceito de flor (reconhecer) \\
Q1q10 & Conceito de flor (discurso) \\
Q1q11 & Aula sobre fruto no ensino médio \\
Q1q12 & Aplicação do conceito de fruto (reconhecer) \\
Q1q13 & Conceito de fruto (discurso) \\
\hline
\end{tabular}

O primeiro teste $(\mathrm{T} 1)^{8}$, que acompanhou o primeiro questionário, foi aplicado para que possamos confrontar os conceitos expressos pelos sujeitos da aprendizagem no questionário (Q1q10 e Q1q13) com a sua aplicação, quando solicitamos na primeira questão (T1q14), que os sujeitos identifiquem nas pranchas (T1q14p1, T1q14p2, T1q14p3, T1q14p4, T1q14p5 e

\footnotetext{
${ }^{6}$ Vide Anexo A.

${ }^{7}$ Os dados desta questão foram suprimidos dos resultados por questões de Ética.

${ }^{8}$ Vide Anexo $\mathrm{B}$.
} 
T1q14p6) o que eles acreditam ser uma flor; e, na segunda questão (T1q15), que os sujeitos identifiquem nas pranchas (T1q15p1, T1q15p2, T1q15p3, T1q15p4 e T1q15p5) o que eles acreditam ser um fruto.

O segundo Questionário $(\mathrm{Q} 2)^{9}$ (tab. 2), aplicado no primeiro semestre/2007, por sua vez, no primeiro dia de aula da Disciplina Morfologia e Anatomia de Vasculares/BIB-0121 (MAPV/0121), também está dividido em duas partes, mas, neste momento, a nossa preocupação maior era apenas confirmar se os estudantes (ingressantes do CBio/USP/2006) tiveram algum contato com os conceitos biológicos que estamos enfocando durante esse período de permanência na USP (Q2q1, Q2q2 e Q2q3); e, havendo contato com os conceitos assinalados, verificar se ocorreram alterações no discurso dos alunos em relação aos conceitos morfológicos de flor e de fruto (Q2q4, Q2q5, Q2q6 e Q2q7). Sendo assim, temos:

Tabela 2 - Itens e eixos investigativos relacionados ao segundo questionário (Q2)

\begin{tabular}{ll}
\hline Item & \multicolumn{1}{c}{ Assunto Abordado pela Questão } \\
\hline Q2q1 & Segundo ano no Curso de Ciências Biológicas \\
Q2q2 & Disciplinas que já abordaram os conceitos de flor e de fruto \\
Q2q3 & Estágio em que teve contato e fez uso dos conceitos de flor e fruto \\
Q2q4 & Aplicação do conceito de flor (reconhecer) \\
Q2q5 & Conceito de flor (discurso) \\
Q2q6 & Aplicação do conceito de fruto (reconhecer) \\
Q2q7 & Conceito de fruto (discurso) \\
\hline
\end{tabular}

O segundo teste $(\mathrm{T} 2)^{10}$, que acompanhou o segundo questionário, foi aplicado para que possamos confrontar os conceitos expressos pelos sujeitos da aprendizagem no questionário (Q2q5 e Q2q7) com a sua aplicação (em tese), quando solicitamos na primeira questão (T2q8), que os sujeitos identifiquem nas pranchas (T2q8p1, T2q8p2, T2q8p3, T2q8p4, T2q8p5 e T2q8p6) o que eles acreditam ser uma flor; e, na segunda questão (T2q9), que os

\footnotetext{
${ }^{9}$ Vide Anexo C.

${ }^{10}$ Vide Anexo D.
} 
sujeitos identifiquem nas pranchas (T2q9p1, T2q9p2, T2q9p3, T2q9p4, T2q9p5 e T2q9p6) o que eles acreditam ser um fruto.

Como já dissemos anteriormente, esse confronto tem por objetivo verificar se após um ano no CBio/USP, se os sujeitos da aprendizagem tiveram alguma alteração nos conceitos biológicos analisados por nós.

O terceiro Questionário (Q3) ${ }^{11}$ (tab. 3), aplicado no final da disciplina Taxonomia de Fanerógamas/BIB-0123 (TF/0123), no $2^{\circ}$ semestre/2007, mais especificamente, no último dia de aula da referida disciplina, preocupou-se em verificar os seguintes aspectos:

a) se ocorreram mudanças no discurso dos alunos ingressantes (CBio/USP/2006) após as duas principais disciplinas que abordam os conceitos de flor e de fruto (Q3q12, Q3q13, Q3q15 e Q3q16);

b) se os alunos conseguem perceber a relação entre o estudo das disciplinas anteriores, como, por exemplo, MAPV/0121 com a disciplina TF/0123 (Q3q2 e Q3q9);

c) como os alunos lidam com a sua formação profissional (Q3q3, Q3q4, Q3q5, Q3q6, Q3q7, Q3q8 e Q3q10); e,

d) quais modalidades didáticas foram utilizadas na Disciplina TF/0123 (Q3q11), bem como, quais os instrumentos de avaliação mais frequentes para verificar o objeto de conhecimento da referida disciplina (Q3q14).

Tabela 3 - Itens e eixos investigativos relacionados ao terceiro questionário (Q3)

\begin{tabular}{|c|c|}
\hline Item & Assunto Abordado pela Questão \\
\hline Q3q1 & Segundo ano no Curso de Ciências Biológicas \\
\hline Q3q2 & Disciplinas que já abordaram os conceitos de flor e de fruto \\
\hline Q3q3 & $\mathrm{N}^{\mathrm{o}}$ de Créditos que cursa atualmente \\
\hline Q3q4 & Motivação \\
\hline
\end{tabular}

\section{Continua}

\footnotetext{
${ }^{11}$ Vide Anexo E.
} 
Conclusão

Tabela 3 - Itens e eixos temáticos relacionados ao terceiro questionário (Q3) aplicado em TF/0123

\begin{tabular}{ll}
\hline Item & \multicolumn{1}{c}{ Assunto Abordado pela Questão } \\
\hline Q3q5 & Leituras extras sobre os assuntos abordados \\
Q3q6 & Uso da Internet para aprofundar os assuntos abordados \\
Q3q7 & Uso da Biblioteca para aprofundar os assuntos abordados \\
Q3q8 & Estágio em que teve contato e fez uso dos conceitos de flor e fruto \\
Q3q9 & Correlação da disciplina TF/0123 com disciplinas anteriores \\
Q3q10 & Por que estuda? \\
Q3q11 & Frequência de modalidades didáticas diversificadas \\
Q3q12 & Aplicação do conceito de flor (reconhecer) \\
Q3q13 & Conceito de flor (discurso) \\
Q3q14 & Instrumentos de avaliação utilizados ao longo da Disciplina TF/0123 \\
Q3q15 & Aplicação do conceito de fruto (reconhecer) \\
Q3q16 & Conceito de fruto (discurso) \\
\hline
\end{tabular}

O terceiro teste $(\mathrm{T} 3)^{12}$, que acompanhou o terceiro questionário, foi aplicado para que possamos confrontar os conceitos expressos pelos sujeitos da aprendizagem no questionário (Q3q13 e Q3q16) com a sua aplicação (em tese), quando solicitamos na primeira questão (T3q17), que os sujeitos identifiquem nas pranchas (T3q17p1, T3q17p2, T3q17p3, T3q17p4, T3q17p5 e T3q17p6) o que eles conhecem como sendo uma flor; e, na segunda questão (T3q18), que os sujeitos identifiquem nas pranchas (T3q18p1, T3q18p2, T3q18p3, T3q18p4, T3q18p5 e T3q18p6) o que eles conhecem como sendo um fruto, fechando o ciclo de confrontações.

Podemos resumir essa apresentação inicial, dizendo que os questionários e as pranchas pretenderam verificar o que os ingressantes no curso de Ciências Biológicas concebiam como “verdades imutáveis" (LEVINAS, 1998) sobre os "objetos de estudo" - os conceitos de flor e de fruto - além de verificar a aplicação desses conceitos na identificação de estruturas florais

\footnotetext{
${ }^{12}$ Vide Anexo F.
} 
e frutíferas (exigência do próprio programa ao término da disciplina MAPV $/ 0121^{13}$ e crucial para o desenvolvimento da disciplina $\mathrm{TF} / 0123$ ).

\subsection{A aplicação dos questionários e dos testes e suas análises.}

A aplicação dos questionários iniciou-se no primeiro semestre de 2006, na Disciplina FFA/0410109, nos dois períodos em que a mesma é oferecida, Integral e Noturno. Naquele primeiro momento, como ainda não tínhamos condições de escolher com qual grupo iríamos continuar a nossa pesquisa, preferimos aplicar o questionário $(\mathrm{Q} 1)$ e o teste $(\mathrm{T} 1)^{14}$ nas duas turmas. Posteriormente, optamos pela turma de ingressantes do CBio/USP/2006, período Integral, composta por cinquenta e um (51) alunos - "sujeitos da aprendizagem", segundo Levinas (1998).

Optamos pelos graduandos do período integral, pelos seguintes motivos:

a) Disponibilidade em acompanhá-los no ano seguinte (2007), ao longo da Disciplina MAPV/0121 e na Disciplina TF/0123.

b) Os graduandos do período integral, após um ano de curso, ingressam imediatamente nas referidas disciplinas, ao contrário do período noturno que, somente após 18 ou 24 meses (conforme o programa e grade curricular disponível na época) ingressam nas mesmas disciplinas, o que tornava o tempo disponível para a pesquisa inviável.

c) Disponibilidade do pesquisador em conciliar os créditos obrigatórios do programa de mestrado com as atividades profissionais (professor) e também com a pesquisa em si.

Passado um ano sem contato com os ingressantes do CBio/USP/2006, voltamos a encontrá-los durante as aulas da disciplina MAPV/0121, como dito anteriormente, no

\footnotetext{
${ }^{13}$ Vide Anexo G e H (Apresentação e Cronograma da Disciplina)

${ }^{14}$ Vide Anexos A e $B$, respectivamente.
} 
primeiro dia de aula da referida disciplina. O questionário $(\mathrm{Q} 2)$ e o teste $(\mathrm{T} 2)^{15}$ foram aplicados a sessenta e seis (66) graduandos, mas para a análise dos dados foram utilizados apenas as informações de cinquenta e um (51) entrevistados, os que ingressaram no CBio/USP em 2006.

Conforme o cronograma da disciplina (Anexo $\mathrm{H}$ ), as aulas sobre os conceitos morfológicos de flor e de fruto deveriam ocorrer, respectivamente, nos dias 23/05/2007 e 06/06/2007, "por questões metodológicas e didáticas"16. Contudo, uma greve dos funcionários da USP, seguida pelos professores e pelos estudantes, inclusive da referida disciplina, forçou os responsáveis pela disciplina a optarem pela reposição das aulas aos sábados, após o término da greve, agrupando os graduandos dos períodos Integral e Noturno em um único horário, dadas as circunstâncias da época, em comum acordo de ambas as partes (pesquisadores-professores doutores e graduandos). Neste caso, segundo o cronograma inicial, o conceito de flor seria dado em um dia e o de fruto em outro dia, na semana seguinte, respeitando as disposições das aulas (manhã os aspectos morfológicos e, à tarde, os aspectos anatômicos). Mas, durante a reposição, o que pudemos observar é que os conceitos foram trabalhados em um único dia, sendo abordado o conceito de flor pela manhã (nos seus aspectos morfológicos e anatômicos) e o conceito de fruto à tarde (nos seus aspectos morfológicos e anatômicos, também). Por causa da greve e da reestruturação do calendário, não nos foi possível aplicar o questionário e o teste aplicados no início da disciplina (Anexos C e D), como havíamos planejado inicialmente.

Como havíamos acompanhado a disciplina MAPV/0121, como Aluno Especial, alguns anos antes, mais especificamente, em 2004, sabíamos que os conceitos de flor e fruto apareciam na fala dos "sujeitos do conhecimento" (pesquisadores-professores doutores) ao

\footnotetext{
${ }^{15}$ Vide Anexos C e D, respectivamente.

${ }^{16}$ Informação oral pronunciada no 1 o encontro da disciplina por um dos Prof. Dr. responsáveis pela disciplina (em 03/03/2007).
} 
longo da disciplina, em momentos pontuais; como as aulas ocorriam ao longo do dia, sendo dividido o curso em duas partes: período Matutino - Morfologia de Plantas Vasculares -, e, período Vespertino - Anatomia de Plantas Vasculares -, optamos por acompanhá-los apenas no período Matutino ${ }^{17}$. Durante o acompanhamento das aulas, fizemos apenas anotações pessoais, pois não nos foi autorizado o uso de equipamentos eletrônicos para captura de som e de imagem. Mesmo assim, pudemos perceber os recursos didáticos mais utilizados ao longo das aulas e também as formas de avaliação presentes na disciplina.

Finalizamos o levantamento dos dados, com a aplicação de um questionário (Q3) e um teste $(\mathrm{T} 3)^{18}$ no final da disciplina TF/0123, no $2^{\circ}$ semestre/2007, mais especificamente, no último dia de aula, com sessenta (60) graduandos, apenas; mas, para a análise dos dados, foram utilizadas apenas as informações de cinquenta e um (51) entrevistados - graduandos regularmente matriculados em 2006 - os ingressantes do CBio/USP/2006.

Ao longo do $2^{\circ}$ semestre/2007, não nos foi possível acompanhar as aulas presenciais por incompatibilidade de horários entre a jornada de trabalho e a disciplina no período Integral. Como já havíamos cursado a mesma disciplina com os mesmos professores doutores em 2004, e, após confrontar o material didático de 2004 com o material didático de 2007, pudemos constatar que a disciplina TF/0123 não sofreu alterações na sua estrutura didática e metodológica. Também fizemos a verificação destes itens por meio das questões Q3q11e Q3q14.

Em relação às questões abertas (Q1q10, Q1q13, Q2q5, Q2q7, Q3q4, Q3q5, Q3q6, Q3q7, Q3q10, Q3q13 e Q3q16) que aparecem nos três questionários (Q1, Q2 e Q3), para a sua análise utilizamos a metodologia "análise de conteúdo" apresentada por Laurence Bardin $(2008 .)^{19}$, que a define como sendo:

\footnotetext{
${ }^{17}$ Nosso foco de estudo é pautado na área da Morfologia de Plantas Vasculares, apenas.

${ }^{18}$ Vide Anexos E e F, respectivamente.

${ }^{19}$ BARDIN, Laurence. Análise de Conteúdo. 3. ed. São Paulo: Ed. Edições 70 Brasil, 2008. 288 p.
} 
Um conjunto de técnicas de análise das comunicações visando obter, por procedimentos sistemáticos e objetivos de descrição do conteúdo das mensagens, indicadores (quantitativos ou não) que permitam a inferência de conhecimentos relativos às condições de produção / recepção (variáveis inferidas) destas mensagens. (BARDIN, 2008, p. 44)

Bardin (2008, p. 23) comenta que, dentro do contexto histórico em que surgiu a análise de conteúdo, pode-se afirmar que existiram duas iniciativas que a "desbloquearam".

São elas:

Por um lado, a exigência de objetividade torna-se menos rígida, ou melhor, alguns investigadores interrogam-se acerca da regra legada pelos anos anteriores, que confundia objetividade e cientificidade com a minúcia da análise de frequências. Por outro, aceita-se mais favoravelmente a combinação da compreensão clínica, com a contribuição da estatística. Mas, para além do mais, a análise de conteúdo já não é considerada exclusivamente com um alcance descritivo [...], pelo contrário, torna-se consciência de que a sua função ou o seu objetivo é a inferência. Que esta inferência se realize tendo por base indicadores de frequência, ou, cada vez mais assiduamente, com a ajuda de indicadores combinados [...], toma-se consciência de que, a partir dos resultados da análise, se pode regressar às causas, ou até descer aos efeitos das características das comunicações. (BARDIN, 2008, p. 23)

Bardin (ibid., p. 41), comparando um analista com um arqueólogo, afirma que o "analista" trabalha com "vestígios", ou seja, documentos que podem ser de dois tipos: a) "naturais", produzidos espontaneamente na realidade; b) “criados", em decorrência da necessidade de estudos. Assim, o analista passa a assumir uma "postura crítica" a partir do tratamento das mensagens que "manipula" para "inferir (deduzir de maneira lógica) ${ }^{20}$ conhecimentos sobre o emissor da mensagem ou sobre o seu meio, por exemplo". O autor, ainda elenca três fases da análise de conteúdo:

$1^{\text {a }}$ etapa: a descrição - a enumeração das características do texto, resumidas após tratamento;

${ }^{20}$ Inferência: operação lógica, pela qual se admite uma proposição em virtude da sua ligação com outras proposições já aceitas como verdades.

Inferir: extrair uma consequência (Petit Robert, Dictionnarie de la langue Française, S. N. L., 1972 apud BARDIN, 2008, p. 41) 
$2^{\mathbf{a}}$ etapa: a inferência - é o que permite a passagem, explicita e controlada, da primeira etapa para a última - a interpretação;

$\mathbf{3}^{\mathbf{a}}$ etapa: a interpretação - a significação concedida as características levantadas na primeira etapa.

Finalmente, Bardin (2008, p. 45, 47) comenta que há dois campos de atuação: a linguística e as técnicas documentais. No primeiro caso, apesar de aparentemente se assemelhar com a análise de conteúdo, a linguística trabalha com a "língua", ou seja, "o aspecto coletivo e virtual da linguagem", enquanto que o da análise de conteúdo trabalha a "fala", isto é, o "aspecto individual" e "ativo" (em ação) da linguagem. Já no segundo caso, o foco principal passa a ser "uma operação ou um conjunto de operações visando representar o conteúdo de um documento sob uma forma diferente do original, a fim de facilitar, num estado ulterior, a sua consulta e referenciação”. Mas, ainda assim, Bardin (ibid., p. 48) aponta diferenças entre a análise documental e a análise de conteúdos. São elas:

- A documentação trabalha com documentos; a análise de conteúdos com mensagens (comunicação);

- A análise documental faz-se principalmente, por classificação - indexação; a análise categorial temática é, entre outras, uma das técnicas da análise de conteúdo.

_ O objetivo da análise documental é a representação condensada da informação, para consulta e armazenamento; o da análise de conteúdo é a manipulação de mensagens (conteúdo e expressão desse conteúdo) para evidenciar os indicadores que permitam inferir sobre outra realidade que não o da mensagem. (BARDIN, 2008, p. 48)

Ao longo da análise dos conceitos dos Ingressantes do CBio/USP/2006, percebemos que se fazia mister verificar o porquê das divergências apresentadas pelos graduandos em conceituar flor. Para tanto, fizemos a análise de alguns livros didáticos de Biologia voltados para o ensino médio. Nesta análise, reportamo-nos diretamente aos conceitos de flor e de fruto, verificando como estavam abordados e exemplificados. Ao final, confrontamos as "falas" dos ingressantes com os conceitos que aparecem nos livros didáticos (Capítulo 4). O 
mesmo se deu com a análise de conteúdos das respostas dos entrevistados dos cursos de MAPV/0121 e TF/0123, onde buscamos na literatura voltada para o ensino superior recomendada pelos responsáveis das já citadas disciplinas e também das apostilas disponibilizadas na seção de cópias - os conceitos propagados de flor e de fruto divulgados pelos "sujeitos do conhecimento". Como comentamos no capítulo 1, nesta análise, reportamonos diretamente aos conceitos de flor e de fruto, verificando como estavam conceituados e exemplificados. Ao final do capítulo 4, confrontamos novamente os discursos dos "sujeitos da aprendizagem" com os conceitos dos "sujeitos do conhecimento", verificando se após as disciplinas houveram alterações no discurso dos "sujeitos da aprendizagem", ou seja, se o mesmo foi (re)formulado e (re)adequado à nova "realidade", ou melhor, ao novo contexto em que se encontravam.

Para as questões Q3q4, Q3q5, Q3q6, Q3q7 e Q3q10, nos utilizamos dos estudos de Caldeiras (2000), onde o mesmo procura distinguir quatro abordagens de aprendizagem, baseado principalmente nas obras de Marton $(1983,1984)$ e Entwistle e seus colaboradores $(1984 ; 1985 ; 1986 ; 1987 ; 1988)$, que reproduzimos a seguir:

Quadro 6 - Caracterização das abordagens ao estudo

\begin{tabular}{|l|l|}
\hline Abordagem & \multicolumn{1}{|c|}{ Caracterização } \\
\hline Superficial & $\begin{array}{l}\text { Intenção do sujeito cumprir os requisitos da tarefa, memorizando a } \\
\text { informação e dando realce aos elementos isolados, sem os integrar; } \\
\text { não existe uma reflexão cuidadosa dos objetivos e das estratégias de } \\
\text { aprendizagem. }\end{array}$ \\
\hline Estratégica & $\begin{array}{l}\text { Intenção do estudante obter as melhores classificações, } \\
\text { organizando, para isso, o seu tempo de modo a rentabilizar o } \\
\text { esforço, e acima de tudo, o estudante procura, por um lado, possuir } \\
\text { enunciados de exames anteriores, para prever as questões, e, por } \\
\text { outro, estar atento aos processos e critérios de avaliação (Entwistle, } \\
1986) .\end{array}$ \\
\hline
\end{tabular}


Conclusão

Quadro 6 - Caracterização das abordagens ao estudo

\begin{tabular}{|l|l|}
\hline Abordagem & \multicolumn{1}{|c|}{ Caracterização } \\
\hline Profunda & $\begin{array}{l}\text { Intenção de compreender, atenta e criticamente, o conteúdo do } \\
\text { material acadêmico e pelo relacionamento de novas ideias com } \\
\text { conhecimentos adquiridos previamente ou com a experiência do } \\
\text { quotidiano. }\end{array}$ \\
\hline Desorganizada ou não-acadêmica & $\begin{array}{l}\text { Deficiente estratégia de estudo, associada a motivações de ordem } \\
\text { social (Entwistle, Kozék \& Pollitt, 1987), e por atitudes negativas } \\
\text { em relação ao estudo, possuindo o estudante métodos de estudo } \\
\text { desorganizado. }\end{array}$ \\
\hline
\end{tabular}

Fonte: Caldeiras (2000, p. 323)

\subsubsection{A análise dos dados}

As respostas dos ingressantes foram inseridas em um banco de dados, utilizando-se, para isso, o programa Access ${ }^{\circledR} 97^{21}$, para agrupamento dos dados. Os gráficos e tabelas gerados a partir destes dados e apresentados nos resultados foram criados através dos programas Excel® 2007 e Word® 2007.

Para a categorização dos dados, nos utilizamos das orientações metodológicas de Bardin (2008, p. 121). O mesmo nos diz que a análise de conteúdo se organiza em torno de três polos cronológicos:

1) a pré-análise;

2) a exploração do material;

3) o tratamento dos resultados, a inferência e a interpretação.

Bardin $(i d$.$) considera a pré-análise como sendo "a fase da organização propriamente$ dita". Possui três dimensões: a escolha dos documentos a serem submetidos à análise, a

\footnotetext{
${ }^{21}$ Posteriormente, os dados foram migrados e analisados utilizando-se o programa Access ${ }^{\circledR} 2003$.
} 
formulação das hipóteses e dos objetivos e a elaboração de indicadores que fundamentem a interpretação final.

A escolha dos documentos a serem submetidos à análise se dá através do processo que ele chama de "leitura flutuante", por analogia com a atitude do psicanalista. A mesma consiste em estabelecer contato com os documentos a analisar e em conhecer o texto deixando-se invadir por impressões e orientações. Após a delimitação do universo de documentos sobre os quais se pode efetuar a análise, passa-se então, para a segunda fase, a escolha dos documentos que irão constituir o "corpus". A sua constituição implica, muitas vezes, delimitações, seleções e regras. Eis as principais regras:

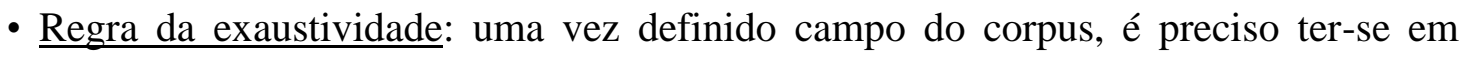
conta todos os elementos desse corpus.

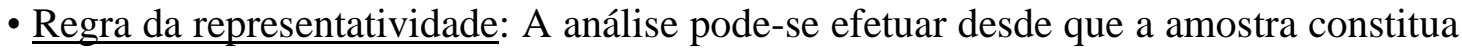
ou represente uma parte representativa do universo inicial. Neste caso, os resultados obtidos para a amostra serão generalizados ao todo.

- Regra da homogeneidade: os documentos devem ser homogêneos, quer dizer, devem obedecer a critérios precisos de escolha e não apresentar demasiada singularidade fora destes critérios de escolha.

- Regra de pertinência: os documentos retidos devem ser adequados, enquanto fonte de informação, de modo a corresponderem ao objetivo que suscita a análise.

E finalmente, após a aplicação das regras que melhor se adéquam ao seu material, parte-se para a formulação das hipóteses e dos objetivos. Mas, nem sempre as hipóteses são estabelecidas a partir da pré-análise, destaca o autor. Por outro lado, não é obrigatório ter-se como guia um corpus de hipóteses, para se proceder à análise. Algumas 
análises efetuam-se "às cegas" e sem ideias pré-concebidas. Uma das várias técnicas é considerada a priori, para fazer "falar" o material, utilizando-se dela sistematicamente. (Bardin, 2008, p. 124)

Para Bardin (ibid., p. 125) há vários procedimentos, mas ele destaca dois: os "fechados", caracterizados essencialmente por "técnicas taxonômicas", ou seja, por classificação de elementos de textos em função de critérios internos ou externos com a função de experimentação de hipóteses; e os "de exploração", aos quais podem corresponder técnicas ditas "temáticas", (e nomeadamente automáticas), as quais permitem, a partir dos próprios textos, "aprender as ligações entre as diferentes variáveis, funcionando segundo o processo dedutivo que facilitam a construção de novas hipóteses”.

Logo em seguida, parte-se para a refinação dos índices e a elaboração de indicadores que a análise fará "falar" sobre o texto em si, delimitando o trabalho preparatório a escolha destes - em função das hipóteses, caso elas estejam determinadas - e sua organização sistematizada em indicadores. (BARDIN, ibid., p. 126)

A pré-análise encerra-se após a "construção de indicadores precisos e seguros". Desde a pré-análise devem ser determinadas operações de "recorte do texto" em unidades comparáveis de "categorização" para análise temática e de modalidade de codificação, para o registro dos dados.

A “preparação do material”, segunda etapa da análise de conteúdo, tem como premissa a "edição" do material. Esta "preparação formal" ou "edição" dos textos geralmente começa com o alinhamento dos enunciados intactos, proposição por proposição, até a transformação linguística dos sintagmas, para classificação e padronização por equivalência, seguida da "exploração do material", tida como uma "fase mecânica", "longa" e "fastidiosa", consiste 
essencialmente em operações de "codificação", “decomposição" ou "enumeração", em função de regras previamente estabelecidas [...] (BARDIN, 2008, p. 127)

No nosso caso, como as respostas abertas dos entrevistados estavam inseridas no banco de dados, foi mais fácil proceder com a sua organização, pois o próprio programa utilizado nos permite editar um modelo de relatório, onde podemos incluir os campos que consideramos importantes, como, por exemplo, dados do cadastro do entrevistado, as respostas propriamente ditas, entre outras informações. E, como não poderia deixar de ser, realizamos a exploração do material, buscando verificar as falas dos entrevistados, levantando os conceitos preconizados pela Botânica sobre flor e fruto.

Finalmente, a terceira fase da análise de conteúdo, compreende o tratamento dos resultados obtidos e a interpretação dos mesmos, processo esse que consiste no tratamento dos dados brutos de maneira a serem significativos (falantes) e válidos.

Neste processo, Bardin (2008, p. 127) nos diz que as operações estatísticas simples, como por exemplo, as percentagens, ou mais complexas como a análise fatorial, nos permitem estabelecer quadros de resultados, diagramas, figuras e modelos, os quais condensam e põem em relevo as informações fornecidas pela análise, quando afirma que

Tratar o material é codificá-lo. A codificação corresponde a uma transformação efetuada segundo regras precisas - dos dados brutos em texto, transformação esta que, por recorte, agregação e enumeração, permite atingir uma representação do conteúdo ou da sua expressão suscetível de esclarecer o analista acerca das características do texto, que possam vir a servir de índices. (BARDIN, 2008, p. 128)

A organização da codificação compreende três escolhas (no caso de uma análise quantitativa e categorial): 
a) o recorte: escolha das unidades (temas, palavras ou frases), onde a escolha de registro e de contexto deve responder de maneira pertinente (pertinência estabelecida em relação às características do material e face aos objetivos da análise);

b) A enumeração: escolha das regras de contagem;

c) A classificação e a agregação: escolha das categorias.

No caso do recorte, pode-se dizer que parte-se para a delimitação de signos; signos estes que, Segundo J. Teixeira Coelho Netto (2003, p. 20) é "tudo aquilo que representa outra coisa, ou melhor, na descrição de Charles S. Pierce, é algo que está no lugar de outra coisa”. Para Saussure (apud Netto, 2003, p. 20), signo pode ser analisado segundo duas partes que o compõem: "o conceito" e a "imagem acústica". Posteriormente, estes termos foram substituídos, respectivamente, por "significado" e "significante".

J. Teixeira Coelho Netto (2003, p. 23) diferencia significado de significante, dizendo que o significante representa "a parte material do signo", ou seja, o som, os ícones. Já o significado passa a ser considerado o "conceito vinculado por essa parte material", "seu conteúdo", "a imagem mental fornecida pelo significante".

Neste sentido, Bardin (2008, p. 130), comenta que

Todas as palavras do texto podem ser levadas em consideração, ou pode-se reter unicamente as palavras-chave ou as palavras-tema [...]; pode igualmente fazer-se a distinção entre palavras plenas e palavras vazias; pode ainda efetuar- se a análise de uma categoria de palavras: substantivos, adjetivos, verbos, advérbios (...) a fim de se estabelecer quocientes. (BARDIN, 2008, p. 130)

Em relação às regras de enumeração, as mesmas são consideradas como "o modo de contagem". Para tanto, Bardin (2008, p. 134-135) comenta que é possível utilizar diversos tipos de enumerações, entre eles: 
A presença (ou ausência): [A] presença [de certos elementos] pode ser significativa, funcionando neste caso como um indicador. No entanto, a ausência de elementos (relativamente a uma certa provisão) pode, em alguns casos, veicular um sentido. [...] Com efeito, para certos tipos de mensagens, como para certos objetivos de análise, a ausência pode constitui uma variável importante.

A frequência: a frequência é a medida mais geralmente usada. Corresponde ao postulado (válido em certos casos e noutros não) seguinte: a importância de uma unidade de registro aumenta com a frequência de aparição.

A frequência ponderada: se supusermos que a aparição de determinado elemento tem mais importância do que um outro, podemos recorrer a uma intensa de ponderação. [...] A ponderação pode corresponder a uma decisão tomada a priori, mas pode também traduzir as modalidades de expressão ou a intensidade de um elemento.

A Intensidade - A medida de intensidade com que cada elemento aparece é indispensável na análise dos valores (ideológicos, tendências) e das atitudes. (BARDIN, 2008, p. 134-135)

Por sua vez, a ponderação da frequência traduz um caráter quantitativo (intensidade) ou qualitativo: a direção. A direção pode ser favorável, desfavorável ou neutra (eventualmente, ambivalente), num caso de estudo de favoritismo, desfavoretismo.

A ordem de aparição das unidades de registro (por exemplo, numa entrevista ou em um relato) pode ser o índice pertinente. Ou então a frequência e o encadeamento das unidades de registro podem combinar-se nas medidas.

O uso da associação como indicador assenta geralmente no postulado de que elementos associados em uma manifestação da linguagem estão (ou estarão) igualmente associados no espírito do locutor (ou do destinatário).

Portanto, para Bardin (2008, p. 139)

[...] qualquer escolha de uma regra (ou de várias regras) de enumeração assenta numa hipótese de correspondência entre a presença, a frequência, a intensidade, distribuição, a associação da manifestação da linguagem e a presença, a frequência, a intensidade, a distribuição, a associação de variáveis inferidas, não linguísticas. É conveniente procurar a correspondência mais pertinente. (BARDIN, 2008, p. 139) 
No nosso caso, consideramos o mais pertinente a presença (ou a ausência) dos principais conceitos vinculados ao signo flor, como, por exemplo, os termos: "angiosperma", "gineceu”, “androceu”, “sépala”, “pétala”, “corola", "estame”, “estilete”, entre outros já comentados anteriormente. O mesmo se deu com a categorização dos conceitos de fruto, como, por exemplo: "ovário desenvolvido", "semente", "partenocárpico", entre outros, por acreditarmos que presença ou ausência nos permita questionar a relação que o sujeito da aprendizagem tem com o seu objeto de estudo. Portanto, acreditamos que a nossa abordagem neste estudo se caracteriza como uma pesquisa qualitativa, conforme defende Bardin (2008).

Como o autor ressalva,

[A Análise qualitativa] é valida, sobretudo, na elaboração das deduções específicas sobre um acontecimento ou uma variável de inferência precisa, e não em inferências gerais. Pode funcionar sobre corpus reduzidos e estabelecer categorias mais descriminantes, visto não estar ligada, enquanto análise quantitativa, a categorias que tendem a dar lugar a frequências suficientemente elevadas para que os cálculos se tornem possíveis. Levanta problemas ao nível das pertinências dos índices retidos, visto que seleciona estes índices sem tratar exaustivamente todo o conteúdo [...]. (BARDIN, 2008, p.141)

Por último, Bardin (2008, p. 141) considera que a "análise qualitativa não rejeita toda e qualquer forma de quantificação". 


\title{
CAPÍTULO 4. RESULTADOS E DISCUSSÃO
}

\begin{abstract}
Nossas teorias sociológicas, nossa filosofia política, nossa economia e nossas doutrinas educacionais derivam-se de uma tradição ininterrupta de grandes pensadores e exemplos práticos desde a época de Platão... até o final do século passado. Toda essa tradição está dominada pela premissa de que cada geração vive substancialmente em meio às condições que governaram as vidas de seus progenitores e que serão transmitidas para moldar com igual força as vidas de seus filhos. Estamos vivendo no primeiro período da história humana para a qual esta suposição é falsa. Alfred North Whitehead (1965) em The Adventure of Ideas

Se a aula é dada apenas de acordo com as regras fixas e por processos já comprovados, comportamo-nos como os operários em frente a uma máquina cujo funcionamento não compreendem. Hans Aebli (1973) em Práticas de Ensino.
\end{abstract}

Neste capítulo caracterizaremos a nossa amostra e também faremos uma análise dos resultados dos questionários e dos testes de confrontação aplicados ao longo dos dois anos em que acompanhamos os Ingressantes do CBio/USP/2006 na sua formação profissional.

\subsection{Ingressantes do curso de Ciências Biológicas da USP - 2006}

Conforme dito anteriormente, nossa amostra é composta por cinquenta e um (51) graduandos que ingressaram no curso de Ciências Biológicas da Universidade de São Paulo em 2006 (CBio/USP/2006), no período Integral.

Antes de ingressarem na USP, estes estudantes passaram pelo processo seletivo do Vestibular realizado pela Fuvest (Fundação Universitária para o Vestibular). Conforme as 
Estatísticas apresentadas pela própria Fuvest $(2006)^{22}$, foram inscritos para o curso 3.156 candidatos, dos quais 183 estiveram ausentes na prova $(5.8 \%)$ ( $1^{\mathrm{a}}$ fase). Entre os que compareceram, apenas 357 candidatos $(11.31 \%)$ foram convocados para a segunda fase. Finalmente, entre os que realizaram a $2^{\mathrm{a}}$ fase, foram matriculados, efetivamente, 120 candidatos, à Carreira 400- Ciências Biológicas, sendo: sessenta (60) candidatos, no Curso 20-Licenciatura e Bacharelado - Integral, e, sessenta (60) candidatos no Curso 22Licenciatura e Bacharelado - Noturno.

Verificando as questões da Fuvest/2006 ${ }^{23}$, especificamente, em relação ao conteúdo de Biologia $\left(1^{\text {a }}\right.$ fase - questões objetivas ${ }^{24} ;$ e, $2^{\text {a }}$ fase - questões dissertativas $\left.{ }^{25}\right)$, encontramos, no caso de flor, apenas o conceito implícito, vinculado ao conceito de angiosperma. Segue abaixo a questão 93 (Fig. 5), onde podemos verificar o conceito de angiosperma (implícito o conceito de flor) exigido pela questão:

\section{As angiospermas se distinguem de todas as outras plantas pelo fato de apresentarem \\ a) alternância de geração haplóide e diplóide. \\ b) estômatos nas folhas. \\ c) flores. \\ d) sementes. \\ e) vasos condutores de seiva.}

Figura 5. Questão 93, extraída da Fuvest/2006, 1ª fase, Biologia.

Como apresentado no capítulo 2, a estrutura reprodutiva flor encerra em si mesma oito (8) autapomorfias do grupo das angiopermas, possibilitando-nos vincular o conceito de flor

\footnotetext{
22 FUVEST. In: < http://www.fuvest.br/scr/hist1f.asp?anofuv=2006\&tipo=1\&carreira=400>. Acessado em: 18 jan. 2010.

${ }^{23}$ Anexos I e J.

${ }^{24}$ FUVEST. In: <http://www.fuvest.br/vest2006/provas/p1f2006v.pdf>. Acessado em: 18 jan. 2010.

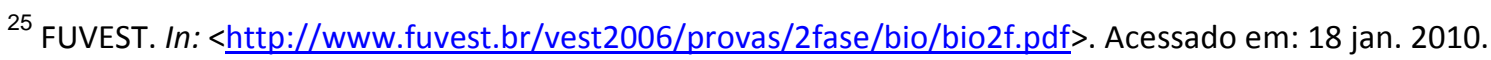


como "exclusivo" das angiospermas (JUDD, W. et al., 2009; MENEZES et al. 2004). Ou seja, a resposta correta para esta questão, é a opção C.

Segundo a Fuvest (2006) ${ }^{26}$, esta questão apresentou um Índice de Discriminação (ID) de $23.1 \%$, referente aos candidatos que realizaram a sua matrícula no referido curso. Em outras palavras,

[...] o índice de discriminação representa o quanto esta questão serviu para discriminar os "bons candidatos" (aqueles que foram "bem" na prova) dos "maus candidatos" (aqueles que foram "mal" na prova). Note que quento [sic] mais alto for o valor de ID (quanto mais perto de 100\%) melhor é a questão para fins de discriminação. (FUVEST, 2006)

Em relação à questão sobre fruto, a encontramos na prova dissertativa de Biologia, questão $\mathrm{n}^{\circ} 5$, como mostrada abaixo (Fig. 6):

\section{Q.05}

A polinização é um evento essencial para a produção de frutos nas plantas. Em algumas espécies, no entanto, pode haver formação de frutos na ausência de polinização, se as flores forem pulverizadas com certos hormônios vegetais.

a) Que parte da flor é estimulada pelos hormônios a se desenvolver em fruto?

b) Qual é a diferença entre um fruto gerado pela aplicação de hormônios, sem que haja polinização, e um fruto resultante da polinização?

Figura 6. Questão 5, extraída da Fuvest/2006, $2^{\mathrm{a}}$ fase, Biologia.

Nesta questão, apesar de o foco recair sobre o desenvolvimento do fruto provocado pelo uso de hormônios, em especial a auxina, o candidato à vaga pretendida deveria saber o conceito de fruto, que “em angiospermas corresponde ao ovário (ou grupo de ovários) desenvolvido, que contém as sementes, junto com quaisquer outras partes adjacentes que

26 FUVEST. In: <http://www.fuvest.br/scr/id1fq.asp?fase=3\&anofuv=2006\&carr=400\&mat=4\&tipo=2\&quest=5\&totquest=12>. Acessado em: 18 jan. 2010. 
possam estar fundidas a eles na maturidade" (RAVEN, EVERT, EICHHORN, 2001, p. 860), bem como o conceito de fruto partenocárpico ${ }^{27}$.

Segundo a Fuvest $(2006)^{28}$, esta questão apresentou um ID de $20.23 \%$ para os inscritos na segunda fase, em Ciências Biológicas (cód. 400). Mas, quando analisado segundo aqueles que foram matriculados, este valor cai para $9.68 \%$.

Chamamos a atenção a estas duas questões, pelo fato de ambas, de uma forma indireta e/ou direta, solicitarem aos candidatos (em geral), e aos Ingressantes no CBio/USP/2006, os conceitos de flor e de fruto que abordamos no capítulo 2 e que retomaremos a partir de agora, na apresentação dos dados e nas discussões a seguir.

\subsubsection{Os resultados do primeiro questionário $(\mathrm{Q} 1)$}

Ao longo deste subtópico, apresentaremos os gráficos produzidos a partir dos dados gerados pela análise dos questionários e, em seguida, as tabelas com as "falas" dos sujeitos da aprendizagem organizadas em agrupamentos pela afinidade dos discursos.

Q1q1: Em que tipo de escola você cursou o Ensino Médio? Se estudou em escolas alternadas, marques as duas opções e diga quanto tempo em cada:

\footnotetext{
${ }^{27}$ Fruto partenocárpico - Fruto sem sementes (In: TAIZ, L., ZEIGER, E., et al., 2009, p. 575).

${ }^{28}$ FUVEST. In: <http://www.fuvest.br/scripts/id2fq.asp?quest=5\&prova=4\&anofuv=2006\&carreira=400\&cond=C >. Acessado em: 18 jan. 2010.
} 
No período Integral, tivemos como respostas apenas em Escola Pública ou Escola Particular (gráfico 1). Questão semelhante, mas com mais opções de tabelamento foi realizada pela Fuvest $(2006)^{29}$; os resultados são similares, guardadas as devidas proporções. ${ }^{30}$

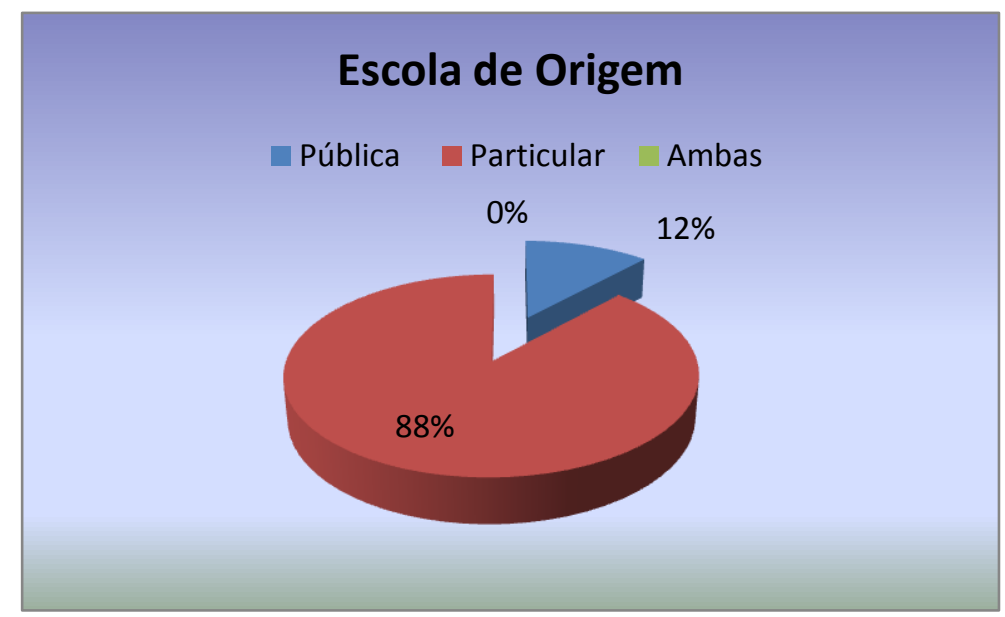

Gráfico 1. Porcentagem dos Ingressantes do CBio/USP/2006 que frequentaram escola pública, particular e/ou ambas. Amostra composta por 51 entrevistados.

\section{Q1q3:O curso de Ciências Biológicas na USP é o seu primeiro curso superior?}

Esta questão tinha um desdobramento, através do qual os entrevistados que já haviam feito um curso superior anteriormente deveriam esclarecer qual era o curso e se o concluíram. Obtivemos apenas duas (2) respostas entre aqueles que afirmaram "não", sendo que um entrevistado cursou anteriormente Gastronomia e o outro iniciou o curso de Biotecnologia, mas ambos não concluíram a primeira graduação.

\footnotetext{
${ }^{29}$ Vide dados socioeconômicos em:
} <http://www.fuvest.br/scr/qasen.asp?anofuv=2006\&fase=3\&carr=0000000400\&quest=07\&tipo=3\&grupo=1>. Acessado em 18 jan. 2010.

${ }^{30}$ O mesmo comentário é válido para as questões Q1q3, Q1q8. 


\section{Primeiro curso superior}

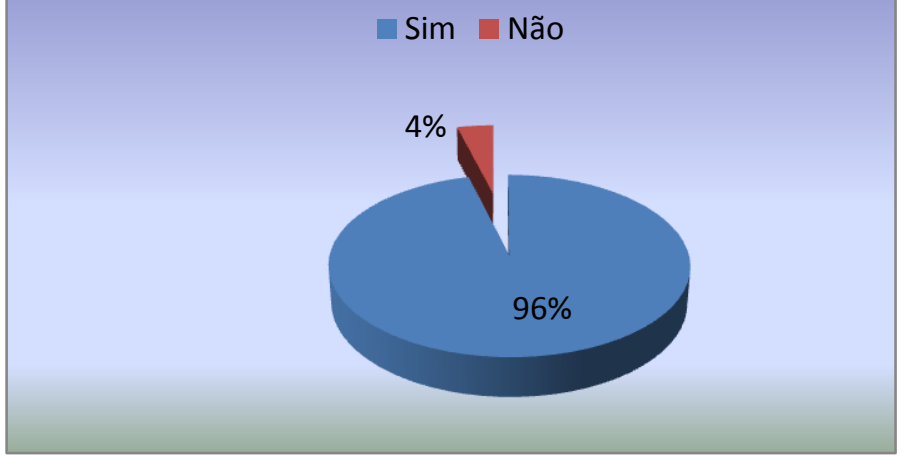

Gráfico 2. Porcentagem dos Ingressantes do CBio/USP/2006 que frequentam um curso superior pela primeira vez, ou não. Amostra composta por 51 entrevistados.

Q1q4: Durante o Ensino Médio, o professor e/ou a Instituição onde você estudou, $\underline{\text { adotou algum tipo de material pedagógico de Biologia? }}$

Essa questão se desdobra na seguinte (Q1q5), quando verificamos que tipos de material didático foram mais utilizados pelos professores durante o ensino médio.

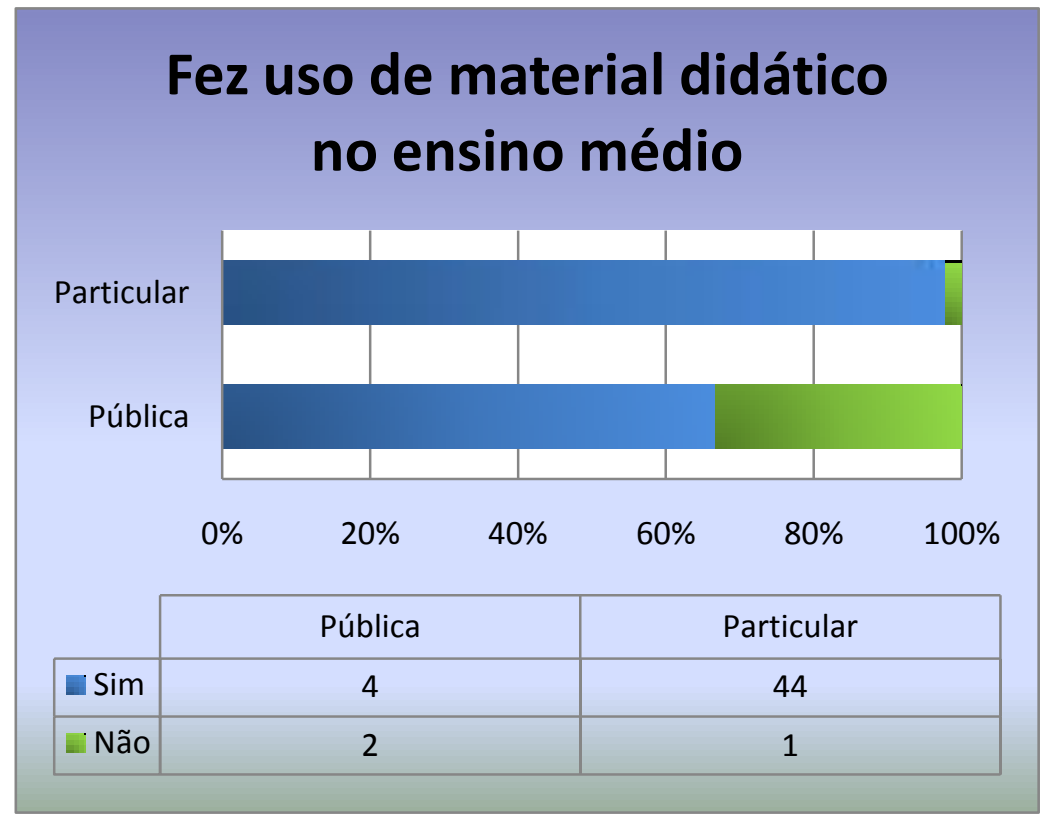

Gráfico 3. Relação dos entrevistados que fizeram uso de material didático ao longo do ensino médio. Os dados presentes na tabela interna referem-se ao número de respostas dadas para cada item. 
Percebe-se no gráfico 3, uma diferença significativa entre aqueles que fizeram uso de materiais didáticos, como livros, apostilas, etc., e os outros alunos que não fizeram uso, ou seja, $97.78 \%$ dos alunos oriundos das escolas particulares e $66.66 \%$ dos alunos oriundos das escolas públicas, neste caso.

Q1q5: Qual(is) o(s) tipo(s) de material(is) pedagógico(s) adotado(s)? Anote na frente o nome da(s) obra(s) e/ou autor(es) que você se lembrar (pode assinalar mais de uma opção).

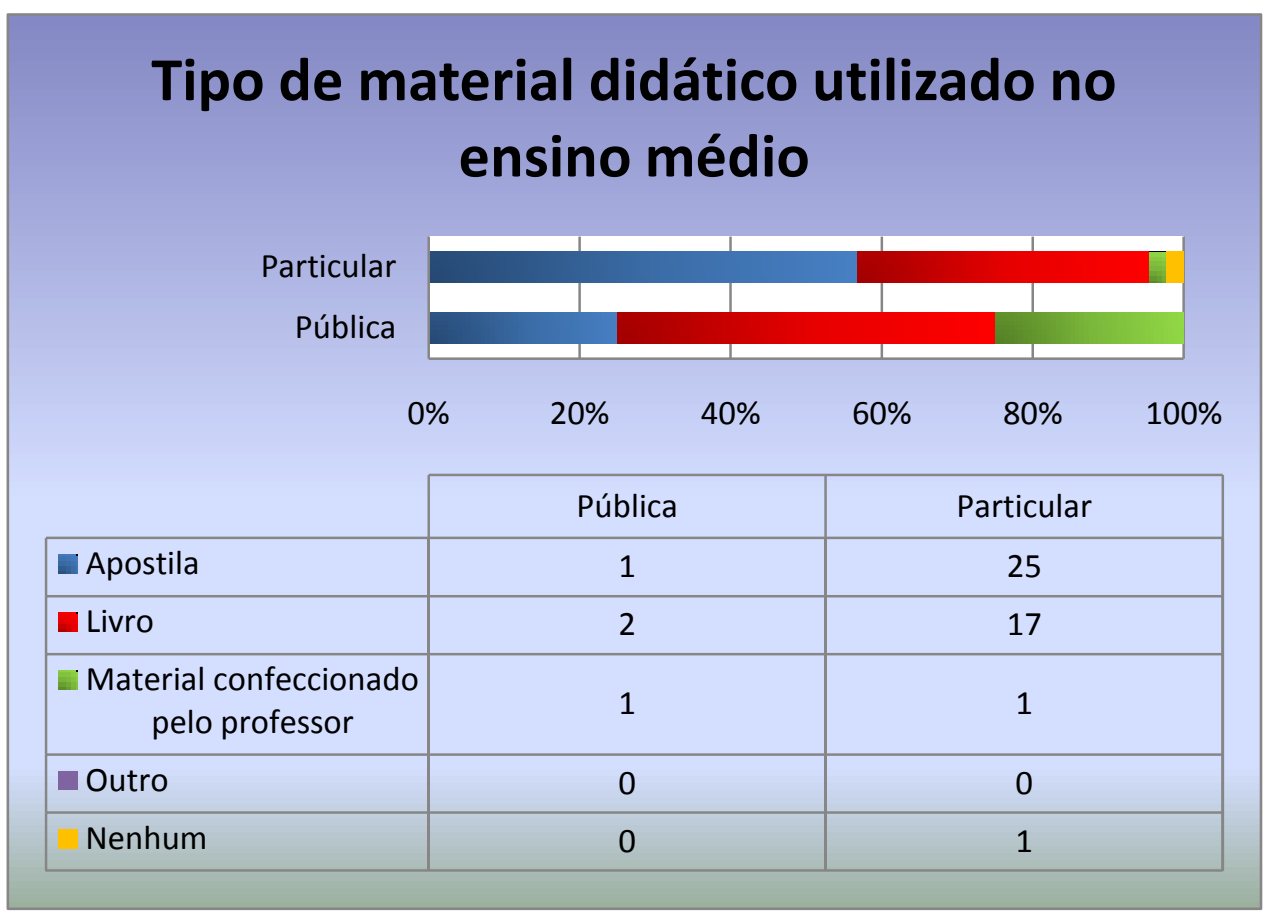

Gráfico 4. Relação dos materiais didáticos utilizados durante o ensino médio, por escola. Amostra composta por 48 alunos. Os dados presentes na tabela interna referem-se ao número de respostas dadas para cada item.

Percebe-se mais claramente, nesta questão, que o material mais utilizado pelas escolas particulares está vinculado às apostilas. Nesse sentido, as obras que aparecem com maior frequência são aquelas confeccionadas pelo Grupo Anglo (seis respostas), Grupo Objetivo 
(cinco respostas) e Companhia Escola (três respostas); seis outros grupos apareceram, mas com apenas uma resposta cada. E, finalmente, cinco alunos não citaram a origem da apostila usada durante o ensino médio. Em relação à escola pública, o aluno não citou a obra.

Dentre os livros didáticos, os que se destacam foram três coleções. O primeiro deles, "Fundamentos da Biologia Moderna - Volume Único", cujos autores são: José Mariano Amabis; Gilberto Rodrigues Martho, da Ed. Moderna, com seis citações por alunos oriundos da escola particular; uma indicação por aluno da escola pública. A segunda coleção mais citada foi a da autora Sonia Lopes, mas sem identificação da obra, com três indicações cada, empatando em número de indicações com a obra "Biologia - Volume Único", dos autores Armênio Uzunian; Ernesto Birner, da Ed. Harbra - Universitários, ambas citadas pelos alunos oriundos de escolas particulares. Finalmente, tivemos uma citação da coleção "Biologia", dos autores Sezar Sasson e Cesar da Silva Jr, pela Ed. Saraiva. Apenas quatro entrevistados não citaram as obras.

Estes dados são importantes na medida em que nos permitem verificar a origem dos conceitos científicos que aparecem no discurso dos ingressantes do CBio/USP/2006, e, até mesmo comparar algumas delas com os conceitos morfológicos de flor e de fruto que aparecem nestas obras didáticas.

Q1q6: Durante o Ensino Médio, você teve aulas de Botânica?

A base dos nossos estudos está pautada no ensino-aprendizagem de botânica, em especial, nos conceitos de flor e fruto. Esperávamos que os entrevistados confirmassem a 
nossa pré-concepção de que todos, se não a maioria, tiveram contato com os principais tópicos de Botânica, no ensino médio.

\section{Ingressantes que tiveram aulas de Botânica}

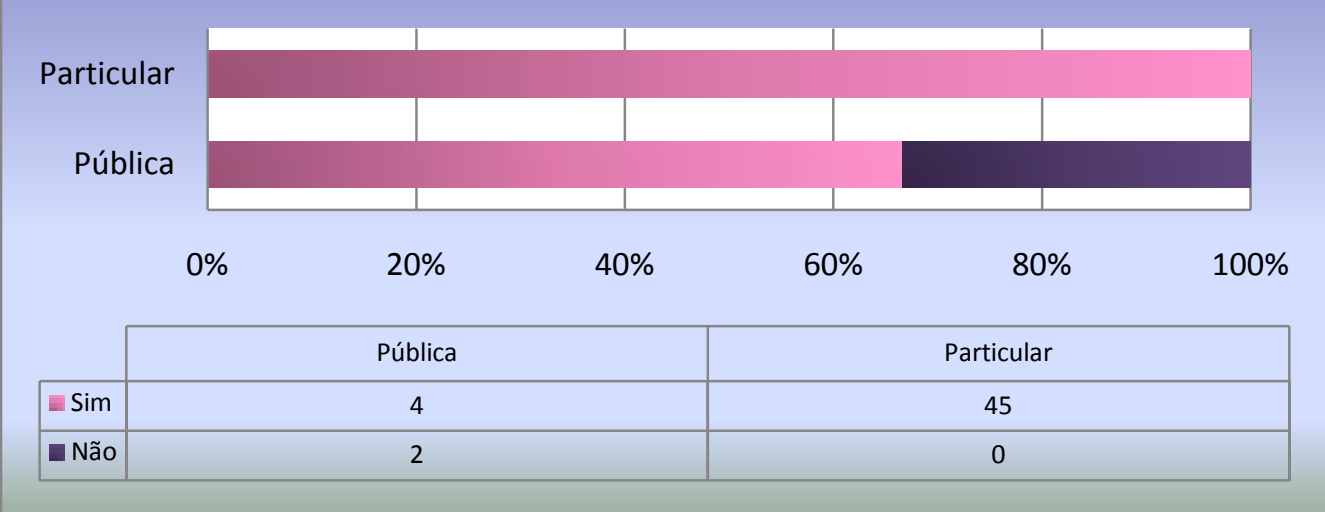

Gráfico 5. Porcentagem dos ingressantes do CBio/USP/ 2006 que tiveram aulas de botânica, durante o ensino médio. Consideramos os seis (6) entrevistados da escola pública e os quarenta e cinco (45) entrevistados oriundos da escola particular - total da amostra: 51 entrevistados. Os dados presentes na tabela interna referemse ao número de respostas dadas para cada item.

Como dissemos anteriormente, os conceitos de flor e de fruto são abordados pela área da Botânica ${ }^{31}$. Pode-se perceber que a maioria dos ingressantes do CBio/USP/2006 tiveram aulas de botânica no ensino médio, com exceção de dois alunos apenas, oriundos da rede pública. Pensando nesta questão, propusemos a questão seguinte (Q1q7) para verificarmos se, dentre todos os que tiveram as aulas de botânica, os mesmos foram contemplados com os conceitos biológicos supracitados.

\footnotetext{
${ }^{31}$ Botânica - s. f. Campo da biologia que tem por objeto o reino vegetal e que se divide em grandes áreas de estudo, como a fisiologia, a morfologia e a sistemática, subdivididas em vários ramos especializados [A botânica moderna se inicia com Lineu (Karl von Linné, 1707-1778), botânico sueco, e compreende duas áreas fundamentais: a botânica pura e a botânica aplicada.] (In: Dicionário Houaiss da Língua Portuguesa. < http://houaiss.uol.com.br/busca.jhtm?verbete=Bot\%E2nica\&x=10\&y=6\&stype=k>. Acessado em: 18 out. 2010.
} 
Q1q7: Durante as aulas de Botânica, foi discutido o conceito de Flor?

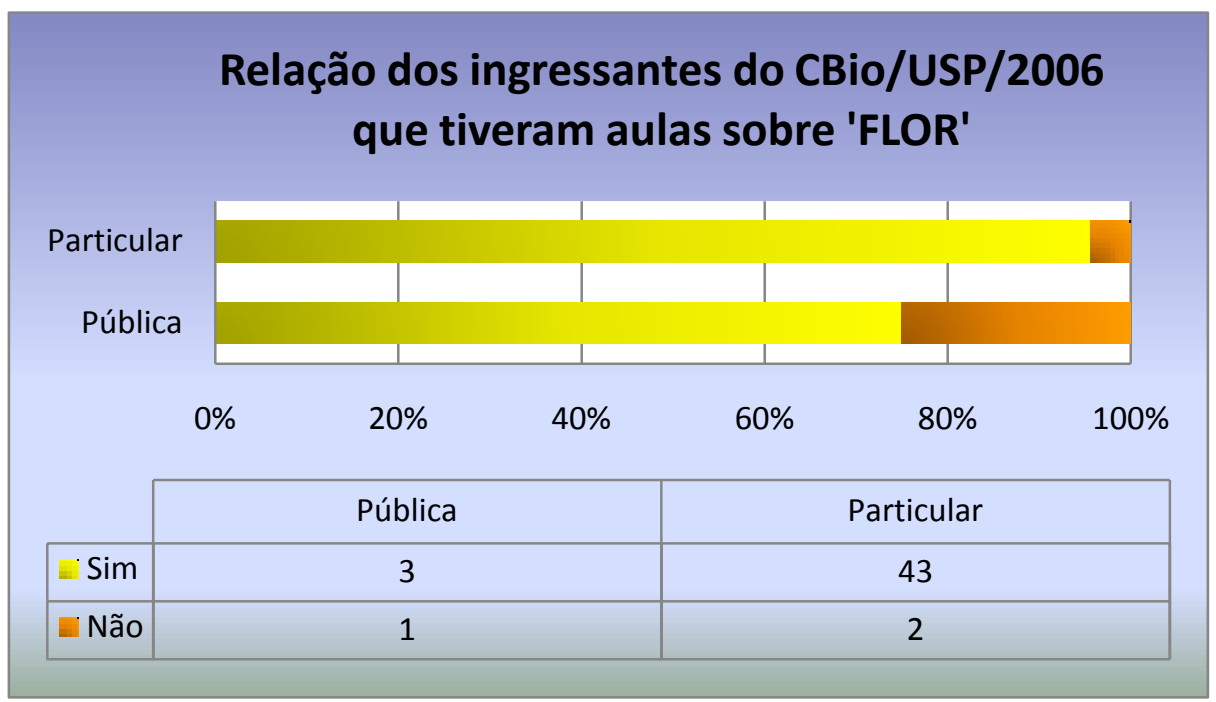

Gráfico 6. Porcentagem dos Ingressantes do CBio/USP/2006 que tiveram aulas sobre flor, no ensino médio. Foram considerados apenas os entrevistados que tiveram aulas de botânica - 49 estudantes. Os dados presentes na tabela interna referem-se ao número de respostas dadas para cada item.

Para a tabulação dos dados desta questão, criamos uma condição no banco de dados para que, ao gerar o relatório, considerasse apenas os casos que tiveram aulas de Botânica no ensino médio. Com essa ferramenta, oferecida pelo próprio programa Access ${ }^{\circledR} 2003$, procuramos evitar um viés na tabulação ${ }^{32}$.

A próxima questão (Q1q8), também abordada pela Fuvest $(2006)^{33}$, permite-nos perceber que uma porcentagem considerável dos ingressantes do CBio/USP/2006, recorreu ao cursos preparatórios para o vestibular (popularmente denominados de "Cursinhos").

Q1q8: Durante ou após ter concluído o Ensino Médio, você fez curso preparatório para o Vestibular (Cursinho)?

\footnotetext{
$32 \mathrm{O}$ mesmo procedimento foi adotado para a o item Q1q11.

${ }^{33}$ Vide notas 29 e 30.
} 


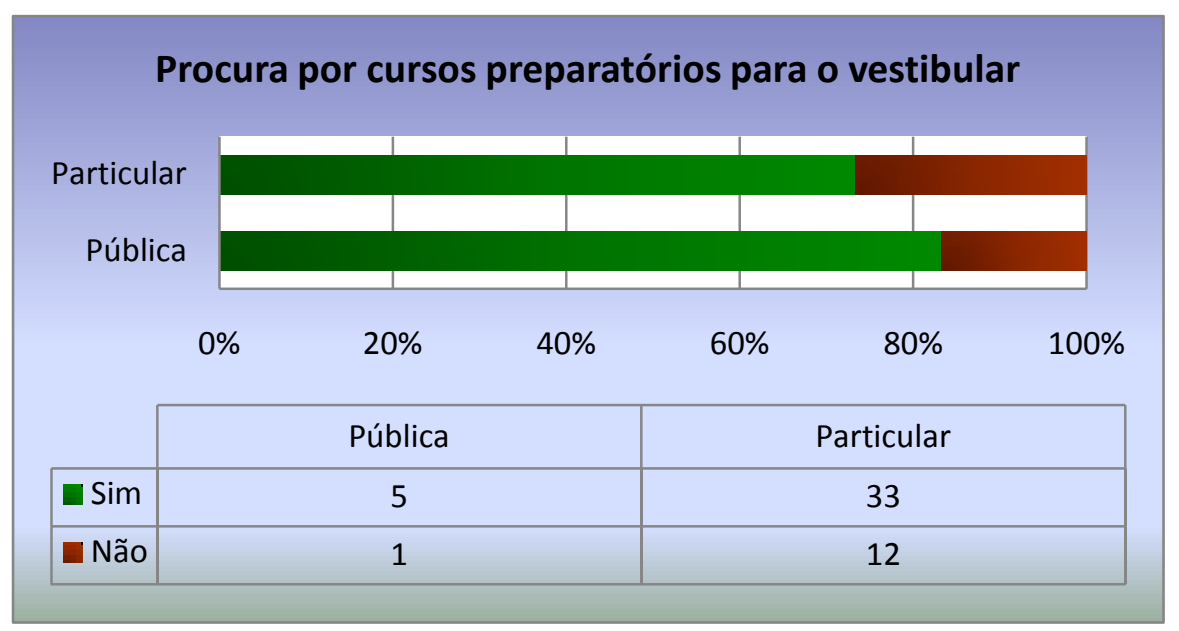

Gráfico 7. Porcentagem dos Ingressantes do CBio/USP/2006 que fizeram "cursinho" antes de ingressar no $\mathrm{CBio} / \mathrm{USP} / 2006$. Amostra composta por 51 estudantes. Os dados presentes na tabela interna referem-se ao número de respostas dadas para cada item.

Comparando os dados, podemos perceber que a diferença pela procura por "cursinhos" é de $10 \%$, em relação aos ingressantes oriundos da rede pública para com os oriundos das escolas particulares.

Q1q9: Você acredita ser capaz de reconhecer visualmente uma Flor?

Os ingressantes tiveram, ao longo de sua vida estudantil e antes de ingressarem no CBio/USP/2006, uma longa jornada de aprendizagem, iniciando-se no ensino fundamental, perpassando, no mínimo, oito anos ${ }^{34}$, além dos três anos, no mínimo, do ensino médio, totalizando, pelo menos, 11 anos de estudos. Neste período, todos tiveram diversas oportunidades de rever o seu conceito de flor e de adaptá-lo às suas necessidades cotidianas

\footnotetext{
34 Atualmente, o tempo de duração do ensino fundamental é de nove anos, conforme a Lei no 11.274 , sancionada pelo Presidente da República no dia 06/02/2006.
} 
bem como às próprias exigências de avaliações e de processos seletivos, como, por exemplo, o vestibular da USP, a Fuvest.

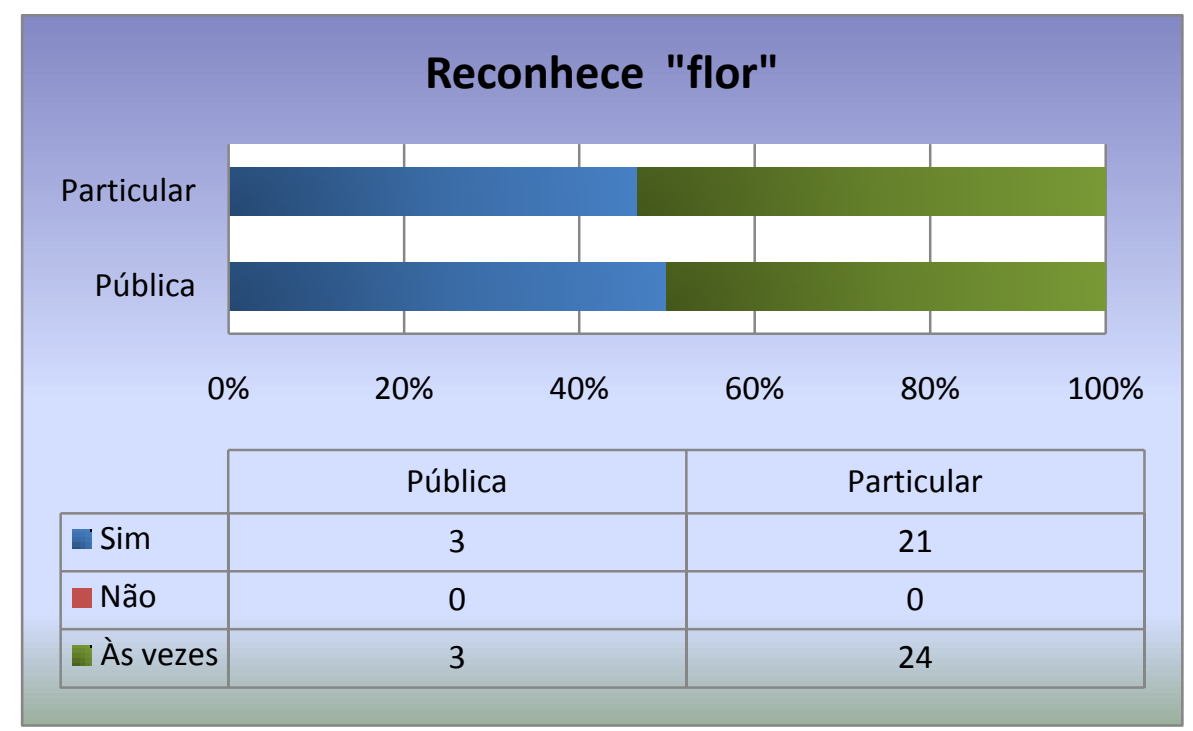

Gráfico 8. Relação dos ingressantes do CBio/USP/2006 que afirmam reconhecer sempre ou às vezes, uma flor. Amostra composta por 51 estudantes. Os dados presentes na tabela interna referem-se ao número de respostas dadas para cada item.

Podemos perceber que os ingressantes podem ser divididos, segundo suas respostas, praticamente na mesma proporção em ambos os casos. Todos se acham em condições de reconhecer, mesmo que às vezes, uma flor. Na discussão, procuraremos aprofundar essa relação entre os dados do gráfico 8 com os dados referente ao primeiro teste (T1), mais especificamente, aos dados relacionados à questão T1q14, e os conceitos fornecidos pelos ingressantes do CBio/USP/2006 nas questões Q1q10 e Q1q13.

A próxima questão - Q1q10 e a última Q1q13, por exigir uma discussão mais ampla dos dados levantados e, como a metodologia empregada foi a mesma para ambas, decidimos abordá-las em conjunto (vide item 4.1.1.1). 


\section{Q1q11: Durante o seu Ensino Médio, foi explorado o conceito de Fruto?}

Para essa questão, obtivemos a mesma porcentagem apresentada no gráfico 6 . Acreditamos que isso ocorreu porque os conceitos de flor e de fruto são abordados juntos, geralmente, no momento em que os autores propõem o estudo sistemático dos seres vivos, mais especificamente, ao se estudar as gimnospermas e as angiospermas ${ }^{35}$.

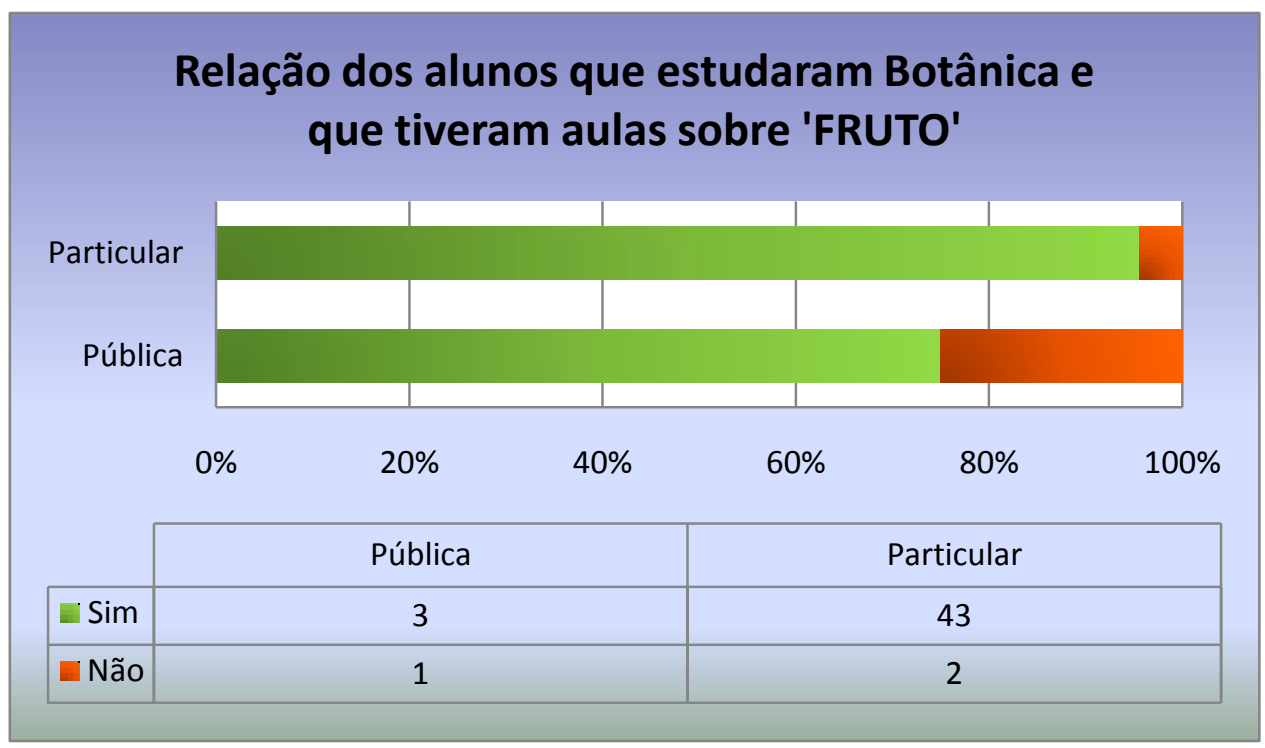

Gráfico 9. Porcentagem dos ingressantes do CBio/USP/2006 que tiveram aulas sobre fruto, no ensino médio. Foram considerados apenas os entrevistados que tiveram aulas de botânica - 49 estudantes. Os dados presentes na tabela interna referem-se ao número de respostas dadas para cada item.

${ }^{35}$ Os conceitos de flor e de fruto são mais empregados no estudo das angiospermas. Mas, por questões didáticas, alguns dos autores de livros didáticos, muitas das vezes, preferem abordar os dois grupos juntos, e, consequentemente, o conceito de flor aparece também no tópico sobre gimnospermas, quando há uma comparação entre os estróbilos (órgãos reprodutores das gimnospermas) e as flores (órgão reprodutor das angiospermas). O conceito de fruto é abordado somente em angiosperma. Como referência, sugerimos ao leitor que veja as obras didáticas voltadas para o ensino de biologia no ensino médio, citadas pelos ingressantes do CBio/USP/2006. 


\section{Q1q12: Você seria capaz de reconhecer visualmente um Fruto?}

Os dados do gráfico 10 nos chamam a atenção pelo fato de sinalizarem que os ingressantes CBio/USP/2006 admitem ter mais dificuldades em reconhecer um fruto do que uma flor (vide gráfico 8). Outro dado interessante é o apresentado sobre a questão cinco (q.5) da Fuvest $/ 2006$, que teve um ID $=9.68 \%$, como citado anteriormente. Ou seja, os alunos demonstram um domínio conceitual de fruto, mas não conseguem fazer a sua transposição didática para a prática.

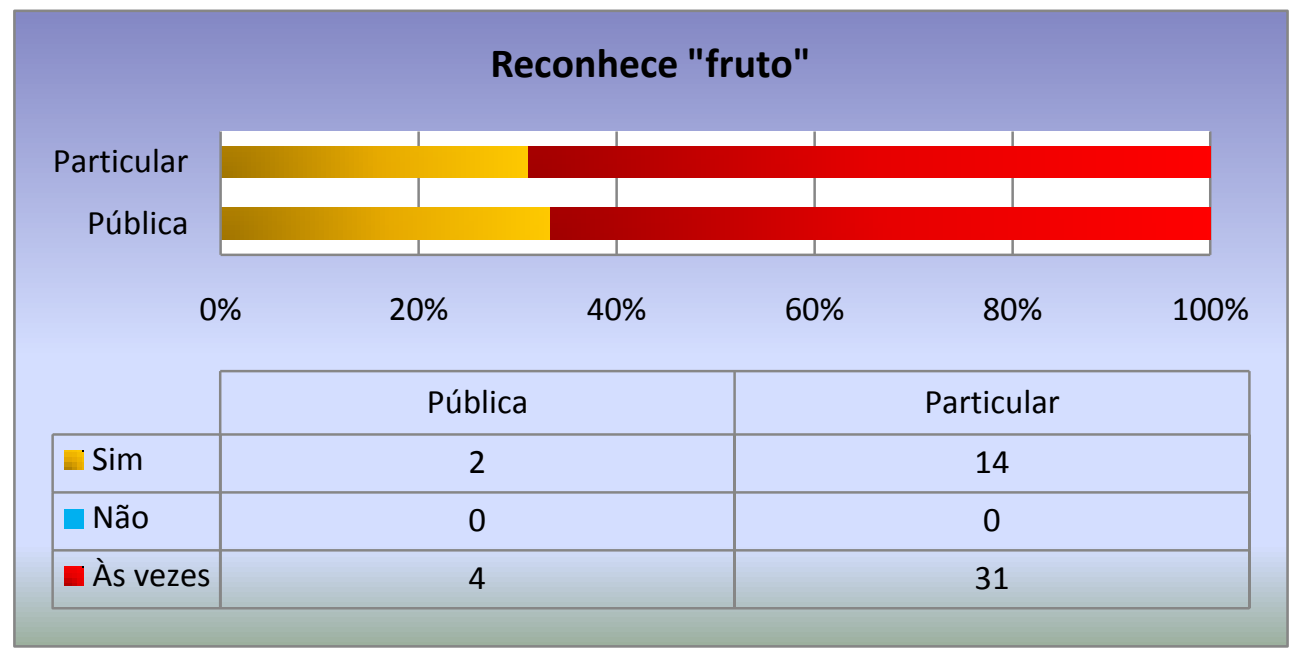

Gráfico 10. Relação dos ingressantes do CBio/USP/2006 que afirmam reconhecer sempre ou às vezes, um fruto. Amostra composta por 51 estudantes. Os dados presentes na tabela interna referem-se ao número de respostas dadas para cada item.

Podemos perceber que os ingressantes se dividem nas respostas, sendo que, neste caso, diferentemente do item Q1q9, mais alunos apresentam dificuldades em reconhecer um fruto, conforme o gráfico 10. Mesmo assim, todos se acham em condições de reconhecer, mesmo que às vezes, um fruto. Na discussão, procuraremos aprofundar essa relação entre os dados do gráfico 10 com os dados referentes ao primeiro teste (T1), mais especificamente, os dados 
relacionados à questão T1q15, e os conceitos fornecidos pelos ingressantes CBio/USP/2006 nas questões Q1q10 e Q1q13 (próximo subtópico).

\subsubsection{Os conceitos de flor e de fruto presentes no discurso dos ingressantes CBio/USP/2006}

O item Q1q10, por ser uma questão aberta, possibilita ao pesquisador, dentre outras coisas, "avaliar processos mentais superiores, como a capacidade para analisar, organizar e sintetizar o conhecimento, aplicá-lo e avaliá-lo; e a habilidade para exprimir opiniões e ideias, usando uma linguagem exata e adequada" (HAYDT, R. C., 2007, p. 117) (negrito nosso). Essa questão exige que o entrevistado "enuncie os atributos essenciais e específicos de um objeto, fato, processo ou fenômeno, indicando as categorias a que estaria associado” (VIANNA, H. M., 1973, p. 87, apud HAYDT, R. C., 2007, p. 116) (negrito nosso).

No nosso caso em específico, o ingressante do CBio/USP/2006, ao ser solicitado que responda a pergunta Q1q10: "Na sua opinião, qual a melhor maneira de se conceituar uma Flor?", busca resgatar um conceito prévio abordado em anos anteriores sobre o assunto em pauta - conceito de flor.

Como descrito no Capítulo 3- Materiais e Métodos, utilizamos como referência para a análise das respostas abertas, a proposta de análise de conteúdo de Bardin (2008). 
Inicialmente, ao realizarmos a leitura "flutuante", percebemos que o material apresenta as condições necessárias para a análise de conteúdo, ou seja, enquadra-se dentro dos objetivos propostos nos possibilitando verificar a evolução e/ou as mudanças dos conceitos morfológicos de flor e de fruto fornecidos pelos Ingressantes do CBio/USP/2006 ao longo do curso de graduação. $\mathrm{O}$ questionário preenche as regras de representatividade, de homogeneidade e de pertinência. Em relação à segunda regra, buscamos comparar as respostas entre si, em um primeiro momento, e no global, em um segundo momento. Após as operações de recorte do texto e de categorização, partimos para a análise temática e de modalidade de codificação para o registro dos dados. Assim sendo, obtivemos os seguintes dados apresentados na tab. 4:

Tabela 4 - Categorização do conceito de flor do ingressantes CBio/USP/2006

\begin{tabular}{|c|c|c|}
\hline Categoria & Item & N. $^{\circ}$ de ocorrências \\
\hline \multirow{4}{*}{ Grupos Taxonômicos } & Plantas (senso amplo) & 27 \\
\hline & Angiospermas & 10 \\
\hline & Gimnospermas & 4 \\
\hline & Fanerógamas & 3 \\
\hline \multirow{15}{*}{$\begin{array}{l}\text { Partes constituintes } \\
\text { de uma flor }\end{array}$} & Androceu & 5 \\
\hline & Gineceu & 5 \\
\hline & Gameta(s) & 5 \\
\hline & Estame & 4 \\
\hline & Pétala & 2 \\
\hline & Pistilo & 2 \\
\hline & Sépala & 2 \\
\hline & Ovário & 2 \\
\hline & Gametófito & 2 \\
\hline & Oosfera & 2 \\
\hline & Estilete & 1 \\
\hline & Antera & 1 \\
\hline & Cálice & 1 \\
\hline & Corola & 1 \\
\hline & Grão de pólen & 1 \\
\hline \multirow{2}{*}{ Características } & Órgão/Aparelho reprodutor & 31 \\
\hline & Órgão feminino & 7 \\
\hline
\end{tabular}

\section{Continua}


Conclusão

Tabela 4 - Categorização do conceito de flor do ingressantes CBio/USP/2006

\begin{tabular}{llc}
\hline Categoria & Item & N. $^{\text {o de ocorrências }}$ \\
\hline & Órgão masculino & 7 \\
Características & Colorida & 2 \\
& Apresenta cheiro/aroma & 1 \\
& Hermafrodita & 1 \\
\hline Função & Monoica & 4 \\
& Atrativa & 3 \\
\hline \multirow{2}{*}{ Fenômenos } & Transforma-se em fruto & 2 \\
& Polinização & 2 \\
\hline Ontogênese & Fecundação & 1 \\
\hline
\end{tabular}

Nota - (1) Foram consideradas 51 respostas para a tabulação dos dados. (2) Às vezes, o mesmo termo aparece mais de uma vez na resposta do entrevistado.

Neste caso, podemos inferir que o conceito de flor aparece atrelado às plantas (senso amplo). Aparecem diversas respostas, como nos casos abaixo:

“órgão sexual de uma planta” (FFA/002/2006) (negrito meu)

“Aparelho reprodutor da planta" (FFA/050/2006) (negrito meu)

“Órgão sexual de uma planta” (FFA/023/2006) (negrito meu)

A ideia de flor como órgão exclusivo das angiospermas aparece em apenas $15.7 \%$ da amostra, ou seja, em apenas oito (8) respostas. Como, por exemplo:

“Órgão Reprodutor das Angiospermas” (FFA/015/2006) (negrito meu) 
“Estrutura reprodutiva das angiospermas" (FFA/009/2006) (negrito meu)

Em outros casos, foi possível perceber também o conceito de flor atrelado às gimnospermas $^{36}$ e as angiospermas ou ao grupo das fanerógamas (7 respostas). Exemplos:

“Aparelho de reprodução de gimnospermas e angiospermas” (FFA/014/2006) (negrito meu)

“Uma flor é o órgão reprodutor de plantas fanerógamas, possuindo muitas vezes cor e cheiro bem atrativos.” (FFA/014/2006) (negrito meu)

Dentre todas as respostas dadas, uma delas, do entrevistado FFA/032/2006, traz uma consideração de suma importância para a nossa discussão, pois, ao se referir ao conceito de flor, automaticamente se remete ao conceito de flor pautado na "fala" do professor, quando se expressou da seguinte maneira:

“Desculpe, não me lembro exatamente as palavras do professor - (tem que possuir estame, pistilo e ovário?!)” (negrito meu)

Neste caso, pode-se perceber claramente a sinalização do Ingressante em querer registrar o "conceito" exatamente como lhe foi transmitido, para que não tenha o receio de estar errado. Neste sentido, comenta Levinas (1998, p. 32) que

[...] é no âmbito da [educação] que se estabelecem fabulosas batalhas, que vão desde a resistência a abandonar determinadas ideias fundamentais, até a incorporação de novos conceitos, a modificação de noções importantes e a internalização de uma enorme quantidade de informações. (LEVINAS, 1998, p. 32)

\footnotetext{
${ }^{36}$ Todas as vezes que o item "gimnosperma" foi citado, o mesmo apareceu associado ao item "angiospermas".
} 
A "batalha", ou o conflito cognitivo apresentado pelo Ingressante passa a ser a escolha do referencial teórico que lhe melhor lhe possibilite conceituar flor dentro do novo contexto em que se encontra inserido - o ensino superior. Esse novo contexto ainda é "desconfortável”, pois os ingressantes se encontram em fase de adaptação. Consequentemente os conflitos mentais e dúvidas são maiores.

Em relação à questão T1q14: “A seguir são apresentadas 6 imagens. Considerando o $\underline{\text { seu conhecimento sobre o conceito de flor, circule em cada uma das imagens a(s) estrutura(s) }}$ que você considera como sendo uma flor. Não marque nada nas imagens em que você não identificar, pelo menos, uma flor", tivemos os seguintes resultados apresentados na tab. 5:

Tabela 5. Respostas dos Ingressantes do CBio/USP/2006, obtidas em relação ao item T1q14, quando solicitados a circundar o que eles consideram como sendo "uma flor".

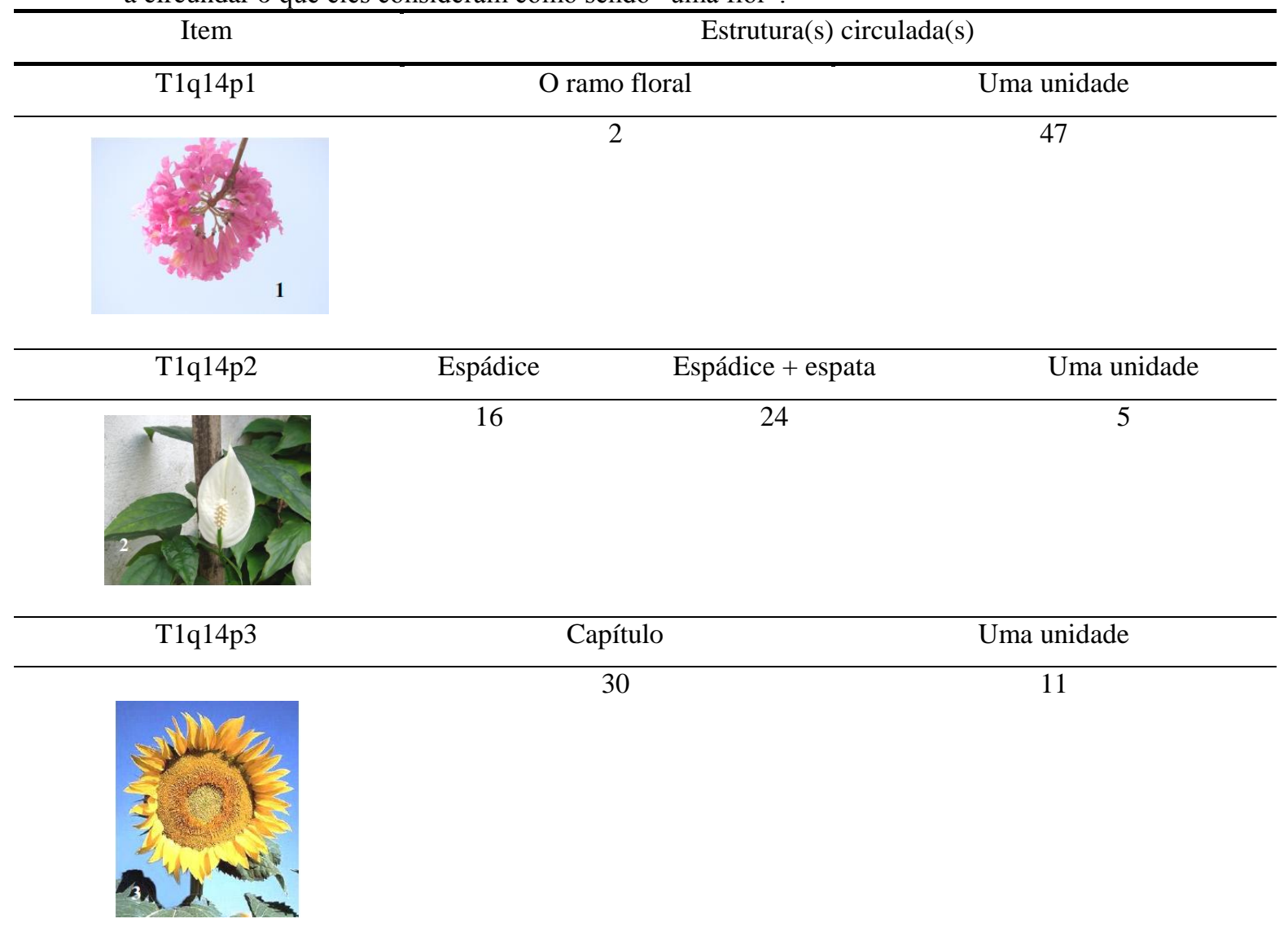




\section{Conclusão}

Tabela 5. Respostas dos Ingressantes do CBio/USP/2006, obtidas em relação ao item T1q14, quando solicitados a circundar o que eles consideram como sendo "uma flor".

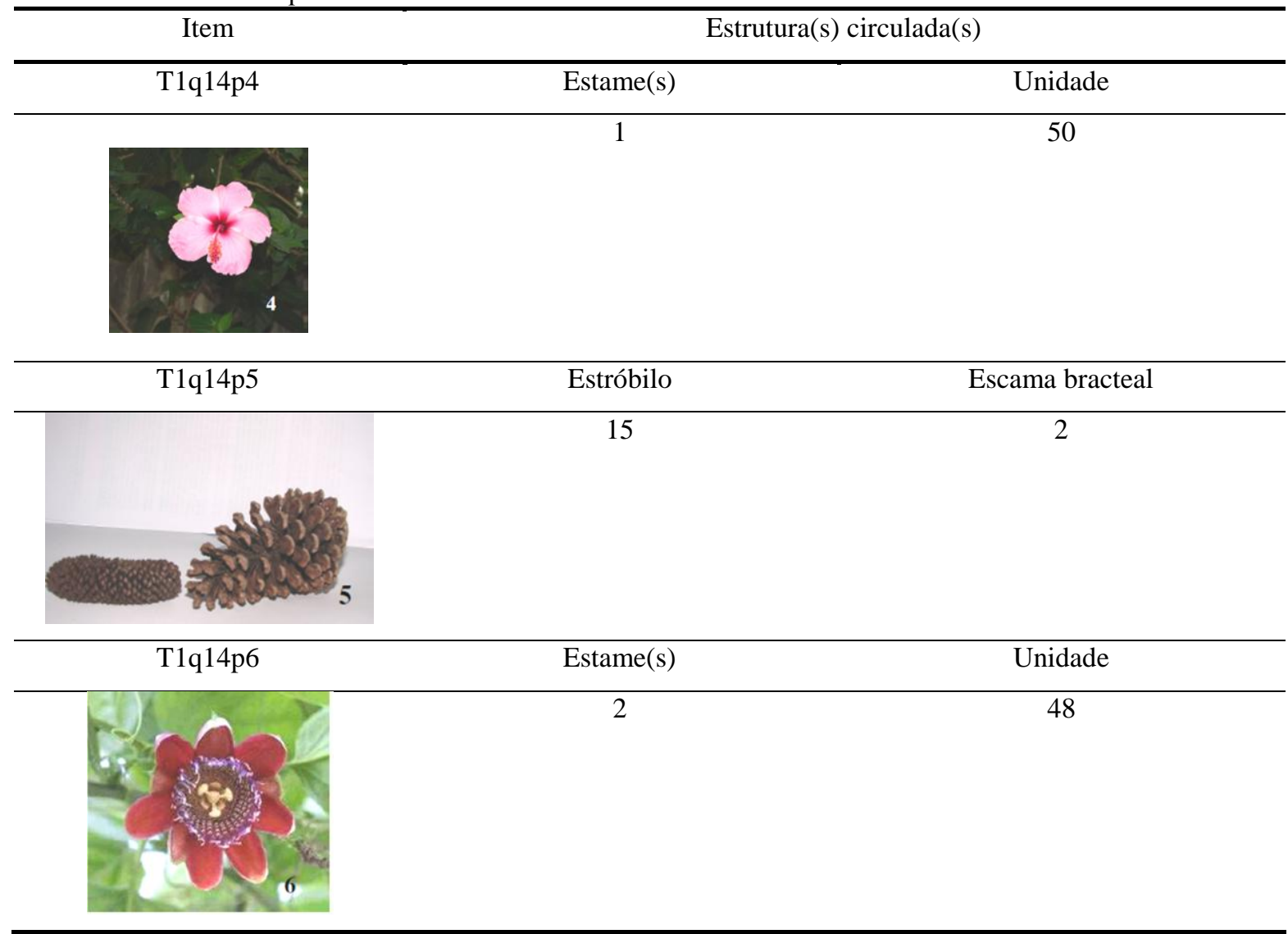

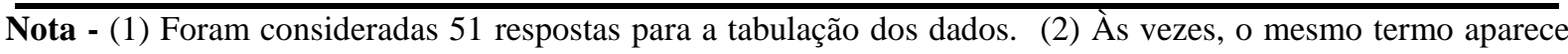
mais de uma vez na resposta do entrevistado.

Alguns entrevistados (sete apenas) fazem observações pontuais em relação ao item

T1q14p5, através das quais podemos perceber claramente que existem controvérsias de alguns autores em considerar ou não os estróbilos das Coníferas como sendo uma flor. Vejamos alguns dos comentários:

“Os estróbilos podem ser considerados como flores, apesar de não pertencerem às Angiospermas". (FFA/006/2006) (negrito meu)

"Os autores não concordam entre si quanto à classificação da "flor" número 5. Eu a considero um estróbilo”. (FFA/009/2006) (negrito meu) 
“5) Há controvérsias, alguns autores a consideram flor, enquanto outros não.” (FFA/ 010/2006) (negrito meu)

"5= Pode ser considerado como flor das criptógamas por alguns autores, ou não?" (FFA/012/2006) (negrito meu)

No caso abaixo (FFA/013/2006), o entrevistado chama a atenção para o conceito de inflorescência ao se manifestar em relação ao item T1q14p5, mas não consegue fazer a sua utilização, pois além de circundar apenas um pedaço de uma escama bracteal também assinala os itens T1q14p2 e T1q14p3 como sendo uma única flor (Fig. 7).

“5 = Inflorescência (conjunto de várias flores)” (FFA/013/2006)

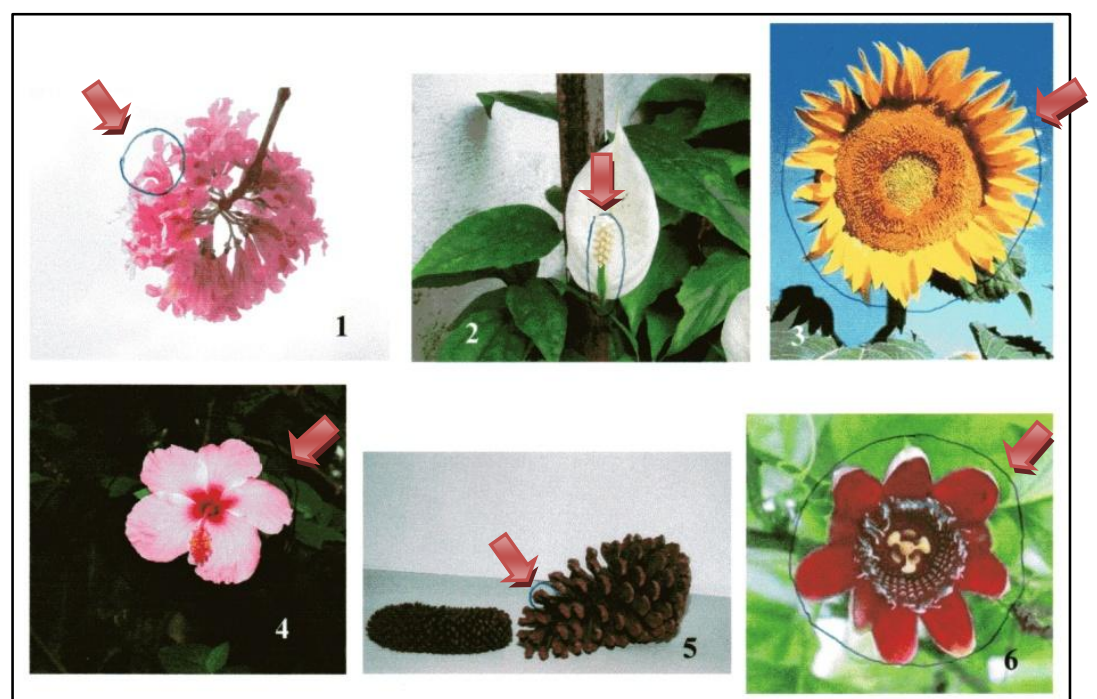

Figura 7. Respostas do entrevistado FFA/13/2006 em relação ao item T1q12. As setas em vermelho indicam as marcações do entrevistado.

Levando-se em consideração as respostas dos entrevistados acima, o que se pode perceber é uma dificuldade em definir qual o referencial teórico ou "pressuposto" a ser 
adotado para afirmarem que o estróbilo de uma gimnosperma pode ou não ser considerado como "uma flor". Levinas (1998, p. 27) comenta que:

\begin{abstract}
Em todos os casos, o papel dos pressupostos é determinante, e os processos para que os indivíduos sejam instruídos a respeito desses pressupostos resultam cruciais na hora de determinar como são e como se ativam os mecanismos que permitem a adoção de novas ideias que, geralmente, se opõem a um pensamento natural ou ao senso comum. (LEVINAS, 1998, p. 27)
\end{abstract}

Pensando nesse apontamento, fizemos um breve levantamento de como o conceito de flor aparece em algumas obras de Biologia voltadas para o ensino médio. Na coleção Biologia dos organismos da Ed. Moderna, (AMABIS, MARTHO, 2004, p.162), encontramos a seguinte descrição sobre flor:

\begin{abstract}
A flor, assim como o estróbilo das gimnospermas, é um ramo especializado em que há folhas férteis com esporângios, os esporofilos. O ramo que contém a flor é denominado pedicelo (do latim, pediculus, pequeno pé). No pedicelo há o receptáculo floral, que é a parte do ramo floral em que se encaixam diversos tipos de folhas especializadas, os elementos florais, algumas delas formadoras de esporângios. Os elementos que produzem esporângios (esporofilos) são os carpelos ou megasporofilos (formam os óvulos) e os estames ou microsporofilos (formam os grãos de pólen). O conjunto de carpelos é denominado gineceu (do grego gyne, mulher, e oikos, casa) e o conjunto de estames é o androceu (do grego andros, homem, e oikos, casa). (...)" (AMABIS, MARTHO, 2004, p.162) (negrito dos autores)
\end{abstract}

Neste caso, na associação do termo flor é estabelecida a ideia de "um ramo especializado", portador de "folhas modificadas", com a função de reprodução.

No Dicionário Etimológico e Circunstanciado de Biologia, Ed. Scipione, (SOARES, 1993, p.175), flor é definida como:

Flor. (Do lat. flos, 'flor'). Conjunto de folhas profundamente modificadas, transformadas em peças florais (sépalas, pétalas, estames e carpelos), que, agrupadamente, formam os verticilos que constituem a flor; órgão exclusivo das plantas Fanerógamas ou Espermáfitas (vegetais superiores) que contém as estruturas especializadas para a reprodução, quais sejam o androceu e o gineceu, envoltos pelos verticilos protetores (cálice e corola). É sustentada pelo pedúnculo, que a 
mantém presa ao caule. Pode mostrar-se isolada ou reunida em inflorescências. Nas Gimnospermas (pinheiros ou coníferas), apresenta-se formada de peças secas, duras e sem beleza, recebendo o nome de estróbilo ou cone. Nas Angiospermas, assume os mais variados feitios, tamanhos e cores, com agradáveis aromas. (...) (SOARES, 1993, p.175) (negrito do autor)

Como é possível observar acima, no Dicionário de Biologia, o termo flor é citado como "conjunto de folhas profundamente modificadas", pertencentes "exclusivamente ao grupo das Fanerógamas", com a diferença de que o nome dado à estrutura presente nas coníferas é de "estróbilo" ou "cone" e, no caso das angiospermas, o nome "flor" é mantido, atribuindo-se a ela características como, por exemplo, "cores variadas" e "aromas agradáveis”. Mas, Raven et al. (2001, p. 511) nos lembra que nem todas as flores presentes nas Angiospermas possuem um aroma agradável. Segundo o autor, a família Asclepiadaceae apresenta flores malcheirosas e frequentemente escuras como, por exemplo, a espécie Stapelia schinzii, geralmente polinizada por moscas que se alimentam de matéria orgânica em decomposição.

$\mathrm{Na}$ coleção Biologia - Ciência da Vida, da Ed. Atual, (MARCONDES, LAMMOGLIA, 1997, p. 315), flor é definida como "o órgão reprodutor das fanerógamas. Evolutivamente, representa um conjunto de folhas modificadas e especializadas".

Encontramos na coleção Biologia Hoje, Ed. Ática, (LINHARES, GEWANDSZNAJDER, 1998, p.112), o conceito de flor sendo considerado como uma estrutura presente tanto nas angiospermas como nas gimnospermas, ao dar a seguinte definição: “As angiospermas são fanerógamas com flores típicas, ao contrário das gimnospermas, em que as flores estão representadas por cones ou estróbilos, que popularmente não são chamados de flores”. Posteriormente, o conceito de flor é retomado, como sendo constituído por folhas especializadas encarregadas da reprodução. (ibid., p. 455) 
Finalmente, na coleção Bio - Introdução ao estudo dos seres vivos, Ed. Saraiva, (LOPES, 2003, p.133), afirma que flores são "estruturas bem evidentes e relacionadas com a reprodução sexuada das angiospermas”.

Aparentemente há um consenso entre os autores, ao afirmarem que a flor é uma estrutura composta de folhas modificadas. Mas, o mesmo não se dá em relação ao grupo em que a estrutura flor pertence.

Em relação ao conceito de fruto, utilizamos a mesma estratégia que foi usada para a análise do conceito de flor, já citada anteriormente (vide análise do item Q1q10). Na tab. 6, logo abaixo, podemos perceber que o conceito de fruto está mais voltado para a sua funcionalidade, tendo, ao mesmo tempo, um número considerável de citações da sua origem, a partir do "ovário desenvolvido" da flor.

Tabela 6. Categorização do conceito de fruto do ingressantes do CBio/USP/2006.

\begin{tabular}{llc}
\hline Categoria & Item & N. $^{\text {o de ocorrências }}$ \\
\hline \multirow{2}{*}{ Grupos Taxonômicos } & Plantas (senso amplo) & 8 \\
& Angiospermas & 5 \\
& Fanerógamas & 1 \\
\hline \multirow{2}{*}{ Características } & Apresenta sementes & 21 \\
& Apresenta embrião & 9 \\
& Seco (não-carnoso) & 1 \\
& Partenocárpico & 1 \\
\hline \multirow{2}{*}{ Função } & Carnoso & 1 \\
\hline Fenômenos & Dispersão & 11 \\
& Proteção do embrião & 6 \\
& Reserva nutritiva & 5 \\
& Envoltório & 4 \\
\hline
\end{tabular}


Conclusão

Tabela 6. Categorização do conceito de fruto do ingressantes do CBio/USP/2006.

\begin{tabular}{llc}
\hline Categoria & Item & N. $^{\text {o de ocorrências }}$ \\
\hline \multirow{3}{*}{ Origem } & Flor & 13 \\
& Ovário fecundado & 7 \\
& Hormônio & 3 \\
& Óvulo fecundado & 2 \\
\hline Conceito & Órgão & 5
\end{tabular}

Nota - (1) Foram consideradas 51 respostas para a tabulação dos dados. (2) Às vezes, o mesmo termo aparece mais de uma vez na resposta do entrevistado.

Nas respostas analisadas, há um consenso entre os alunos de que o fruto deriva da flor ou de alguma parte relacionada diretamente a ela. Mas, como vimos anteriormente, o conceito de flor não está claro para os Ingressantes do CBio/USP/2006, o que gera também um conflito em relação ao conceito de fruto, haja vista que são interligados ao grupo das angiospermas, mesmo quando estudados em separado. Esses conflitos são percebidos também através dos gráficos 8 e 10.

Em relação, ainda, às respostas abertas dos entrevistados, apresentamos algumas das respostas analisadas, onde é possível percebermos essas associações citadas acima. Vejamos:

"Um fruto é o ovário da flor desenvolvido. Sendo uma maneira de dispersão das sementes das plantas". (FFA/012/2006) (negrito meu)

“Órgão que envolve sementes”. (FFA/022/2006) (negrito meu)

“Órgão das angiospermas, com desenvolvimento posterior ao da flor". (FFA/044/2006) (negrito meu) 
Em alguns casos, percebemos que o conceito de fruto está associado ao desenvolvimento do óvulo, como se o fruto derivasse do óvulo e não do ovário da flor. É o que acontece nos casos abaixo. Vejamos:

"Fruto é o óvulo de uma flor que após a fecundação desenvolve-se em fruto, com exceção dos frutos partenocárpicos, que não são fecundados" (FFA/039/2006) (negrito meu)

“óvulo fecundado e desenvolvido” (FFA/035/2006) (negrito meu)

No caso do entrevistado FFA/039/2006, há ainda um resgate da informação de que o fruto pode vir a desenvolver-se sem a formação de sementes (partenocárpico), conceito este explorado pelo Vestibular da Fuvest, Fig. 6, como já apontado no início deste capítulo, mas não consegue desvincular o conceito de fruto do conceito de óvulo fecundado.

Em relação à questão T1q15: “A seguir são apresentadas 5 imagens. Considerando o $\underline{\text { seu conhecimento sobre o conceito de fruto, circule em cada uma das imagens a(s) }}$ estrutura(s) que você considera como sendo um fruto. Não marque nada nas imagens em que você não identificar, pelo menos, um fruto", tivemos os seguintes resultados apresentados na tab. 7: 
Tabela 7. Respostas dos Ingressantes do CBio/USP/2006, obtidas em relação ao item T1q15, quando solicitados a circundar o que eles consideram como sendo "um fruto".

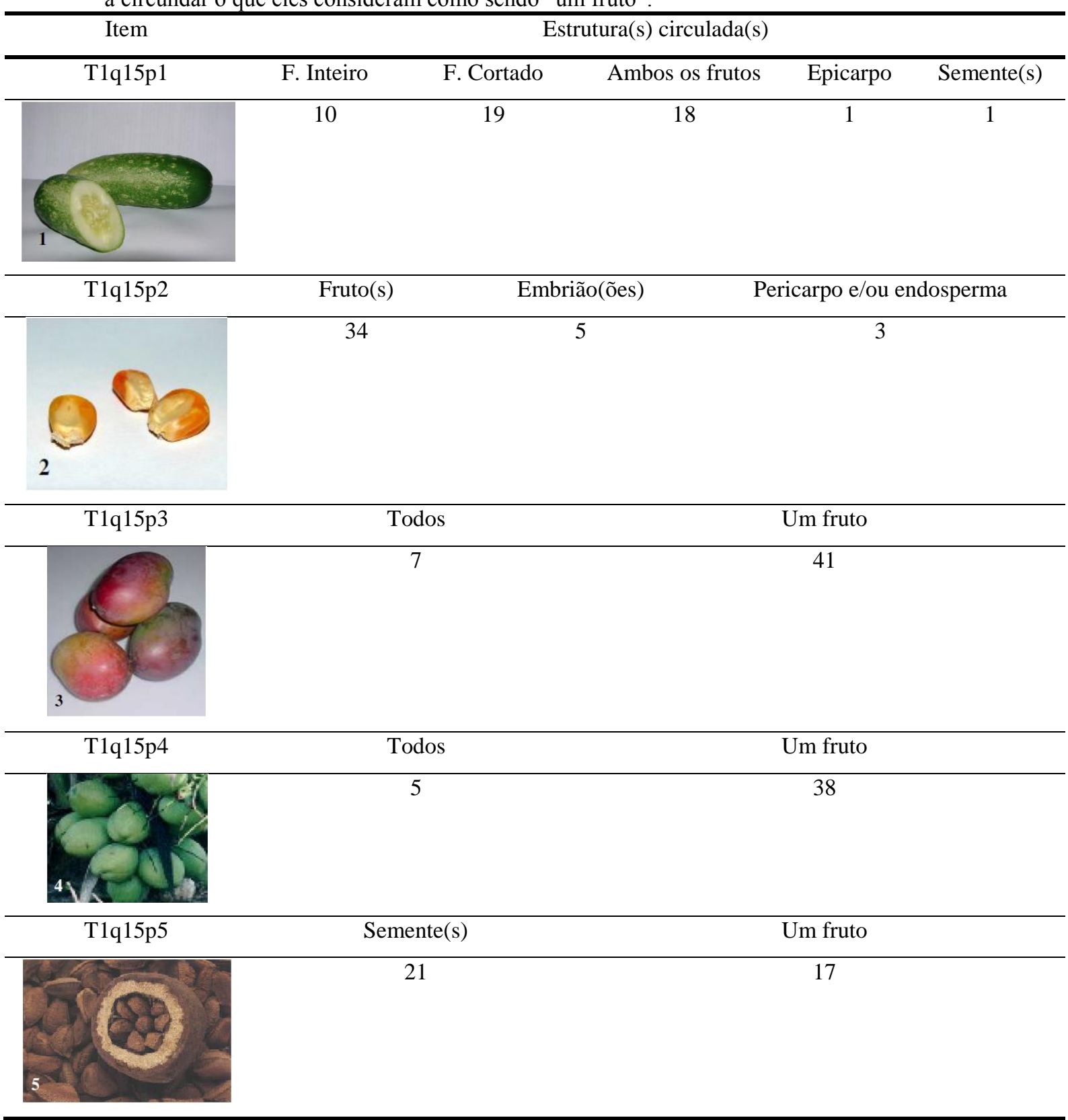

Nota - (1) Foram consideradas 51 respostas para a tabulação dos dados.

Apresentamos abaixo algumas das respostas dos entrevistados de FFA/0410109 em relação ao item T1q15. São as respostas dos entrevistados FFA/021/2006 (Fig. 8), FFA/032/2006 (Fig. 9), FFA/035/2006 (Fig. 10) e FFA/044/2006 (Fig. 11). 
Para o entrevistado FFA/021/2006 (Fig. 8), apenas as "sementes" no caso dos itens T1q15p1 e T1q15p5 representam para ele o que o mesmo considera como sendo "um fruto". Considerou a região do "embrião" como sendo um fruto, no caso do item T1q15p3.

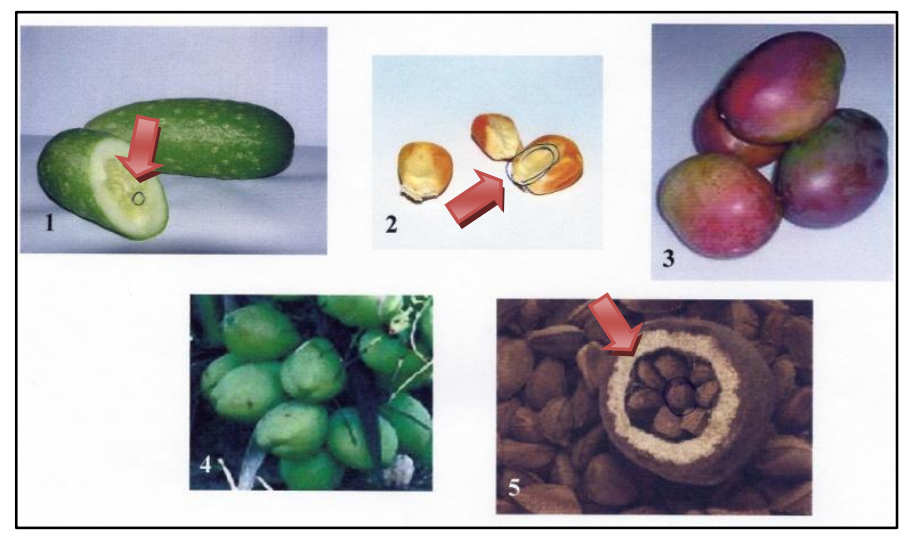

Figura 8. Respostas do entrevistado FFA/021/2006 ao item T1q15, sobre o que ele considera como sendo um fruto. As setas em vermelho indicam as marcações do entrevistado.

Em relação às respostas do entrevistado FFA/032/2006 (Fig. 9), as que se destacam são as dadas aos itens T1q15p2 e T1q15p5. No caso do item T1q15p2, apesar de em um primeiro momento ele considerar o fruto todo, o mesmo depois refaz as suas considerações, e cita que o que ele considera apenas como fruto no milho é a "CASCA", melhor dizendo, o pericarpo. No caso do item T1q15p5, o que entrevistado destaca como "TODAS AS CASTANHAS”, na verdade são as sementes. O fruto não é considerado pelo entrevistado. Aproveitando a oportunidade de exemplificação, no item T1q15p1, o entrevistado assinala “ambos os frutos", categoria criada por nós, para distinguir os vários tipos de respostas que obtivemos com este teste. No caso dos itens T1q15p3 e T1q15p4, o entrevistado assinala "todos" os frutos. 


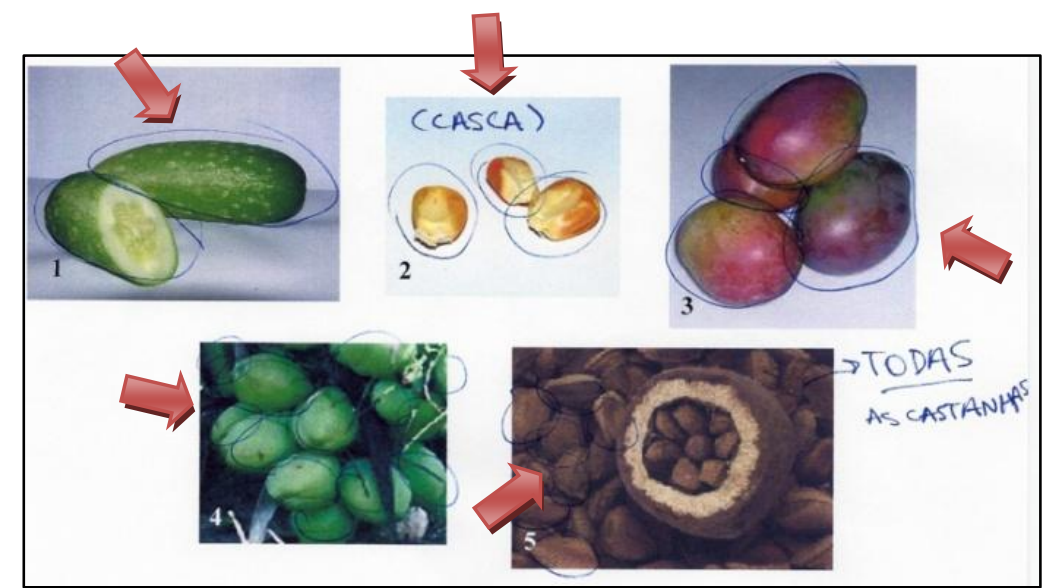

Figura 9. Respostas do entrevistado FFA/032/2006 ao item T1q15, sobre o que ele considera como sendo um fruto. As setas em vermelho indicam as marcações do entrevistado.

Por sua vez, o entrevistado FFA/035/2006 apresenta como respostas ao item T1q15 (Fig. 10), o "fruto cortado" (T1q15p1), o "pericarpo e/ou endosperma" (T1q15p2), o "fruto" (T1q15p3), não considerou o item T1q15p4, pois não assinalou o mesmo, e, a(s) "semente(s)" para o item T1q15p5. Para o item T1q15p2, o entrevistado destaca o pericarpo juntamente com o endosperma.

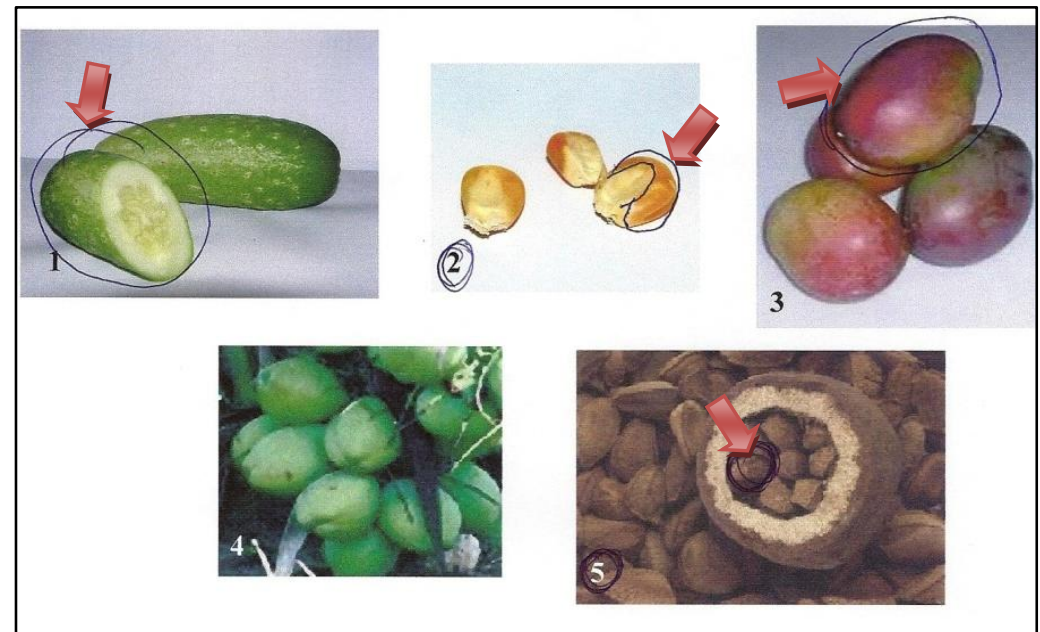

Figura 10. Respostas do entrevistado FFA/035/2006 ao item T1q15, sobre o que ele considera como sendo um fruto. As setas em vermelho indicam as marcações do entrevistado. 


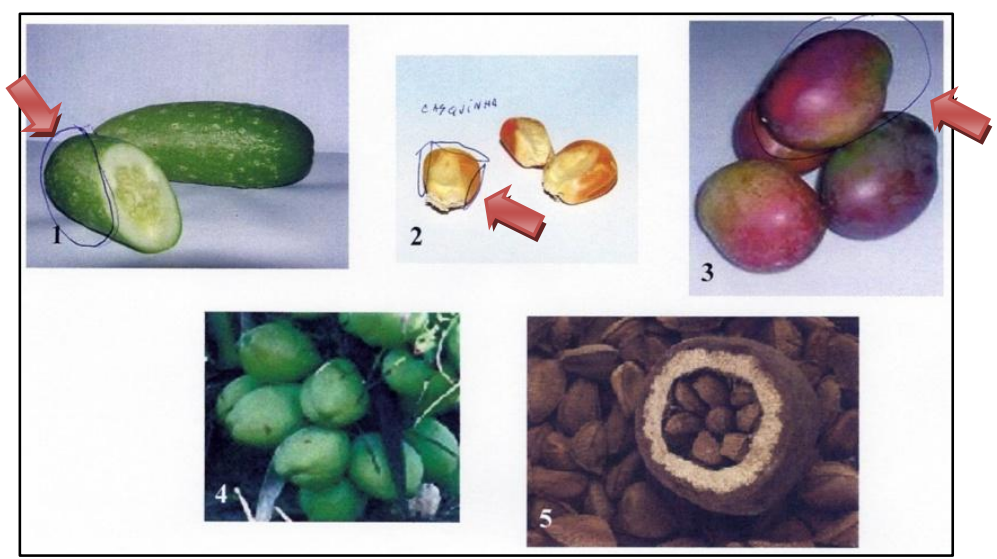

Figura 11. Respostas do entrevistado FFA/044/2006 ao item T1q15, sobre o que ele considera como sendo um fruto. As setas em vermelho indicam as marcações do entrevistado.

Finalmente, no caso do entrevistado FFA/044/2006, o que mais chama a atenção é o fato dele considerar apenas a parte mais externa do fruto, ou seja, o epicarpo (Fig. 11), tanto para o item T1q15p1 como para o item T1q15p2. Também considera como "fruto" o item T1q15p3. Não assinalou nada nos itens T1q15p4 e T1q15p5.

Em relação ao item T1q15p2, nenhum dos quatro casos, considerou toda a estrutura do milho como sendo um fruto. Todos destacaram que o "fruto" em suas concepções, nada mais era do que a região onde encontramos o embrião (Fig. 8) ou, a área destinada à reserva nutritiva (Figuras 9, 10 e 11), que os mesmos denominaram de "casca" ou "casquinha". Neste caso, o milho (Zea mays) é considerado um fruto do tipo "cariopse, ou seja, uma única semente unida à parede do fruto em toda a sua extensão" (AMABIS \& MARTHO, 2004, p. 175).

Para finalizarmos este item, podemos perceber que os entrevistados apresentam um conceito de flor vinculado ao senso comum (órgão comum a todas as plantas).

Por sua vez, o conceito de estróbilo é algo confuso também, pois os ingressantes do CBio/USP/2006 não conseguem ter um parâmetro único para afirmarem com convicção que o estróbilo não pertence ao grupo das Angiospermas. O termo inflorescência é também 
desconsiderado no momento em que os mesmos fazem as suas considerações nas pranchas (T1q15).

Já em relação ao conceito de fruto, o que nos parece bastante claro neste momento, é que o mesmo aparece associado a outros três conceitos: "sementes", "fecundação" e "ovário desenvolvido" (vide tabela 6). Mas, no momento em que eles são convidados a colocar em uso os conceitos, as dúvidas aparecem mais nitidamente (figuras 8 a 11). No caso do fruto seco, representado pela castanha-do-pará (Bertholletia excelsa) e do fruto cariopse, representando pelo milho (Zea mays) as confusões são demarcadas por falas do tipo "todas as castanhas", "a casca, apenas".

Isso demonstra, para nós, que o conceito de fruto for apenas interiorizado "mecanicamente" sem que o sujeito da aprendizagem soubesse qual o seu verdadeiro significado. Ao chegar no ensino superior, como os entrevistados ainda não possuem um vinculo com a Instituição, apresentam-se confusos sobre qual referencial adotar para responderem o questionário ("fala" dos livros didáticos, das apostilas, dos professores, ou as suas próprias vivências).

\subsection{Ingressantes do curso de Ciências Biológicas da USP (CBio/USP/2006) após um ano}

Apresentaremos aqui os gráficos produzidos a partir da análise do questionário $(\mathrm{Q} 2)$ e, em seguida, as tabelas com as "falas" dos sujeitos da aprendizagem organizadas em agrupamentos pela afinidade dos discursos.

Para retomar o contexto: este questionário foi aplicado nos alunos da Disciplina Morfologia e Anatomia de Vasculares (BIB0121) (MAPV/0121), na primeira aula da mesma, no período matutino. 
Q2q1: Este é o seu segundo ano na USP, como aluno do Curso de Ciências

Biológicas?

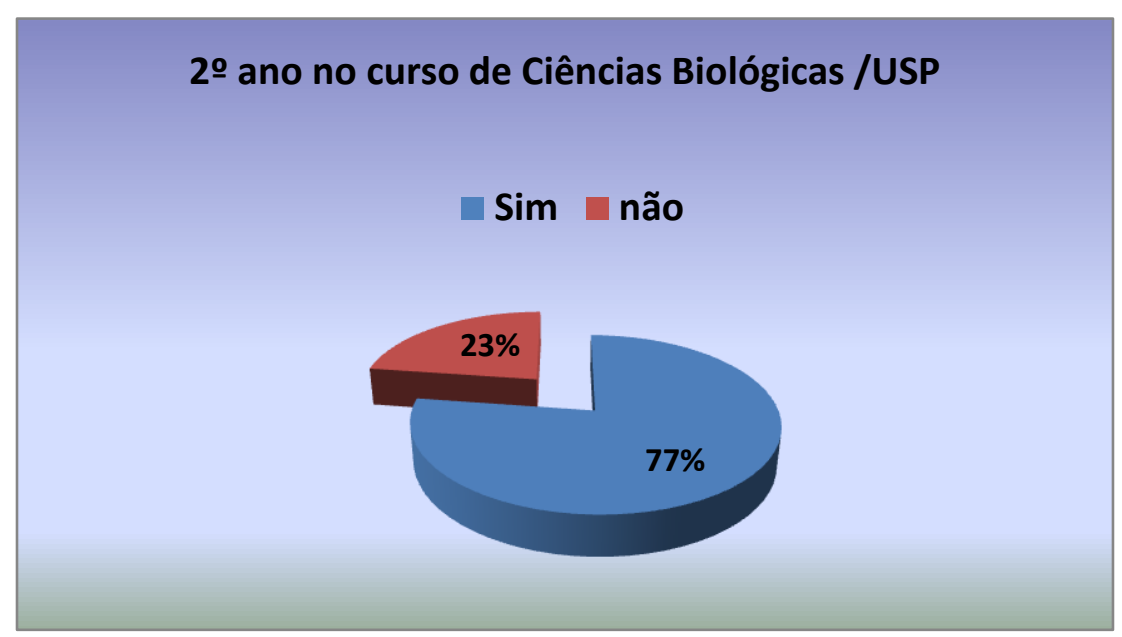

Gráfico 11. Porcentagem dos entrevistados que estavam cursando pela primeira vez o segundo ano, no curso de Ciências Biológicas da USP. Amostra composta por 66 respostas.

Para a tabulação dos dados gerados pelas questões seguintes, criamos uma condição no banco de dados ${ }^{37}$ para que, ao gerar o relatório, fossem considerados apenas os dados dos alunos que estavam cursando pela primeira vez o $2^{\circ}$ ano do CBio/USP. Portanto, esta pergunta nos permitiu separar os ingressantes CBio/USP/2006 dos outros alunos que estavam cursando a Disciplina MAPV/0121 por motivos de Mestrado, Dependência, ou como Alunos Especiais.

Q2q2: Ao longo deste período em que você se encontra na USP, cursando Ciências Biológicas, você já teve alguma disciplina que abordou os conceitos de flor e fruto? (Se sim, indique na frente a(s) disciplina(s).)

\footnotetext{
${ }^{37}$ Essa ferramenta é oferecida pelo próprio programa Access ${ }^{\circledR} 2007$.
} 


\section{Alguma disciplina abordou os temas Flor e Fruto,} antes?

\section{घim $\square$ não}

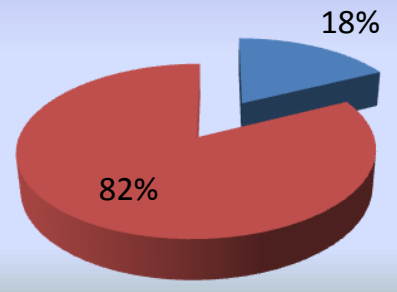

Gráfico 12. Porcentagem dos entrevistados que afirmam que tiveram os conceitos de 'flor' e de 'fruto' abordados em disciplinas anteriores. Amostra composta por 51 respostas.

Em relação às respostas do gráfico 12 , entre os entrevistados que afirmaram que tiveram os conceitos de 'flor' e de 'fruto', e, neste caso, cada aluno indicou apenas uma disciplina, obtivemos a seguinte tabela abaixo:

Tabela 8. Disciplinas que abordaram os conceitos de 'flor'e de 'fruto' em 2006 apontadas pelos entrevistados da disciplina MAPV/0121

\begin{tabular}{lcc}
\hline \multicolumn{1}{c}{ DISCIPLINA } & Qt & $\%$ \\
\hline Fauna, Flora e Ambiente & 4 & 44.4 \\
Morfologia e Taxonomia de Criptogamas & 3 & 33.3 \\
Plantas Medicinais & 1 & 11.1 \\
Não citou a disciplina & 1 & 11.1 \\
Total & 9 & 100.0 \\
\hline
\end{tabular}

O interessante na tab. 8 é o fato de aparecer, entre as disciplinas citadas, a Disciplina Taxonomia de Criptógamas - BIB0120 (TC/0120), pois a mesma, não tem como tema 
principal os conceitos de 'flor' e de 'fruto' no seu programa curricular ${ }^{38}$. Muito pelo contrário, o objetivo desta disciplina é

\begin{abstract}
Fornecer um panorama amplo, básico e atualizado da classificação dos organismos dos reinos Monera e Protista fotossintetizantes, Plantae e Fungi, com ênfase na conceituação e critérios taxonômicos, caracterização vegetativa e reprodutiva. Tendências evolutivas gerais e de grupos taxonômicos em níveis superiores (Divisão, classe e subclasse), com base em critérios da morfologia vegetativa e da reprodução, citológicos e bioquímicos. Abrir perspectivas para temas de áreas da fisiologia, biologia, ecologia e recursos econômicos. (USP/2010)
\end{abstract}

Quando analisado em detalhe o programa, apesar de aparecer o Reino Plantae como objeto de estudo, os responsáveis pela disciplina não incluem os grupos 'gimnosperma' e 'angiosperma', justamente por se tratar de objeto de estudo da Disciplina MAPV/0121.

Entre as outras Disciplinas, FFA/0410109, é uma das mais citadas. Neste caso, há a possibilidade de os ingressantes do CBio/USP/2006 terem tido o conceito em outro contexto, diferente do abordado pela Disciplina MAPV/0121, haja vista que o objetivo da FFA/0410109 é

Prover ao aluno um contato com os seres vivos em seus ambientes naturais, analisando-os sob uma ótica biológica. Despertar o aluno para as principais questões que o biólogo procura responder para entender a natureza, fornecendo noções dos princípios e fundamentos metodológicos para resolvê-los. (USP/2010) ${ }^{39}$

No programa resumido ${ }^{40}$ (USP/2010) da FFA/0410109, item 5, encontramos como um dos grandes temas de discussão a informação "Obtenção de dados em estudos da fauna,

\footnotetext{
${ }^{38}$ o Programa da disciplina se encontra disponibilizado em: <http://felix.ib.usp.br/Grad3.htm>. Acessado em: 19 jan. 2010.

${ }^{39}$ Vide nota 38.

${ }^{40}$ Idem nota anterior.
} 


\section{flora e vegetação. Subsídios para o reconhecimento dos grandes grupos de organismos;} adaptações ao meio; formas de vida; ciclos de vida" (negrito meu).

Neste caso, como a disciplina FFA/0410109 procura dividir os seus grandes temas entre os estudantes matriculados na referida disciplina, há a possibilidade de um número pequeno, mas considerável, ter abordado na pesquisa de campo da disciplina ${ }^{41}$, alguns dados relacionados aos conceitos de 'flor' e de 'fruto'.

Q2q3: Você já desenvolveu algum tipo de estágio em laboratório e/ou pesquisa de campo, onde o seu tema principal foi a pesquisa com plantas vasculares, mais $\underline{\text { especificamente, angiospermas? (Se sim, indique na frente o estágio e o seu orientador) }}$

Gráfico 13. Porcentagem dos entrevistados que fizeram estágio, com enfoque em plantas superiores. Amostra composta por 51 respostas.

Apenas um entrevistado fez estágio, em Anatomia Vegetal, com o Prof. Dr. Gregório Cardoso Tápias Ceccantini. Todos os outros cinquenta entrevistados disseram que não.

\footnotetext{
41 A disciplina Fauna, Flora e Ambiente inclui uma pesquisa de campo na qual os estudantes devem desenvolver um projeto focado em interações biológicas.
} 
O fato de este entrevistado ter contato com o Laboratório de Anatomia Vegetal, antes mesmo de realizar a Disciplina MAPV/0121 pode ser um indicativo de que o tema, para o mesmo é de extremo interesse.

Q2q4: Levando em consideração a sua formação educacional, você acredita ser capaz $\underline{\text { de reconhecer visualmente uma Flor? }}$

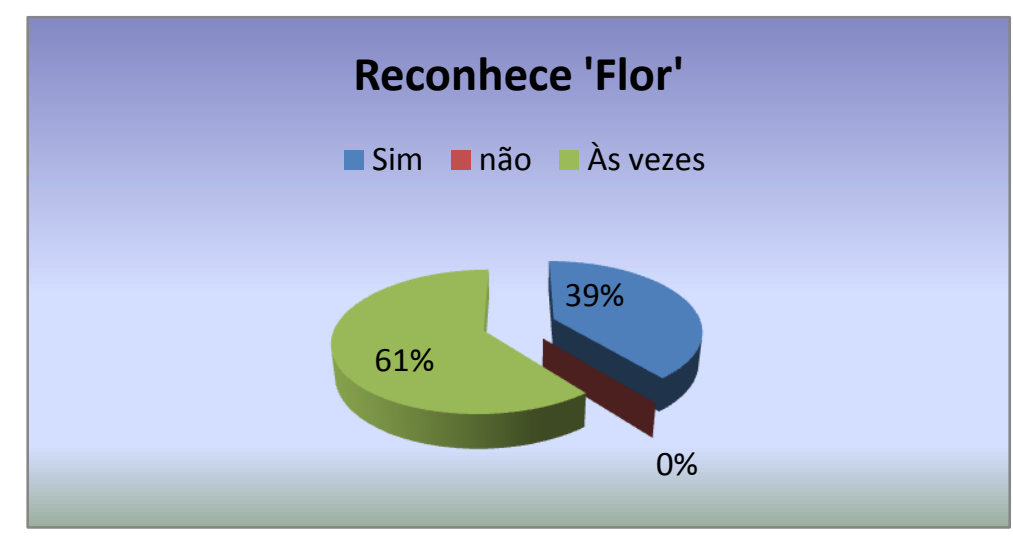

Gráfico 14. Porcentagem dos entrevistados que afirmam reconhecer sempre ou às vezes, uma flor. Amostra composta por 51 respostas.

Comparando o gráfico 14 com o gráfico 8, podemos perceber uma pequena flutuação nos dados, no sentido de um aumento de $7.9 \%$ para a resposta 'Às vezes'. Esse aumento na incerteza, provavelmente se deu pelo próprio convívio dos ‘sujeitos da aprendizagem' com o universo acadêmico; outra possibilidade é o 'amadurecimento' do 'sujeito da aprendizagem' em relação a sua formação profissional; 
Na sequência, vem o item Q2q5. Este será abordado juntamente com o item Q2q7, pelo fato de se tratar das perguntas abertas do questionário e também pelo fato de a metodologia empregada na análise das mesmas ser diferenciada ${ }^{42}$ (Item 4.2.1).

Q2q6: Levando em consideração a sua formação educacional, você seria capaz de reconhecer visualmente um Fruto?

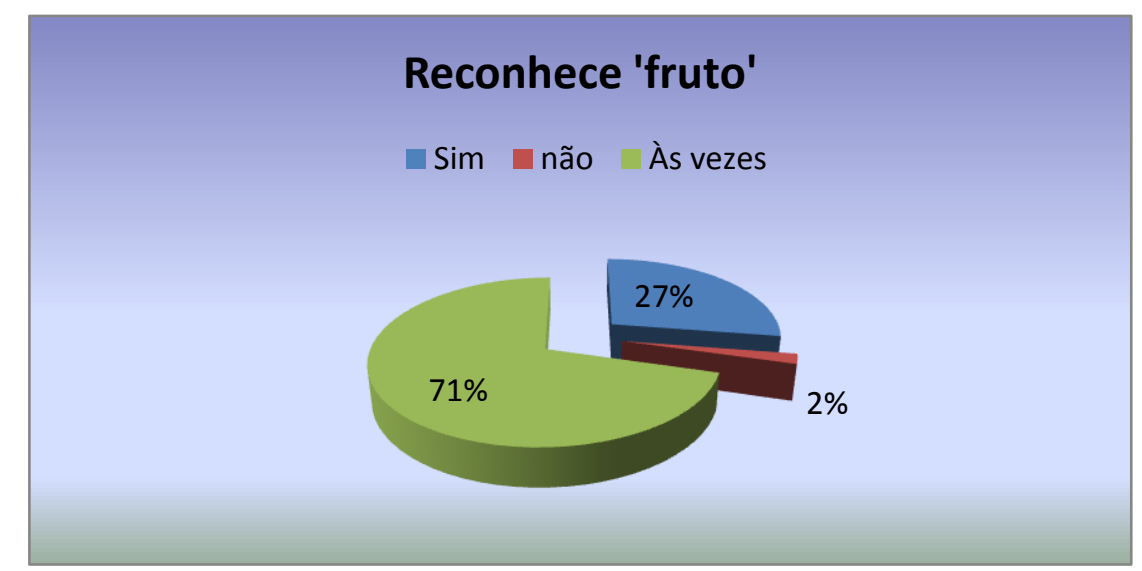

Gráfico 15. Porcentagem dos entrevistados que afirmam reconhecer sempre, às vezes ou não, um fruto. Amostra composta por 51 respostas.

No gráfico 15, comparando-o com o gráfico 10, percebemos que surge um elemento novo, o fato de um dos entrevistados dizer que não conseguiria reconhecer "fruto". Outro dado que também sofreu aumento, foi o item 'Às vezes', com um acréscimo de $2 \%$, em relação aos dados coletados no ano anterior. Consequentemente, o item sim, sofreu uma redução de 4\%, comparado com os dados coletados no ano anterior. As conjecturas sobre essa variação nos valores é a mesma do item Q2q4.

${ }^{42}$ Vide cap. 3. 


\subsubsection{Os conceitos de flor e de fruto presentes no discurso dos ingressantes CBio/USP/2006 após um ano na USP}

O item Q2Q5: "Na sua opinião, qual a melhor maneira de se conceituar uma Flor?", foi retomado agora com o objetivo de analisarmos o conceito de flor apresentado pelos entrevistados, permitindo-nos verificar e comparar os conceitos morfológicos de flor com os dos Ingressantes do CBio/USP/2006. Na medida do possível, procuramos manter as mesmas categorias, haja vista que o signo analisado é o mesmo. Por sua vez, os entrevistados também não trouxeram novas categorias para a discussão. Os dados obtidos foram transpostos para a tab. 9. Vejamos:

Tabela 9. Categorização do conceito de flor pelos entrevistados da disciplina MAPV/0121

\begin{tabular}{llc}
\hline CATEGORIA & \multicolumn{1}{c}{ ITEM } & N. $^{\circ}$ DE OCORRÊNCIAS \\
\hline \multirow{3}{*}{ Grupos Taxonômicos } & Plantas (senso amplo) & 19 \\
& Plantas Vasculares & 15 \\
& Fanerógamas & 3 \\
& Espermatófitas & 1 \\
& Pétala & 1 \\
\hline & Ovário & 4 \\
& Antera & 4 \\
Partes constituintes da flor & Androceu & 3 \\
& Gineceu & 2 \\
& Anterídeo & 2 \\
& Sépala & 2 \\
Corola & 2 \\
Gameta(s) masculinos & 2 \\
Gametófito feminino & 1 \\
Gametófito masculino & Geração gametofítica & 1 \\
\hline
\end{tabular}


Conclusão

Tabela 9. Categorização do conceito de flor pelos entrevistados da disciplina MAPV/0121

\begin{tabular}{|c|c|c|}
\hline CATEGORIA & ITEM & N. ${ }^{\circ}$ DE OCORRÊNCIAS \\
\hline \multirow{6}{*}{ Partes constituintes da flor } & Pedúnculo & 1 \\
\hline & Esporófito & 1 \\
\hline & Estipe & 1 \\
\hline & Útero & 1 \\
\hline & Células germinativas & 1 \\
\hline & Oosfera & 1 \\
\hline \multirow{11}{*}{ Características } & Órgão/Aparelho reprodutor & 20 \\
\hline & Estrutura reprodutiva & 14 \\
\hline & Aparelho reprodutor feminino & 6 \\
\hline & Aparelho reprodutor masculino & 6 \\
\hline & Colorida & 5 \\
\hline & Órgão & 4 \\
\hline & Fase gametofítica & 3 \\
\hline & Órgão sexual & 2 \\
\hline & Apresenta cheiro/aroma & 2 \\
\hline & Estrutura de suporte/ sustentação & 1 \\
\hline & Receptáculo & 1 \\
\hline \multirow{8}{*}{ Função } & Transforma-se em fruto & 5 \\
\hline & Reprodutiva & 4 \\
\hline & Atrativa & 3 \\
\hline & Formar sementes & 3 \\
\hline & Abrigar & 2 \\
\hline & Reprodução sexuada & 1 \\
\hline & Desenvolver o embrião & 1 \\
\hline & Proteger & 1 \\
\hline \multirow{2}{*}{ Fenômenos } & Polinização & 3 \\
\hline & Fecundação & 2 \\
\hline Ontogênese & Folha Modificada & 3 \\
\hline
\end{tabular}

Nota - (1) Foram consideradas 51 respostas para a tabulação dos dados. (2) Às vezes, o mesmo termo aparece mais de uma vez na resposta do entrevistado.

Neste segundo momento, percebemos uma mudança no conceito de flor, onde o mesmo passa a se voltar para as angiospermas, exclusivamente (37.3\%). Como exemplos de respostas dadas, citamos as abaixo: 
“Órgão reprodutor de plantas angiospermas” (MAPV/049/2007) (negrito meu)

“Flor é a estrutura reprodutiva das angiospermas" (MAPV/065/2007) (negrito meu)

"Flor é o conjunto de órgãos reprodutores em angiospermas.” (MAPV/057/2007) (negrito meu)

O termo flor atrelado a uma planta (senso amplo) ainda é muito presente nas falas dos entrevistados, com $29.1 \%$ das respostas apresentadas. Segue abaixo algumas das respostas dadas pelos entrevistados:

"Uma flor é o órgão de uma planta, geralmente de cor chamativa e que abriga o aparelho reprodutivo desta." (MAPV/020/2007) (negrito meu)

“A estrutura que contém a estrutura reprodutiva da planta" (MAPV/050/2007) (negrito meu)

Comparando os dados obtidos (tab. 9) com os da tab. 4, percebemos que o conceito de flor vinculado às gimnospermas não aparece, com exceção de duas respostas apenas, onde os entrevistados se referem ao grupo das Fanerógamas (gimnospermas e angiospermas, respectivamente) e ao grupo das espermatófitas (plantas com sementes). Outro detalhe que nos chama a atenção, é o fato de os entrevistados citarem um termo novo - 'plantas vasculares', haja vista que nas respostas dos Ingressantes do CBio/USP/2006, não o tínhamos (tab. 4). Segue abaixo algumas das respostas que caracterizam o que acabamos de citar: 
"Flor seria a estrutura reprodutiva de uma fanerógama, responsável por promover a formação de sementes e frutos.” (MAPV/031/2007) (negrito meu)

"Flor é uma região de plantas espermatófitas em que teve as folhas modificadas com finalidade de reprodução.” (MAPV/039/2007) (negrito meu)

"São estruturas de suporte de órgãos reprodutores, nas plantas vasculares." (MAPV/019/2007) (negrito meu)

“É uma estrutura de plantas vasculares que envolve a geração gametofítica." (MAPV/064/2007) (negrito meu)

Aumenta-se o número de categorias relacionadas às funções das flores. Uma das possíveis causas pode ser vinculada ao fato dos entrevistados terem ampliado o seu repertório sobre a categoria ao cursarem disciplinas como, por exemplo, FFA/0410109 e TC/0120.

Em relação ao item T2q8: “A seguir são apresentadas 6 imagens. Considerando o seu $\underline{\text { conhecimento sobre o conceito de flor, circule em cada uma das imagens a(s) estrutura(s) que }}$ você considera como sendo uma flor. Não marque nada nas imagens em que você não identificar, pelo menos, uma flor.”, tivemos os seguintes resultados registrados na tab. 10: 
Tabela 10. Respostas dos entrevistados da disciplina MAPV/0121, obtidas em relação ao item T2q8, quando solicitados a circundar o que eles consideram como sendo "uma flor".

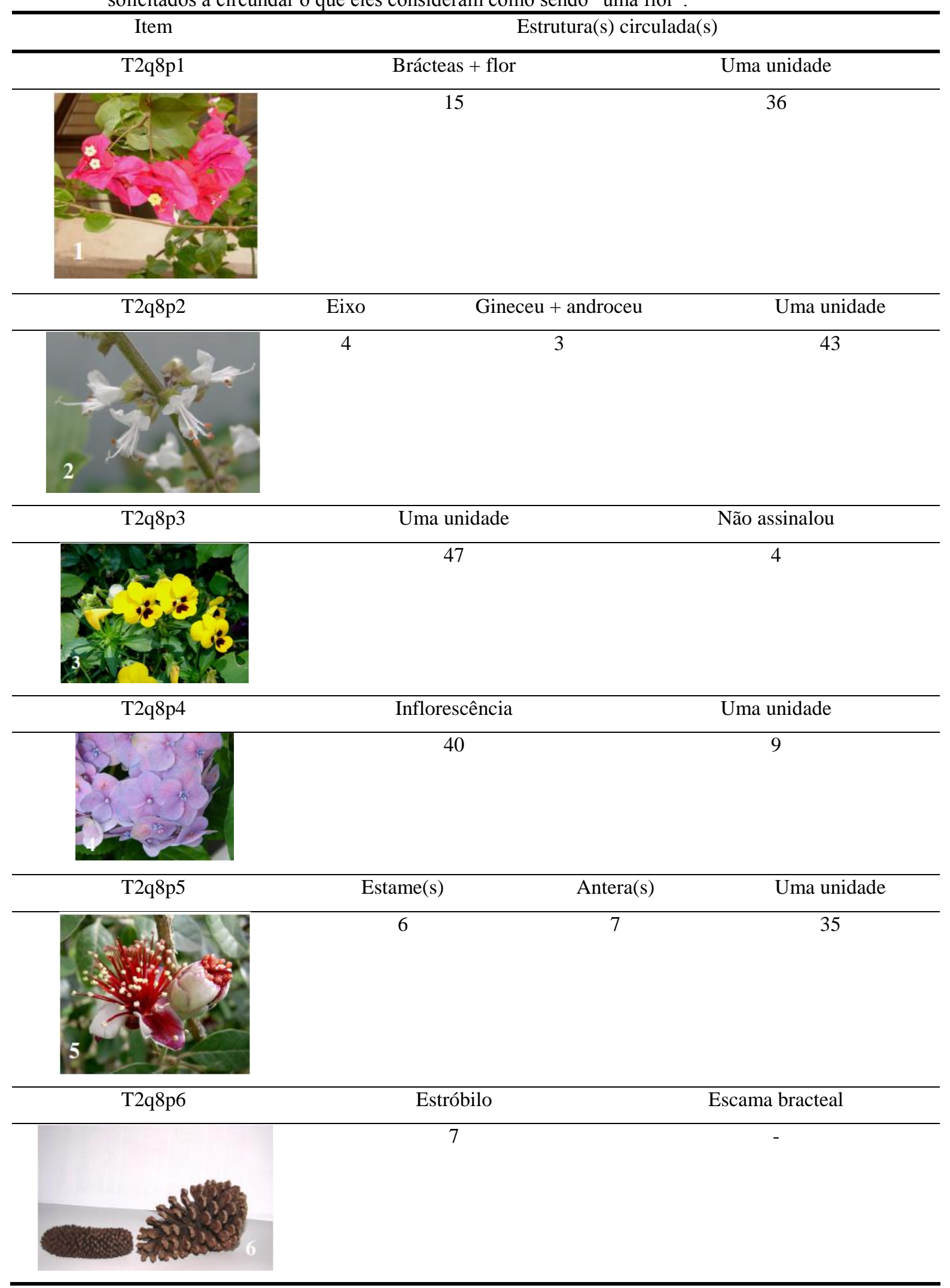

Nota - (1) Foram consideradas 51 respostas para a tabulação dos dados. 
Em relação aos testes podemos perceber que sete (7) entrevistados (MAPV/009/2007; MAPV/019/2007; MAPV/027/2007; MAPV/039/2007; MAPV/043/2007; MAPV/050/2007; MAPV/051/2007) ainda apresentam dificuldades em diferenciar um estróbilo de uma flor (tab. 10). Chamamos a atenção para as respostas dadas anteriormente, dos entrevistados MAPV/019/2007 e MAPV/039/2007, onde ambos trabalham com a ideia de que as plantas vasculares e as espermatófitas, respectivamente, apresentam flores. Como os conceitos de ambos incluem as gimnospermas, era esperado, de certa maneira, que incluíssem o estróbilo em suas respostas como sendo uma flor.

Também podemos notar que ainda aparecem conceitos derivados do 'senso comum' entre os entrevistados ao considerarem no item T2q8p1, os elementos 'brácteas + flor' como sendo todo o conjunto uma flor. Nos outros itens, como é o caso do item T2q8p3, quatro (4) entrevistados desconsideraram o mesmo. E, no item T2q8p5, o que destacamos é o fato de alguns considerarem apenas o(s) estame(s) ou a(s) antera(s).

Para ilustramos o que acabamos de discutir, destacamos as respostas do entrevistado MAPV/009/2007 em relação ao item T2q8. Vejamos:

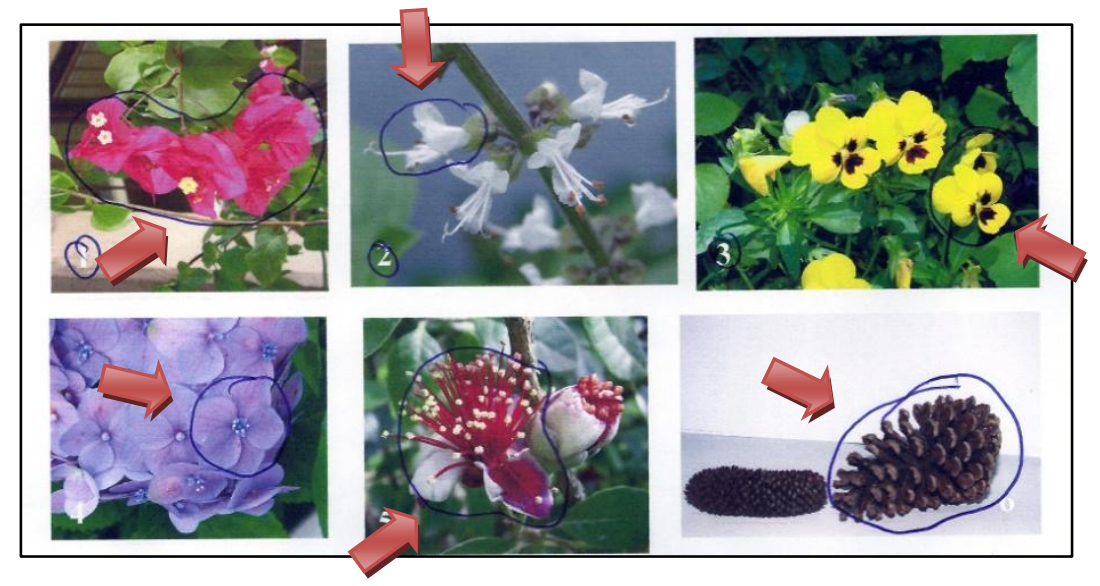

Figura 12. Respostas do entrevistado MAPV/009/2007 em relação ao item T2q8. As setas em vermelho indicam as marcações do entrevistado. 
No caso do entrevistado MAPV/009/2007 (Fig. 12), podemos perceber que o mesmo ainda apresenta algumas dificuldades em distinguir flor de estróbilo e de inflorescência, como apontado nos itens T2q8p1 e T2q8p6.

Apresentamos na tab. 11 os dados coletados em relação ao item Q2q7: $\mathrm{Na}$ sua opinião, qual a melhor maneira de se conceituar Fruto? Escreva em duas linhas.

Tabela 11. Categorização do conceito de fruto pelos alunos da disciplina MAPV/0121

\begin{tabular}{|c|c|c|}
\hline Categoria & Item & N. $^{\circ}$ de ocorrências \\
\hline \multirow{3}{*}{ Grupos taxonômicos } & Plantas (senso amplo) & 10 \\
\hline & Angiospermas & 7 \\
\hline & Gimnospermas & 2 \\
\hline \multirow{3}{*}{ Características } & Apresenta sementes & 28 \\
\hline & Apresenta embrião & 12 \\
\hline & Carnoso & 1 \\
\hline \multirow{5}{*}{ Função } & Proteção & 22 \\
\hline & Envoltório & 13 \\
\hline & Reserva nutritiva & 6 \\
\hline & Dispersão & 6 \\
\hline & Atração & 1 \\
\hline Fenômenos & Fecundação & 7 \\
\hline \multirow{8}{*}{ Origem } & Ovário desenvolvido & 28 \\
\hline & Flor & 7 \\
\hline & Ovário fecundado & 1 \\
\hline & Endosperma & 3 \\
\hline & Oosfera & 3 \\
\hline & Flor fecundada & 1 \\
\hline & Pistilo & 1 \\
\hline & Óvulo fecundado & 3 \\
\hline \multirow{2}{*}{ Conceito } & Órgão de fecundação & 1 \\
\hline & Órgão vegetal & 1 \\
\hline \multirow{4}{*}{ Composição } & Endocarpo & 1 \\
\hline & Endosperma & 2 \\
\hline & Epicarpo (“ectocarpo") & 1 \\
\hline & Mesocarpo & 1 \\
\hline
\end{tabular}

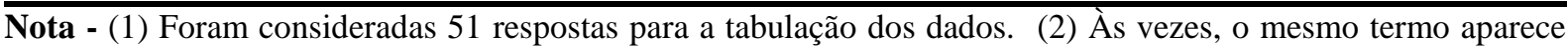
mais de uma vez na resposta do entrevistado. 
A origem e o grupo taxonômico são categorias muito frequentes nas "falas" dos entrevistados (Tab 11). A seguir exemplificamos algumas dessas "falas":

"fruto é o meio da planta dispensar sua semente, encontrado em gimno e angiospermas". (MAPV/048/2007) (negrito meu)

“fruto é uma flor fecundada e que protege e nutre o embrião. São encontrados em gimnospermas e angiospermas". (MAPV/047/2007) (negrito meu)

“abriga semente de certa planta". (MAPV/002/2007) (negrito meu)

Outros entrevistados pontuam a origem do fruto, como podemos observar abaixo:

"Fruto é o resultado do desenvolvimento do ovário, constituído de ectocarpo, mesocarpo e endocarpo que reveste total ou parcialmente a(s) semente(s)". (MAPV/070/2007) (negrito meu)

“fruto é o ovário desenvolvido após a fecundação da oosfera, que contém em seu interior a semente". (MAPV/065/2007) (negrito meu)

“estrutura proveniente do desenvolvimento do ovário, que protege e/ou auxilia na dispersão das sementes". (MAPV/056/2007) (negrito meu)

“fruto é o ovário desenvolvido". (MAPV/042/2007) (negrito meu) 
Os elementos destacados nas "falas" dos sujeitos nos permitem criar uma percepção de como eles veem o fruto e sua concepção. Neste caso, o foco maior ainda está voltado para as funções. O conceito de fruto partenocárpico, por exemplo, é esquecido pelos entrevistados e a ideia de que todo fruto apresenta semente aparece 28 vezes.

Já, em relação ao item T2q9: “A seguir são apresentadas 6 imagens. Considerando o $\underline{\text { seu conhecimento sobre o conceito de fruto, circule em cada uma das imagens a(s) }}$ $\underline{\text { estrutura(s) que você considera como sendo um fruto. Não marque nada nas imagens em que }}$ você não identificar, pelo menos, um fruto", obtivemos os seguintes resultados apresentados na tab. 12.

Tabela 12. Respostas dos entrevistados da disciplina MAPV/0121, obtidas em relação ao item T2q9, quando solicitados a circundar o que eles consideram como sendo "um fruto".

\begin{tabular}{ccccc}
\hline \multicolumn{5}{c}{ Estrutura(s) circulada(s) } \\
\hline Item & F. Inteiro & F. Cortado & Ambos os frutos & Semente(s) \\
\hline T2q9p1 & 6 & 27 & 8 & 5 \\
\hline & & & & \\
\hline \\
\hline
\end{tabular}




\section{Conclusão}

Tabela 12. Respostas dos entrevistados da disciplina MAPV/0121, obtidas em relação ao item T2q9, quando solicitados a circundar o que eles consideram como sendo "um fruto".

Item Estrutura(s) circulada(s)

\begin{tabular}{lccc}
\hline & Semente(s) & Um fruto \\
\hline T2q9p4 & 18 & 18 \\
\hline \\
\hline
\end{tabular}

Nota - (1) Foram consideradas 51 respostas para a tabulação dos dados.

Comparando os dados obtidos da tab. 12 com os dados presentes na tab. 7, podemos perceber em relação aos itens T1q15p1 e T2q9p1 que houve pequenas mudanças, como não considerarem mais o pericarpo como sendo um fruto, mas, aparece como respostas em um número maior, a ideia de que as sementes do pepino são os frutos, neste caso (cinco respostas $)^{43}$.

Para o item T2q9p2, podemos perceber um número maior de incertezas ao compararmos com as respostas do item T1q15p2, ou seja, enquanto no item T1q15p2 tivemos

\footnotetext{
${ }^{43}$ No primeiro questionário, apenas um entrevistado considerou a semente como sendo um fruto (Fig. 8 / Tab. 7).
} 
9 (nove) entrevistados que não consideraram o milho (Zea Mays) como fruto, no item T2q9p2, aparecem dezenove (19) entrevistados como dúvidas sobre o milho (Zea Mays).

Em relação ao item T2q9p3, a prancha presente não esteve no primeiro questionário. Portanto, não é passível de comparações com o questionário anterior, mas, podemos perceber que mesmo se tratando de uma infrutescência, ainda assim, os entrevistados apresentam dúvidas sobre a sua estrutura, pois tivemos quatorzes (14) entrevistados que afirmaram que o conjunto de frutos representa apenas um fruto.

Já para o item T2q9p4, as dúvidas ainda permanecem. Muitos ainda consideram a semente como fruto.

Em relação ao item $\mathbf{T} 2 \mathbf{9 9} \mathbf{p 5}$, tivemos um número considerável de entrevistados (58.8\%) que consideraram apenas o fruto verdadeiro como um fruto. Mas, ainda assim, podemos perceber que existem alguns entrevistados com dúvidas sobre o que considerar como um fruto verdadeiro $(41.2 \%)$, pois $17.6 \%$ disseram que toda a estrutura (pseudofruto +fruto) corresponde a um fruto e $13.7 \%$ consideram apenas o pseudofruto como um fruto. Finalmente, $9.8 \%$ não assinalaram o item.

Finalmente, em relação ao item T2q9p6, tivemos apenas seis (6) entrevistados que consideraram a semente do abacate como sendo um fruto e um entrevistado que não considerou o abacate como sendo um fruto.

A seguir, colocamos as respostas de alguns entrevistados (MAPV/001/2007; MAPV/033/2007). 


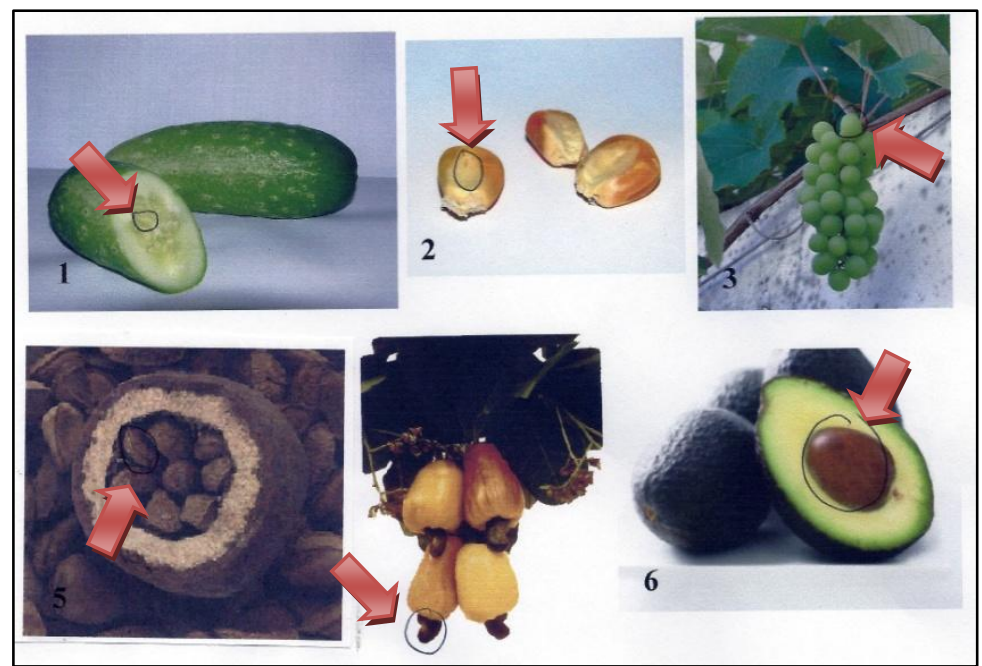

Figura 13. Respostas do entrevistado MAPV/033/2007 ao item T2q9, sobre o que ele considera como sendo um fruto. As setas em vermelho indicam as marcações do entrevistado.

Neste caso, o entrevistado MAPV/033/2007 apresenta uma tendência a considerar apenas a semente como sendo um fruto, haja vista as suas anotações apresentadas na Fig. 13. Nela podemos observar que o entrevistado assinalou a semente nos itens T2q9p1, T2q9p4 e T2q9p6. No item T2q9p2, considera apenas uma pequena região do grão de milho, considerada por nós como sendo a região do embrião. Nos itens T2q9p3 e T2q9p5, o entrevistado assinala apenas um fruto.

Já em relação às respostas do entrevistado MAPV/001/2007, temos os seguintes resultados observados na Fig. 14:

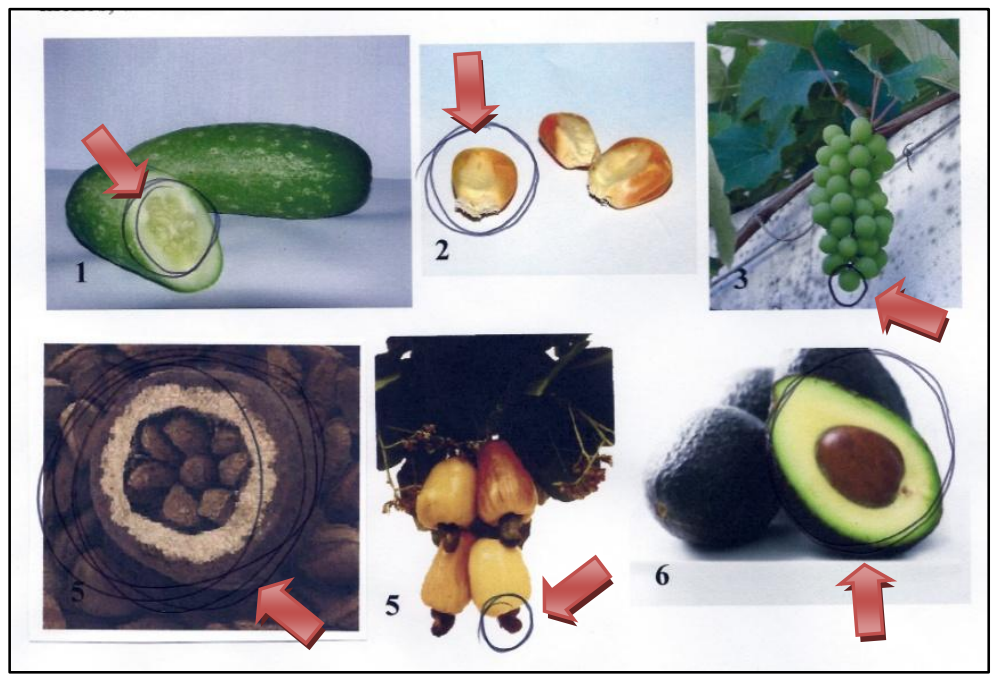

Figura 14. Respostas do entrevistado MAPV/001/2007 ao item T2q9, sobre o que ele considera como sendo um fruto. As setas em vermelho indicam as marcações do entrevistado. 
No caso do entrevistado MAPV/001/2007, parece-nos que o mesmo indicou as sementes do fruto no item T2p9p1. O mesmo não acontece com os outros itens, pois ele consegue distinguir um fruto em cada um dos cinco outros itens.

Finalizando esses comentários sobre o grupo de entrevistados na disciplina MAPV/0121/2007, podemos perceber que em relação à parte prática, se assim a podemos definir, apresenta poucas alterações em relação aos dados coletados no questionário anterior, sinalizando que os entrevistados apresentam as mesmas dúvidas que os ingressantes do CBio/USP/2006, se não na sua totalidade, pelo menos, na sua grande maioria.

\subsection{Ingressantes do curso de Ciências Biológicas da USP (CBio/USP/2006) após dois anos - estudantes da disciplina Taxonomia de Fanerógamas (TF/0123)}

Apresentaremos aqui os gráficos produzidos a partir da análise do questionário $(\mathrm{Q} 3)$ e, em seguida, as categorias das "falas" dos sujeitos da aprendizagem organizadas em agrupamentos pela afinidade dos discursos. Aproveitaremos para comparar as "falas" dos sujeitos da aprendizagem do início do curso (Ingressantes do CBio/USP/2006) com as "falas" agora, após dois anos de imersão no ensino superior.

Q3q1: Este é o seu segundo ano na USP, como aluno do Curso de Ciências Biológicas? (Se 'não', indique na frente quantos anos já está cursando Ciências Biológicas.) 


\section{2o ano no curso de C. B?}

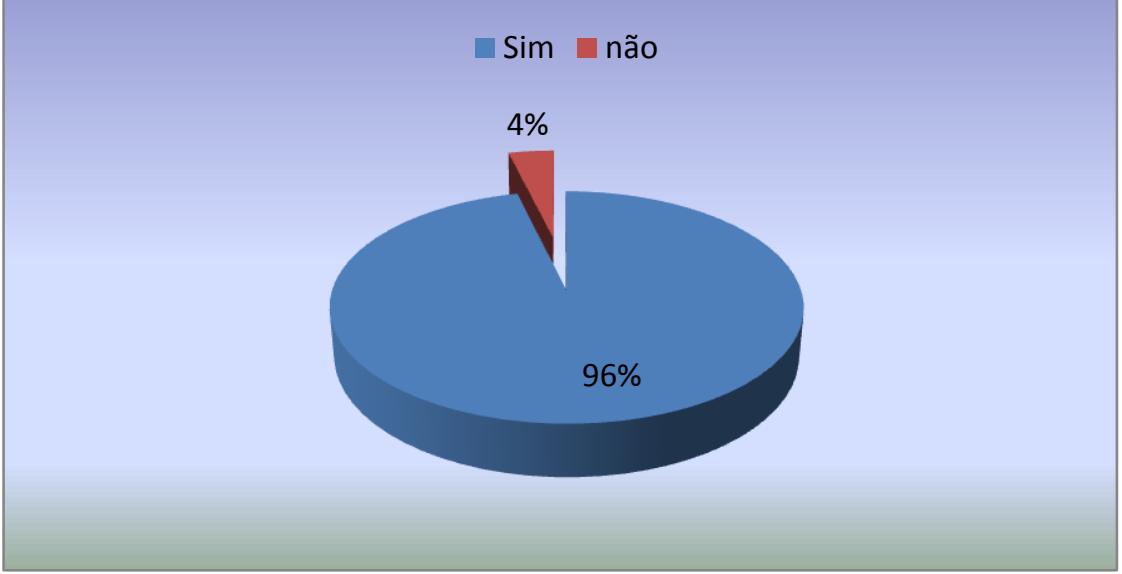

Gráfico 16. Porcentagem dos entrevistados da disciplina TF/0123 que estão fazendo pela primeira vez a disciplina. Amostra composta por 53 respostas.

Para a tabulação dos dados gerados pelas questões seguintes, criamos uma condição no banco de dados ${ }^{44}$ para que, ao gerar o relatório, fossem considerados apenas os dados dos entrevistados que estavam cursando pela primeira vez o $2^{\circ}$ ano do CBio/USP. Portanto, esta pergunta nos permitiu separar os ingressantes do CBio/USP/2006 dos outros estudantes que estavam cursando a Disciplina TF/0123 por motivos de Mestrado, Dependência ou como Alunos Especiais.

Q3q2: Ao longo deste período em que você se encontra na USP, cursando Ciências Biológicas, você já teve alguma disciplina que abordou os conceitos de flor e fruto? (Se 'sim', indique na frente $\mathrm{a}(\mathrm{s})$ disciplina(s).)

\footnotetext{
${ }^{44}$ Essa ferramenta é oferecida pelo próprio programa Access ${ }^{\circledR} 2007$.
} 


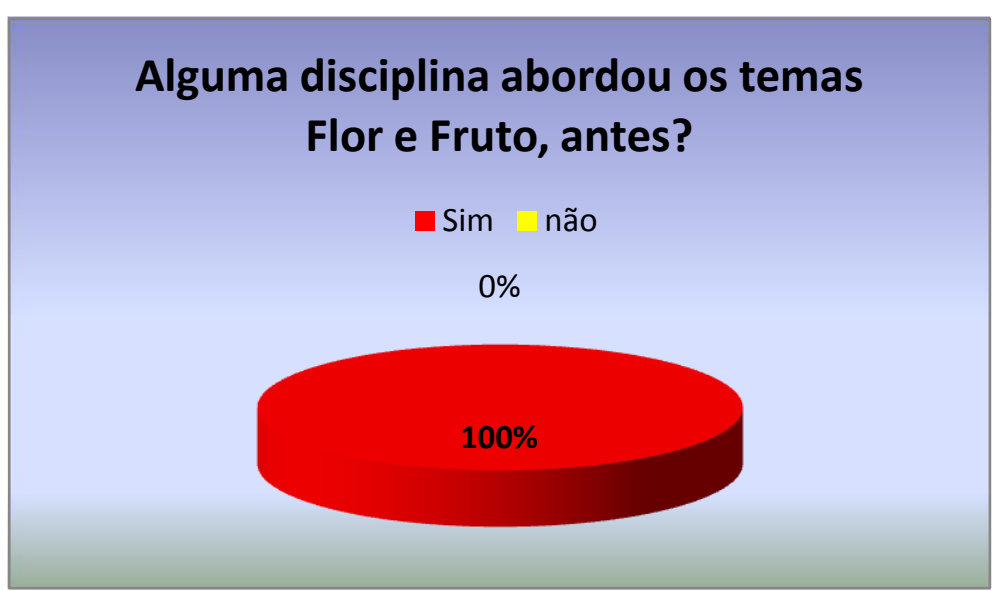

Gráfico 17. Porcentagem dos entrevistados que afirmam que os conceitos de flor e de fruto foram abordados em disciplinas anteriores à disciplina TF/0123. Amostra composta por 51 respostas.

Os entrevistados foram unânimes em afirmar que sim, e, na mesma questão, indicaram as disciplinas que abordaram os temas. Como alguns entrevistados indicaram duas ou mais disciplinas (foram citadas até três disciplinas diferentes por entrevistado), o número de respostas da tab. 13 refere-se ao número de vezes em que a disciplina foi citada no montante das respostas.

Eram esperadas, como indicação, as disciplinas MAPV/0121 e TF/0123, além das disciplinas já apontadas na questão Q2q2 (Gráfico 12; tab. 8). Os resultados obtidos foram tabulados e apresentados na tab. 13.

Tabela13. Disciplinas que abordaram os conceitos de 'flor'e de 'fruto' em 2006/2007 apontadas pelos entrevistados da disciplina TF/0123.

\begin{tabular}{lcc}
\hline \multicolumn{1}{c}{ DISCIPLINA } & Qt & $\%$ \\
\hline Morfologia e Anatomia de Plantas Vasculares & 40 & 52.6 \\
Taxonomia de Fanerógamas & 22 & 29.0 \\
Fauna, Flora e Ambiente & 3 & 4.0 \\
Não citou a disciplina & 11 & 14.4 \\
Total & 76 & 100.0 \\
\hline
\end{tabular}


Como havíamos discutido no item Q2q2, pareceu-nos incomum que a Disciplina TC/0120 tenha abordado os conceitos de 'flor' e de 'fruto'. Nesta segunda vez, com praticamente os mesmo entrevistados, não foi citada a disciplina. Como tivemos onze abstenções nas respostas, não podemos afirmar categoricamente que a Disciplina TC/0120 não tenha abordado os supracitados conceitos. A Disciplina FFA/0410109 se manteve, um indicativo de que a disciplina, em algum momento do curso, abordou o tema, mesmo que em um contexto mais amplo, como já nos referimos anteriormente.

Outro dado relevante é o fato de termos a citação da Disciplina MAPV/0121 apenas 40 vezes ( $78.4 \%$ dos entrevistados). O fato chama a atenção, pois esta disciplina é obrigatória, segundo o Projeto pedagógico do CBio/USP, para que o aluno possa cursar a Disciplina $\mathrm{TC} / 0123^{45}$. Como tivemos 11 (onze) entrevistados que se abstiveram de indicar a(s) disciplina(s) (21.6\% dos entrevistados), os dados constituem um possível indicador de que a disciplina realmente contemplou os conceitos de 'flor' e de 'fruto'.

Q3q9: Você percebe alguma ligação entre a disciplina Taxonomia de Fanerógamas com alguma outra que você já tenha cursado durante a sua formação no curso de Ciências Biológica pela USP? Se 'sim, sempre' ou 'às vezes', qual a ligação?

\footnotetext{
${ }^{45}$ Taxonomia de Fanerógamas. Pré-requisitos para a disciplina. Vide o link: <http://felix.ib.usp.br/Grad3.htm>. Acessado em: 25 jan. 2010.
} 


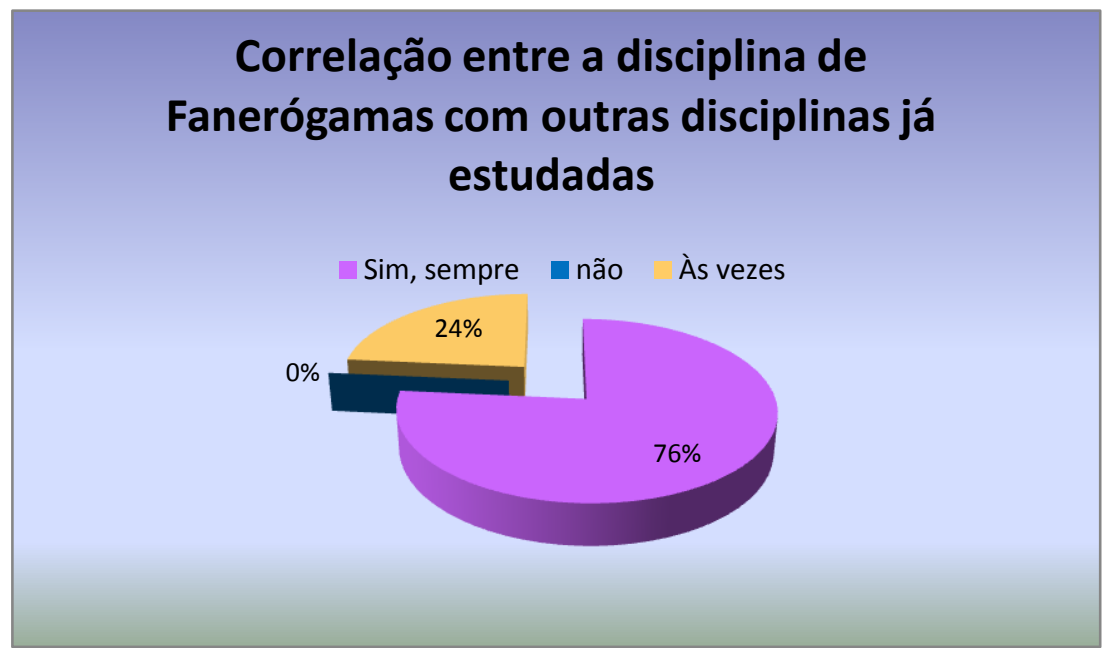

Gráfico 18. Porcentagem dos entrevistados que percebem alguma correlação da disciplina TF/0123 com disciplinas anteriores. Amostra composta por 51 Respostas.

A disciplina de TF/0123 tem como pré-requisito acadêmico que o interessado tenha cursado a Disciplina MAPV/0121 que, dentre outras explicações da sua aplicabilidade na formação profissional do Biólogo, justifica-se por servir de base conceitual para os estudos da Disciplina TF/0123. Confira na tab. 14 a lista das disciplinas que os entrevistados atribuem alguma ligação com a disciplina TF/0123.

Tabela 14. Disciplinas que abordaram os conceitos de 'flor'e de 'fruto' 'sempre' e 'às vezes' em 2006/2007 apontadas pelos entrevistados da disciplina TF/0123.

\begin{tabular}{lcccc}
\hline \multirow{2}{*}{ DISCIPLINAS } & \multicolumn{4}{c}{ RESPOSTAS } \\
\cline { 2 - 5 } & \multicolumn{2}{c}{ SIM, SEMPRE } & \multicolumn{1}{c}{ AS VEZES } \\
\cline { 2 - 6 } & Qt. & $\%$ & Qt. & \% \\
\hline BIB 0121 - MORFOLOGIA E ANATOMIA DE PLANTAS VASCULARES & 25 & 62.5 & 5 & 45.4 \\
041.0107 - PRINCÍPIOS DE SISTEMÁTICA E BIOGEOGRAFIA & 9 & 22.5 & 1 & 9.1 \\
BIE 0210 - ECOLOGIA & 0 & 0.0 & 1 & 9.1 \\
BIO 0112 - PROCESSOS EVOLUTIVOS & 0 & 0.0 & 1 & 9.1 \\
VÁRIAS DISCIPLINAS JÁ ESTUDADAS, MAS SEM ESPECIFICAÇÃO & 3 & 7.5 & 1 & 9.1 \\
NÃO RESPONDEU / RESPOSTA EVASIVA & 3 & 7.5 & 2 & 18.1 \\
TOTAL & 40 & 100 & 11 & 100 \\
\hline
\end{tabular}

Analisando os dados presentes na tab. 14, podemos inferir que alguns entrevistados (41.2\%) ainda apresentam dificuldades em perceber que há uma interligação entre as 
disciplinas, em especial, a disciplina MAPV/0121 com a disciplina TF/0123. A disciplina MAPV/0121 é a base teórica e epistemológica que apoiará este sujeito da aprendizagem na compreensão e no desenvolvimento de todas as atividades práticas. Mesmo dentre os entrevistados que afirmaram que "sim, sempre", as respostas também não são claras, pois somente citam o nome da disciplina, ou melhor, parte dela, como, por exemplo, os entrevistados (TF/002/2007; TF/005/2007; TF/017/2007; TF/018/2007) ${ }^{46}$, que dizem apenas "Vasculares ou vasculares", indicando a Disciplina MAPV/0121. Outros já conseguem estabelecer algum tipo de relação entre as disciplinas, principalmente de "aplicação/uso", quando, por exemplo, no caso do entrevistado (TF/010/2007) que afirma: “usei conceitos aprendidos em vasculares" (negrito meu); ou, então, como no caso do entrevistado (TF/006/2007), que também faz o mesmo tipo de afirmação ao dizer que "MAPV [Morfologia e Anatomia de Vasculares]: todos os conceitos aprendidos nesta matéria são usadas em Fanerógamas”. (negrito meus).

O próprio Programa Curricular também institui que os sujeitos da aprendizagem devem cursar algumas disciplinas de cunho obrigatório, entre elas: Princípios de Sistemática e Biogeografia (PSG/041.0107), FFA/0410109, entre outras; ambas são disciplinas do $1^{\circ}$ Semestre do CBio/USP. Neste sentido, as aulas de PSG/041.0107, cujo principal objetivo é “proporcionar aos alunos os fundamentos de sistemática e biogeografia, além de noções básicas de taxonomia, classificação e nomenclatura biológica" ${ }^{\text {47 }}$, também são essenciais para que o aluno da Disciplina TF/0123 consiga entender as relações filogenéticas existentes entre as Classes e Famílias dos dois grandes grupos de plantas estudados - gimnospermas e angiospermas. Neste caso, a dificuldade dos sujeitos da aprendizagem em perceber a relação entre PSG/041.0107 e TF/0123 é ainda maior, pois o número de vezes em que ela é apontada

\footnotetext{
${ }^{46}$ Esse termo é muito comum entre os estudantes.

${ }^{47}$ Vide descrição da disciplina em: <http://felix.ib.usp.br/Grad3.htm>. Acessado em: 25 jan. 2010.
} 
está bem abaixo da MAPV/0121, como podemos observar na tab. 14. Fora isso, também são citadas de forma vaga, sem uma explicação ou algo que nos permita inferir sobre a(s) possível(is) “correlação(ões)” entre as disciplinas supracitadas acima. Além das já apontadas por nós, outras são citadas de forma genérica, sem especificação, como, por exemplo, do entrevistado (TF/023/2007) que afirma: "com todas as disciplinas de botânica"; ou do entrevistado (TF/009/2007) que afirma: “forte ligação com matérias de botânica e indireta com diversas outras disciplinas" (negrito meu).

\subsubsection{As relações dos estudantes de $T F / 0123$ com a sua formação profissional}

Q3q3: Qual o número de créditos que você cursa por semana?

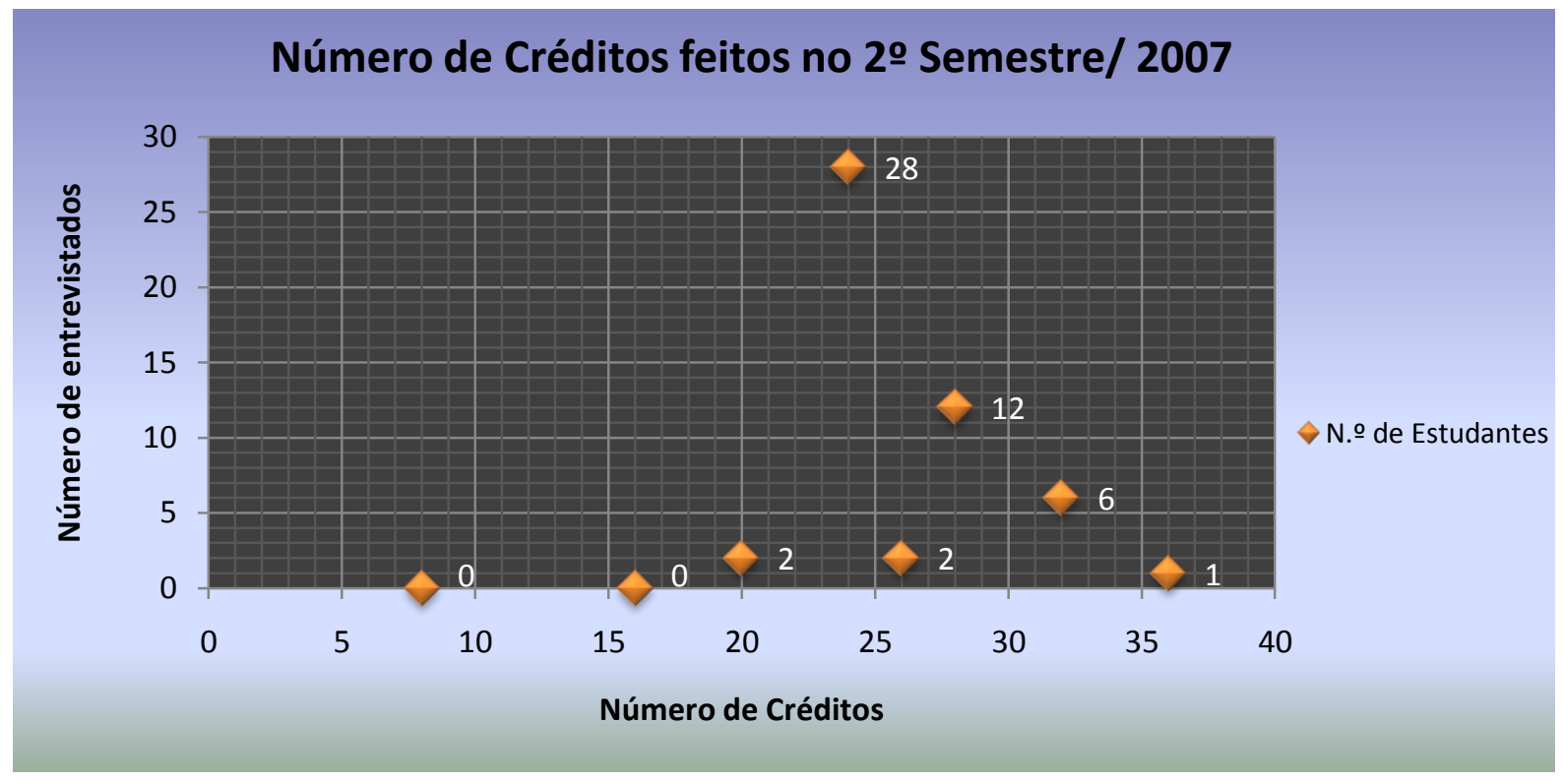

Gráfico 19. Relação entre o $n^{\circ}$ de estudantes e o n. ${ }^{\circ}$ de créditos feitos no $2^{\circ}$ semestre/2007. Amostra composta por 51 entrevistados. 
Dentre os inscritos na Disciplina TF/0123, podemos perceber que uma boa porcentagem dos mesmos $(59.0 \%)$ cursava 24 créditos no semestre, o que equivale à 360 horas de estudos, em disciplinas diversas. Em parte, este número está condicionado ao total de créditos que os ingressantes do CBio/USP/2006 deveriam cumprir no Núcleo Básico Comum, um total de 3.090 horas (199 créditos), com o tempo mínimo de 7 semestres e o máximo de 12 semestres, sendo o "tempo ideal" de duração do curso em 8 semestres. Em 2007, surgiu um novo programa e houve alterações para os ingressantes a partir de então. Os outros ingressantes antes de 2007 continuaram com o programa anterior.

Chauí (2003, p. 11) comenta que "a própria competição do mercado de trabalho exige que o candidato a emprego apresente um currículo com mais créditos do que outros”. Provavelmente, por isso, alguns dos entrevistados estivessem cursando trinta e dois e/ou trinta e seis créditos justamente pensando na sua formação profissional e na sua atuação futura no mercado de trabalho.

Q3q4: Qual a sua motivação para frequentar as aulas?

Neste caso, as respostas obtidas foram tabuladas (tab. 15) segundo os princípios da análise de conteúdo de Bardin(2008) e de Caldeiras (2000) (vide capítulo 3 - quadro 6).

Tabela 15. Motivações apontadas pelos entrevistados da disciplina TF/0123 para frequentar as aulas

\begin{tabular}{llc}
\hline Categoria & Item & N. ${ }^{\circ}$ de ocorrências \\
\hline \multirow{3}{*}{ Profunda } & Aprender por prazer & 26 \\
& Curso (biologia) & 12 \\
& Aprender através das aulas & 6 \\
& Temas abordados & 6
\end{tabular}

Continua 
Conclusão

Tabela 15. Motivações apontadas pelos entrevistados da disciplina TF/0123 para frequentar as aulas

\begin{tabular}{llc}
\hline Categoria & Item & N. ${ }^{o}$ de ocorrências \\
\hline \multirow{2}{*}{ Profunda } & Aplicação na prática & 2 \\
& Autodidata & 2 \\
& Aulas estimulantes & 2 \\
& Cultura & 2 \\
Automotivação & 1 \\
Seguir a carreira científica & 12 \\
Estratégica & Conclusão do curso & 6 \\
& Conteúdo para as provas & 4 \\
& Exercer a profissão (biólogo) & 2 \\
Superficial & Aulas práticas & 2 \\
Desorganizada & Diálogo (troca de informações) & 1 \\
& Incrementar a formação & 14 \\
& Professor & 1 \\
& Autoestima & 2
\end{tabular}

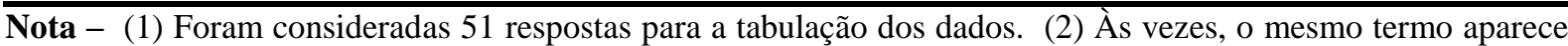
mais de uma vez na resposta do entrevistado.

Segundo Nérici (1983, p. 75), a "motivação é o estado interior, emocional, que desperta o interesse ou inclinação do indivíduo para algo. Interesse, por sua vez, é inclinação que uma pessoa sente, especialmente, por alguma via material ou espiritual”.

Nérici (ibid., p. 76-77) afirma que existem quatro tipos de motivações: "intrínsecas", “extrínsecas”, “física” e "psicológica”. A motivação intrínseca é àquela inerente ao sujeito, portanto, depende única e exclusivamente do próprio estudante para que o mesmo execute qualquer atividade. As motivações extrínsecas são acionadas por fatores externos ao sujeito, sem que haja nenhuma relação direta do estudante com o conteúdo ou com a matéria lecionada. No caso da motivação física, o sujeito sofre desde agressões físicas até privações de coisas que para ele representem algo de valor. Finalmente, entre as motivações psicológicas, se encotram aquelas que provocam algum tipo de coação do sujeito. Entre as respostas destacadas, podemos perceber que há um número de ocorrências considerável que 
apontam que os entrevistados demonstram uma motivação intrínseca, ao afirmarem que estudam por prazer, ou que buscaram uma profissão pela qual se identificam. Por outro lado, os itens que se sobressaem são as motivações extrínsecas, praticamente o dobro das motivações intrínsecas.

Para Becher (2001, p. 44), ao estabelecer a relação entre os sujeitos acadêmicos e suas áreas de atuação, defende a ideia de que

[...] pertencer a uma comunidade de uma disciplina implica um sentimento de identidade e de compromisso pessoal, uma "forma de estar no mundo", adotar "um marco cultural que define uma grande parte da própria vida" (GEERTZ, 1983). Para um futuro membro de uma comunidade acadêmica, o processo de construção dessa identidade e desse compromisso pode começar quando o estudante é da graduação, mas se desenvolverá em sua máxima intensidade na etapa da pós-graduação, para culminar no doutorado ou, para os poucos eleitos, na primeira oferta de emprego como docente universitário.

Então, no caso em que os sujeitos da aprendizagem defendem a ideia de que estudam por prazer, ou que se reconhecem dentro do curso de Biologia, nada mais estão fazendo do que criar uma identidade acadêmica com o curso escolhido. Essa "identidade" procede das suas motivações intrínsecas, geralmente. Outras vezes, pode proceder também de motivações extrínsecas, como, por exemplo, esperança de obter recompensas, como, por exemplo, desenvolver alguma pesquisa e ser reconhecido por isso algum dia. São inúmeras as possibilidades.

Q3q5: Você realiza leituras sobre os assuntos estudados além das indicadas pelo professor? 


\section{Realiza leituras extras}

Sim não às vezes

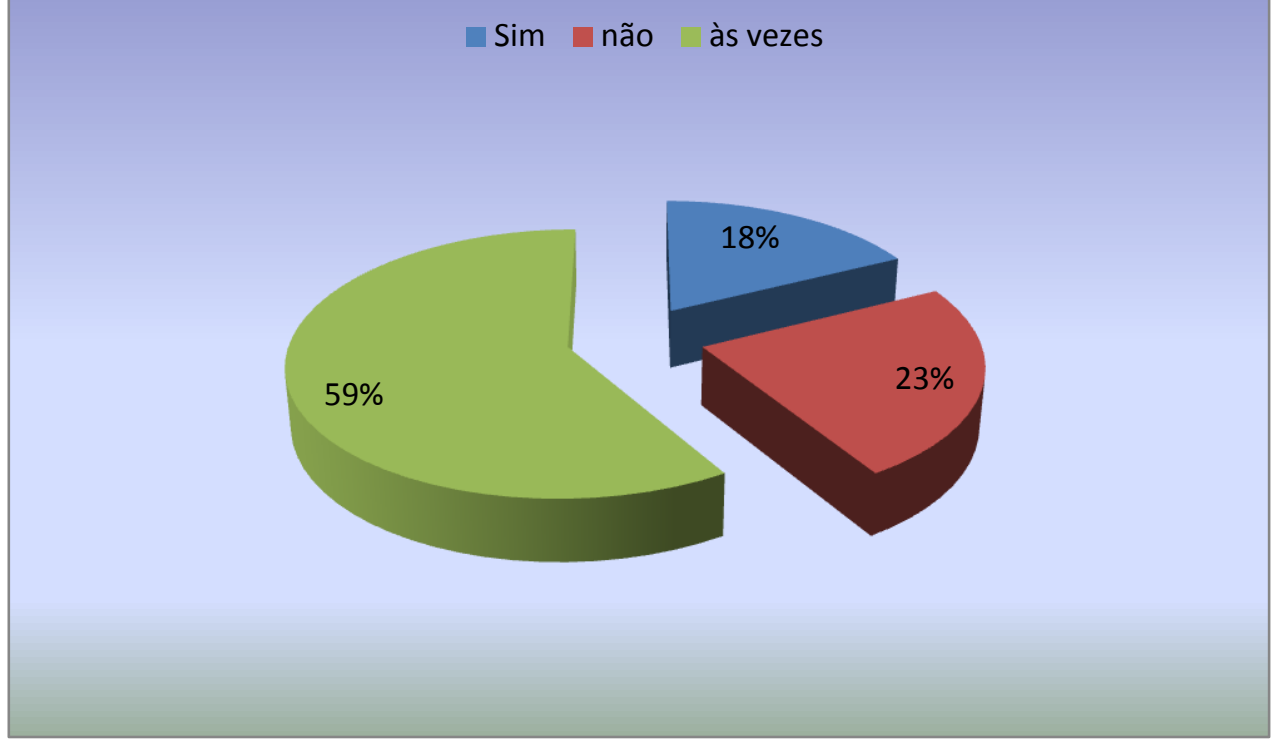

Gráfico 20. Porcentagem dos entrevistados da disciplina TF/0123 que fazem leituras extras além do material fornecido durante o curso. Amostra composta por 51 respostas.

Apesar dos entrevistados afirmarem que gostam de aprender pelo prazer que isso lhes proporciona (tab. 15), o mesmo não se dá no gráfico 20, onde temos que apenas 9 entrevistados (18.0\%) buscam sempre informações extras após as aulas. Nos próximos dados, perceberemos melhor quais as possíveis "motivações" que levam os entrevistados a fazerem uso de outros materiais de estudo além dos já fornecidos pelo curso de CBio/USP.

Q3q6: Você realiza pesquisas na internet sobre os temas abordados em sala de aula? $\underline{\text { Se 'sim, sempre' ou 'às vezes', em que momento dos seus estudos? }}$ 


\section{Frequência do uso da Internet}

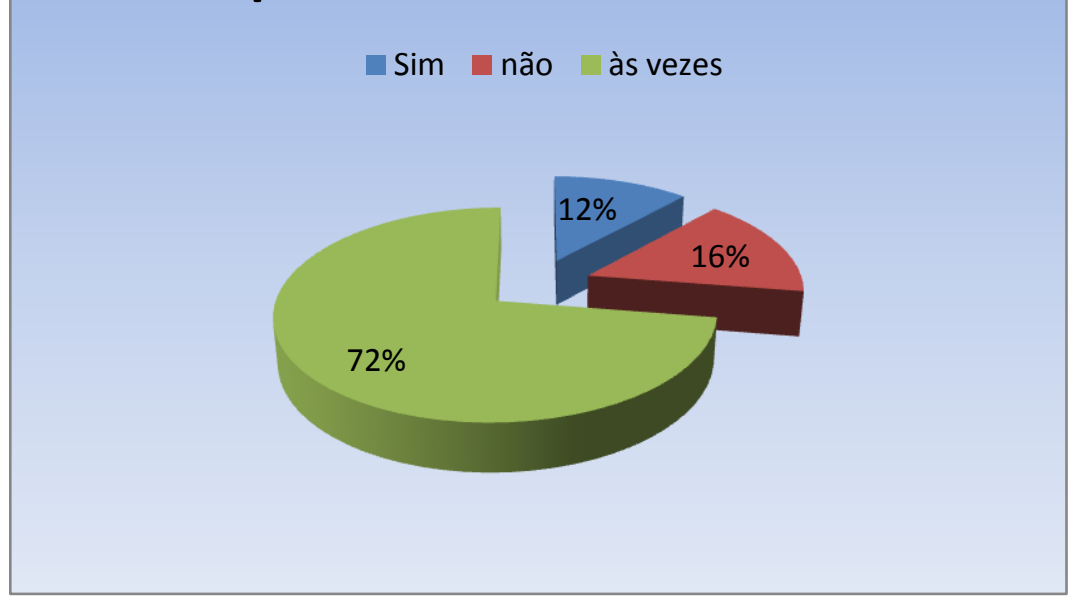

Gráfico 21. Frequência dos entrevistados da disciplina TF/0123 que fazem uso da Internet para complemento dos estudos. Amostra composta por 51 respostas.

A resposta mais frequente foi ‘Às vezes' (72\%), como podemos perceber no gráfico 21. Mas, os motivos desse fluxo de pesquisa intermitente aparecem nas respostas apresentadas nas tabelas. 16 e 17.

Tabela 16. Categorização do uso da Internet pelos entrevistados da disciplina TF/0123 - opção 'Sim, sempre'.

\begin{tabular}{llc}
\hline Categoria & Item & $\mathrm{N}^{\circ}$ de ocorrência(s) \\
\hline \multirow{2}{*}{ Profunda } & Comparar conteúdos & 4 \\
& Estudo virtual & 2 \\
\hline \multirow{2}{*}{ Estratégica } & Estudar para as provas, exclusivamente & 2 \\
& Uso cotidiano & 2
\end{tabular}

$\overline{\text { Nota - (1) Foram consideradas } 6 \text { respostas para a tabulação dos dados. (2) Às vezes, o mesmo termo aparece }}$ mais de uma vez na resposta do entrevistado.

Na tab. 17, os itens mais citados, são justemente as motivações extrínsecas, como, por exemplo, trabalhos de pesquisa, avaliações ou a não compreensão do assunto estudado em classe, entre outros. 
Tabela 17. Categorização do uso da Internet pelos entrevistados da disciplina TF/0123 - opção 'Às vezes'.

\begin{tabular}{|c|c|c|}
\hline Categoria & Item & $\mathrm{N}^{\mathrm{o}}$ de ocorrência(s) \\
\hline \multirow{3}{*}{ Superficial } & Realizar trabalhos (pesquisa) & 12 \\
\hline & Quando dispõe de tempo & 6 \\
\hline & Uso aleatório & 1 \\
\hline \multirow{6}{*}{ Estratégica } & Estudar para as provas, exclusivamente & 12 \\
\hline & Não compreendeu a aula & 6 \\
\hline & Busca de conteúdos, informações & 4 \\
\hline & Dúvidas & 4 \\
\hline & Fotos de plantas & 2 \\
\hline & Estudar para a disciplina Taxonomia de Fanerógamas & 2 \\
\hline Profunda & Interesse pessoal por determinado assunto & 10 \\
\hline
\end{tabular}

Nota - (1) Foram consideradas 37 respostas para a tabulação dos dados. (2) Às vezes, o mesmo termo aparece mais de uma vez na resposta do entrevistado.

Q3q7: Você realiza pesquisas na biblioteca sobre os temas abordados em sala de aula? Se 'sim, sempre' ou 'às vezes', em que momento dos seus estudos?

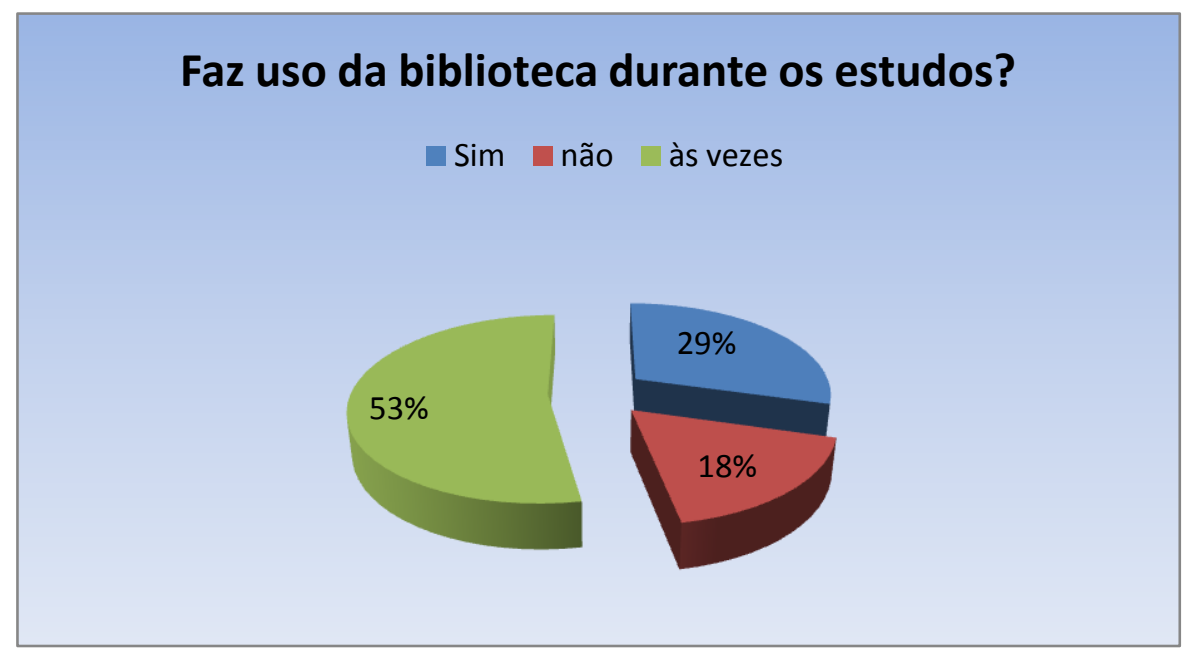

Gráfico 22. Frequência do uso da biblioteca para estudos. Amostra composta por 51 respostas. 
Aqui temos outros detalhes interessantes sobre o uso de espaços não formais para a aprendizagem. Neste caso, estamos falando da biblioteca. A biblioteca do IB - USP disponibiliza aos frequentadores, além do acervo atualizado através das revistas, livros e períodos disponíveis em duas versões - impressa e virtual -, além de dois ambientes de estudos: um aberto para a organização de grupos e outro, onde o silêncio absoluto deve ser mantido. Mesmo assim, percebemos que apenas um terço dos entrevistos fazem uso constante. Uma boa parcela apenas às vezes (53.0\%) (gráfico 22). Os motivos aparecem nas tabelas 18 e 19 , logo abaixo.

Tabela 18. Categorização do uso da biblioteca pelos entrevistados da disciplina TF/0123 - opção 'Sim, sempre'.

\begin{tabular}{llc}
\hline Categoria & Item & $\mathrm{N}^{\mathrm{o}}$ de ocorrência(s) \\
\hline \multirow{3}{*}{ Profunda } & Disponibilidade de tempo (sempre) & 8 \\
& Estudar & 6 \\
& Busca de informações complementares & 4 \\
\hline \multirow{2}{*}{ Estratégica } & Realizar trabalhos (pesquisas) & 4 \\
& Estudar para as provas, exclusivamente & 4
\end{tabular}

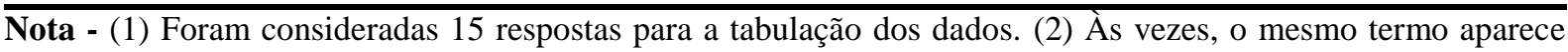
mais de uma vez na resposta do entrevistado.

Tabela 19. Categorização do uso da biblioteca pelos entrevistados da disciplina TF/0123- opção ‘Às vezes’.

\begin{tabular}{llc}
\hline Categoria & Item & $\mathrm{N}^{\mathrm{o}}$ de ocorrência(s) \\
\hline Superficial & Realizar os trabalhos (pesquisas) & 16 \\
& Estudar para as provas, exclusivamente & 12 \\
& Professor & 1 \\
\hline Estratégica & Esclarecer dúvidas & 6 \\
& Entender o conteúdo das aulas & 6 \\
\hline Profunda & Busca de informações complementares & 4 \\
\hline & Disponibilidade de tempo & 2 \\
\hline
\end{tabular}

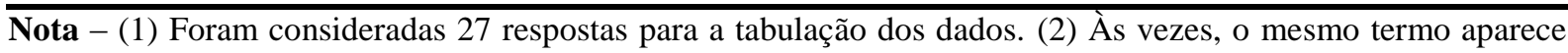
mais de uma vez na resposta do entrevistado. 
Ao atentarmos para os itens que aparecem nas tabelas 18 e 19, podemos perceber que as motivações que levam os entrevistados a procurar este espaço de estudos alternativo, está vinculado diretamente às motivações extrínsecas, como, por exemplo, realizar trabalhos de pesquisa, estudar para as provas, esclarecer dúvidas (provavelmente, com outros sujeitos da aprendizagem do curso - prática comum observável neste local), entre outras. Mesmo dentre aqueles que procuram fazer o uso constante da biblioteca, também aparecem motivações desencadeadas por fatores externos ao sujeito, como, por exemplo, estudar para as provas.

Q3q8: Você já desenvolveu algum tipo de estágio em laboratório e/ou pesquisa de $\underline{\text { campo, onde o seu tema principal foi a pesquisa com plantas vasculares? (Se 'sim', indique na }}$ frente o estágio e o seu orientador)

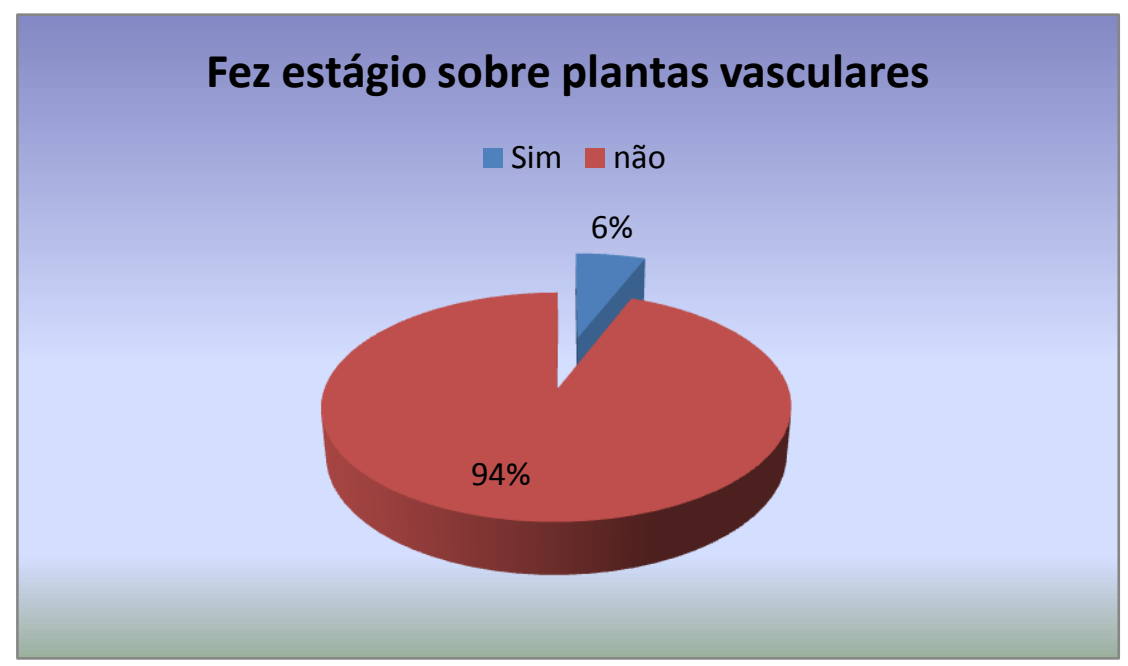

Gráfico 23. Porcentagem dos entrevistados que fizeram estágio, com enfoque em plantas superiores. Amostra composta por 51 respostas. 
Apenas três entrevistados afirmaram que fizeram estágio, mas somente um indicou o local e o orientador responsável pelo Estágio - Anatomia Vegetal, com o Prof. Dr. Gregório Cardoso Tápias Ceccantini. Como no semestre anterior, a mesma pergunta foi realizada (Q2q5), onde apenas um entrevistado havia feito o estágio com em Anatomia Vegetal, com o Prof. Dr. Ceccantini.

Após dois anos de estudos na Universidade, somente $6.0 \%$ se motivaram a fazer estágio (relacionado à área da Botânica). Pautado nas considerações de Masetto (2003) sobre o enfoque da docência no ensino e não na aprendizagem, poderíamos considerar a possibilidade dos entrevistados estarem sofrendo a ação de um "currículo oculto", sugestionando aos sujeitos da aprendizagem que somente poderão participar de determinado estágio no laboratório aqueles que apresentarem como requisito prévio conhecimentos acadêmicos, ou um número "x" de créditos, para exercer determinadas funções e realizar determinadas pesquisas onde se "exige" um cabedal de conhecimentos mais específicos, conhecimentos estes que se adquirem ao longo da imersão do estudante na Universidade. Outra possível causa talvez seja o próprio entrevistado que não consegue conciliar os estudos obrigatórios (créditos obrigatórios) com outras atividades. Fica essa questão em aberto, para uma próxima pesquisa.

\section{Q3Q10: Por que você estuda?}

Complementando a questão $\mathrm{Q} 3 \mathrm{q} 4$, relacionada aos itens motivacionais, aparecem termos semelhantes na tabela 20, dentre eles: o prazer pelos estudos, as avaliações, a aprovação. 
Charlot (2003), analisando a relação dos estudantes com o ensino, afirma que para os “intelectuais" estudar faz parte da sua "natureza", ou seja, constitui a sua condição humana, e não conseguem parar de estudar. Geralmente encontram-se na classe média e raramente na classe popular. Já no meio popular, o que se observa são sujeitos da aprendizagem que estudam em busca de uma conquista permanente do saber e da boa nota; sendo que, entre estes, observam-se aqueles que estudam não para aprender, mas para passar para a série seguinte; em seguida, novamente para a série seguinte, até obter um diploma, um bom emprego, uma vida "normal” ou mesmo seguir um "belo caminho". Também comenta que há estudantes que se engajam na "conquista voluntarista do sucesso escolar" e, graças a esse sucesso, encontram sentido e prazer no estudar, além de um "futuro melhor". O "sucesso", então, está diretamente relacionado ao fato do estudante ter ou não ter uma atividade intelectual, ou seja, "uma atividade eficaz que lhe possibilite apropriar-se dos saberes e construir competência cognitivas" (p. 29). Assim sendo, Charlot acredita que, o fracasso ou o sucesso escolar do estudante, não está ligado ao fato dele pertencer ou não a uma classe popular, mas sim ao fato do sujeito da aprendizagem estudar ou não estudar de maneira eficaz.

Para que o sujeito da aprendizagem desenvolva essa atividade intelectual de modo eficaz, faz-se-á necessário que o mesmo encontre motivação, desejo, ou melhor dizendo, que o estudante se mobilize intelectualmente. Para Charlot (2003, p. 29-31) essa mobilização somente acontece quando se apresentam duas condições:

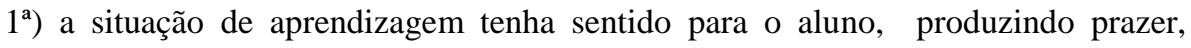
correspondendo a um desejo do mesmo; $2^{\mathrm{a}}$ ) que essa mobilização intelecutal induza a uma atividade intelectual eficaz, ou seja, faça com que o aluno consiga diferenciar a normatividade da normatização social, aplicando essas normas em seu cotidiano.

(CHARLOT, 2003, p. 29-31) 
Tabela 20. Categorização das causas pelas quais os entrevistados da disciplina TF/0123 estudam

\begin{tabular}{|c|c|c|}
\hline Categoria & Item & $\mathrm{N}^{\mathrm{o}}$ de ocorrência(s) \\
\hline \multirow{6}{*}{ Profunda } & Gosta do curso & 16 \\
\hline & Aumentar o conhecimento & 12 \\
\hline & Para aprender & 12 \\
\hline & Criar links com outras disciplinas & 2 \\
\hline & Por prazer & 2 \\
\hline & "sedimentar" conteúdo(s) & 1 \\
\hline \multirow{2}{*}{ Estratégica } & Formar-se em biologia & 12 \\
\hline & Ter boas notas & 8 \\
\hline \multirow{4}{*}{ Superficial } & Por causa das avaliações & 10 \\
\hline & Quando o conteúdo lhe interessa & 8 \\
\hline & Curiosidade & 4 \\
\hline & Ser aprovado(a) & 4 \\
\hline \multirow{4}{*}{ Desorganizada } & Melhorar a formação & 4 \\
\hline & "status" social & 2 \\
\hline & Necessidade & 1 \\
\hline & Não respondeu & 2 \\
\hline
\end{tabular}

Nota - (1) Foram consideradas 51 respostas para a tabulação dos dados. (2) Às vezes, o mesmo termo aparece mais de uma vez na resposta do entrevistado.

Nas tabelas de 15 à 20 é possível perceber em muitas das "falas" levantadas, "motivações" voltadas para questões de prazer intelectual, mas, também questões relacionadas apenas ao aprender para obter-se um diploma ou uma ascensão social. Charlot (2003, p. 28) denomina esse processo de busca pela ascensão social de "continuidade na heterogeneidade (ou de heterogeneidade na continuidade)" desencadeado pelos próprios pais na busca de uma situação de vida melhor, incultindo nos filhos a necessidade desta busca, mesmo que isso venha ocasionar o rompimento das relações familiares. Para tanto, os estudantes buscam estratégias de aprendizagem, para suprir as suas prioridades, estabelecendo relações superficiais a relações profundas com a sua formação profissional (MARTON, 1983; 1984). 
Além do estudante, há outros fatores que podem interferir na relação do sujeito com a aprendizagem: o lar, a sociedade, o professor e a universidade (NÉRICI, 1983; CHARLOT, 2003; FREIRE, 1988; 2002). Esses fatores estão ligados a "motivações negativas" ou a relações de domínio, como, por exemplo, abandono do sujeito por parte da família, excesso de estímulos despersivos e destimulantes, falta de preparo pedagógico do professor, aulas desistimulantes, descaso para com os estudantes, instalações inadequadas, programa curricular desajustado, entre tantos outros.

Essas relações dos sujeitos da aprendizagem para com a sua própria formação também estão voltadas para o tipo de currículo fornecido pela Universidade, ou seja, um currículo voltado para o ensino e não para a aprendizagem.

\subsubsection{As relações dos sujeitos da aprendizagem com as metologias de ensino empregradas na sua formação}

Até agora, as nossas observações foram centradas apenas nos "sujeitos da aprendizagem". Mas, o processo de aprendizagem não ocorre unilateralmente, e sim em uma via de mão dupla, ou seja, através do diálogo entre o(s) sujeito(s) do conhecimento e o(s) sujeito(s) da aprendizagem (LEVINAS, 1998; FREIRE 1988; 2002; MASETTO, 2003; KRASILCHIK，2004; GOROW，1977; BORDENAVE，PEREIRA，2007; VIGOTSKY, 2004).

Pensando neste aspecto, elaboramos as questões Q3q11 e Q3q14, para verificarmos como os sujeitos do conhecimento abordam os conteúdos que ensinam e também quais os instrumentos de avaliação que fazem uso para verificar o aprendizado dos seus educandos. 
Para não perdermos a linha de raciocínio, faremos a análise da questão Q3q14, antes das questões Q3q12 e Q3q13.

Q3Q11: Durante a Disciplina de Taxonomia de Fanerógamas, qual(is) modalidade(s) didática(s) o(s) professor(es) abordou(aram) durante as suas aulas? Leve em consideração os números 1 -sempre, 2 - nunca, 3 - às vezes, para indicar a freqüência que você percebeu o $\underline{\text { uso desses recursos durante a sua formação. }}$

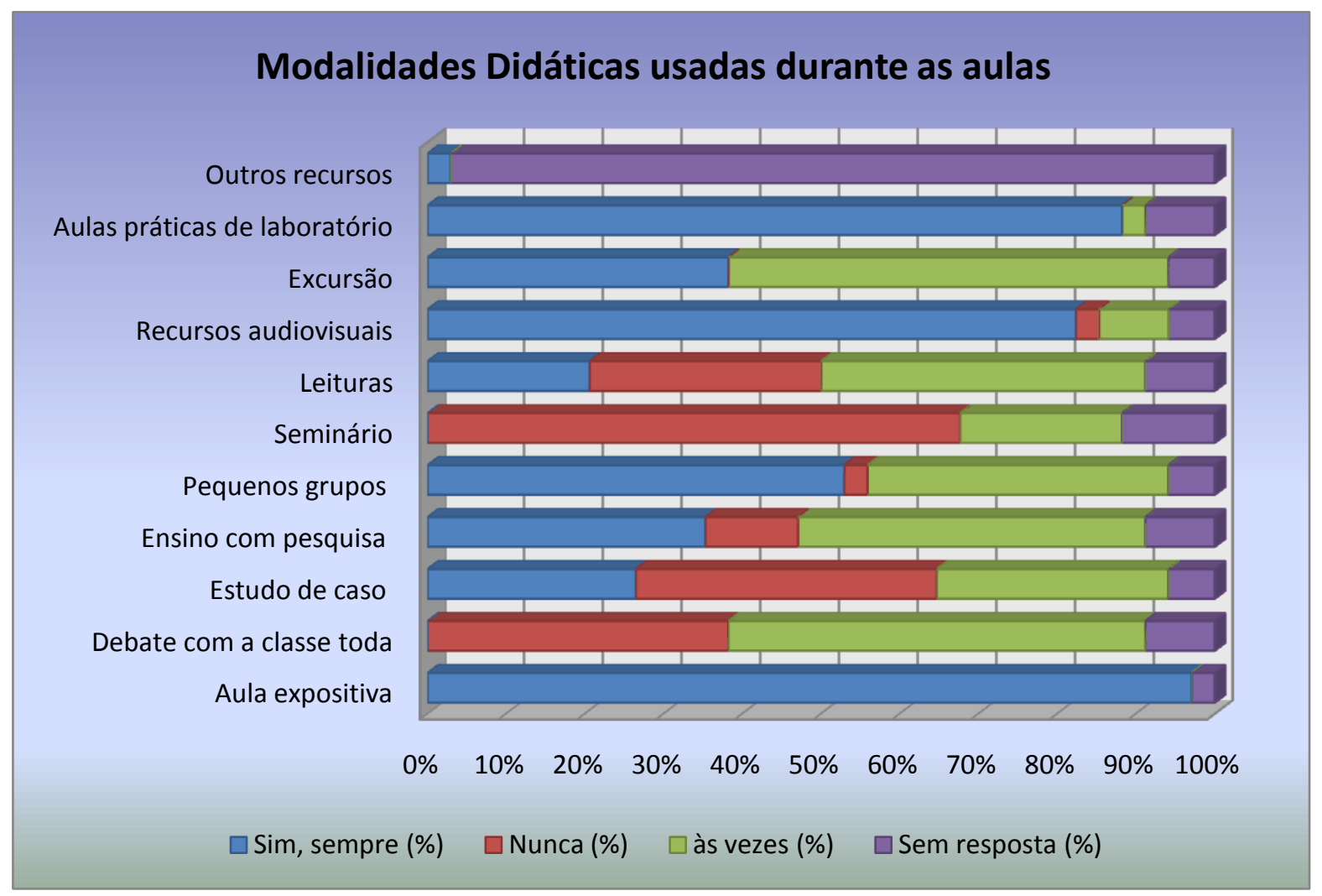

Gráfico 24. Porcentagem de diversos recursos didáticos usados ou não em aula. Amostra composta por 51 respostas. 
As aulas, segundo o gráfico 24, restringem-se, na sua grande maioria, a três aspectos: aulas expositivas, uso de recursos audiovisuais e aulas práticas de laboratório. As outras atividades que aparecem em menor porcentagem, aparentemente, são instituidas em momentos pontuais e não são constantes no processo de ensino-aprendizagem. Em outras modalidades, apenas um entrevistado citou como modalidade didática o plantão de dúvidas com os monitores (estudantes de graduação ou de pós-graduação que já fizeram a disciplina e que acessoram os sujeitos do conhecimento e os sujeitos da aprendizagem nas atividades, em especial, nas aulas de laboratório).

Em relação ao ensino com pesquisa, apesar de não se encontrar entre os mais citados, é um dos itens da avaliação da disciplina, neste caso, como um trabalho de final de curso, que consiste na análise de morfologia vegetativa e floral para identificação de famílias e para estudos filogenéticos, desenvolvido em grupos, onde os sujeitos da aprendizagem deveriam escolher dez (10) espécies de plantas pertencente às angiospermas, coletá-las e classificá-las, utilizando-se para isso, dos instrumentos disponíveis em laboratório e também das técnicas exemplificadas em aula.

Krasilchik (2004, p. 58), comenta que os professores de biologia tendem a ocupar $85 \%$ da duração das aulas com as suas preleções sobre o tema abordado em classe. Os $15 \%$ restantes são preenchidos por períodos de confusão e silêncio e pela fala dos estudantes que na maior parte das vezes consiste em pedidos de esclarecimento sobre as tarefas que devem executar. A autora comenta que isso acaba dificultando aos professores saberem o que os seus educandos falam ou pensam sobre os temas abordados em aula. A Krasilchik (2004) sugere mudanças na metodologia empregada em aula, procurando favorecer o diálogo entre o professor e os educandos. Essa implica tanto no tipo de questionamento que o professor desenvolve em sala de aula, como também na sua concepção sobre o compartilhamento do "poder" entre o sujeito do conhecimento e os sujeitos da aprendizagem. 
Godoy (1989), em sua tese, buscou trabalhar a percepção que os estudantes universitários têm em relação ao ambiente real e/ou preferido através de instrumentos de altainferência. Estas medidas estão baseadas nas experiências dos sujeitos da aprendizagem em muitas situações de ensino, levando-se em consideração o cojunto de julgamento de todos os estudantes da classe. Além disso, como defende a autora, as opiniões dos sujeitos da aprendizagem são, de certa forma, determinantes de seu comportamento, por isso oferecem informação mais real e talvez mais importante do que comportamentos observados por um elemento externo, ou inferidos pelo pesquisador. Assim como Godoy (1989), também compartilhamos da ideia de que a visão do sujeito da aprendizagem sobre o ambiente da sala de aula é fundamental para aqueles que nela atuam como sujeitos do conhecimento, regulares ou em esquemas de treinamento didático e também para administradores escolares, pois permite a estes profissionais direcionar as suas aulas para um melhor aproveitamento por parte dos estudantes dos temas abordados em classe.

Ao desenvolver o tema da sua pesquisa, Godoy afirma que em pesquisas desenvolvidas por Moos na década de setenta, existe a associação entre a percepção que o sujeitos da aprendizagem tem do ambiente da sala de aula e o nível de satisfação sentido pelos próprios professores e estudantes. Os resultados mostram que os estudantes sentem maior satisfação em sala de aula caracterizadas por apresentarem alto grau de desenvolvimento e afiliação, na qual são utilizadas novos métodos de ensino e há clareza nas regras estabelecidas. Em classes desse tipo os estudantes sentem-se mais respeitados como pessoas, trabalham muito visando as recompensas acadêmicas e consideram que seu aprendizado foi maior. Estes resultados sugerem que o ambiente da sala de aula deve ser intelectualmente desafiante para encorajar o sujeito da aprendizagem em termos de aquisição e compreensão ativa do conhecimento, bem como coeso e agradável tendo em vista o interesse e a motivação do estudante (MOOS, 1978; MOOS E MOOS, 1978; apud GODOY, 1989, p. 51-52). 
Para Hunt (1975) o professor deveria, em primeiro lugar, preocupar-se em definir as características individuais dos seus educandos, onde, dentre elas, ele chama a atenção para a que ele considera como a mais importante, denominada como "conceptual level", aqui traduzido por nível conceitual. Segundo Hunt et. al. (1974) o nível conceitual de uma pessoa descreve o seu desenvolvimento em termos de aumento de complexidade nas formas de processar as informações, aumento de responsabilidade e de independência. Assim, estudantes com um baixo nível conceitual, dependentes de um padrão externo e incapazes de gerar seus próprios conceitos, conseguem um melhor desenvolvimento intelectual, em ambientes de sala de aula altamente estruturado. Já o grupo de estudantes situados no outro extremo, de alto nível conceitual, capaz de gerar novos conceitos e sustentar padrões internos, são melhores intelecutalmente em ambientes poucos estruturados e menos afetados pelas variações na organização do ambiente.

Masetto (2003) defende a ideia de que a sala de aula não deve ser um espaço onde apenas o professor fale e o estudante ouça, mas sim um espaço em que ocorra a “interaprendizagem", ou seja, um espaço onde as aulas devem ser permeadas por técnicas de ensino que valorizem a participação dos estudantes, a integração dos grupos e a diversificação das formas de se aprender. Assim sendo, ele sugere e orienta sobre os cuidados e as aplicações de metodologias de ensino que busquem desenvover nos sujeitos da aprendizagem a prática da oralidade, do estudo e da integração entre os grupos. Também comenta que, o professor universitário, ao preparar uma aula expositiva deve tomar cuidado em relação a uma série de medidas, para prepará-la e ministrá-la:

- ter claro o objetivo da aula;

- planejar a sequência em que fará a explanação, para garantir que haja clareza e sequência nas ideias, sem cair em digressões;

- considerar que há limite de tempo, para não cansar os alunos e favorecer a divagação;

- considerar a classe para quem vai se dirigir, escolhendo linguagem, exemplos, etc., de acordo com os alunos; 
- preparar uma notícia de jornal ou revista atual que poderá usar em determinado momento para chamar a atenção dos alunos;

- se for usar slides ou transparências, prepará-los apenas com imagens, tabelas, gráficos ou itens indicativos e nunca com texto longos para serem lidos durante o tempo todo. Quanto a slides, calcular muito bem o número a ser usado: poucos, bem escolhidos, que ajudem na explicação ou permitam debate e discussão. Nunca usar um número excessivo que praticamente substitua a aula expositiva;

- preparar com antecedência os materiais e os recursos necessários para a aula e verificar se, no espaço físico onde a aula será dada, há condições para o uso dos recursos, evitando-se assim a frustração para ambos (alunos e professores). (MASETTO, 2003, p. 98-99)

Em relação a aula expostiva propriamente dita, Masetto (ibid., p. 99 - 100), ainda complementa o assunto, resaltando que o professor deve observar os seguintes pontos:

- deixar bastante claro para os alunos qual é o objetivo daquela aula;

- procurar ganhar a atenção dos alunos de início, mediante a apresentação de um problema, de uma pergunta ou de um desafio;

- considerar o ritmo da classe para tomar notas, refletir sobre o que está ouvindo, fazer perguntas, apresentar os pontos dificeis mais devagar, ou repetindo o mesmo conceito ou ideia sob diferentes formas, e, por vezes, permitir pausas rápidas para uma comunicação entre os próprios alunos;

- dirigir-se pessoalmente aos alunos, pedindo deles um feedback sobre a clareza do que está expondo, olhando-os nos olhos um a um, e para isso locomover-se pela sala, comunicando-se com os alunos;

- utilizar-se livremente de recursos auxiliares à palavra para se fazer entender ou para manter o interesse e a atenção dos alunos;

evitar considerar as distrações dos alunos afronta pessoal ou desrespeito; em vez disso, utilizar esses indícios para reorientar sua própria exposição: é o momento de uma pergunta à classe, oud e se comentar uma notícia de jornal, ou mesmo, de contar uma piada, ou de abrir uma janela para conseguir mais ventilação. Afinal, a aula expositiva exige do aluno uma posição passiva, nem sempre fácil de se manter. (MASETTO, 2003, p. 99-100)

Godoy (1989, p. 215) comenta que os dados levantados por ela demonstram que os estudantes universitários, assim como os de outros graus, valorizam professores que mantêm uma postura de diálogo com os sujeitos da aprendizagem, inclusive para conversas informais e de caráter pessoal. 
Assim, parece-nos importante que o sujeito do conhecimento conheça e saiba utilizar adequadamente um rol mais amplo de estratégias de sala de aula, possibilitanto aos mesmos fazerem alterações e criar metologias próprias e adequadas às suas necessidades e às demandas dos sujeitos da aprendizagem, potencializando o processo de ensino-aprendizagem.

Q3q14: Qual(is) instrumentos de avaliação você foi submetido ao longo da disciplina $\underline{\text { Taxonomia de Fanerógamas. Leve em consideração os números } 1 \text { - sempre, } 2 \text { - nunca, } 3 \text { - às }}$ vezes, para indicar a frequência que você percebeu o uso desses instrumentos durante a sua avaliação.

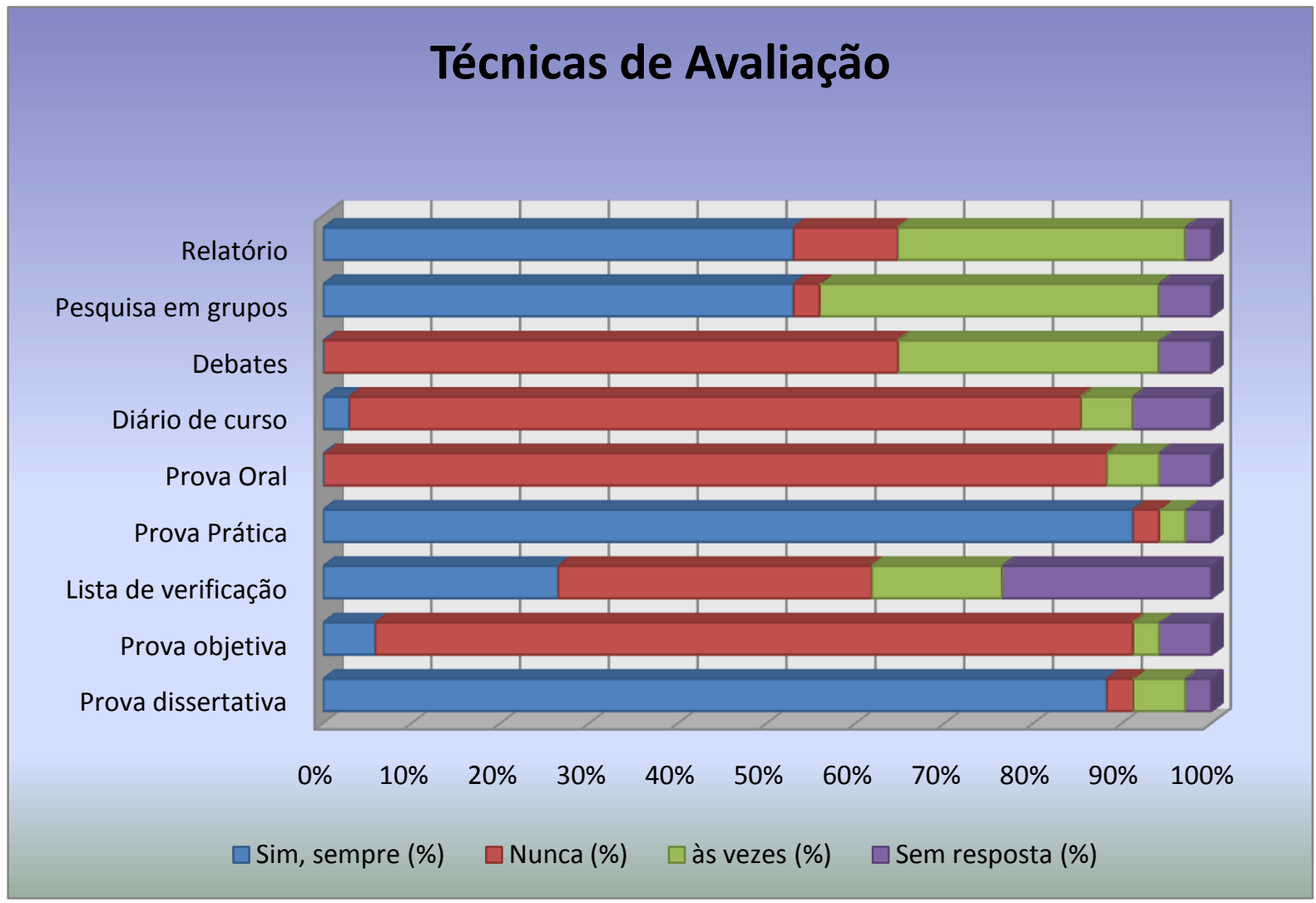

Gráfico 25. Porcentagem das 'técnicas de avaliação' usadas ou não usadas em aula. Amostra composta por 51 respostas. 
No gráfico 25 estão evidenciados os principais instrumentos de avaliação adotados pelos professores responsáveis pela disciplina TF/0123. São eles: Prova dissertativa e Prova Prática. Os itens 'pesquisa em grupos' e 'relatório', pelo fato de serem realizados apenas no final do curso, os restringe ao campo da subjetividade, onde os entrevistados enquadram estes instrumentos tanto no item 'sempre' como no item 'às vezes'.

Masetto (2003, p. 146), baseado em suas experiências em sala de aula, define avaliação como sendo:

$\mathrm{AV}=\mathrm{P}+\mathrm{N} \rightarrow \mathrm{A} / \mathrm{R} \rightarrow \mathrm{J} . \mathrm{A} .:$ Avaliação = prova + nota, que levam o aluno a uma Aprovação ou a uma Reprovação. Em qualquer situação o aluno será Julgado (J. A.) pelo professor, de cujos critérios depende para "passar". ( MASETTO, 2003, p. 146)

A preocupação do Masetto sobre avaliação é demonstrar que ela não está desassociada do processo de aprendizagem. Muito pelo contrário, elas estão interligadas, pois uma interfere no resultado da outra, bem como permite ao aluno e ao professor verificar se os seus objetivos foram alcançados ou não.

Gorow (1977, p. 119), comenta que avaliação não deve ser confundida com mensuração, porque quando se mede, "compara-se alguma coisa com um padrão". No caso de algo produzido pelo estudante, tal qual uma dissertação, não há como se estabelecer uma medida padrão. O que é possível ser feito então é justamente comparar suas características com certos critérios (definidos previamente), fazendo um "julgamento" ou "tomada de decisão" quanto à "qualidade do produto", "verificando-se dessa maneira, se o produto preenche ou não o critério de aceitabilidade". Pois quando se "atribui números para cada critério e chega a uma afirmação numérica total da qualidade" corre-se o risco de "obscurecer o caráter subjetivo da avaliação”. 
Para evitar o risco de perdermos todo o nosso trabalho pedagógico porque não planejamos adequadamente as nossas avaliações do curso e/ou da disciplina, Krasilchik (2004) comenta que devemos levar em conta diversos fatores no planejamento da avaliação de um curso ou unidade de estudo. Entre eles, destacam-se:

a) a periodicidade das provas: é de suma importância que, no início do curso os estudantes sejam informados sobre o número de avaliações que serão submetidos e o intevalo entre elas; além disso, como defende a autora, os alunos passam a conhecer melhor o professor à medida que tomam contato com as suas avaliações e procuram satisfazer essas exigências estipuladas, melhorando consequentemente, o seu desempenho;

b) o tempo: o planejamento do tempo para a execução das tarefas é de suma importância para o bom resultado dos exames;

c) os instrumentos de avaliação: definidos os objetivos a serem verificados, cabe ao professor escolher os melhores instrumentos para coletar as informações sobre o desempenho dos estudantes.

Krasilchik (2004, p. 142) também reforça que, "quando a preparação das provas é feita sem planejamento prévio, há o risco de que elas não representem adequadamente os assuntos e as habilidades mais valorizadas durante o curso".

Estes dados também reforçam a ideia de que a prática docente, nesta disciplina, esta voltado para o ensino e não para a aprendizagem, como já exposto no capítulo 1. Isso somente tende a manter o ensino nos moldes tradicionais, onde o sujeito da aprendizagem passa a vislumbrar a sua formação profissional como um compendio de fórmulas, conceitos, processos que deverá expor nos momentos de avaliação. 


\subsubsection{Os conceitos de flor e de fruto segundo pelos entrevistados da disciplina} Taxonomia de Fanerógamas (TF/0123)

Vamos focar os nossos esforços neste momento para analisar as respostas dos entrevistados da disciplina TF/0123 sobre a concepção deles de flor e fruto. Lembramos que estes estudantes ingressaram no curso há dois anos, quando vimos os seus conceitos iniciais. Neste caso, iremos confrontar as respostas iniciais com as obtidas neste terceiro questionário.

Como os entrevistados passaram por disciplinas específicas de botânica, onde estes temas foram desenvolvidos e trabalhados exaustivamente, o esperado por nós é que os mesmos demonstrem um domínio maior destes conceitos, bem diferente de quando ingressaram.

Q3q12: Levando em consideração a sua formação educacional, você acredita ser $\underline{\text { capaz de reconhecer visualmente uma Flor? }}$

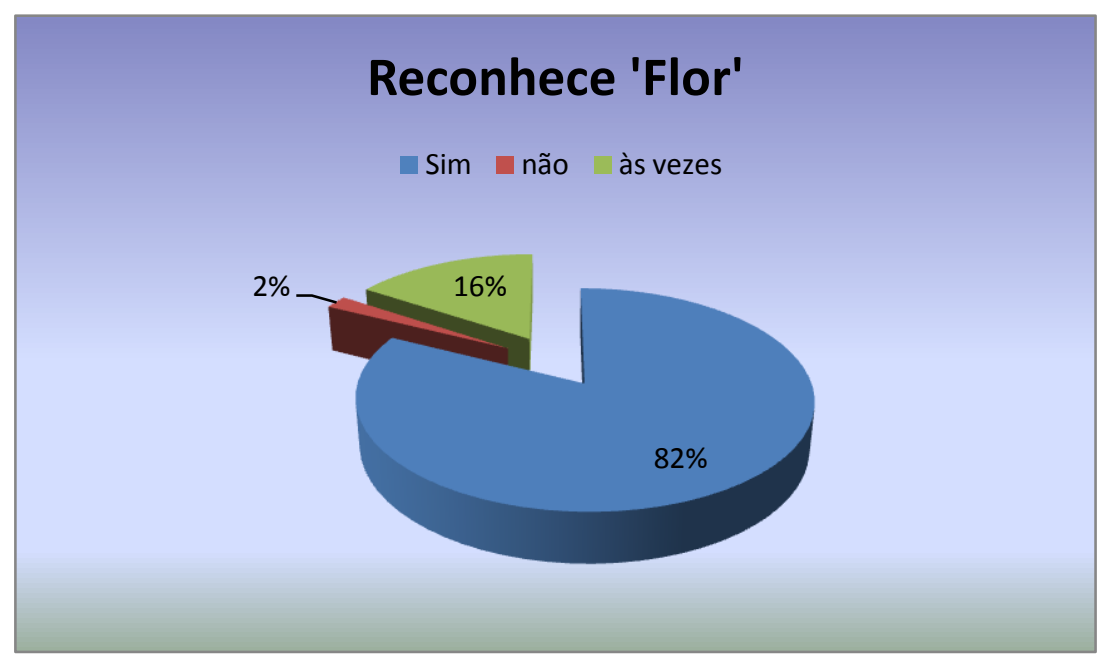

Gráfico 26. Porcentagem dos entrevistados que afirmam reconhecer sempre, às vezes ou não, uma flor. Amostra composta por 51 respostas. 
Comparando o Gráfico 26 com o Gráfico 14, percebe-se um aumento considerável na porcentagem de entrevistados que afirmam serem capazes de reconhecer uma flor, ou seja, houve um aumento de $43.0 \%$ para a opção 'sim'. Mas, até então, desde o início do levantamento de dados, não havia surgido como resposta, o item 'não'. Apenas um entrevistado afirmou que não consegue reconhecer uma 'flor'. Isso se deu, muito provavelmente, como um reflexo do momento em que foi aplicado o questionário, ou seja, no dia da avaliação final de TF/0123.

O próximo item, Q3q13, será discutido posteriormente, como nos casos anteriores, por se tratar da questão onde os entrevistados se expressam sobre o conceito de flor. Aproveitaremos para confrontar as respostas com o item T3p17.

Q3q15: Levando em consideração a sua formação educacional, você seria capaz de reconhecer visualmente um Fruto?

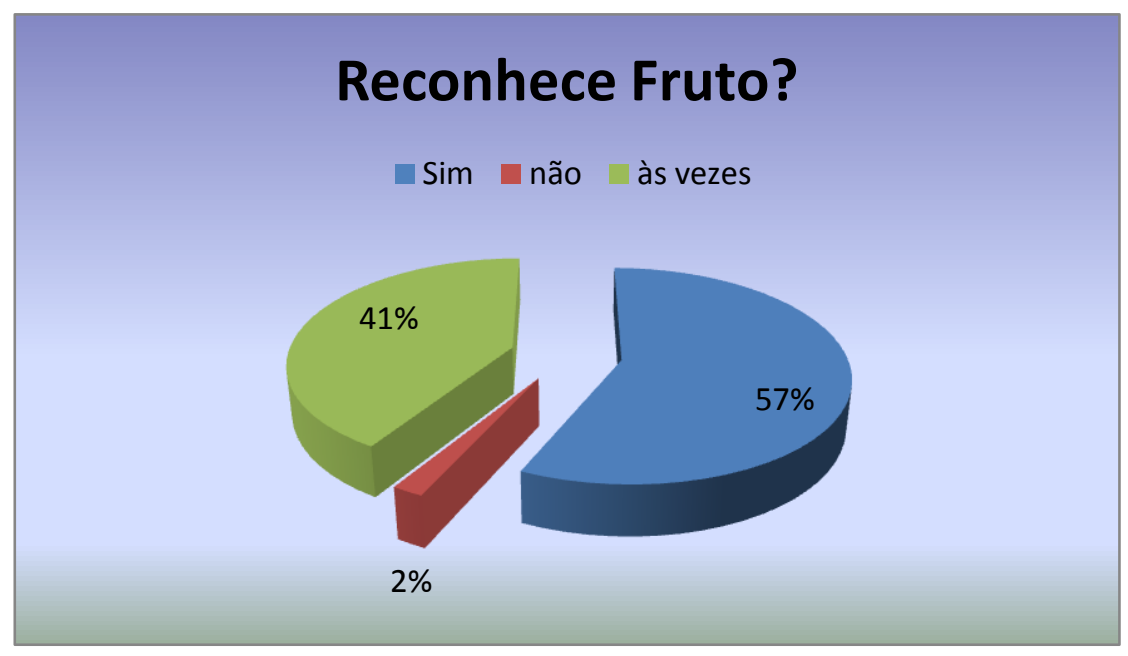

Gráfico 27. Porcentagem dos entrevistados que afirmam reconhecer sempre, às vezes ou não, um fruto. Amostra composta por 51 respostas. 
O esperado no gráfico 27 era um aumento da porcentagem de entrevistados afirmando que conseguem reconhecer um 'fruto', pois, após a aplicação do segundo questionário (Q2), os entrevistados tiveram a oportunidade de cursar duas disciplinas que abordam especificamente este conceito - MAPV/0121 e TF/0123. Ao compararmos os dados do Gráfico 27 com os do Gráfico 15, pode-se observar um aumento de 30.0\% no item 'sim, sempre'. O item 'não' manteve-se inalterado.

Q3q13: Na sua opinião, qual a melhor maneira de se conceituar uma Flor? Escreva em 2 linhas.

Tabela 21. Categorização do conceito de flor pelos entrevistados da disciplina TF/0123

\begin{tabular}{|c|c|c|}
\hline Categoria & Item & $\mathrm{N}^{\text {o }}$ de ocorrências \\
\hline \multirow{7}{*}{ Grupos taxonômicos } & Angiospermas & 16 \\
\hline & Plantas (senso amplo) & 10 \\
\hline & Fanerógamas & 1 \\
\hline & Gimnospermas & 1 \\
\hline & Plantas vasculares & 1 \\
\hline & Plantas com frutos & 1 \\
\hline & Espermatófitas & 1 \\
\hline \multirow{14}{*}{ Partes constituintes da flor } & Carpelo & 13 \\
\hline & Pétalas & 9 \\
\hline & Sépalas & 9 \\
\hline & Androceu & 7 \\
\hline & Gineceu & 7 \\
\hline & Estames & 6 \\
\hline & Ovário & 6 \\
\hline & Perianto & 4 \\
\hline & Cálice & 1 \\
\hline & Caule reduzido & 1 \\
\hline & Corola & 1 \\
\hline & Eixo caulinar & 1 \\
\hline & Estigma & 1 \\
\hline & Estilete & 1 \\
\hline
\end{tabular}


Conclusão

Tabela 21. Categorização do conceito de flor pelos entrevistados da disciplina TF/0123

\begin{tabular}{|c|c|c|}
\hline Categoria & Item & N. ${ }^{\circ}$ de ocorrências \\
\hline \multirow{8}{*}{ Partes constituintes da flor } & Óvulo & 1 \\
\hline & Pistilo & 1 \\
\hline & Tubo polínico & 1 \\
\hline & Verticilos & 1 \\
\hline & Verticilos estéreis & 1 \\
\hline & Verticilos férteis & 1 \\
\hline & Parte feminina & 1 \\
\hline & Parte masculina & 1 \\
\hline \multirow{4}{*}{ Características } & Estrutura reprodutiva & 24 \\
\hline & Órgão reprodutivo & 9 \\
\hline & Estrutura modificada & 1 \\
\hline & Vistosa & 1 \\
\hline \multirow{2}{*}{ Função } & Originar fruto & 4 \\
\hline & Formar sementes & 1 \\
\hline \multirow{2}{*}{ Fenômenos } & Polinização & 1 \\
\hline & Fecundação & 1 \\
\hline Ontogênese & Folha modificada & 3 \\
\hline
\end{tabular}

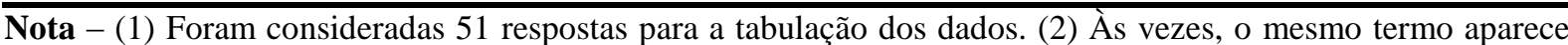
mais de uma vez na resposta do entrevistado.

Após as disciplinas MAPV/0121 e TF/0123, podemos perceber que os entrevistados afirmam que a flor é o órgão exclusivo das angiospermas, em $33.3 \%$ das respostas. Como exemplos, temos:

“Parte reprodutiva das angiospermas". (TF/014/2007) (Negrito meu)

“Estrutura reprodutiva das angiospermas". (TF/008/2007) (Negrito meu)

“Órgão reprodutor de angiospermas com gineceu e androceu (e, na maioria das vezes, perianto)". (TF/022/2007) (Negrito meu) 
O conceito de planta vascular aparece uma única vez, mas o entrevistado resalta que o mesmo se restringe apenas as angiospermas, como podemos perceber na resposta abaixo:

"Flor é uma das estruturas reprodutivas de uma planta vascular angiosperma". (TF/015/2007) (Negrito meu)

O termo 'gimnosperma' também aparece, uma única vez, mas o entrevistado apenas chama a atenção para discordar da ideia de que as gimnospermas apresentam flores. Segue abaixo a transcrição da sua resposta:

"Estrutura reprodutiva das angiospermas (não levo em conta que muitos consideram que as gimnospermas com flor)”. (TF/005/2007) (Negrito meu)

O conceito de planta (senso amplo) ainda aparece em 19.6\% das respostas analisadas. Como exemplo, temos:

"Parte sexual da planta, normalmente formada por perianto, parte feminina e/ou masculina”. (TF/019/2007) (Negrito meu)

"É um órgão reprodutivo de uma planta. O fruto se origina quando a flor é polinizada". (TF/025/2007) (Negrito meu) 
Também percebemos um aumento nos itens constituintes da flor, bem provavelmente estimulados pelo uso das chaves dicotômicas para a identificação e catalogação de espécies do grupo das angiospermas. Por exemplo, apresentamos as seguintes respostas:

“Estrutura reprodutiva portadora de estames, carpelo, ou ambos". (TF/010/2007) (Negrito meu)

“estrutura reprodutiva composta por verticilos estéreis (sépalas e pétalas) e férteis (estames e pistilos) das angiospermas". (TF/022/2007) (Negrito meu)

“conjunto de peças - pétala, sépala, androceu e gineceu, sem a necessidade de estarem sempre juntos". (TF/050/2007) (Negrito meu)

A seguir, apresentamos as respostas do item T3q17: A seguir são apresentadas 6 $\underline{\text { imagens. Considerando o seu conhecimento sobre o conceito de flor, circule em cada uma das }}$ $\underline{\text { imagens a(s) estrutura(s) que você considera como sendo uma flor. Não marque nada nas }}$ imagens em que você não identificar, pelo menos, uma flor.

Esse item nos permite averiguar como os conceitos apresentados acima são empregados pelos entrevistados da disciplina TF/0123 na identificação da estrutura flor (tabela 22). 
Tabela 22. Respostas dos entrevistados da disciplina TF/0123, obtidas em relação ao item T3q17, quando solicitados a circundar o que eles consideram como sendo "uma flor".

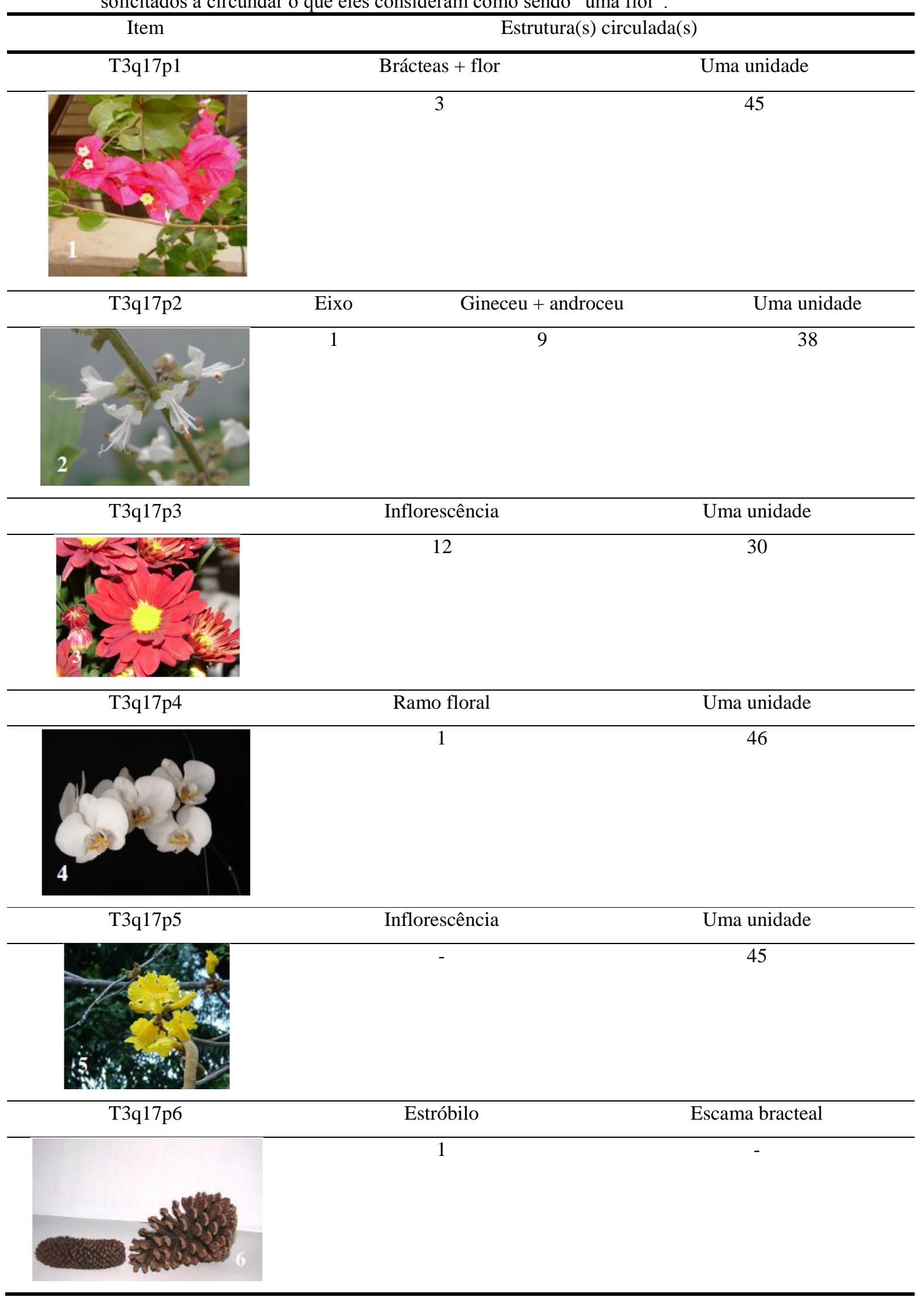

Nota - (1) Foram consideradas 51 respostas para a tabulação dos dados. 
Comparando as repostas da tabela 22 com os dados da tabela 10, podemos perceber que os entrevistados demonstram um maior domínio do conceito de flor. Mesmo assim, ainda percebemos algumas dúvidas em relação à aplicação do conceito em inflorescências do tipo capítulo (T3q17p3). Em relação ao estróbilo, apenas um dos entrevistados considerou o estróbilo como uma flor (TF/005/2007). Todos os outros desconsideraram a imagem. Essa indicação, provavelmente aconteceu, pois o entrevistado ainda apresenta conflitos cognitivos em relação ao conceito a ser adotado (vide resposta destacada do mesmo no item Q3q13).

A seguir, apresentamos as repostas dos entrevistados TF/005/2007, TF/030/2007 e TF/036/2007 em relação ao item T3q17. Vejamos:

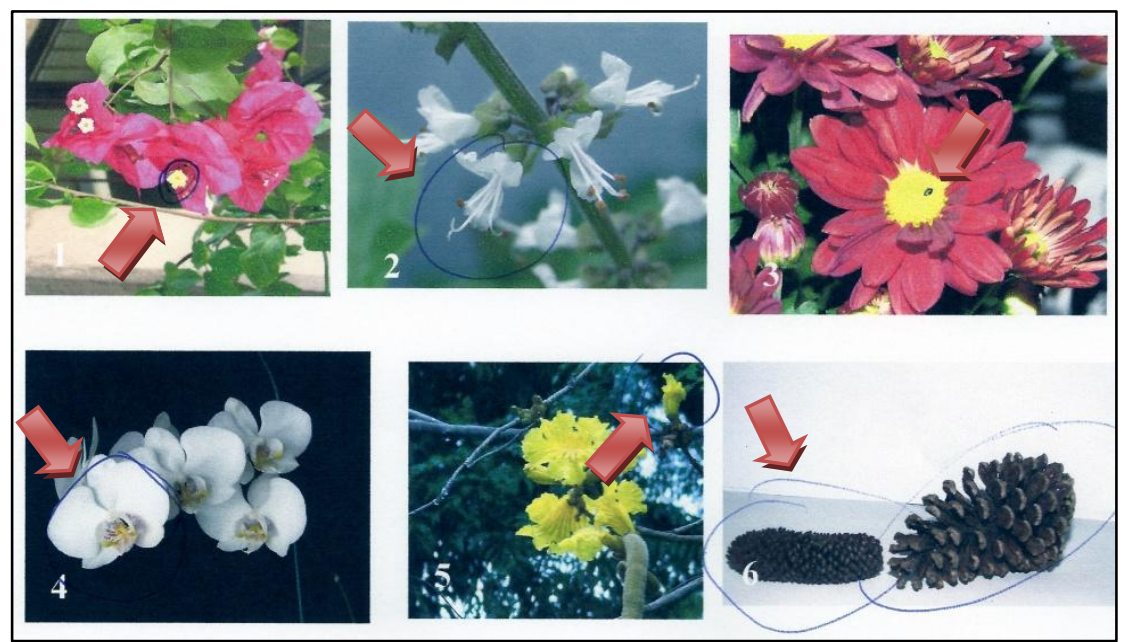

Figura 15. Respostas do entrevistado $\mathrm{TF} / 005 / 2007$ ao item T3q17, sobre o que ele considera como sendo uma flor. As setas em vermelho indicam as marcações do entrevistado.

Como podemos perceber na Fig. 15, o entrevistado TF/005/2007 apresenta um domínio do conceito de flor, haja vista as suas indicações em cada um dos itens, com destaque para dois itens - T3q17p3 e T3q17p6. Em relação ao primeiro item, o entrevistado assinala uma pequena área, sinalizando uma flor entre tantas outras presentes na inflorescência do tipo capítulo. Já em relação ao item T3q17p6, como já dissemos, essa indicação deve-se ao fato do entrevistado apresentar dúvidas sobre o item, sem saber qual conceito aplicar em relação 
ao mesmo. Ele defende a ideia de que a flor é exclusiva das angiospermas, como pudemos constatar na sua resposta acima.

Na próxima figura (Fig. 16), temos as respostas do entrevistado TF/030/2007, em relação ao item supracitado acima.

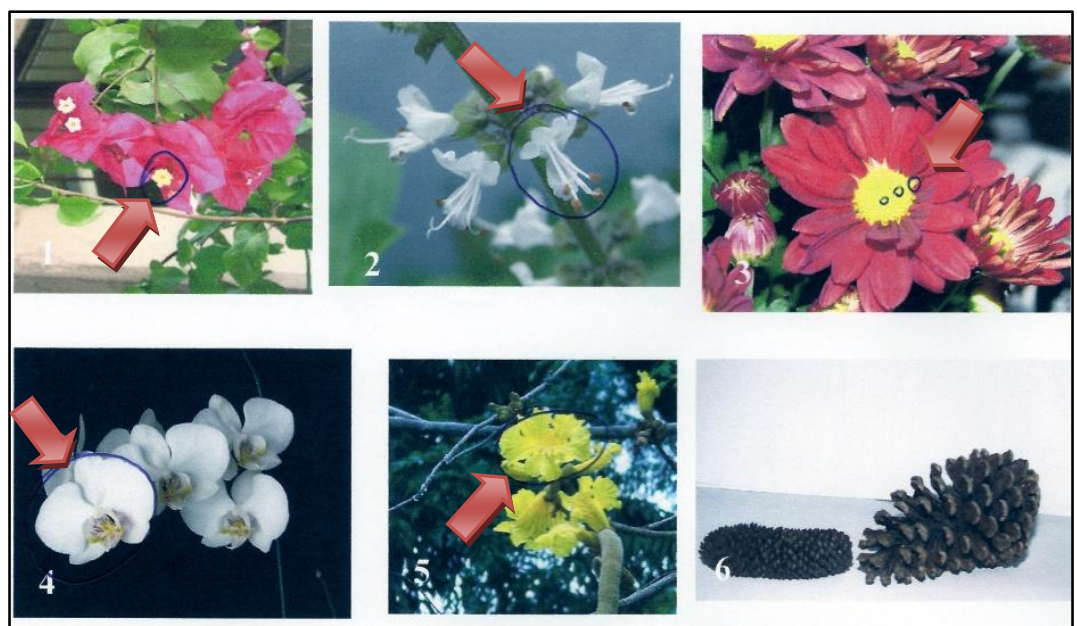

Figura 16. Respostas do entrevistado TF/030/2007 ao item T3q17, sobre o que ele considera como sendo uma flor. As setas em vermelho indicam as marcações do entrevistado.

Ao analisarmos a Fig. 16, podemos inferir que o entrevistado consegue fazer a distinção de flor de inflorescência além de apontar apenas as flores, não fazendo nenhuma marca no item T3q17p6.

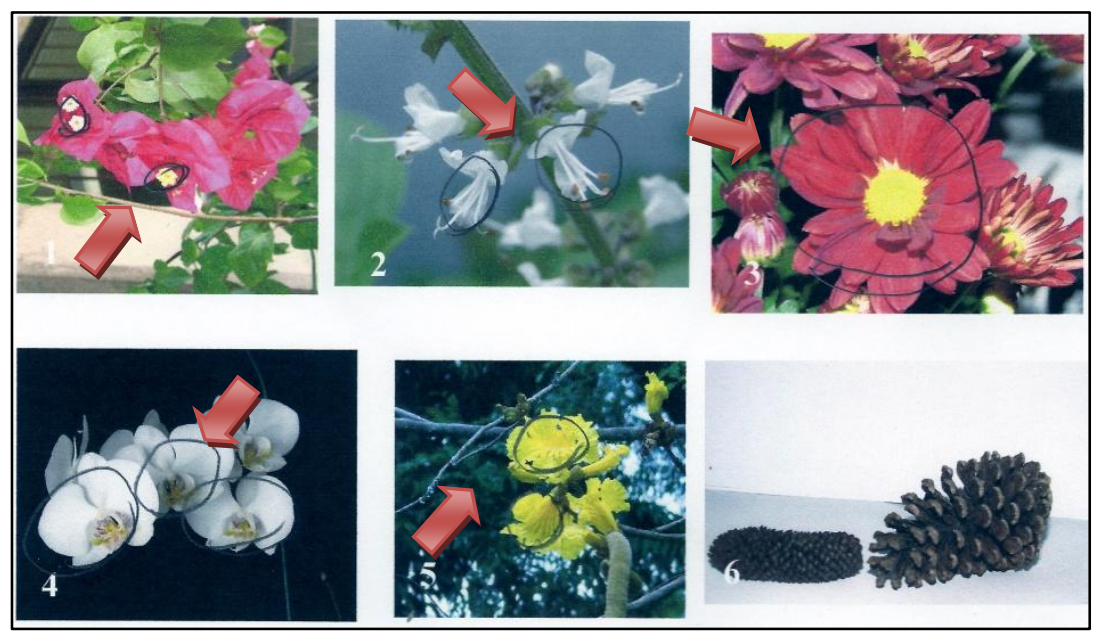

Figura 17. Respostas do entrevistado TF/036/2007 ao item T3q17, sobre o que ele considera como sendo uma flor. As setas em vermelho indicam as marcações do entrevistado. 
Já, no caso do entrevistado TF/036/2007, o mesmo não acontece. O entrevistado citado ainda apresenta dificuldades em identificar uma flor ou sua estrutura. Na Fig. 17 aparecem as suas respostas, onde destacamos os itens T3q17p2, T3q17p3 e T3q17p6. No item T3q17p2, ele assinala principalmente os estames, desconsiderando todo o conjunto. Já no item T3q17p3, ele assinala todo o capítulo. Mas, para este entrevistado, parece-nos que não há dúvidas sobre o estróbilo, pois o mesmo não o assinalou (item T3q17p6).

Apresentaremos a seguir os dados referentes ao item Q3q16: Na sua opinião, qual a melhor maneira de se conceituar Fruto? Escreva em duas linhas.

Tabela 23. Categorização do conceito de fruto pelos entrevistados da disciplina TF/0123

\begin{tabular}{|c|c|c|}
\hline Categoria & Item & N. $^{\circ}$ de ocorrências \\
\hline \multirow{2}{*}{ Características } & Apresenta sementes & 30 \\
\hline & Carnoso & 2 \\
\hline \multirow{3}{*}{ Função } & Envoltório & 14 \\
\hline & Proteção & 7 \\
\hline & Originar nova planta & 1 \\
\hline \multirow{2}{*}{ Fenômeno } & Fecundação & 18 \\
\hline & Partenocarpia & 1 \\
\hline \multirow{10}{*}{ Origem } & Ovário desenvolvido & 40 \\
\hline & Flor & 9 \\
\hline & Ovário fecundado & 9 \\
\hline & Óvulo fecundado & 9 \\
\hline & Carpelo desenvolvido & 4 \\
\hline & Carpelo & 2 \\
\hline & Óvulo (apenas) & 1 \\
\hline & Ovário (apenas) & 1 \\
\hline & Óvulo desenvolvido & 1 \\
\hline & Fertilização da planta & 1 \\
\hline \multirow{3}{*}{ Conceito } & Tegumento protetor & 2 \\
\hline & Carpelo & 2 \\
\hline & Estrutura reprodutiva & 1 \\
\hline
\end{tabular}

Nota - (1) Foram consideradas 51 respostas para a tabulação dos dados. (2) Às vezes, o mesmo termo aparece mais de uma vez na resposta do entrevistado. 
Analisando atentamente a tabela 23 e a comparando com a tabela 11, percebemos que os entrevistados do terceiro questionário são mais concisos para definir fruto. Mesmo assim, ainda percebemos alguns casos de entrevistados que apresentam um conceito equivocado de fruto, como, por exemplo, ao considerar o fruto como derivado do óvulo fecundado (9 respostas) ou que deriva da flor, simplesmente (9 respostas). A seguir, apresentamos algumas das respostas dos entrevistados que ilustram os nossos comentários. Vejamos:

“óvulo fecundado e desenvolvido” (TF/011/2007) (Negrito meu)

“ovário da flor desenvolvido, mantendo sementes em seu interior”. (TF/016/2007) (Negrito meu)

“carpelo envolvendo a semente". (TF/017/2007) (Negrito meu)

“estrutura derivada do ovário, resultante do desenvolvimento dos carpelos após a fecundação dos óvulos, contém as sementes”. (TF/009/2007) (Negrito meu)

Apenas retomando as nossas pontuações iniciais, Os ingressantes do CBio/USP/2006, antes do ingresso na USP, tiveram que responder a uma questão da Fuvest/2006, dissertativa, sobre fruto partenocárpico (fig. 6). Após dois anos no CBio/USP, apenas um entrevistado comenta que o fruto pode desenvolver-se sem que o "ovário" seja fecundado “Desenvolvimento do ovário, fecundado ou não" (TF/011/2007) (negrito meu). Neste caso, o fruto partenocárpico não apresenta semente(s), como é caso da banana (Musa spp. Família: Musaceae). Retomamos este assunto, porque tivemos 30 respostas afirmando que o fruto apresenta semente(s) - condição irrevogável -, reincidindo nas respostas.

Outro dado que consideramos interessante, é o fato dos entrevistados nos questionários anteriores associarem fruto com a função de dispersão. Na tabela 23 não tivemos nenhuma citação. Na disciplina MAPV/0121, em uma das últimas aulas, os estudantes tiveram a 
oportunidade de assistir a um vídeo sobre dispersão e depois reforçar o conceito no laboratório.

Os frutos secos também são outro termo que não aparece na citação dos entrevistados. Neste caso utilizamos ao longo da nossa pesquisa uma imagem do fruto e das sementes da castanha-do-pará (Bertholletia excelsa) para representar esta categoria e foi justamente um dos itens que mais gerou dúvidas entre os entrevistados (vide tabelas 7, 12 e 24).

Esses dados se completam com a análise dos resultados obtidos através do item T3q18 (vide tabela 24).

T3q18: A seguir são apresentadas 6 imagens. Considerando o seu conhecimento $\underline{\text { sobre o conceito de fruto, circule em cada uma das imagens a(s) estrutura(s) que você }}$ considera como sendo um fruto. Não marque nada nas imagens em que você não identificar, pelo menos, um fruto.

O resultado das respostas dos entrevistados em relação ao item $\mathbf{T 3 q 8}$ está demonstrado na tabela 24, onde podemos perceber que ainda apresentam dúvidas no momento de identificar um fruto. Essas dúvidas, como sabemos, são geradas por causa dos próprios conflitos cognitivos que os sujeitos da aprendizagem possuem em decorrência dos conhecimentos prévios adquiridos antes do ingresso na Universidade e posteriormente, quando são submetidos aos mesmos conceitos, mas apresentados em um contexto mais complexo e amplo que é o meio acadêmico. 
Tabela 24. Respostas dos entrevistados da disciplina TF/0123, obtidas em relação ao item T3q18, quando solicitados a circundar o que eles consideram como sendo "um fruto".

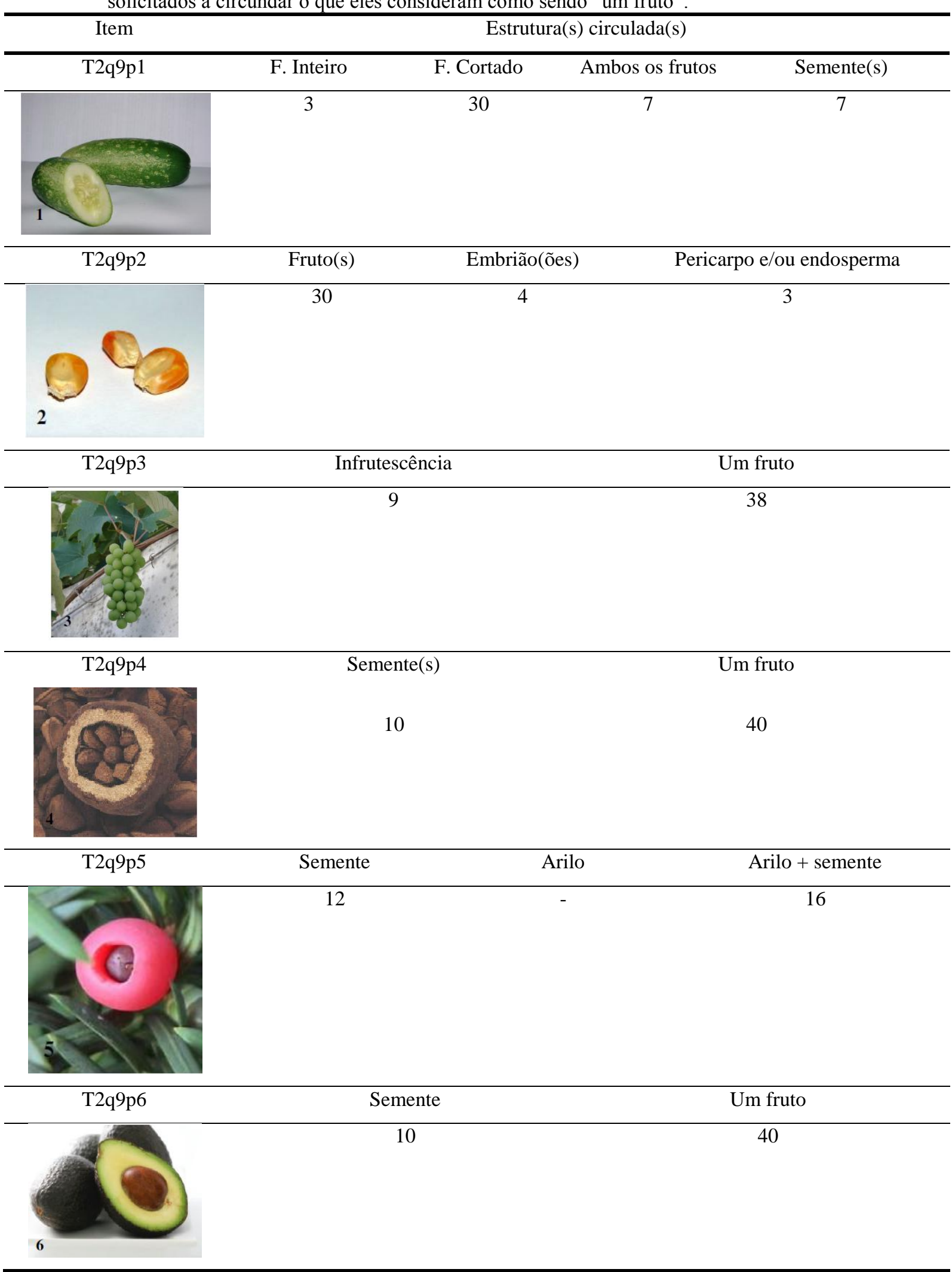

Nota - (1) Foram consideradas 51 respostas para a tabulação dos dados. 
Apresentaremos as respostas de três entrevistados TF/005/2007, TF/030/2007 e TF/036/2007 em relação ao item T3q17, para ilustrar os resultados finais. Vejamos:

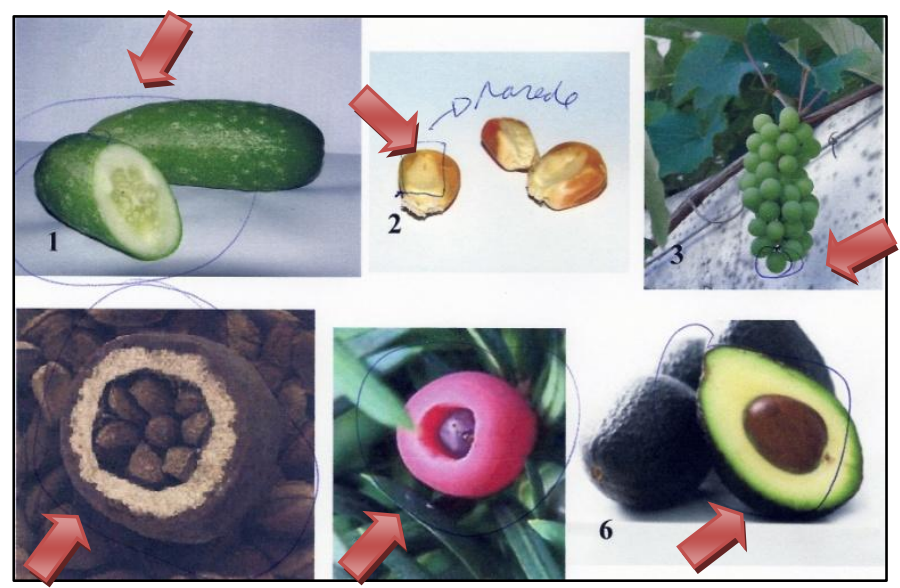

Figura 18. Respostas do entrevistado $T F / 005 / 2007$ ao item T3q18, sobre o que ele considera como sendo um fruto. As setas em vermelho indicam as marcações do entrevistado.

O entrevistado TF/005/2007 assinalou todas as pranchas (figura 18). Iremos comentar apenas duas delas - a prancha T3q18p2, onde o mesmo assinalou apenas a parede do milho. Já comentamos a característica do milho. Por isso, não iremos nos estender. O certo seria ele ter considerado todo o milho como um fruto. O outro item foi o T3q18p5, onde o entrevistado assinala um exemplar das coníferas da família Taxaceae cujas sementes são envoltas por uma taça carnosa - o arilo. Os arilos têm a função de atrair pássaros e outros animais, que os comem e desse modo dispersam as sementes, ou seja, a imagem presente no item T3q18p5 não se trata de um fruto.

Por sua vez, o entrevistado TF/030/2007 apresenta um bom domínio do conteúdo, pois assinalou apenas as estruturas consideradas como frutos (figura 19) ${ }^{48}$.

\footnotetext{
${ }^{48}$ Apenas uma resalva, o mesmo considerou o fruto cortado no item T3q18p1.
} 


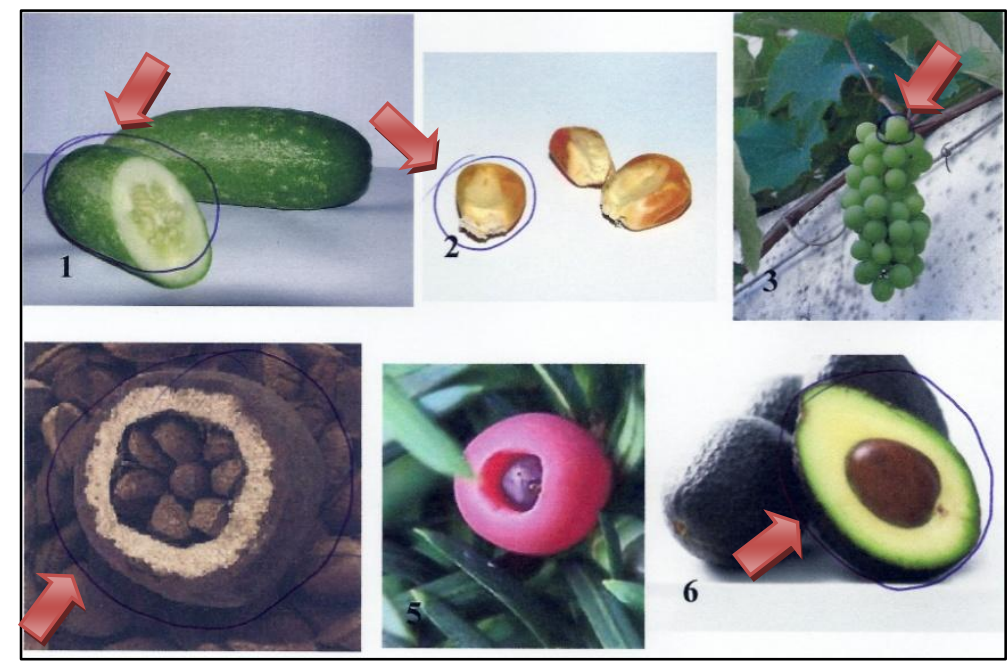

Figura 19. Respostas do entrevistado $\mathrm{TF} / 030 / 2007$ ao item T3q18, sobre o que ele considera como sendo um fruto. As setas em vermelho indicam as marcações do entrevistado.

Finalmente, apresentamos os dados do entrevistado TF/036/2007. Nesse caso, podemos perceber que o entrevistado ainda apresenta dificuldades em distinguir um fruto de sementes. Com exceção dos itens T3q18p3 e T8q18p6, ele assinalou todos os outros, procurando resaltar as suas sementes.

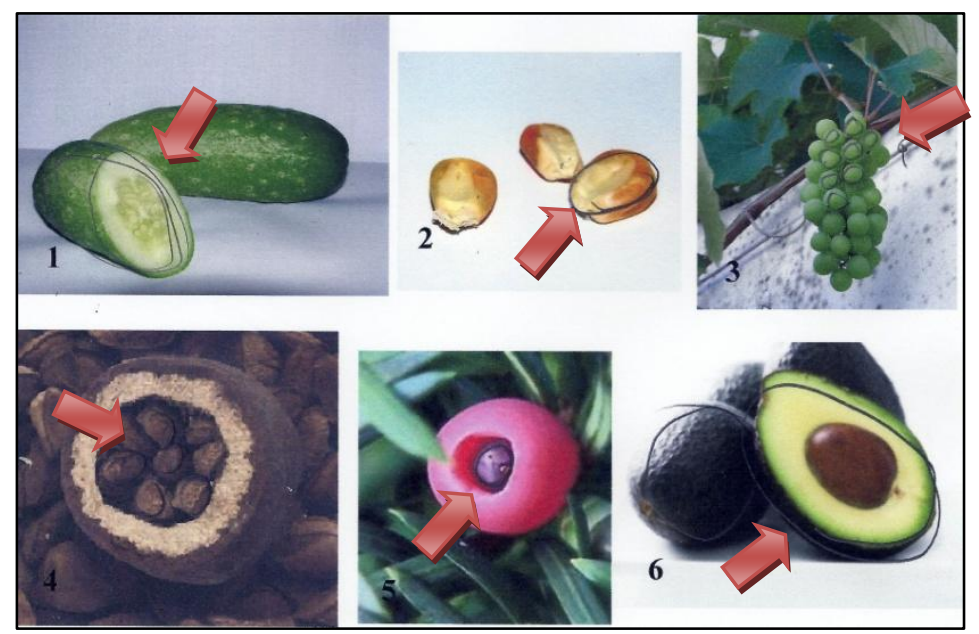

Figura 20. Respostas do entrevistado $\mathrm{TF} / 036 / 2007$ ao item T3q18, sobre o que ele considera como sendo um fruto. As setas em vermelho indicam as marcações do entrevistado.

Justi (2006) defende a ideia de que o ensino de ciências baseia-se em modelos, ou seja, baseia-se em "representações de uma ideia, objeto, acontecimento, processo ou sistema, criado com um objetivo específico". E, esse objetivo específico, muitas vezes, se restringe 
justamente em fazer com que o sujeito da aprendizagem adquira uma "representação mental" ou uma "cópia da realidade" ensinada em sala de aula, reproduzindo o modo de pensar dos cientistas e pesquisadores. "Esses modelos se constroem a partir de uma mescla de elementos presentes tanto na realidade modelada como nos elementos da teoria, e também através de outros elementos externos a eles" (p. 175). Além disso, a construção de modelos sempre implica em "simplificações" e "aproximações" que têm que ser decididas independentemente de requisitos teóricos ou de condições dos dados.

A construção de modelos, geralmente se dá em quatro etapas, a saber: $1^{\text {a }}$ ) definição de um objetivo e a criação, pelo sujeito, de um modelo mental inicial; $2^{\text {a }}$ ) escolha da representação mental mais viável; $3^{\text {a }}$ ) a averiguação da aplicabilidade do modelo proposto, tendo como consequência o seu aceite ou o seu rechaço; d) se o modelo for aceito, a sua socialização aos outros membros da comunidade. Caso contrário, volta-se a $1^{\mathrm{a}}$ etapa.

Mas, para Justi (2006, p. 178) ensinar ciência pautada em modelos não é condenável, muito pelo contrário, é louvável, desde que os sujeitos do conhecimento permitam aos sujeitos da aprendizagem experimentar aspectos excitantes e interessantes da produção do conhecimento científico, de pensar sobre os propósitos da ciência, formular perguntas mais críticas e ousadas, de propor explicações e previsões e avaliar o modelo proposto para que possam obter informações que os ajudem a reformular os mesmos conceitos estudados. Em outras palavras, a autora nos diz que:

[...] a construção de modelos é uma atividade com muito potencial para mobilizar os alunos a "fazer ciência", "pensar sobre ciência" e "desenvolver o pensamento científico e crítico". Desta forma a ciência deixaria de ser algo que se lê nos livros para transformar-se em uma atividade mediante a qual os fenômenos se estudam de uma forma ativa. (JUSTI, 2006, p. 178) 
No ensino superior, isso não é diferente. Como comentamos no capítulo 1 , os esquemas ou modelos didáticos apresentados nada mais são do que modelos a serem aprendidos pelos sujeitos da aprendizagem e depois reproduzidos através da fala, da escrita ou de outras formas simbólicas. Dependendo do perfil do estudante universitário (profundo, superficial, estratégico ou desorganizado) e da abordagem de ensino empregada no ensino superior (tradicional, comportamentalista, humanista, cognitivista ou sociocultural), o aprendizado efetivo de conceitos, de modelos mentais e o estabelecimento de novas estruturas cognitivas não ocorrem. Consequentemente, todos aqueles desafios que o mundo prático impõe atualmente à Universidade não são superados. 


\section{CAPÍTULO 5. CONSIDERAÇÕES FINAIS}

Se, ao escalar uma montanha na direção de uma estrela, o viajante se deixa absorver demasiadamente pelos problemas da escalada, ele está arriscando-se a esquecer qual a estrela que o guia... Se o sacristão da catedral se preocupa demais com a posição dos bancos, arrisca-se a esquecer de que está servindo a um deus.

Saint-Exupéry - Cartas a um refém.

Neste trabalho nos propusemos verificar como os Ingressantes do CBio/USP/2006 lidam com a sua formação profissional e que tipo de influência a Universidade consegue exercer sobre as concepções de flor e fruto.

Para tanto, buscamos verificar os conceitos prévios que estes sujeitos da aprendizagem trouxeram do ensino básico como ponto de partida para uma jornada investigativa que durou dois anos. Ao longo deste período, nos familiarizamos com esta "tribo" e sua academia, refletindo sobre a sua relação com o saber ao mesmo tempo em que nós também sofríamos influência da formação acadêmica a que estávamos sujeitos, refletindo em nossos questionários as adequações que acreditávamos necessárias para, no final do processo, conseguirmos vislumbrar algumas das considerações finais que faremos a seguir.

O que nos foi possível constatar através do primeiro questionário e do primeiro teste, referente ao perfil dos sujeitos da aprendizagem e a sua relação com o objeto do conhecimento é que os mesmos apresentaram um "saber memorizado", mas não aplicável. A transposição do modelo para o objeto de estudo, quando ocorreu, se deu com muitas dificuldades, haja vista os resultados apresentados nas análises do item 4.1.

Os sujeitos da aprendizagem apresentaram dúvidas sobre qual referencial adotar, pois os mesmos estavam totalmente alheios ao mundo acadêmico. As referências se restringiam 
apenas as aulas, ao material didático utilizado e aos professores do ensino básico bem como aos professores dos "Cursinhos".

Muitos dos Ingressantes do CBio/USP/2006 chegaram com dúvidas sobre a possibilidade de evidenciarem uma flor e/ou um fruto.

Após um ano de imersão no ensino superior, percebemos pouquíssimas alterações nos conceitos dos Ingressantes do CBio/USP/2006. Até o momento, os conceitos de flor e de fruto foram abordados de forma aleatória pelos mesmos, em um contexto mais amplo. $\mathrm{O}$ vocabulário fica mais preciso, mas as dúvidas sobre a aplicação dos conceitos permanecem.

Finalmente, ao término de dois anos de curso, os sujeitos da aprendizagem buscam adequar as suas "falas" aos modelos mentais apresentados pelas disciplinas estudadas, ou seja, os estudantes procuram adequar a sua fala ao dos sujeitos do conhecimento (professores pesquisadores). Apresentam um aumento considerável de vocabulário, o que favorece uma visão mais clara do significado dos objetos de conhecimento, mas, ao mesmo tempo, também ampliam as suas possibilidades de atribuírem significados divergentes das concepções do mundo acadêmico atribuídos aos signos. Em relação à formação profissional, os sujeitos analisados apresentam uma motivação pessoal voltada para a conclusão do curso dentro do prazo mínimo estabelecido pela Instituição de Ensino (Universidade de São Paulo - SP) além de poderem exercer o bacharelado. Também apresentam, na sua maioria, uma relação de superficialidade com os estudos (vide item 4.3.1). Finalmente, constatamos que, no nosso caso das práticas metodológicas voltadas para o ensino superior, foi possível constatar que elas ainda se baseiam principalmente nas "falas" dos sujeitos do conhecimento, ou seja, as aulas são praticamente expositivas e as práticas de laboratório acontecem como um reforço das "falas" iniciais; por sua vez, as práticas avaliativas ainda são marcadas por dois tipos: a prova dissertativa e a prova prática (vide item 4.3.2). 


\section{BIBLIOGRAFIA}

AEBLI, Hans. Prática de ensino: formas fundamentais de ensino elementa, médio e superior. Trad. De Maria T. de Oliveira Huland. 3. ed. Petrópolis, RJ: Ed. Vozes, 1973. 287 p.

ALBERTS, Bruce. Redefining Science Education. In: Science. 23 jan. 2009. Vol. 323, n. 5913, p. 437.

AMABIS, J. M. \& MARTHO, G. R. Biologia dos organismos: a diversidade dos seres vivos, anatomia e fisiologia de plantas e animais. 2. ed. São Paulo: Moderna Ed. , 2004. v. II.

ANTUNHA, Heladio Cesar Gonçalves. Universidade de São Paulo: Fundação e Reforma. São Paulo: Centro Regional de Pesquisas Educacionais do Sudeste, 1974. V. 10. 264 p.

AUSUBEL, D. P. The psychology of meaning verbal learning. Nova York: Grune Stratton, 1963.

Educacional Psycology: a congnitive view. Nova York: Holt, 1968.

BARDIN, Laurence. Análise de Conteúdo. 3. ed. São Paulo: Ed. Edições 70 Brasil, 2008. $288 \mathrm{p}$.

BECHER, Tony. Tribus y territories académicos. La indagación intelectual y las culturas de las disciplinas. Trad. Andrea Menegatto. Barcelona: Editorial Gediza, 2001. 253 p.

BENEDITO, Vicença et al. La formacion universitaria a debate. Barcelona: Publicacions de la Universitat de Barcelona, 1995.

BIREAUD, Annie. Os métodos Pedagógicos no Ensino Superior. Trad. Irene Lima Mendes. Porto Cordex: Porto Ed., 1995. 224 p.

BORDENAVE, J. D; PEREIRA, A. M. Estratégias de ensino-aprendizagem. 28. ed. Petrópolis, RJ: Vozes, 2007, 316 p. 
BRASIL. Lei n. ${ }^{\circ} 9.394$ de 20 de dezembro de 1996. Estabelece as diretrizes e bases da educação nacional. Diário Oficial da República Federativa do Brasil, Brasília, DF, n. ${ }^{2}$ 248, dez. 1996. p. 27.833-27.841.

Lei n. 6684 de 03 de setembro de 1979. Regulamenta as profissões de Biólogo e de Biomédico, cria o Conselho Federal e os Conselhos Regionais de Biologia e Biomedicina, e dá outras providências. Diário Oficial da República Federativa do Brasil, Brasília, DF, setembro de 1979.

Lei $\mathrm{n}^{\circ} 7017$ de 03 de agosto de 1983. Dispõe sobre o desmembramento dos Conselhos Federal e Regionais de Biomedicina e de Biologia. Diário Oficial da República Federativa do Brasil, Brasília, DF, agosto de 1983.

Constituição da República Federativa do Brasil de 1988: (última atualização: Emenda Constitucional $\mathrm{n}^{\text {o }}$ 56, de 20/12/2007 - DOU 21/12/2007). Disponível em: $<$ http://www.trt02.gov.br/geral/Tribunal2/Legis/CF88/CF88_1.html>. Acessado em: 26/08/2008.

Decreto n. 2.306 , de 19 de Agosto de 1997 (DOU, 20 de Agosto de 1997 - Seção 1 - p. 17.991).

BROOKFIELD, Stephen D. Understanding and Facilitting Adult Leaning - São Francisco, EUA: Jossey-Boss Publishers, 1986.

CALDEIRA, P. Z. Evolução das Orientações para o Estudo em Estudantes do Ensino Superior. In: ANAIS - Educação e Desenvolvimento. Quinta da Torre: Unidade de Investigação Educação e Desenvolvimento, 2000.

CHARLOT, Bernard. O sujeito e a relação com o saber. In: BARBOSA, R. L. L. (ORG.) Formação de Educadores: desafios e perpectivas. São Paulo: Ed. UNESP, 2003.

CHAUÍ, M. "Janela da alma, espelho do mundo". In: NOVAES, A. (org.). O olhar. 6. Ed. São Paulo: Companhia das letras, 1997. 496 p.

A Universidade pública sob nova perspectiva. In: Revista Brasileira de Educação. Set/out/Nov/dez/ 2003. № 24, p. 5 -15CAPRIGLIONE, L. Dezesseis escolas de São Paulo têm 36\% das vagas de 'elite' da USP. Folha de São Paulo. São Paulo, 29 de abril de 2005. Colégios. Especial 2. 
CHAVES, Sandramara Matias. Avaliação da aprendizagem no ensino superior. In: MOROSINI, M. C. Professor do Ensino Superior: identidade, docência e formação. 2. ed. ampl. Brasília: Plano Ed., 2001. 163 p.

COELHO NETTO, J. Teixeira. Semiótica, Informação e Comunicação. 6. ed. São Paulo: Ed. Perspectiva, 2003.

DELIZOICOV, D. ANGOTTI, J. A., PERNAMBUCO, M. M. Ensino de Ciências: fundamentos e métodos. São Paulo, Cortez Ed., 2003.

DELORS, Jacques. Educação: um tesouro a descobrir. 2. ed. São Paulo: Cortez, 2003.

DORNAS, Roberto. Diretrizes e Bases da Educação Nacional: comentários e anotações. 2. ed. Belo Horizonte: 1997. 86 p.

DOXSEY, Jaime Roy. A sala universitária como comunidade de aprendizagem e contexto psicossociológico para mudança. In: Ensino Superior: Reflexões e experiências. Isabel Franchi Cappelletti; Marcos Tarciso Masetto (org.). São Paulo: Educ/Editora da Puc, 1986.

ENTWISTLE, N. Contrasting perspectives on learning. In: MARTON, F., ENTWISTLE, N. HOUNSELL, D. (Ed.). Experience of learning. Edinburgo: Scottish Academic Press, 1984. A model of teaching - learning. Processes derived from research on Student Learning. Comunicação apresentada na Internacional Conference on Cognitive Process in Student Learning. Lancaster: Lancaster University, 1985.

O Ensino e a qualidade da aprendizagem no ensino superior. Análise Psicológica, série 5, 1, 141-153, 1986.

. Motivational factors in students approaches to learning. In: SCHMECK, R.R. (Ed.). Learning Strategies and Learning Styles. New York: Plenum Press, 1988. p. 21-51.

ENTWISTLE, N., KOZÉKI, B., POLLITT. Measuring Styles of Learning and Motivation. Europan Journal of Psycology of Education, 2, 183-203, 1987.

ERICKSON, F. Qualitatives methods in research on teaching. In: WITTROCK, Merlin C. (Ed.). Handbook of research on teaching. Londres: Macmilian, 1986. P. 119-161. 
FACTOR, L; KOOSER, R. Value Pressupposition in Science textbook, a critical bibliography. Galesburg: Know College, s. d.

FERREIRA, A. B. H. Miniaurélio - Século XXI Escolar. 4. ed. Rio de Janeiro: Nova Fronteira Ed., 2001.

FOUREZ, Gérald. Educar. Docentes, alunos, escolas, ética, sociedade. Trad. José Augusto da Silva. Aparecida, SP: Ideias e Letras, 2008. 320 p.

A construção das ciências: Introdução à Filosofia e à Ética das Ciências. Trad. De Paulo Rouanet. São Paulo: Ed. da Universidade Estadual Paulista, 1995. 319 p.

FREIRE, P. PEDAGOGIA DA AUTONOMIA: Saberes necessários à prática educativa. 25. ed. Rio de Janeiro, Paz e Terra Ed., 2002.

Pedagogia do Oprimido. 18. ed. Rio de Janeiro: Paz e Terra, 1988. 184 p. (O mundo, hoje, v. 21)

. Concientización. Buenos Aires: Educiones Busqueda, 1974a.

. Uma educação para a liberdade. Porto: Textos Marginais, 18975 b.

. Educação como prática da liberdade. Rio de Janeiro: Paz e Terra, 1974b.

Educação. O sonho Possível. In: BRANDÃO, C. R. (Org.). Educador: Vida e Morte. Rio de Janeiro: Graal, 1982, p. 89- 101f.

FUNARO, Vânia M. B. de Oliveira et al. (Coord.) Diretrizes para apresentação de dissertações e teses da USP: documento eletrônico e impresso. São Paulo: SIBi-USP, 2004. $110 \mathrm{p}$.

GEERTZ, C. Local Knowledge. Nova York: Books, 1983.

GODOY, A. S. Ambiente de ensino preferido por alunos de terceiro grau. Um estudo comparativo. São Paulo: F. E. Tese de doutorado, 1989.

GONÇAlveS, M. T.; AQUINO, Z., M.T. ; SILVA, Z. B. Antologia das Antologias: 101 poetas brasileiros “revisados". São Paulo: Musa Editora, 1995. 540 p. 
GOROW, Frank F. O jogo da aprendizagem. Estratégias para professores. Trad. Geraldina Porto Witter e José Fernando Bittencourt Lomanaco. São Paulo: Ed. EPU, 1977. 148 p.

HAYDT, Regina Cazaux. Avaliação do Processo Ensino-Aprendizagem. 6. ed. São Paulo: Ed. Ática, 2007. 159 p.

HOUAISS, Antônio, VILlAR, Mauro de Salles, FRANCO, Francisco M. de Mello. Minidicionário Houaiss da Língua Portuguesa. 3. ed. Rio de Janeiro: Ed. Objetiva- Ed. Moderna, 2009. 976 p.

HUNT, D. E. Person - Environment Interaction: A challenge Found Wanting Before It Was Tried. Review of Educational Research. 45(2): 209-230, 1975.

HUNT, D. E. et al. Student Conceptual Level and Models of Teaching. Theoretical and Empirical Coordination of Two Models. Interchange. 5 (3): 19-30, 1974.

INSTITUTO NACIONAL DE ESTUDOS E PESQUISAS EDUCACIONAIS - INEP. 2000. Resultados e Tendências da Educação Superior - Brasil, Brasília. . 2004. Censo da Educação Superior: Resumo Técnico - 2004, Brasília.

JANOTTI, Aldo. Origens da universidade: a singularidade do caso português. 2. ed. São Paulo: Editora da Universidade de São Paulo, 1992. 232 p.

JUDD, WALTER S. et al. Sistemática Vegetal: um enfoque filogenético. Trad. André Olmos Simões et al. 3. ed. Porto Alegre: Artmed, 2009. 632 p.

JUSTI, Rosária. La enseñanza de ciencias baseada en la elaboración de modelos. Enseñanza de las ciencias. 24 (2), 173-184, 2006.

KOURGANOFF, Wladimir. A face oculta da universidade. Trad. Cláudia Schilling e Fátima Murad. São Paulo: Editora da Universidade Estadual Paulista, 1990. 305 p.

KRASILCHIK, M. Práticas de Ensino de Biologia. 4. ed. São Paulo, Editora da Universidade de São Paulo, 2004.

LATOUR, Bruno. Ciência em ação: como seguir cientistas e engenheiros sociedade afora. Trad. Ivone c. Benedetti. São Paulo: UNESP, 2000. 439 p. 
LAVILlE, C. \& DIONNE, J. A Construção do Saber: Manual de metodologia da pesquisa em ciências humanas. Porto Alegre, ARTMED Ed., 1999.

LEVINAS, Marcelo Leonardo. Conflictos del conocimiento y dilemas de la educación. Buenos Aires: Aique, 1998. 231 p. (Psicologia cognitiva y educación)

LINHARES, S. \& GEWANDSZNAJDER, F. Biologia Hoje: Os seres vivos. 7. ed. São Paulo, Ática Ed., 1998.v.II.

LOPES, S. Bio - Introdução ao estudo dos seres vivos. 2. ed. São Paulo, Saraiva Ed., 2003.v. II.

LÜDKE, M. \& ANDRÉ, M.E.D.A. Pesquisa em Educação: abordagens qualitativas. 8. ed. São Paulo, E.P.U., 2004.

LYOTARD, L.F. La condition post-moderne. Les Editions de Minuit, 1979, 109 p.

MARCONDES, A. C. \& LAMMOGLIA, D. A. Biologia - Ciência da Vida. São Paulo: Atual, 1997. v. II.

MARCONI, M. A. \& LAKATOS, E. M. Fundamentos de Metodologia Científica. 5. ed. São Paulo, Atlas Ed., 2003.

MARCONI, M. A.; LAKATOS, E. M. Fundamentos de Metodologia Científica. 5. ed. São Paulo: Atlas, 2003. 311 p.

MARTON, F. Beyond Individual differences. Educational Psycology, 3, 289-3003. 1983. Approaches to learning. In: MARTON, F., ENTWISTLE, N., HOUNSELL, D. (Ed.). Experience of Learning. Edinburgo: Scottish Academic Press. 1984.

MASETTO, M. T. Docência Universitária: Repensando a aula. In: TEODORO, A.; VASCONCElOS, M. L. Ensinar e aprender no Ensino Superior. 2. ed. São Paulo: Ed. Mackenzie; Cortez, 2005. 124 p.

Competência Pedagógica do professor universitário. São Paulo: Summus, 2003. 194 p. 
Aulas Vivas. Tese (e prática) de livre docência. São Paulo: MG Editores Associados, 1992. 104 p.

MAYR, Ernest. Isto é biologia. A ciência do mundo vivo. Trad. Claudio Angelo. São Paulo: Companhia das Letras, 2008. 428 p.

MEDEIROS, João Bosco. Redação Científica: a prática de fichamentos, resumos, resenhas. 10 ed. São Paulo: Atlas, 2008. 321 p.

MENEZES, Nanuza Luíza de, et al. Anatomia e morfologia de plantas vasculares. São Paulo, São Carlos, SP: USP - UFSCar, 2007. 185 p.

MILLER, George E. Ensino e Aprendizagem nas Escolas Médicas. São Paulo: SP ia Ed. Nac. 1967.

MINOGUE, Kenneth. O conceito de Universidade. Trad. Jorge Eira Garcia Vieira. Brasília: Editora Universidade de Brasília, 1981. 180 p.

MIZUKAMI, M. G. N. Ensino: As abordagens do processo. 8. ed. São Paulo: E.P.U., 1986. $119 \mathrm{p}$.

MIZUKAMI, M. G. N. et al. Escola e aprendizagem da docência: Processos de investigação e formação. São Carlos: EdUFSCar, 2003. 176 p.

MICOTTI, Maria Cecília de Oliveira. As propostas didáticas e a prática escolar. Educação: Teoria e Prática. v. 5, nº 8, jan - jun, 1997.

MOLES, A. L. L'Affiche dans la Société Urbaine. Paris: Dunod, 1970.

MOOS, R. H. A Typology of Junior High and High School classrooms. American Educacional Resarch Journal. 15 (1): 53-66, 1978.

MOOS, R. H.; MOOS, B.S. Classroom Social Chimate and Student Absences and Grades. Journal of Educacional Psichology. 70 (2): 263-269, 1978.

NÉRICI, Imídeo Guiseppe. Didática: Uma introdução. São Paulo: Ed. Atlas, 1983.

PAUlinO, W. R. Biologia Atual: Seres Vivos; Fisiologia. 9. ed. São Paulo, Ática Ed.,1997.v.II. 
PEIRCE, Charles S. Semiótica. São Paulo: Perspectiva, 1977.

PIMENTA, Selma Garrido, ANASTASIOU, Léa das Graças Camargos. Docência do Ensino Superior. São Paulo: Cortez, 2002. 280 p.

PIRANI, José Rubens, MELLO-SILVA, Renato, SANO, Paulo Takeo. Taxonomia de Fanerógamas. São Paulo: USP, 2003.125 p.

RANIERI, Nina Beatriz. Educação Superior, Direito e Estado: Na Lei de Diretrizes e Bases (Lei no 9.394/96). São Paulo: Editora da Universidade de São Paulo, Fapesp, 2000. 408 p.

. Aspectos Jurídicos da Autonomia Universitária no Brasil. In: STEINER, João E., MALNIC, Gerhard (Orgs.).Ensino Superior: conceito e dinâmica. São Paulo: Editora da Universidade de São Paulo. 2006. 360 p.

RASHDALL, Hastings. The Universities of Europe in the Middle Ages. ed. F. M. Powicke e B. Emden, Oxford, 1936.

RAVEN, P. H., EVERT, R. F., EICHHORN, S. E. Biologia Vegetal. 6. ed. Coord. Trad. J. E. Kraus. Rio de Janeiro, Guanabara Koogan Ed., 2001.

RAW, I., MENNUCCI, L., KRASILCHIK, M. Didática 4: A biologia e o homem. São Paulo: Edusp, 2001.

REUCHLIN, M. Reflexions sur lês finalités et le fonctionnement de l'enseignement universitaire. In: L'Orientation scolaire et professionnelle. v. 18, n. ${ }^{\circ}$ 1, Março de 1989, p. 85-96.

ROSA, João Guimarães. Grande Sertão: veredas. 20. ed. Rio de Janeiro: Nova Fronteira, 2005. $624 \mathrm{p}$.

SACRISTÁN, José Gimeno. A educação que ainda é possível: ensaios sobre uma cultura para a educação. Porto Alegre: Artmed, 2007.

SCHWARTZMAN, Simon. A universidade de São Paulo e a questão universitária no Brasil. In: STEINER, João E., MALNIC, Gerhard (orgs.).Ensino Superior: conceito e dinâmica. São Paulo: Editora da Universidade de São Paulo. 2006. 360 p. 
SHÖN, D. A. The reflective practitioner: how professionals tink in action. USA: Basic Books Inc., 1983.

SNOW, C. P. As duas culturas e uma segunda leitura: Uma versão ampliada das Duas Culturas e a Revolução Científica. Trad. Geraldo Gerson de Souza; Renato de Azevedo Rezende Neto. São Paulo: Editora da Universidade de São Paulo, 1995, 136 p.

SNYDERS, G. Pedagogia Progressista. Coimbra: Almedina, 1974.

SOARES, J. L. Dicionário etimológico e circunstanciado de Biologia. São Paulo, Scipione Ed., 1993.

SORDI, M. H. Avaliação da aprendizagem em tempos de mudança: a inovação ao alcance do educador comprometido. In: VEIGA, I. P. A.; CASTANHO, M. E. L. M. Pedagogia Universitária: a aula em foco. 5. ed. Campinas, SP: Papirus, 2000. 248 p.

VERAS, Eduardo Souza Lobão, CARVALHO, Marlene Araújo de. O ensino superior brasileiro $e$ os seus professores. Disponível em: $\langle$ http://www.ufpi.br/mesteduc/eventos/ivencontro/GT10/ensino_superiorbrasileiro.pdf $\rangle$. Acessado em: 25/08/2008.

VIANNA, Heraldo Marelim. Testes em educação. São Paulo: IBRASA/ Fundação Carlos Chagas, 1973.

VYGOTSKY, L. S. Psicologia Pedagógica. Trad. Paulo Bezerra. 2. ed. São Paulo: Martins Fontes, 2004. 561 p.

TAIZ, Lincoln; ZEIGNER, Eduardo. Fisiologia vegetal. Eliane Romanato Santarém et al. 4 ed. Porto Alegre: Artmed, 2009. 848 p.

TROLL, W. Die Infloreszenzen, Typologie una Stellung in Aufbau des. Vegetation Skörpers. 2 v. Gustav Fischer, Jena, Germany. 1964/1969.

WITTER, José Sebastião. USP/50 anos: registros de um debate. São Paulo: Reitoria da Universidade de São Paulo, 1984. 142 p. 


\section{ANEXO A - QUESTIONÁRIO APLICADO AOS ALUNOS DA DISCIPLINA FAUNA, FLORA E AMBIENTE}

\section{Prezado(a) aluno(a)!}

Este questionário refere-se a uma pesquisa de mestrado e não tem qualquer finalidade referente à atribuição de notas ou conceitos. Agradecemos muito a sua disponibilidade em nos auxiliar!

Todas as informações registradas por você serão confidenciais e, caso queira, não é necessário se identificar.

O questionário não terá impacto, de forma alguma, em sua nota nesta ou em qualquer outra disciplina.

1) Em que tipo de escola você cursou o Ensino Médio? se estudou em escolas alternadas, marques as duas opçōes $\theta$ diga quanto tempo em cada:

( ) Pública (Estadual, Municipal, Federal) Quantos anos?

( ) Privada (particular) Quantos anos?

2) Qual o(s) nome(s) da(s) Instituiçāo(ōes) onde você cursou o Ensino Médio?

3) O curso de Ciências Biológicas na USP é o seu primeiro curso superior?

( ) Sim.

( ) Nāo. Que outro curso já cursou ou ainda cursa?

Concluiu? Sim ( ) Nāo ( )

4) Durante o Ensino Médio, o professor e/ou a Instituiçāo onde você estudou, adotou algum tipo de material pedagógico de Biologia?

( ) Sim.

( ) Nāo. (Se "não", desconsidere a próxima pergunta e vá para a pergunta 6)

5) Qual(is) o(s) tipo(s) de material(is) pedagógico(s) adotado(s)? Anote na frente o nome da(s) obra(s) đ'ou autor(es) que você se lembrar (pode assinalar mais de uma opçāo).

( ) Apostilas:

( ) Livro Didático:

( ) Material confeccionado pelo professor (especificar):

( ) Outro(s): I

6) Durante o Ensino Médio, você teve aulas de Botânica?

( ) Sim.

( ) Nāo. (Se "não", desconsidere a próxima pergunta e vá para a pergunta 8)

7) Durante as aulas de Botânica, foi discutido o conceito de Flor?

( ) Sim.

( ) Nāo. 
8) Durante ou após ter concluído o Ensino Médio, você fez curso preparatório para o Vestibular (Cursinho)?

( ) Sim.

( ) Não.

9) Você acredita ser capaz de reconhecer visualmente uma Flor?

( ) Sim

( ) Nāo

() As vezes.

10) Na sua opiniāo, qual a melhor maneira de se conceituar uma Flor? Escreva em 2 linhas.

11) Durante o seu Ensino Médio, foi explorado o conceito de Fruto? (Se você respondeu não na pergunta de número 6 , desconsidere esta questāo $\Theta$ vá para a questāo de número 12).

( ) Sim.

( ) Nāo

12) Você seria capaz de reconhecer visualmente um Fruto?

( ) Sim.

( ) Não

() As vezes.

13) Na sua opiniāo, qual a melhor maneira de se conceituar Fruto? Escreva em duas linhas.

Caso seja necessário aprofundar este assunto, voce concorda em ser contatado?

( ) Sim

( ) Naio.

Em caso positivo, deixe-nos o seu nome, e-mail e telefone e/ou celular.

Nome:

e-mail:

tel.

celular:

Muito obrigado pela sua atenção e contribuição para com a nossa pesquisa.

Atenciosamentel

Ricardo Henrique Pucinelli 


\section{ANEXO B - TESTE APLICADO AOS ALUNOS DA DISCIPLINA FAUNA, FLORA E AMBIENTE}

14) A seguir são apresentadas 6 imagens. Considerando o seu conhecimento sobre o conceito de flor, circule em cada uma das imagens a(s) estrutura(s) que voce considera como sendo uma flor. Não marque nada nas imagens em que voce nđ̃o identificar, pelo menos, uma flor.
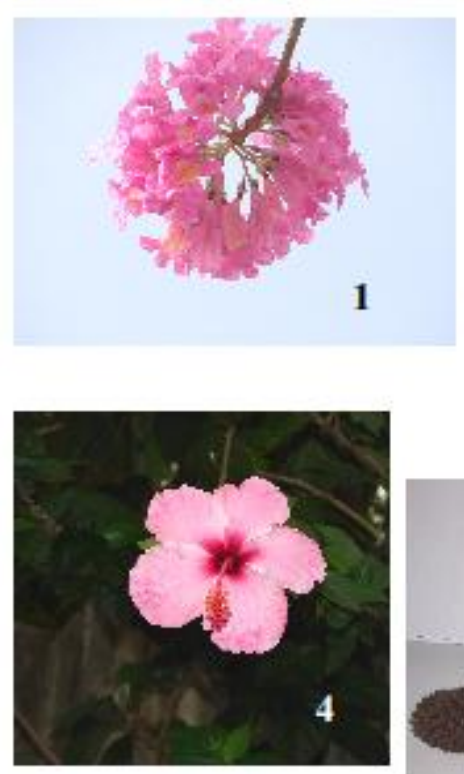
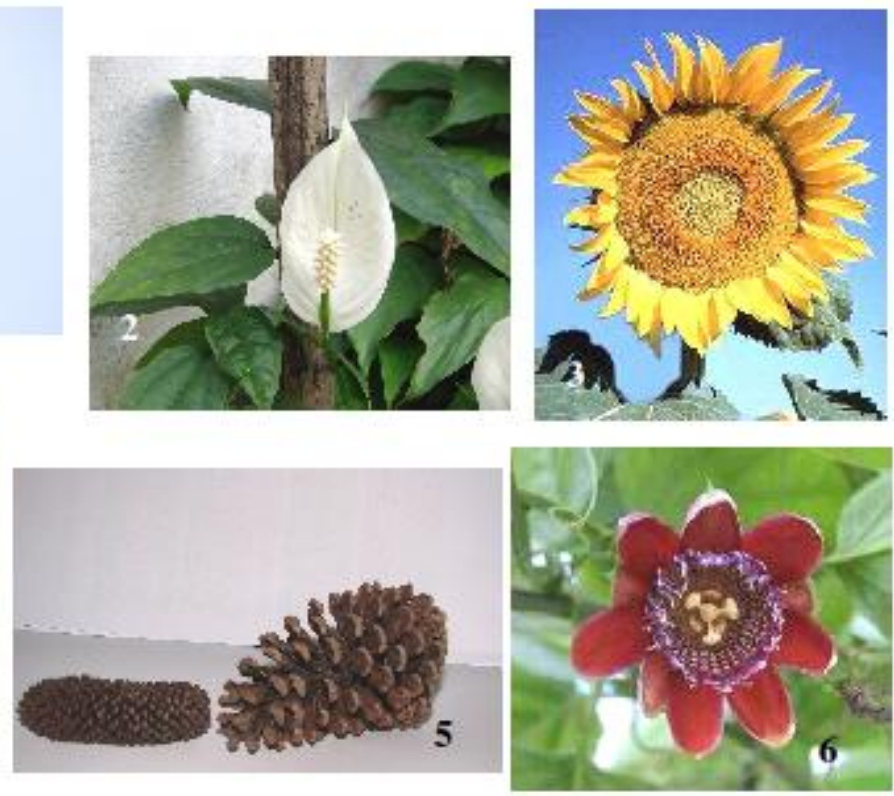

15) A seguir são apresentadas 5 imagens. Considerando o seu conhecimento sobre o conceito de fruto, circule em cada uma das imagens a(s) estrutura(s) que voce considera como sendo um fruto. Nåo marque nada nas imagens em que você não identificar, pelo menos, um fruto.
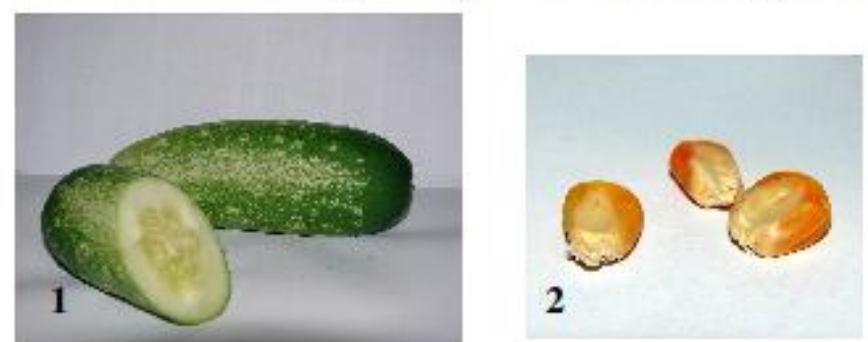
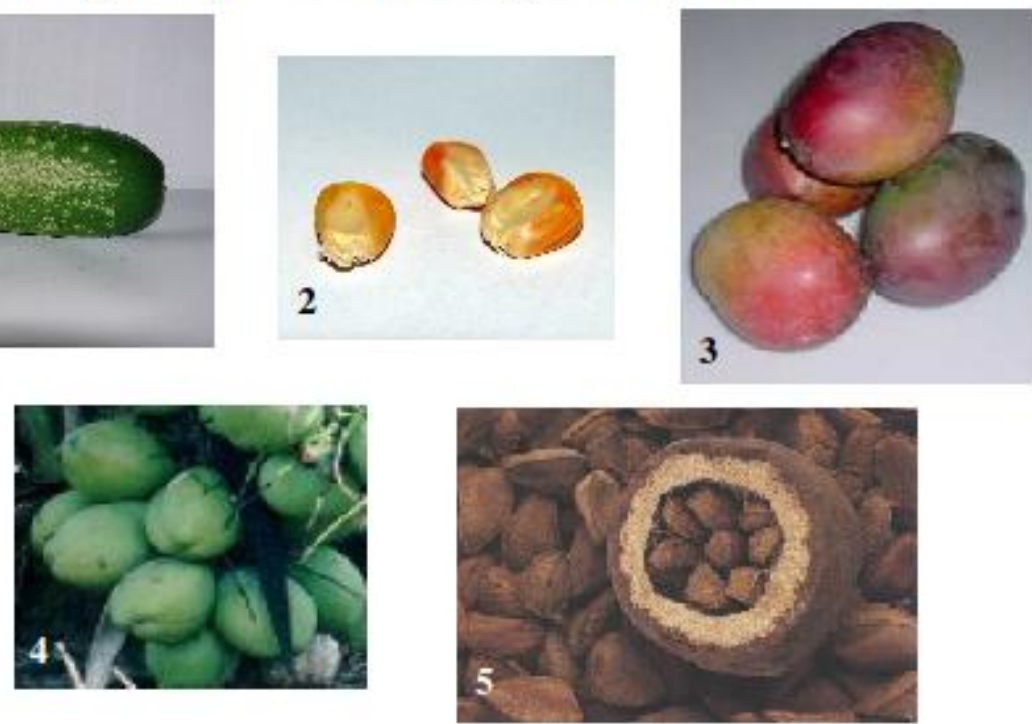

Ohservaça: Caso voce queira comentar alguma das escolhas e/ou citar dúvidas, use o verso da folha. 


\section{ANEXO C - QUESTIONÁRIO APLICADO AOS ALUNOS DA DISCIPLINA MORFOLOGIA E ANATOMIA DE PLANTAS VASCULARES}

\section{Prezado(a) aluno(a)!}

Este questionário refere-se a uma pesquisa de mestrado e não tem qualquer finalidade referente à atribuição de notas ou conœitos. Agradeœemos muito a sua disponibilidade em nos auxiliar!

Todas as informações registradas por você serão confidenciais e, caso queira, não é necessário se identificar.

O questionário não terá impacto, de forma alguma, em sua nota nesta ou em qualquer outra disciplina.

1) Este é o seu segundo ano na USP, como aluno do Curso de Ciências Biológicas? (Se não, indique na frente quantos anos já está cursando Ciências Biológicas.)

( ) Sim

( ) Nāo

2) Ao longo deste período em que você se encontra na USP, cursando Ciências Biológicas, você já teve alguma disciplina que abordou os conceitos de flor $\theta$ fruto? (Se sim, indique na frente a(s) disciplina(s).)

( ) Sim

( ) Nāo

3) Você já desenvolveu algum tipo de estágio em laboratório e/ou pesquisa de campo, onde o seu terma principal foi a pesquisa com plantas vasculares, mais especificamente, angiospermas? ( $\mathrm{S}_{\Theta}$ sim, indique na frente o estágio $\theta$ o seu orientador)

( ) Sim

( ) Nāo

4) Levando em consideraçāo a sua formaçāo educacional, você acredita ser capaz de reconhecer visualmente uma Flor?

( ) Sim

( ) Nāo

( ) As vezes.

5) Na sua opiniāo, qual a melhor maneira de se conceituar uma Flor? Escreva em 2 linhas.

6) Levando em consideraçāo a sua formaçāo educacional, você seria capaz de reconhecer visualmente um Fruto?

( ) Sim.

( ) Nāo.

() As vezes.

7) Na sua opiniāo, qual a melhor maneira de se conceituar Fruto? Escreva em duas linhas. 
Caso seja necessário aprofundar este assunto, voce concorda em ser contatado?

( ) Sim.

( ) Naio

Em caso positivo, deixe-nos o seu nome, e-mail e telefone e/ou celular:

Nome:

e-mail:

tel.

celular:

Muito obrigado pela sua atenção e contribuição para com a nossa pesquisa.

Atenciosamente!

Ricardo Henrique Pucinelli 


\section{ANEXO D - TESTE APLICADO AOS ALUNOS DA DISCIPLINA MORFOLOGIA E ANATOMIA DE PLANTAS VASCULARES}

8) A seguir são apresentadas 6 imagens. Considerando o seu conhecimento sobre o conceito de flor, circule em cada uma das imagens a(s) estrutura(s) que voce considera como sendo uma flor. Nåo marque nada nas imagens em que você nå̃o identificar, pelo menos, uma flor.
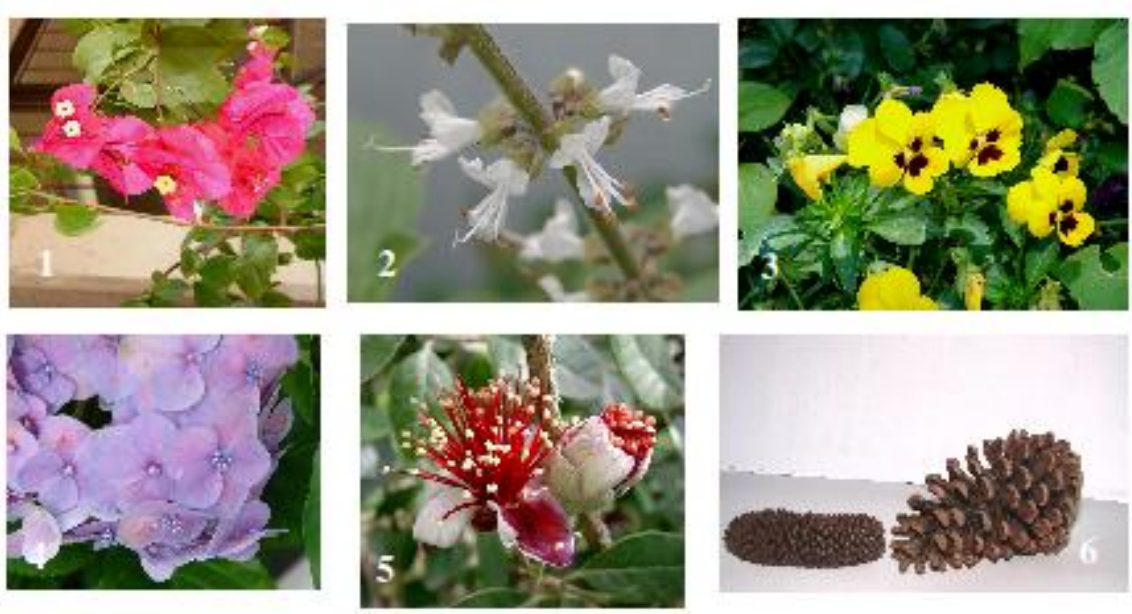

9) A seguir såo apresentadas 6 imagens. Considerando o seu conhecimento sobre o conceito de fruto, circule em cada uma das imagens a(s) estrutura(s) que você considera como sendo um fruto. Nåo marque nada nas imagens em que você năo identificar, pelo menos, um fruto.
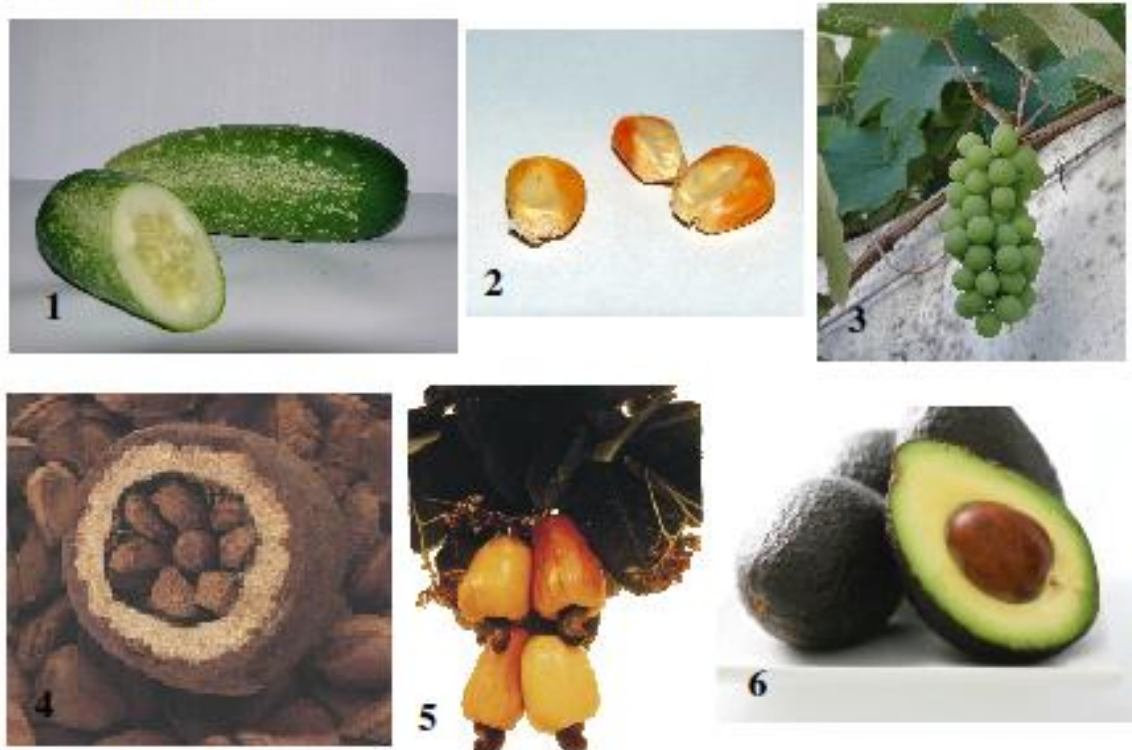

Observaça: Caso voce queira comentar alguma das escolhas e/ou citar dúvidas, use o verso da folha. 


\section{ANEXO E - QUESTIONÁRIO APLICADO AOS ALUNOS DA DISCIPLINA TAXONOMIA DE FANERÓGAMAS}

\section{Prezado(a) aluno(a)!}

Este questionário refere-se a uma pesquisa de mestrado e não tem qualquer finalidade referente à atribuição de notas ou conceitos. Agradecemos muito a sua disponibilidade em nos auxiliar!

Todas as informações registradas por você serão confidenciais e, caso queira, não é necessário se identificar.

O questionário não terá impacto, de forma alguma, em sua nota nesta ou em qualquer outra disciplina.

1) Este é o seu segundo ano na USP, como aluno do Curso de Ciências Biológicas? (Se 'não', indique na frente quantos anos já está cursando Ciências Biológicas.)

( ) Sim.

( ) Nāo.

2) Ao longo deste período em que você se encontra na USP, cursando Ciências Biológicas, você já teve alguma disciplina que abordou os conceitos de flor e fruto? (Se 'sim', indique na frente a(s) disciplina(s).)

( ) Sim.

( ) Nāo.

3) Qual o número de créditos que você cursa por semana?

( ) 8. ( ) 16. ( ) 20. ( ) 24. ( ) Outro:

4) Qual a sua motivaçāo para freqūentar as aulas?

5) Você realiza leituras sobre os assuntos estudados além das indicadas pelo professor?
( ) Sim.
( ) Nāo.
( ) Às vezes.

6) Você realiza pesquisas na internet sobre os temas abordados em sala de aula? Se 'sim, sempre' ou 'às vezes', em que momento dos seus estudos?

( ) Sim, sempre.

( ) Nāo.

( ) Ás vezes.

7) Você realiza pesquisas na biblioteca sobre os ternas abordados em sala de aula? Se 'sim, sempre' ou 'às vezes', em que momento dos seus estudos?

( ) Sim, sempre.

( ) Nāo.

() As vezes. 
8) Você já desenvolveu algum tipo de estágio em laboratório e/ou pesquisa de campo, onde o seu tema principal foi a pesquisa com plantas vasculares? ( $S_{e}$ 'sim', indique na frente o estágio $\theta 0$ seu orientador)

( ) Sim.

( ) Nāo

9) Você percebe alguma ligaçāo entre a disciplina Taxonomia de Fanerógamas com alguma outra que você já tenha cursado durante a sua formaçāo no curso de Ciências Biológica pela USP? Se 'sim, sempre' ou 'às vezes', qual a ligaçāo?

( ) Sim, sempre.

( ) Nāo.

( ) Às vezes.

10) Por que você estuda?

11) Durante a Disciplina de Taxonomia de Fanerógamas, qual(is) modalidade(s) didática(s) o(s) professor(es) abordou(aram) durante as suas aulas? Leve em consideraçāo os números 1 sempre, 2 - nunca, 3 - às vezes, para indicar a frequência que você percebeu o uso desses recursos durante a sua formaçāo.

( ) aula expositiva

( ) Debate com a classe toda

( ) Estudo de caso (resolver problemas)

( ) Ensino com pesquisa (elaborar relatório científico, debater com colegas os resultados obtidos)

( ) Pequenos grupos com tarefas diversificadas

( ) Seminário

( ) leituras

( ) Recursos audiovisuais (TV, vídeo, projeto multimidiático, retroprojetor, computador, etc.)

( ) Excursāo

( ) Aulas práticas de laboratório

Outro(s): (

/( ) /( )

12) Levando em consideraçāo a sua formaçāo educacional, você acredita ser capaz de reconhecer visualmente uma Flor?

( ) Sim.

( ) Nāo.

()As vezes. 
13) Na sua opiniāo, qual a melhor maneira de se conceituar uma Flor? Escreva em 2 linhas.

14) Qual(is) instrumentos de avaliaçāo você foi submetido ao longo da disciplina Taxonomia de Fanerógamas. Leve em consideraçāo os números 1 - sempre, 2 - nunca, 3 - às vezes, para indicar a freqüência que você percebeu o uso desses instrumentos durante a sua avaliaçāo.

( ) Prova discursiva, dissertativa ou ensaio.

( ) Prova objetiva (questōes de múltipla escolha, questōes de verdadeiro-falso)

( ) Lista de verificaçāo

( ) Prova prática

( ) Prova oral

( ) diário de curso

( ) Debates

( ) Pesquisa em grupo

( ) Relatório

Outro(s): ( ) /( ) /( )

15) Levando em consideraçāo a sua formaçāo educacional, você seria capaz de reconhecer visualmente um Fruto?

( ) Sim.

( ) Nāo.

() As vezes.

16) Na sua opiniāo, qual a melhor maneira de se conceituar Fruto? Escreva em duas linhas.

Caso seja necessário aprofundar este assunto, você concorda em ser contatado? ( ) Sim.

( ) Não.

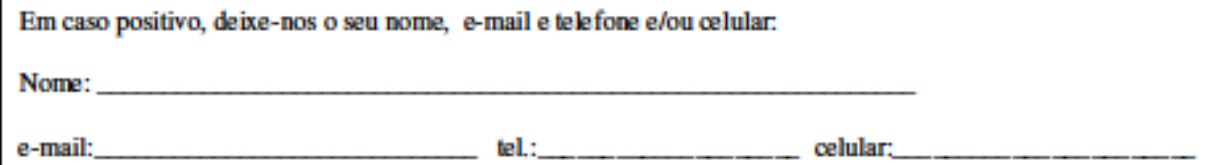

Muito obrigado pela sua atenção e contribuição para com a nossa pesquisa.

Atenciosamente!

Ricardo Henrique Pucinelli (pucinelli@hotmail.com) 


\section{ANEXO F - TESTE APLICADO AOS ALUNOS DA DISCIPLINA TAXONOMIA DE FANERÓGAMAS}

17) A seguir såo apresentadas 6 imagens. Considerando o seu conhecimento sobre o conceito de flor, circule em cada uma das imagens a(s) estrutura(s) que voce considera como sendo uma flor. Nåo marque nada nas imagens em que voce nåo identificar, pelo menos, uma flor.
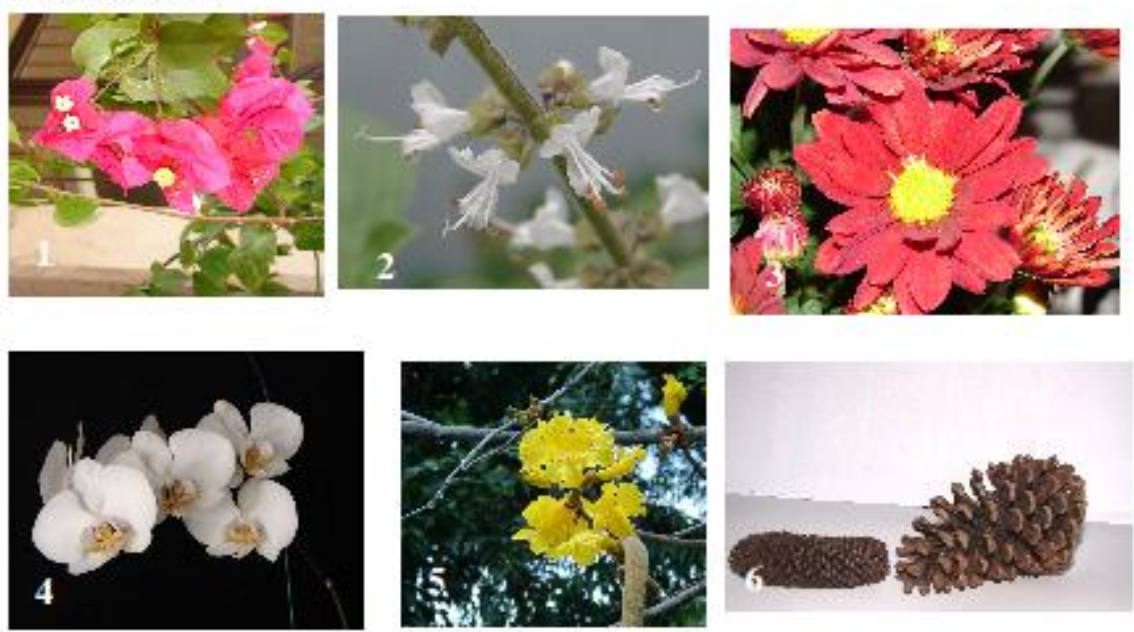

18) A seguir sđ̃o apresentadas 6 imagens. Considerando o seu conhecimento sobre o conceito de fruto, circule em cada uma das imagens a(s) estrutura(s) que voce considera como sendo um fruto. Nåo marque nada nas imagens em que voce não identificar, pelo menos, um fruto.
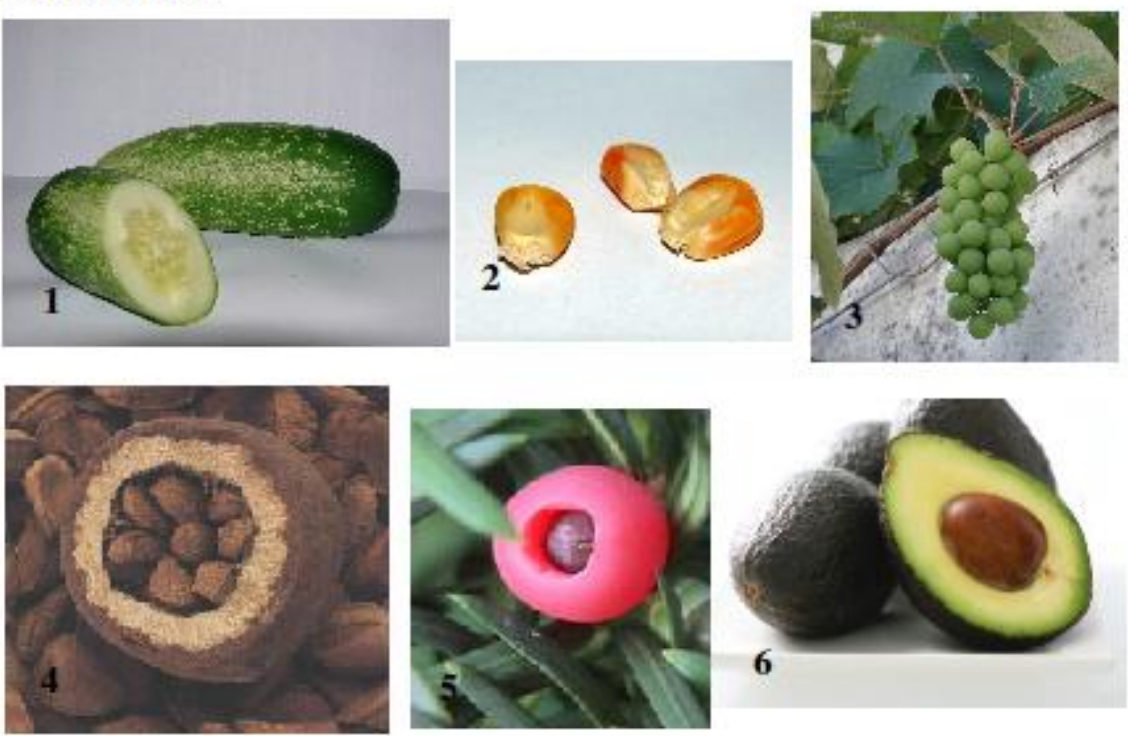

Observaça: Caso voce queira comentar alguma das escolhas e/ou citar dúvidas, use o verso da folha. 


\title{
ANEXO G - PROGRAMA DA DISCIPLINA ANATOMIA E MORFOLOGIA DE PLANTAS VASCULARES
}

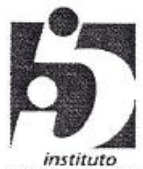

UNIVERSIDADE DE SÃO PAULO INSTITUTO DE BIOCIÊNCIAS DEPARTAMENTO DE BOTÂNICA

instituto
de biociéncias BIB-121 - Morfologia e Anatomia de Plantas Vasculares 2004

\section{MORFOLOGIA E ANATOMIA DE PLANTAS} VASCULARES

BIB-121

\section{APRESENTAÇÃO E CRONOGRAMA}

\author{
2007




\section{ANEXO G - PROGRAMA DA DISCIPLINA ANATOMIA E MORFOLOGIA DE PLANTAS VASCULARES (CONTINUAÇÃO)}

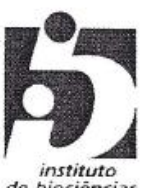

de instituto

\section{UNIVERSIDADE DE SÃO PAULO \\ INSTITUTO DE BIOCIÊNCIAS DEPARTAMENTO DE BOTÂNICA}

BIB-121 - Morfologia e Anatomia de Plantas Vasculares 2004

\section{EQUIPE DOCENTE}

Professores:

Prof. Dra. Gladys Flavia Melo-Pinna:

Prof. Dr. Gregório C.T. Ceccantini:

gfmelopinna@hotmail.com

Prof. Dr. José Rubens Pirani:

gregorio@usp.br

jrpirani@ib.usp.br

Profa. Dra. Lúcia Garcez Lohmann:

llohmann@usp.br

Profa Dra Maria Emilia Maranhão Estelita:

estelita@ib.usp.br

Profa Dra Nanuza Luiza de Menezes:

nanuza@usp.br

Profa Dra Veronica Angyalossy (Responsável):

vangyalossy@ib.usp.br

Monitores de Graduação:

Dayane Tarabay

José Hernandes Lopes Filho

dayanetarabay@yahoo.com.br zehernades@gmail.com

Monitores de Graduação - Voluntários:

Ana Carolina de Almeida

Danilo Eugênio de França Lopes

Gustavo Borin Ferreira

Pedro Poli

Raphael Pigozzo

Rebeca Verônica Ribeiro Viana anacarolusp@yahoo.com.br dan eugenio@yahoo.com.br gu84@uol.com.br pvpoli@hotmail.com rpigozzo@gmail.com r-veronica@uol.com.br

Monitores Programa de Aperfeiçoamento de Ensino (PAE):

Deusa Deise Santos de Abreu

Giuliano Locosselli

deusa dd@hotmail.com locosselli@yahoo.com.br

Técnica: Gisele Rodrigues de Oliveira Costa: giselecosta@hotmail.com

\section{OBJETIVOS DA DISCIPLINA}

1. Estabelecer um panorama amplo e introdutório à morfologia e anatomia das plantas vasculares.

2. Apresentar metodologias essenciais para análise das estruturas externas e internas das plantas vasculares.

Rua do Matão - Travessa 14 no. 321 - CEP 05508-900 - Cidade Universitária São Paulo - Brasil - http://www.ib.usp.br 


\section{ANEXO G - PROGRAMA DA DISCIPLINA ANATOMIA E MORFOLOGIA DE PLANTAS VASCULARES (CONTINUAÇÃO)}

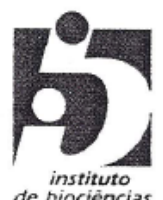

instituto
de biociências

\section{UNIVERSIDADE DE SÃO PAULO \\ INSTITUTO DE BIOCIÊNCIAS \\ DEPARTAMENTO DE BOTÂNICA}

BIB-121 - Morfologia e Anatomia de Plantas Vasculares 2004

3. Fornecer subsídios para as disciplinas de Taxonomia de Fanerógamas, Fisiologia Vegetal, Recursos Econômicos Vegetais e Ecologia Vegetal.

4. Desenvolver o espírito científico através da compreensão e da análise critica dos tópicos abordados.

\section{ORGANIZAÇÃO}

A disciplina está subdividida em dois módulos, a saber: Módulo I "Morfologia das plantas vasculares" e Módulo II - "Anatomia das plantas vasculares".

\section{a. Aulas}

Cada Módulo será dado em um período de quatro horas, abrangendo aula teórica $(\mathrm{T})$ e prática $(\mathrm{P})$ por período. Assim sendo, em todos os períodos serão ministradas aulas práticas.

Na aula prática, em ambos os Módulos, os alunos deverão analisar as estruturas e representá-las por meio de desenhos e descrições. Esta sistemática ajudará não só a desenvolver a capacidade de observação de cada um, mas também a de diagnosticar essas características.

\section{b. Projeto}

O aluno deverá desenvolver um trabalho teórico-prático (T) em grupo de cinco alunos, empregando as metodologias e informações adquiridas durante o curso.

A apresentação do Projeto ocorrerá no final do Curso (vide cronograma), através de data show. Este deverá conter: introdução, material e métodos, resultados, discussão e referências bibliográficas.

A execução do Projeto dar-se-á em horários indicados no cronograma, mas também em datas fora do cronograma a serem acordadas com os alunos.

O Projeto versará sobre a análise morfológica dos órgãos vegetativos e reprodutivos e análise anatômica dos órgãos vegetativos de um material botânico modelo, que será indicado a cada grupo.

\footnotetext{
Rua do Matão - Travessa 14 no. 321 - CEP 05508-900 - Cidade Universitária São Paulo - Brasil - http://www.ib.usp.br
} 


\section{ANEXO G - PROGRAMA DA DISCIPLINA ANATOMIA E MORFOLOGIA DE PLANTAS VASCULARES (CONTINUAÇÃO)

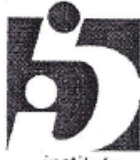 \\ UNIVERSIDADE DE SÃO PAULO \\ INSTITUTO DE BIOCIÊNCIAS \\ DEPARTAMENTO DE BOTÂNICA}

instituto
BIB-121 - Morfologia e Anatomia de Plantas Vasculares 2004

\section{c. Excursão}

Durante o curso será feita uma excursão com atividades de coleta e observação de morfologia externa e interna, além da análise das formas de vida na natureza. O aluno deverá anotar as observações em um roteiro de atividades. Ao final do mesmo dia da excursão será realizada uma discussão final, visando resgatar os principais conceitos pertinentes ao curso.

\section{AVALIAÇÃO}

A avaliação será a média aritmética das notas obtidas nos Módulos I e II. Serão consideradas as notas das provas teóricas (PT), provas práticas (PP) e do trabalho - projeto $(\mathrm{T})$.

As notas do curso serão obtidas da seguinte forma:

$$
\begin{aligned}
& \text { Nota Módulo I }- \text { Morfologia }(\mathrm{NM})=\frac{\mathrm{PT}_{1}+\mathrm{PP}_{1}+\mathrm{PT}_{2}+\mathrm{PP}_{2}+\mathrm{T}}{5} \\
& \text { Nota Módulo II }- \text { Anatomia }(\mathrm{NA})=\frac{\mathrm{PT}_{1}+\mathrm{PP}_{1}+\mathrm{PT}_{2}+\mathrm{PP}_{2}+\mathrm{T}}{5}
\end{aligned}
$$

$$
\text { Nota Final }(N F)=\frac{N M+N A}{2}
$$

A nota do projeto será composta por: a) avaliação da apresentação oral, com a participação de todos: b) avaliação do trabalho elaborado em data show; c) uma questão relativa ao trabalho na última prova leúrica.

\section{MATERIAL PARA AULA PRÁTICA}

O aluno deverá ter para as aulas práticas os seguintes materiais:

a) 1 Pinça histológica de ponta fina

b) 2 Pincéis de pêlo de marta (marca Tigre 266, por exemplo)

c) 2 Estiletes de ponta fina (palito oriental com agulha espetada, por exemplo)

d) 1 Caixa de lâminas de barbear

e) 1 Pano macio (tergal ou fralda velha)

f) 1 Lápis $n^{\circ}$. 2, HB ou F ou lapiseira com grafite desta dureza

g) 1 Borracha mole para desenho 


\section{ANEXO G - PROGRAMA DA DISCIPLINA ANATOMIA E MORFOLOGIA DE PLANTAS VASCULARES (CONCLUSÃO)}

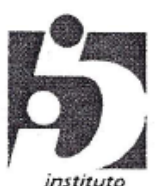

instituto
de biociências

\section{UNIVERSIDADE DE SÃO PAULO \\ INSTITUTO DE BIOCIÊNCIAS DEPARTAMENTO DE BOTÂNICA}

BIB-121 - Morfologia e Anatomia de Plantas Vasculares 2004

h) 1 Caderno para desenho

i) 1 Avental

O aluno deverá trazer para a próxima aula:

a) Frascos de conserva incolores e de boca larga (diferentes tamanhos)

b) Frascos de medicamentos incolores e de boca larga (diferentes tamanhos)

c) Bandejas de isopor

\section{BIBLIOGRAFIA BÁSICA}

ESAU, K. 1960. Anatomia das Plantas com Sementes. Trad. B.L. Morretes, Editora. Blücher, São Paulo.

RAVEN, P.H., EVERT, R.F. \& EICHHORN, S.E. 1992. Biology of Plants, $5^{\text {a }}$. ed. Worth Publishers, New York.

RAVEN, P.H., EVERT, R.F. \& EICHHORN, S.E. 1996. Biologia Vegetal, $5^{\text {a }}$. ed. Coord. Trad. J.E.Kraus. Editora Guanabara Koogan, Rio de Janeiro.

RAVEN, P.H., EVERT, R.F. \& EICHHORN, S.E. 1999. Biology of Plants, 6 a . ed. Worth Publishers, New York.

RAVEN, P.H., EVERT, R.F. \& EICHHORN, S.E. 2001. Biologia Vegetal, $6^{a}$. ed. Coord. Trad. J.E. Kraus. Editora Guanabara Koogan, Rio de Janeiro.

\section{BIBLIOGRAFIA COMPLEMENTAR}

BELL, A.D. 1991. Plant form: na ilustrated guide to flowering plant morphology. Oxford University Press, Oxford.

BOLD, H.C. 1967. Morphology of Plants. Harper \& Row. New York.

ENDRESS, P.R. 1996. Diversity and evolutionary biology of tropical flowers. Cambridge University Press, Cambridge.

ESAU, K. 1977. Anatomy of Seed Plants. $2^{a}$. ed. John Willey \& Sons, New York.

FONT QUER, P. 1965. Diccionario de Botánica. Editorial Labor, Barcelona.

MAUSETH, J.D. 1988. Plant Anatomy. Benjamin \& Cummings, Menlo Park.

MAUSETH, J.D. 1991. Botany: An Introduction to Plant Biology. Saunders College, San Francisco.

RADFORD, E.M. 1974. Vascular Plant Systematics. Harper \& Row, New York.

WEBERLING, F. 1989. Morphology of flowers and inflorescences, Cambridge University Press, Cambridge.

\section{SITES DE INTERESSE NA INTERNET}

http://atlasveg.ib.usp.br

http://dallas.tamu.edu/Weeds/anat.html

http://bugs.bio.usyd.edu.au/2003A+Pmodules/home.html

Livro de P. Raven 1999 - http://www.whfreeman.com/raven/

Livro do Mauseth 1988 - http://www.esb.utexas.edu/mauseth/weblab/ 


\section{ANEXO H - CRONOGRAMA DA DISCIPLINA ANATOMIA E MORFOLOGIA DE PLANTAS VASCULARES}

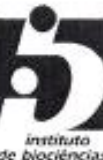

UNIVERSIDADE DE SÃO PAULO

BIB 121 - MORFOLOGIA E ANATOMIA DE PLANTAS VASCULARES - 2007 CRONOGRAMA: PERIODO INTEGRAL

\begin{tabular}{|c|c|c|c|c|c|}
\hline QUA & & MORFOLOGIA & QUA & & ANATOMIA \\
\hline DATA & AULA & CONTEUDDO & DATA & AULA & CONTEUDO \\
\hline $07 / 03$ & $\mathrm{~T} / \mathrm{P}$ & $\begin{array}{l}\text { Conquista do ambiente terrestre / } \\
\text { Diversidade e caracteristicas basicas dos } \\
\text { orgãos }\end{array}$ & $07 / 03$ & T/P & Unidade dos tecidos / Microtécnica \\
\hline $14 / 03$ & $\mathrm{~T} / \mathrm{P}$ & Semente, germinação e plåntula & $14 / 03$ & $\mathrm{~T} / \mathrm{P}$ & Meristemas \\
\hline $21 / 03$ & $\mathrm{~T} / \mathrm{P}$ & Anatomia: Tecidos fundamentais & $21 / 03$ & T/P & Anatomia: Sistema de condução \\
\hline $28 / 03$ & T/P & Raiz & $28 / 03$ & T/P & Raiz: estrutura primária e secundária \\
\hline $11 / 04$ & $\mathrm{~T} / \mathrm{P}$ & Caule & $11 \% 04$ & T/P & Caule: ontogênesc e estrutura primária \\
\hline $18: 04$ & $\mathrm{~T} / \mathrm{P}$ & Arquitetura vegetal; formas de vida & $18 / 04$ & TPP & Caule: estrutura secundária \\
\hline $21 / 04$ & Sábado & Excursão: Serra da Cantareira & & & \\
\hline $25 / 04$ & $T / P$ & Folha & $19 / 04$ & T/P & Folha \\
\hline $02 / 05$ & & PROJETO & $02 / 05$ & & PROJETO \\
\hline $09 / 05$ & & AVALIAÇĀO & 09,05 & & AVALIAÇÃO \\
\hline $16 / 05$ & $\mathrm{~T} / \mathrm{P}$ & Estruturas reprodutivas: Estróbilo & $16 / 05$ & $\mathrm{~T} / \mathrm{P}$ & Estróbilo: Esporogẻnese e Gametogènese \\
\hline $23 / 05$ & $T / P$ & Flor & $23 / 05$ & $\mathrm{P}$ & Morfologia: Flon' Projeto \\
\hline 30,05 & $\mathrm{~T} / \mathrm{P}$ & Inflorescéncia & 30,05 & $\mathrm{~T} / \mathrm{P}$ & Angiosperma:esporogênese e gametogênese \\
\hline $06 / 06$ & $\mathrm{~T} / \mathrm{P}$ & Polinizaçĩo & $06 / 06$ & $\mathrm{~T} / \mathrm{P}$ & Morfologia: Fruto \\
\hline 13,06 & $\mathrm{~T} / \mathrm{P}$ & Dispersão & $13 / 06$ & T/P & Morfologia \& Anatomia: Semente \\
\hline $20 / 06$ & & APRESENTAC̄ĀO PROJETO & 20,06 & & APRESENTACCAOO PROJETO \\
\hline $27 / 06$ & & AVALIAÇÁO & $27 / 06$ & & AVALIACĀO \\
\hline
\end{tabular}

Rua do Matão - Travessa 14 no. 321 - CEP 05508-900 - Cidade Universitária Săo Paulo - Brasil - http:I/www.ib.usp.br 
ANEXO I - PROVA OBJETIVA DE BIOLOGIA DA FUVEST/2006

\section{BIOLOGIA}

89 Assinale a alternativa que, no quadro abaixo, indica os compartimentos celulares em que ocorrem a sintese de RNA e a sintese de proteinas „ em animais e em bactérias.

\begin{tabular}{|l|l|l|l|l|}
\cline { 2 - 5 } \multicolumn{1}{c|}{} & \multicolumn{2}{c|}{ Animais } & \multicolumn{2}{c|}{ Bactérias } \\
\cline { 2 - 5 } \multicolumn{1}{c|}{$\begin{array}{c}\text { sintese de } \\
\text { RNA }\end{array}$} & $\begin{array}{l}\text { síntese de } \\
\text { proteinas }\end{array}$ & $\begin{array}{l}\text { sintese de } \\
\text { RNA }\end{array}$ & $\begin{array}{l}\text { síntese de } \\
\text { proteinas }\end{array}$ \\
\hline a) & núcleo & citoplasma & núcleo & citoplasma \\
\hline b) & núcleo & núcleo & citoplasma & citoplasma \\
\hline c) & núcleo & citoplasma & citoplasma & citoplasma \\
\hline d) & citoplasma & núcleo & citoplasma & núcleo \\
\hline e) & citoplasma & citoplasma & citoplasma & citoplasma \\
\hline
\end{tabular}

$90 \mathrm{Um}$ individuo ể heterozigótico em dois locos: $A a B b$. Um espermatócito desse individuo sofre meiose Simultaneamente, uma célula sangưinea do mesmo individuo entra em divisắo mitótica. Â final da interfase que precede a meiose e a mitose, cada uma dessas células teră respectivamente, a seguinte constituiçẩo genética:
a) $A a B b$ e $A a B b$
b) $A a B b$ e $A A a a B B b b$
c) $A A a a B B b b$ e $A a B b$
d) $A A a a B B b b$ e $A A a a B B b b$
e) $A B$ e $A a B b$

$91 \mathrm{Um}$ deferminado tipo de proteina presente em praticamente todos os animais, ocorre em três formas diferentes: a forma $P_{1}$ a forma $P X$ resultante de mutaçẩo no gene que codifica $\mathrm{P}_{\mathrm{D}}$ e a forma $\mathrm{PY}$, resultante de mutaçăo no gene que codifica PX.

A ocorrência dessas mutaçőes pôde ser localizada nos pontos indicados pelos retângulos escuros na ârvore filogenética, com base na forma da proteina presente nos grupos de animais $\left\|_{\mathbb{1}}\right\|_{\mathbb{m}} \|_{\mathrm{I}} \mathrm{IV}$ eV

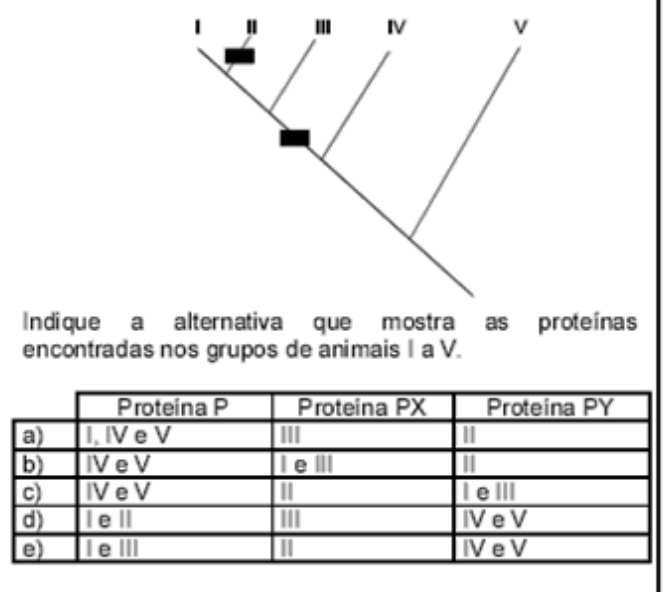

92 o ciclo de vida de uma planta de feilăo pode ser representado pelo esquema abaixo?

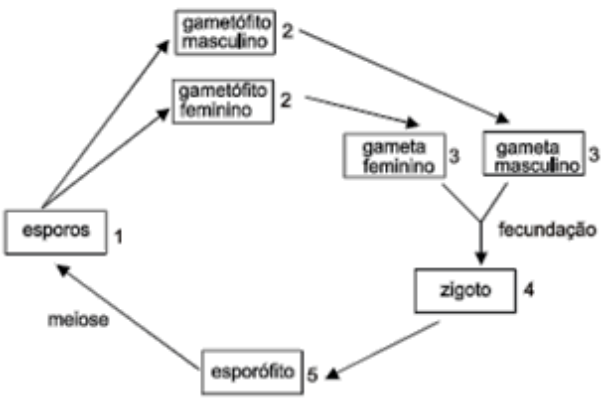

Um conjunto haplóide de genes é encontrado em cêlulas do

a) embriåo que se forma a partí de 4 .

b) endosperma que se forma em 1 .

c) endosperma que se forma em 5 .

d) tubo polinico que se forma em

e) tubo polinico que se forma em 5

93 As angiospermas se distinguem de todas as outras plantas pelo fato de apresentarem

a) altemăncia de geraçăo hapiơide e diplóbide.

b) estồmatos nas folhas.

c) flores.

d) sementes

e) vasos condutores de seiva.

94 Qual das altemativas relaciona corretamente cada um dos animais designados pelas letras de $\mathrm{A}$ a $\mathrm{D}$ com as caracteristicas indicadas pelos nûmeros de la IV?

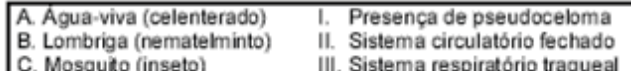
$\begin{array}{ll}\text { C. Mosquito (inseto) } & \text { III. Sistema respiratorio traqueal }\end{array}$ D. Sapo (anfibio) $\quad$ IV. Sistema digestorio incompleto
a) $\mathrm{A}=\mathrm{B} \quad \mathrm{B}-\mathrm{V} \quad \mathrm{C}-\| \mathrm{I}$ D-\|II.
b) $A=11$ B-II $C-\|$ III $D-N$

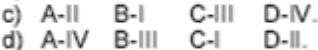
e) $\mathrm{A}-\mathrm{IV} \quad \mathrm{B}-\|$ C-III $\mathrm{D}-\mathrm{II}$

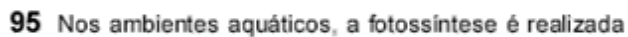
principalmente por

a) algas e bactêrias.

b) algas e plantas.

c) algas e fungos.

d) bactęrias e fungos.

e) fungos e plantas. 


\section{ANEXO J - PROVA DISSERTATIVA DE BIOLOGIA DA FUVEST/2006}

\section{Q.05}

A polinização é um evento essencial para a produção de frutos nas plantas. Em algumas espécies, no entanto, pode haver formação de frutos na ausência de polinização, se as flores forem pulverizadas com certos hormônios vegetais

a) Que parte da flor é estimulada pelos hormônios a se desenvolver em fruto?

b) Qual é a diferença entre um fruto gerado pela aplicação de hormônios, sem que haja polinização, e um fruto resultante da polinização?

\section{Q.06}

O gráfico a seguir mostra, em unidades arbitrárias, as quantidades de gás carbônico $\left(\mathrm{CO}_{2}\right)$ liberadas e absorvidas por uma planta em diferentes intensidades luminosas.

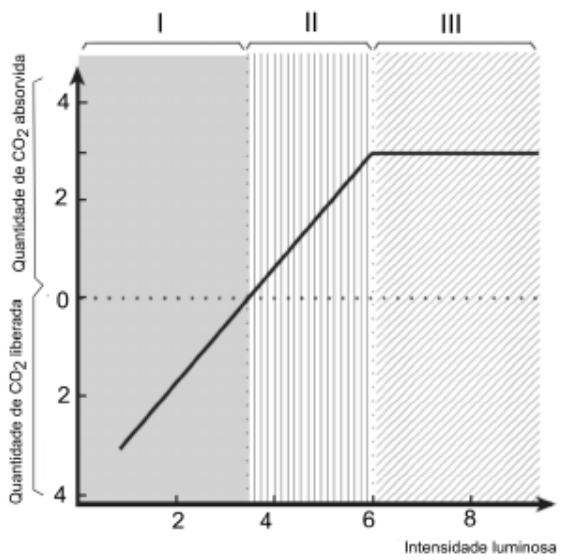

Indique as faixas de intensidades luminosas (I, II, III) em que

a) ocorre aumento da quantidade de matéria orgânica na planta. Justifique.

b) a planta absorve gás oxigênio do ambiente. Justifique. 